\title{
A SYK/CARD9 SZIGNALIZÁCIÓ SZEREPE A CANDIDA PARAPSILOSIS IMMUNOLÓGIAI FELISMERÉSÉBEN
}

DOKTORI ÉRTEKEZÉS

ZAJTA ERIK

TÉMAVEZETŐ:

PROF. DR. GÁCSER ATTILA

EGYETEMI TANÁR

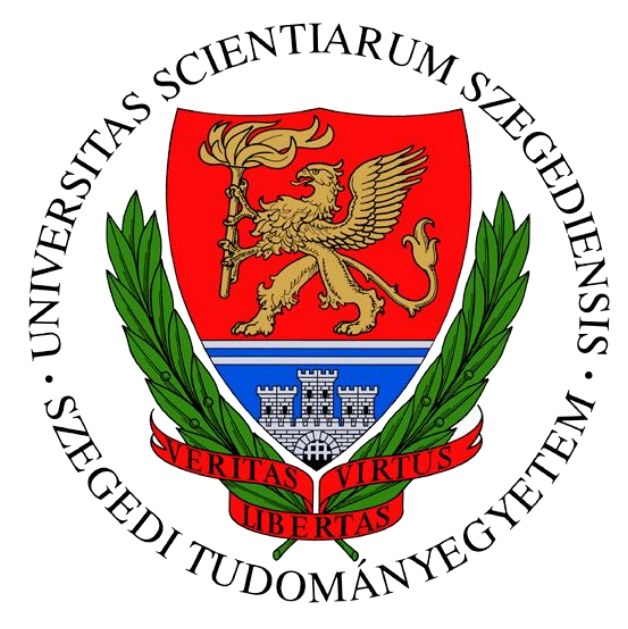

SZEGEDI TUDOMÁNYEGYETEM

TERMÉSZETTUDOMÁNYI ÉS INFORMATIKAI KAR

MIKROBIOLÓGIAI TANSZÉK

SZEGED 


\section{Tartalomjegyzék}

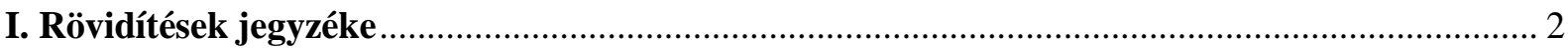

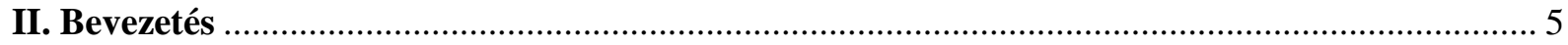

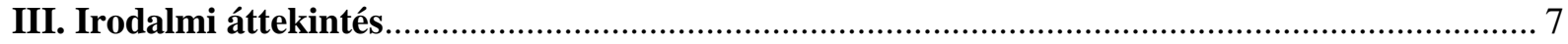

III.1. Gombák által okozott megbetegedések ........................................................................... 7

III.2. A Candida nemzetség és a Candida parapsilosis (Ashford) Langeron \& Talice 1932 jellemzése

III.2.1. A Candida nemzetség és a Candida parapsilosis taxonómiai, filogenetikai és morfológiai jellemői

III.2.2. A Candida nemzetség és a Candida parapsilosis genetikai jellemzői ............................... 9

III.2.3. A Candida nemzetség és a Candida parapsilosis ökológiai jellemzői ............................. 10

III.2.4. A Candida spp. és a Candida parapsilosis által okozott kórképek .................................... 11

III.2.5. A humánpatogén Candida fajok és a Candida parapsilosis virulencia faktorai ................ 11

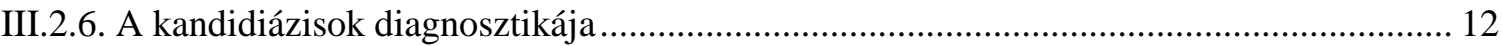

III.2.7. A kórokozó Candida fajok és a Candida parapsilosis által okozott betegségek terápiája,

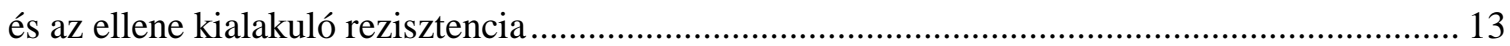

III.2.8. Az invazív kandidiázisok epidemiológiája ........................................................................ 14

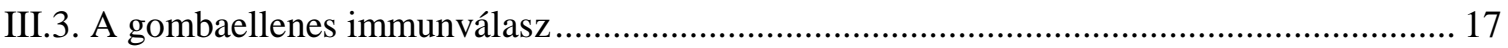

III.3.1. Az antifungális veleszületett immunitás általános sémája............................................... 17

III.3.2. Az antifungális veleszületett immunitás sejtes elemei ..................................................... 18

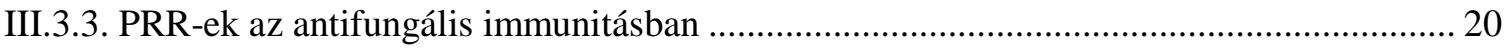

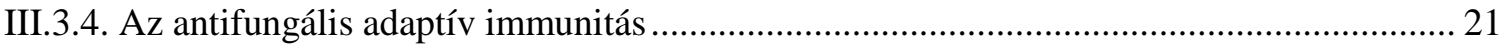

III.3.5. A Syk és CARD9 a gombák veleszületett immunrendszer általi érzékelésében ................ 22

III.3.6. A Syk és CARD9 szerepe az anti-Candida immunitásban ................................................ 26

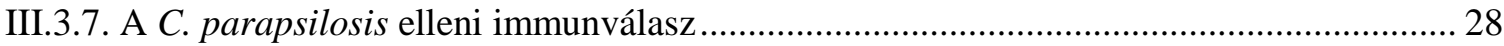

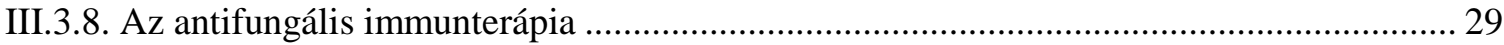

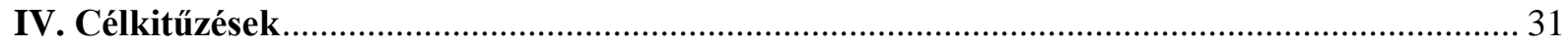

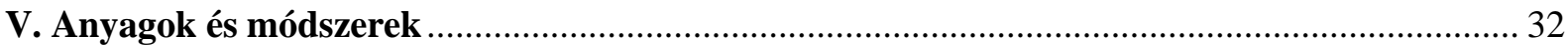

V.1. Táptalajok, tápoldatok, pufferek és egyéb reagensek ............................................................. 32

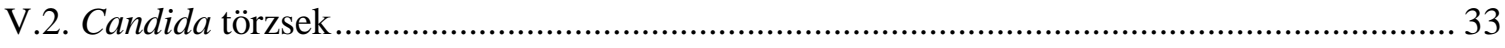

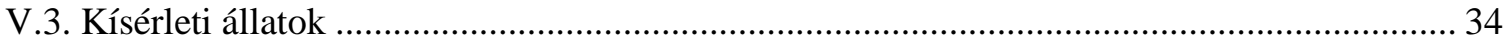

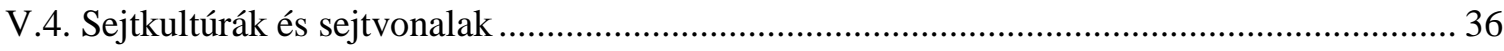

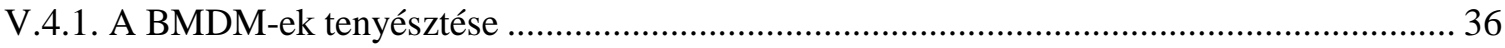




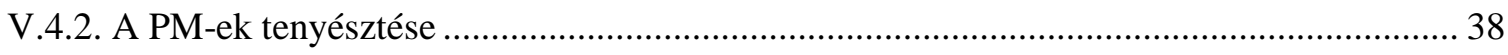

V.4.3. Az L929 sejtvonal és az L929 kondicionált médium .......................................................... 38

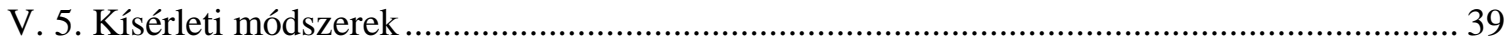

V.5.1. A makrofágok tenyésztési módszerének ellenőrzése ........................................................... 39

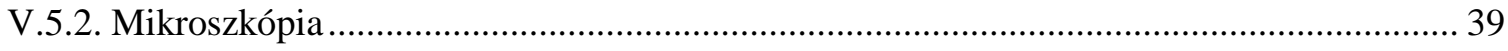

V.5.3. A makrofágok és Candida sejtek koinkubációja (fertőzés) ................................................... 41

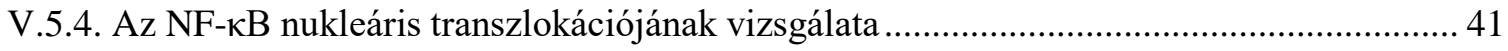

V.5.5. Citokinprofil vizsgálata Proteome Profiler segítségével ..................................................... 42

V.5.6. Citokinek mennyiségi meghatározása enzimkötött immunoszorbens próba (ELISA)

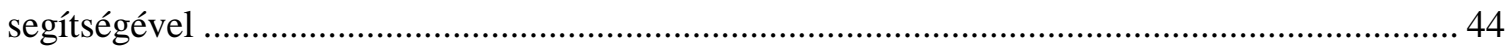

V.5.7. A Candida sejtek makrofágok általi fagocitózisának vizsgálata .......................................... 44

V.5.8. Élesztősejtet tartalmazó fagoszómák savasodásának vizsgálata makrofágokban .............. 45

V.5.9. A C. parapsilosis makrofágok általi eliminációjának vizsgálata ........................................... 47

V.5.10. Gombakolonizáció mértékének meghatározása különböző szövetekből CFU

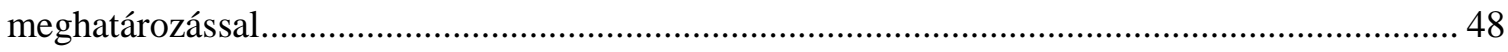

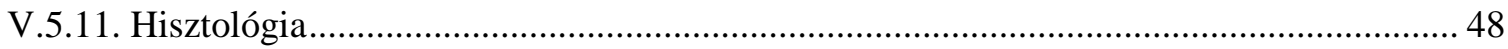

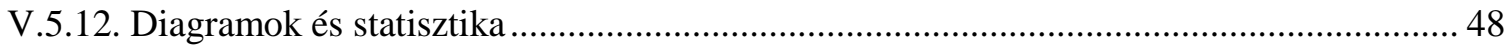

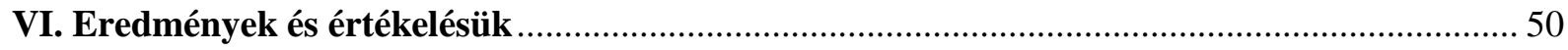

VI.1. Az NF-kB nukleáris transzlokációja Syk- és CARD9-függő a C. parapsilosisszal fertőzött

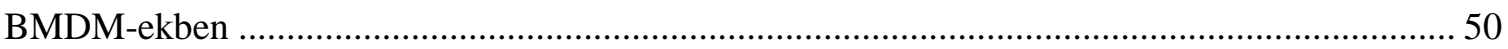

VI.2. Az egér makrofágok $C$. parapsilosis fertőzés során kiváltott citokinválasza a Syk és a

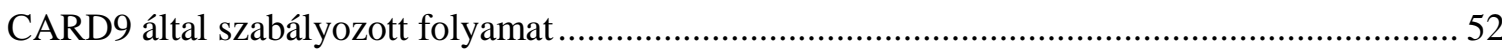

VI.3. A C. parapsilosis és a C. albicans egér makrofágok általi fagocitózisa a Syk szabályozása alatt áll

VI.4. A C. parapsilosis tartalmú fagoszómák savasodása függ a Syktől, de a CARD9-től nem .. 62

VI.5. A C. parapsilosis BMDM-ek általi eliminációja Syk-függő, de CARD9-független 63

VI.6. A Syk/CARD9 jelátvitel hozzájárul a szisztémás $C$. parapsilosis fertőzés során kialakuló

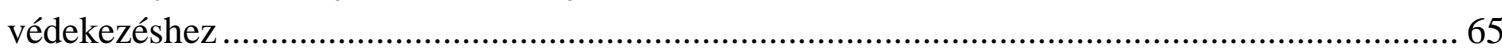

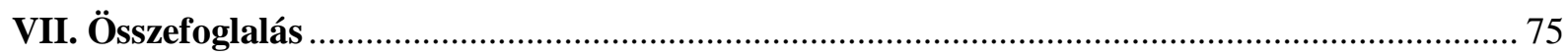

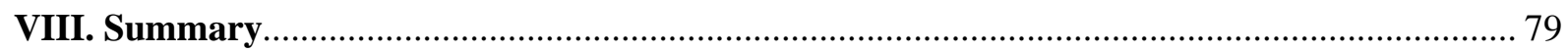

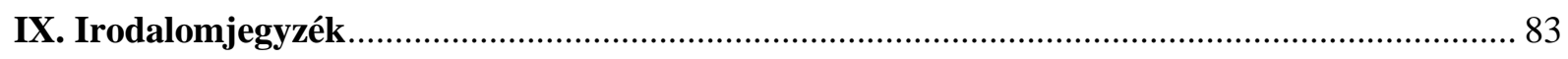

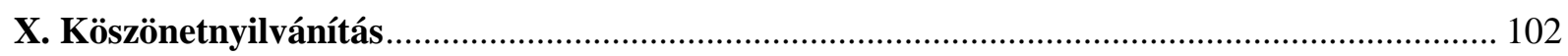

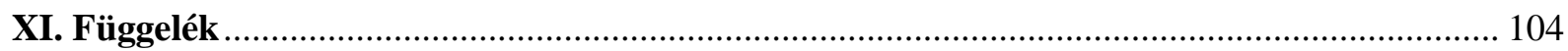




\section{Rövidítések jegyzéke}

AIDS: acquired inmmune deficiency syndrome (szerzett immunhiányos tünetegyüttes)

AMP: antimikrobiális peptid

BMDM: $\underline{b}$ one marrow derived macrophage (csontvelőből differenciáltatott makrofág)

BSA: bovine serum albumin (marha szérum albumin)

CARD9: caspase recruitment domain-containing protein $\underline{9}$ (kaszpáz toborzó domén tartalmú fehérje 9)

CFU: colony-forming unit (telepképző egység)

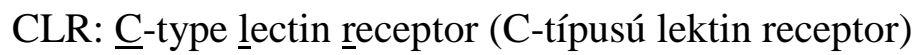

CMC: chhronic mucocutaneous candidiasis (krónikus mukokután kandidiázis)

DMEM: Dulbecco's modified Eagle’s medium (Dulbecco által módosított Eagle-féle tápoldat)

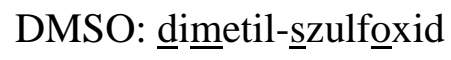

ELISA: enzyme-linked ịmmunosorbent assay (enzimkötött immunoszorbens próba)

FBS: fetal bovine serum (fetális borjú szérum)

GFP: green fluorescent protein (zöld fluoreszcens protein)

GM-CSF: granulocyte-macrophage colony-stimulating factor (granulocita-makrofág kolónia stimuláló faktor)

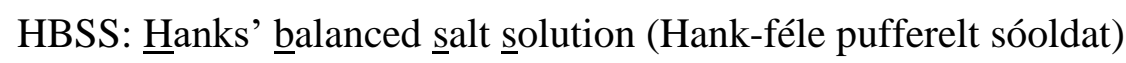

HE: hematoxilin eozin

IFN- $\gamma$ : interferon- $-\underline{ }$

IL-: interleukin-

ITAM: immunoreceptor tirozin-alapú aktivációs motívum

KC: keratinocyte chemoattractant (keratinocita kemoattraktáns)

LPS: lipopolysaccharide (lipopoliszacharid)

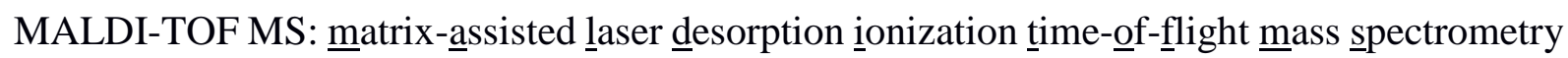
(mátrix-asszisztált lézer deszorpciós, ionizációs, repülési idő mérésén alapuló tömegspektrometria)

M-CSF: macrophage-colony știmulationg factor (makrofág kolóniastimuláló faktor)

MIP-: macrophage inflammatory protein- (makrofág gyulladásos fehérje-)

MOI: multiplicity of infection (fertőzési arányszám)

MTL: mating-type loci (párosodási típus lókuszok)

NF- $\kappa B$ : Nuclear Factor- $\underline{\kappa B}$ (nukleáris faktor- $\kappa B$ ) 


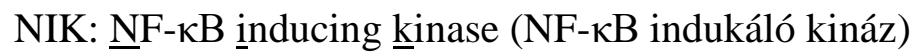

NK: natutal killer (természetes ölősejt)

NLR: NOD-like receptor (NOD-szerü receptor)

PAMP: pathogen associated molecular pattern (patogén asszociált molekuláris mintázat)

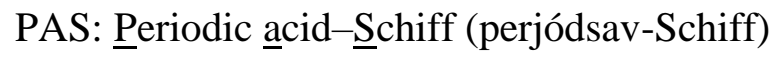

PBS: phosphate buffered saline (foszfát pufferes sóoldat)

PE: phycoerythrin (fikoeritrin)

PFA: paraformaldehid

PM: peritoneal macrophage (peritoneális makrofág)

PRR: pattern recognition receptor (mintázatfelismerő receptor)

SCID: severe combined îmmunodeficient (súlyos kombinált immunhiányos)

spp.: species pluralis (fajok)

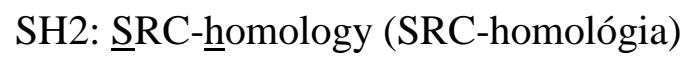

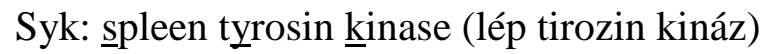

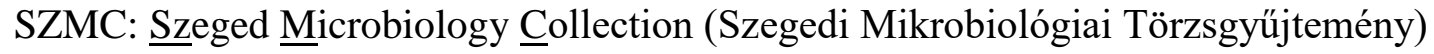

SZTE: Szegedi Tudományegyetem

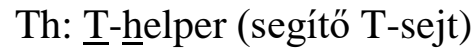

TLR: toll-like receptor (toll-szerü receptor)

TNFa: tumor necrosis factor alpha (tumor nekrózis faktor alfa)

$\mathrm{T}_{\text {reg: }}$ regulatory $\underline{\mathrm{T}}$-cell (regulátor T-sejt)

Vt: a típus

Wt: wild type (vad típus)

YPD: yeast extract-peptone-dextrose (élesztőkivonat pepton dextróz) 


\section{Bevezetés}

A gombák által okozott fertőzések komoly egészségügyi problémát jelentenek világszerte. Közülük különösen az invazív fertőzések jelentősége növekszik, mivel ezek esetszáma az utóbbi évtizedekben jelentős emelkedést mutat, és gyógyszeres kezelés mellett is gyakran halálos kimenetelüek. Kialakulásuk főleg az immunrendszer elégtelen müködéséhez kötött, így leggyakrabban opportunista patogének okozzák. Közülük kiemelkedőek a Candida nemzetség egyes fajai (Brown és mtsai. 2012, Bongomin és mtsi 2017).

Az invazív Candida fertőzések mortalitása meghaladhatja az 50\%-ot (Brown és mtsai. 2012). Az ilyen fertőzések során leggyakrabban azonosított faj a C. albicans, azonban az utóbbi években egyre növekszik az ún. non-albicans fajok előfordulása. Ide tartozik a C. parapsilosis is, amely a nemzetség képviselői közül a második vagy harmadik legnagyobb gyakorisággal okoz invazív megbetegedéseket és elsősorban az újszülötteket, a koraszülötteket vagy az alacsony testsúllyal született csecsemőket veszélyezteti (Tóth és mtsai. 2019).

Mivel az antifungális szerek alkalmazása a súlyos gombás fertőzések gyógyításában nem kielégítő hatékonyságú, sürgető az újabb kezelési módszerek kifejlesztése. Ezek egyike lehet a gombaellenes immunterápia, amely a gazdaszervezet immunológiai folyamatainak modulációján keresztül segíti elő a gyógyulást (Armstrong-James és Harrison 2012). Ennek feltétele a gombaellenes immunválasz részletes megismerése. Az emberi immunrendszer különböző receptorok segítségével ismeri fel a patogén gombákat, ami azután különböző szignáltranszdukciós utakon keresztül vezet a veleszületett és adaptív immunválasz kialakulásához (Salazar és Brown 2018). Mivel ezek a válaszok akár az azonos nemzetségbe tartozó kórokozó gombák esetén is eltérőek lehetnek, faji szinten történő feltárásukra is igény van (Patin és mtsai. 2016).

A lép tirozin kináz (slpeen tyrosine kinase, Syk) és Caspase Recruitment Domain Containing Protein $\underline{9}$ (CARD9) jelátviteli komponensek számos folyamat szabályozása révén fokozhatják az antifungális effektor folyamatokat (Salazar és Brown 2018). Szerepük alapvető a C. albicansszal szembeni immunitásban (Deng és mtsai. 2015, Drummond és mtsai. 2018), azonban a $C$. parapsilosisszal kapcsolatban jelentőségük alig ismert.

Munkánk célja volt kideríteni, hogy a Syk és CARD9 milyen szerepet töltenek be $C$. parapsilosis okozta fertőzés során. Elöször makrofágokkal végzett in vitro kísérletek segítségével vizsgáltuk ezen fehérjék hozzájárulását a $C$. parapsilosis immunológiai felismeréséhez és a gomba ellen kialakuló egyes sejtbiológiai folyamatokhoz. Később in vivo 
invazív fertőzési modellben teszteltük érintettségüket a $C$. parapsilosis elleni szervezetszintü védelemben. Összehasonlításképpen a kísérletek többségét a $C$. albicans felhasználásával is elvégeztük. 


\section{Irodalmi áttekintés}

\section{III.1. Gombák által okozott megbetegedések}

Az emberek többsége élete során legalább egyszer szenved gombás fertőzéstől (Brown és mtsai. 2012). Ez leggyakrabban a bőrt vagy nyálkahártyákat érintő mikózis, azonban a kórokozó elterjedhet a szervezetben, és az így kialakuló invazív betegség során megtörténik a belső szervek gomba általi kolonizációja (Dismukes és mtsai. 2003). A humánpatogén gombák egy része valódi patogén, azaz egészséges egyénekben is okozhat megbetegedést, más részük viszont opportunista, így csak a gazdaszervezet valamilyen kedvezötlen állapota (pl. cukorbetegség, legyengült immunrendszer) esetén képes erre (Köhler és mtsai. 2017).

A bőrt érintő fertőzések a leggyakoribb gombás betegségek, a Föld népességének körülbelül negyede érintett (Brown és mtsai. 2012). Hazánkban is elterjedtek (Szodoray és mtsai. 1957, Stefándel 1984, Halmy 1997), éves számukat Magyarországon 1410000-re becsülték (Sinkó és mtsai. 2015).

Szintén elterjedtek a nyálkahártyák fertőzései, melyek évente kb. 100 millió embert érintenek (Gow és Netea 2016). Ide tartozik a sarjadzógomba eredetű vulvovaginitisz, amelytől a legtöbb nő élete során legalább egyszer szenved, továbbá évi közel 75 millió nő megy keresztül ezen betegség legalább négy epizódján (Brown és mtsai. 2012). Hazánkban a visszatérő vulvovaginális kandidiázisban (Candida fertőzésben) szenvedők számát évente 177000-re becsülték (Sinkó és mtsai. 2015).

Invazív gombás megbetegedések az előbbiekkel ellentétben ritkábban fordulnak elő, azonban ezek gyógyszeres kezelés mellett is életveszélyes állapotokat idézhetnek elő. Évente 1,5 millió ember halálát okozzák az ilyen fertőzések, ami több mint a maláriában vagy mellrákban egy évben elhunytak száma és összevethető a tuberkulózis okozta elhalálozások mennyiségével (Brown és mtsai. 2012, Gow és Netea 2016). Ezen mikózisok egy részét valódi patogének okozzák, mint a hazánkban is kimutatott Coccidioides immitis (Zalatnai és mtsai. 1998). Az invazív mikózisok többségéért azonban opportunista kórokozók felelnek (pl. Cryptococcus, Candida, Aspergillus, Pneumocystis vagy Rhizopus fajok) (Köhler és mtsai. 2017). Az ilyen betegségre hajlamosító állapotok közé tartozik többek között az újszülött és idős kor, a szerzett immunhiányos szindróma (AIDS), az immunrendszer müködésében szerepet játszó gének egyes polimorfizmusai, vagy az orvosilag indukált immunszuppresszált állapotok (pl. kemoterápia/radioterápia során, vagy őssejt-/szervátültetések esetén) (Hof 2009, Brown és mtsai. 2012, Gow és Netea 2016). Egy hazai felmérésben például a hematopoetikus 
őssejt átültetés után bekövetkezett elhalálozások több mint negyedét okozta invazív gombás fertőzés (Sinkó és mtsai. 2008). Becslés szerint Magyarországon a fent említett súlyos vagy életveszélyes gombás fertőzések száma évente 33000 (Sinkó és mtsai. 2015).

A gombák feltételezett fajszáma elérheti a 1,5 milliót (egyes becslések szerint akár az 5 milliót is), azonban csupán néhány száz faj képes embereket megbetegíteni, köztük is kisebbségben vannak a valódi patogének (Köhler és mtsai. 2014, Köhler és mtsai. 2017). Spatafora és mtsai. (2017) rendszere szerint emberi kórokozó gombák a valódi gombák Microsporidia, Zoopagomycota, Mucormycota, Basidiomycota és Ascomycota törzseiben fordulnak elö, melyekből az Ascomycota (tömlősgombák) tartalmazza a legtöbbet (Taylor 2014). Az ide sorolt Aspergillus, Pneumocystis és Candida fajok a legjelentősebbek közé tartoznak, mivel a bazídiumos Cryptococcus fajokkal együtt a gombás fertőzésekből adódó elhalálozások több mint 90\%-át ezen négy nemzetség képviselői okozzák (Brown és mtsai. 2012).

\section{III.2. A Candida nemzetség és a Candida parapsilosis (Ashford) Langeron \& Talice 1932 jellemzése}

\section{III.2.1. A Candida nemzetség és a Candida parapsilosis taxonómiai, filogenetikai és morfológiai jellemzői}

A Candida nemzetség opportunista patogén fajai a leglényegesebb emberi kórokozó gombák közé tartoznak, mivel az invazív mikózisok leggyakoribb etiológiai ágensei súlyosan immunkompromittált emberekben, invazív klinikai beavatkozáson átesett betegekben, vagy olyan súlyos traumás sérülést elszenvedett egyénekben, akiket hosszabb ideig intenzív osztályon ápolnak (Brown és mtsai. 2012). A csoport egyik kiemelt klinikai jelentőségü képviselöje a C. parapsilosis (Trofa és mtsai. 2008).

A Candida nemzetség a tömlösgombák között a Saccharomycotina altörzs Saccharomycetes osztályán belül a Saccharomycetales rendbe tartozik, ahová 150 fajt sorolnak (Köhler és mtsai. 2017). A génusz nem monofiletikus (Fitzpatrick és mtsai. 2006, Holland és mtsai. 2014, Köhler és mtsai. 2014), és a renden belüli további besorolása még nem tisztázott (Saccharomycetales incertae sedis) (Kurtzman és Fell 2006, McManus és Coleman 2014). Több orvosi jelentőségü Candida faj az ún. CUG kládba tartozik. Erre a csoportra jellemző, hogy képviselőiben a CUG kodon a fehérjék bioszintézise során nem leucinre, hanem szerinre fordítódik le (Turner és Butler 2014, Holland és mtsai. 2014). Ide sorolják a $C$. parapsilosist is. Ezt a fajt első alkalommal 1928-ban izolálták humán székletéből Puerto Ricóban. Először Monilia parapsilosis néven írták le (Ashford 1928, Trofa és mtsai. 2008), 
majd a Candida nemzetségbe sorolták át (Langeron és Talice 1932). Később főleg molekuláris genetikai alapon 3 csoportot különböztettek meg a fajon belül (Lin és mtsai. 1995). További multilókuszos genetikai vizsgálatok eredményeként a csoportokat különálló, közeli rokon fajokként írták le. A faj, amelybe a típustörzs tartozott $C$. parapsilosis (sensu stricto) maradt, míg a másik két csoportot Candida orthopsilosis és Candida metapsilosis néven írták le (Tavanti és mtsai. 2005). E három faj közül a $C$. parapsilosis okoz leggyakrabban megbetegedést (Trofa és mtsai. 2008).

A Candida fajok sarjadzógombák. Általában ovoid, kerekded vagy hosszúkás alakú élesztősejtek formájában szerveződnek, melyek multilaterális holoblasztikus sarjadzással osztódnak (Larone 1987, Moris és mtsai. 2008, Cooper 2011, Daniel és mtsai. 2014). Egyes képviselői egyéb morfológiájú képleteket, például pszeudohifákat, valódi hifákat, vastag falú klamidospórákat stb. fejleszthetnek (Silva és mtsai. 2012). A Candida telepek táptalajon általában krémszínűek és sima felületűek, egyes fajoknál a telepek szélein hifák alkotta szegély jelenhet meg (Larone 1987) (1. ábra). A C . parapsilosis sejtjei 2,5-4×2,5-9 $\mu \mathrm{m}$ méretủek, alakjuk kerekded, ovális, vagy orsó alakú. Ez a gomba élesztő vagy pszeudohifa formát vesz fel, valódi hifát nem képez. Sabouraud dextróz vagy YPD táptalajokon fehér vagy világos krémszínű, sima vagy ráncos telepeket alkot (Kim és mtsai. 2006, Trofa és mtsai. 2008).

A Candida sejtek sejtfala fóként a nemzetség legismertebb fajáról, a C. albicansról szerzett ismeretek alapján 3 fö rétegből áll. A plazmamembránhoz legközelebbi réteg kitint tartalmaz, középen föleg $\beta$-D-glükánokból álló réteg található, melyet kívülről magas mannán tartalmú réteg borít. A sejtfalban különböző funkciójú fehérjék (pl. a megtapadást segítő adhezinek) találhatók (Brown és mtsai. 2014, Gow és mtsai. 2017). A sejtfal számos komponense szerepet játszik a gombaellenes immunitás kialakulásában (Netea és mtsai. 2015).

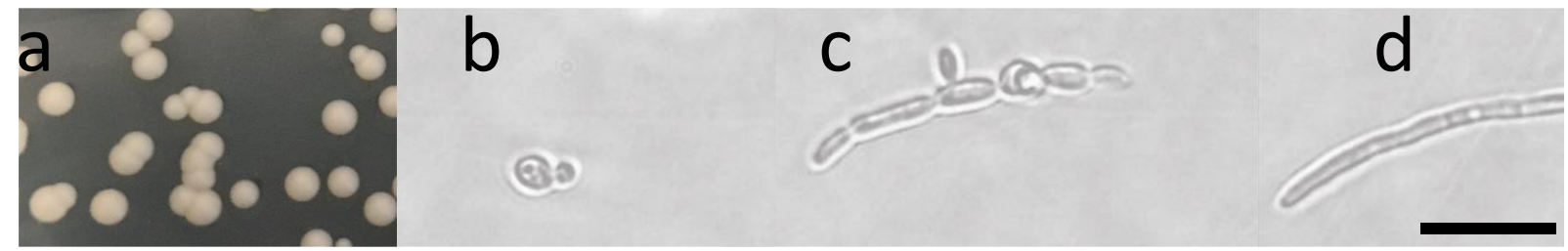

1. ábra. A C. albicans (a) telepei YPD táptalajon és (b-d) humán szövetmintákban is megfigyelhető alakjai YPD tápoldatban: (b) élesztő, (c) pszeudohifa és (d) valódi hifa. Skála: $20 \mu \mathrm{m}$. Saját felvétel.

\section{III.2.2. A Candida nemzetség és a Candida parapsilosis genetikai jellemzői}

A legtöbb humánpatogén Candida esetén nem írtak le valódi szexuális szaporodást, másoknál (pl. C. guilliermondii, C. lusitaniae, Candida krusei) igen (Turner és Butler 2014, 
Chan és mtsai. 2012). A genetikai állomány variabilitásához azonban több faj esetén (pl. $C$. albicans, C. tropicalis) paraszexuális ciklus járulhat hozzá. A nemzetség egyes képviselői diploid (pl. C. tropicalis), mások haploid (pl. C. glabrata) nukleáris genommal rendelkeznek (Cooper 2011, Turner és Butler 2014). Több klinikailag releváns faj (pl. C. guilliermondii, C. lusitaniae, C. albicans, C. tropicalis stb.) magi genomszekvenciája ismert. Ennek mérete $~ 12-$ 16 megabázis pár, a GC tartalom 33-45\% és a fehérjét kódoló gének becsült száma 6000 körüli (Dujon 2010). A C. parapsilosis diploid szervezet. Nukleáris genomja 8 kromoszómapárból áll (Tóth és mtsai. 2019), 13,1 megabázis pár nagyságú, génjeinek száma 5730 (Butler és mtsai. 2009). A teljes genom szekvenciái alapján a kromoszómák között alacsony heterozigozitást mutattak ki (Butler és mtsai. 2009, Pryszcz és mtsai. 2013). Szexuális vagy paraszexuális ciklust ezen fajban nem figyeltek meg (Turner és Butler 2014), azonban párosodási típus lókuszokkal (ㄸating-type loci, MTL) homológ DNS-szakaszokat igen, melyek közül az MTLal egy pszeudogén (Butler és mtsai. 2009, Sai és mtsai. 2011). Pryszcz és mtsai. (2013) különböző izolátumok DNS-szekvenciáiban fellelhető pontmutációk ismeretében arra következtettek, hogy ebben a fajban is létezik valamilyen rekombinációs mechanizmus.

\section{III.2.3. A Candida nemzetség és a Candida parapsilosis ökológiai jellemzői}

A Candida nemzetség kozmopolita, fajai számos élőhelyről izolálhatók, úgymint korhadó fákról, gyümölcsök és egyéb növényi szervek felszínéről, talajból, tengervízből, valamint kommenzalistaként állatok és emberek köztakaróján és bélrendszerében is élhetnek (Odds 1988, Köhler és mtsai. 2014). A C. parapsilosis is széles körben elterjedt a természetben (Trofa és mtsai. 2008). Izolálták különböző állati forrásokból, mint például varacskos disznó bélsárból (Van Uden és Carmo-Sousa 1962), sirály végbélből (Kawakita és Van Uden 1965), vagy beteg belugából (Dunn és mtsai. 1982), továbbá többek között gyümölcs, talaj vagy tengervíz eredetű törzseket is kitenyésztettek (Meyers és mtsai. 1967, Odds 1988, Trofa és mtsai. 2008). A C. parapsilosis az egészséges emberi bőr kommenzalistájaként is ismert (Trofa és mtsai. 2008, Köhler és mtsai. 2017). Egy tanulmányban a vizsgált egyének bőrének 13,9\%áról (Marples és Somerville 1968), egy másik felmérésben 25,6\%-áról (Rafat és mtsai. 2018) tenyészett ki C. parapsilosis törzs. Byrd és mtsai. (2018) az egészséges száraz bőrfelületek 10 leggyakoribb eukarióta kolonizálói között sorolják fel ezt a fajt. Jelenlétét kis gyakorisággal kimutatták az egészséges emberi szervezet különböző nyálkahártyáiról (pl. szájüreg, bél, vagina) is (Odds 1988). 


\section{III.2.4. A Candida spp. és a Candida parapsilosis által okozott kórképek}

A Candida fajok által okozott betegségek típusai a fertőzés helye szerint a következők: (Odds 1988, https://www.fungalinfectiontrust.org/candida-infections):

-Szuperficiális kandidiázosok (felszíni fertőzések):

- Kután kandidiázisok: a bőr betegségei. Ilyenek például a rosszul szellőző bőrkettőzeteken kialakuló kórképek, a Candida eredetű paroníhia (körömágygyulladás) vagy körömgombásodás, illetve a föleg csecsemőket érintő pelenka dermatitisz.

- Nyálkahárya kandidiázis: legismertebb manifesztációi a csecsemők szájpenésze, az AIDS-es betegek esetén gyakori nyelőcső kandidiázis és a nők többségét érintő vulvovaginális kandidiázis.

- Krónikus mukokután kandidiázis (chhronic mucocutaneos candidiasis, CMC): a fertőzés a szájnyálkahártyán kívül bőrfelületeket (pl. arcbőr) is érint, de a körmökön is kialakulhat. Ez a típus nehezen kezelhető, évekig elhúzódhat, és gyakran valamilyen immunológiai defektus következtében alakul ki.

-Invazív kandidiázisok: szinte bármely belső szervre kiterjedhetnek. Okozhatnak például meningitiszt, endokarditiszt, peritonitiszt, hepatitiszt, szplenitiszt stb. Amennyiben a gomba bejut a véráramba (kandidémia), és szétterjedve egyszerre több szervet/szervrendszert is megfertőz, disszeminált vagy szisztémás kandidiázisról beszélünk. Az invazív formák a Candida fertőzések legsúlyosabb típusai, melyek többek között immunszupprimált embereket veszélyeztetnek és gyakran halálos kimenetelüek.

A C. parapsilosis okozta betegségek legismertebb típusai a körömgombásodás, a vulvovaginitisz, az otomikózis (a középfül és a külső fül gombás megbetegedése), a húgyúti fertőzések, a szem fertőzései, az artritisz, a peritonitisz stb. (Trofa és mtsai. 2008).

\section{III.2.5. A humánpatogén Candida fajok és a Candida parapsilosis virulencia faktorai}

A kórokozó Candidákat bizonyos adottságaik segítik fertőzőképességükben, melyeket virulencia faktoroknak nevezünk. Ide tartoznak például a $37^{\circ} \mathrm{C}$-on való szaporodás képessége vagy a biofilmképzés. A különböző gyógyászati eszközökön vagy szövetek felszínén való megtapadásban szerepet játszó adhezin fehérjék, a foszfolipidek bomlását katalizáló foszfolipázok, a gazdaszervezeten belüli lipidek szénforrásként történő hasznosítását és a gyulladásos folyamatok modulálását elősegítő szekretált lipázok, a szöveti károsodást okozó szekretált proteinázok, a hemoglobin bontását végző hemolizinek és a nyomelemek gazdaszervezetből történő felvételét lehetővé tévő speciális vas- és cinkfelvételi rendszerek 
további virulencia faktorok (Silva és mtsai. 2012, Mayer és mtsai. 2013, Gácser 2015, Höfs és mtsai. 2016, Tóth és mtsai. 2017b). A C. albicansban írták le a kandidalizin pórusképző toxin fehérjét, amely többek között epiteliális sejtek károsításában játszik szerepet (Moyes és mtsai. 2016).

A felsoroltak között szerepelnek a $C$. parapsilosis virulencia faktorai is. Ilyenek a gazdasejtek extracelluláris mátrix fehérjéin (Kozik és mtsai. 2015), vagy a szilikon felületeken (Núñez-Beltrán és mtsai. 2017) való megtapadást segítő fehérjék. A C. parapsilosis fertőzések egyik kiemelt rizikófaktora az egyes müanyagból készült orvosilag behelyezett eszközök (pl. centrális vénás kanülök, katéterek, mesterséges szívbillentyük) alkalmazása, mivel ezen gomba biofilmet képezhet ezek felületein. A biofilm forma fokozhatja a C. parapsilosis ellenállóképességét antimikotikumokkal szemben (Katragkou és mtsai. 2008). Az extracelluláris hidrolázok közül a lipázok (Gácser és mtsai. 2007, Tóth és mtsai. 2015, Tóth és mtsai. 2017b) és az aszpartil proteázok (Horváth és mtsai. 2012) szerepét bizonyították a $C$. parapsilosis virulenciájában. Egyes zsírsav és prosztaglandin szintézisért felelős gének (pl. CpFAS1, CpOLE1, CpOLE2, valamint CPFET3, CpPOT1) termékei is befolyásolják ezen gomba fertőzőképességét (Nguyen és mtsai. 2009, Nguyen és mtsai. 2011, Grózer és mtsai. 2015, Chakraborty és mtsai. 2018). A C . parapsilosis HAP5 génjének hiánya mind in vitro, mind in vivo vizsgálatokban csökkent virulenciával járt. A HAP5 feltehetően egyéb gének transzkripcionális szabályozása által szerepet játszik az elérhető vas felvételében és különböző szénforrások hasznosításában (Tóth és mtsai. 2018).

\section{III.2.6. A kandidiázisok diagnosztikája}

Több megközelítést alkalmaznak a kórokozó Candida fajok meghatározására és az általuk okozott betegségek diagnosztikájára. A tenyésztésalapú eljárások közé tartoznak azon biokémiai módszerek, amelyek az élesztők szénhidrát asszimilációs és fermentációs profiljai alapján teszik lehetővé a fajok azonosítását. A C. parapsilosis például a C. albicanstól eltérően nem fermentálja a maltózt (Larone 1987, Cooper 2011). Olyan médiumok (pl. CHROMagar Candida medium) használatakor, amelyek kromogén szubsztrátot tartalmaznak, a legfontosabb humánpatogén Candida fajok telepmorfológia és színreakció alapján különíthetők el (Willinger és Manafi 1999, Willinger és mtsai. 2001, Cooper 2011). A mátrix-asszisztált lézer deszorpciós, ionizációs, repülési idő mérésén alapuló tömegspektrometria (ㄸatrix-âssisted laser desorption ionization time-ôf-flight mass spectrometry, MALDI-TOF MS) alkalmazásával a gombaizolátumokat azok riboszomális fehérjeprofiljai alapján identifikálják (Pulcrano és mtsai. 2013, Nagy és mtsai. 2014). 
Szerológiai módszerekkel lehetőség van bizonyos testnedvekben (pl. vérszérum) Candida eredetủ antigének (pl. mannán) és Candida ellenes antitestek kimutatására (Barton 2018). Szövettani mintákban különböző mikrotechnikai festések (pl. perjódsav-Schiff reakció, Periodic acid- $\underline{\text { Schiff, }}$ PAS) segíthetik a Candida képletek azonosítását, azonban a hisztológiai vizsgálatokban a faji szintü meghatározás gyakran nem lehetséges (Guarner és Brandt 2011).

A különböző Candida fajok modern meghatározását molekuláris biológiai módszerek segítik. Ezek közé tartozik például az RNS fluoreszcens in situ hibridizáció (Kempf és mtsai. 2005), a fajspecifikus polimeráz láncreakció (Beszedics és mtsai. 2008, Asadzadeh és mtsai. 2015) és a DNS szekvenciák (pl. a riboszomális DNS belső átíródó szpészer szakasza) elemzése (Irinyi és mtsai. 2015). A felsorolt módszerek változatossága ellenére a belszervi gombás betegségek diagnózisa még nem megfelelő (Brown és mtsai. 2012). Egy hazai tanulmányban például 10 hematopoetikus őssejt átültetésen átesett egyénből csak négy esetben sikerült az elhalálozás elött diagnosztizálni a mikózist, a többi hat esetben csak posztmortem autopszia igazolta azt (Sinkó és mtsai. 2008). Megjegyzendő, hogy a klinikai mikrobiológiai diagnosztikai laboratóriumokban nem mindig tesznek különbséget a $C$. parapsilosis (sensu stricto), C. orthopsilosis és $C$. metapsilosis között, így valójában a $C$. parapsilosis sensu latot azonosítják.

\section{III.2.7. A kórokozó Candida fajok és a Candida parapsilosis által okozott betegségek terápiája, és az ellene kialakuló rezisztencia}

A szuperficiális kandidiázisokat hatékonyan gyógyíthatják topikális szerekkel (pl. nisztatin vagy klotrimazol tartalmú készítmények) (Pappas és mtsai. 2004). Invazív infekciók esetén a leggyakrabban alkalmazott gyógyszerek hatóanyagai az ehinokandinok (pl. kaszpofungin), az azolok (pl. flukonazol), az amfotericin-B és a flucitozin (Pappas és mtsai. 2004, Roemer és Krysan 2014). Az egyes Candida fajok eltérő érzékenységgel rendelkezhetnek a különböző hatóanyagokkal szemben, ezért fontos fajszintű meghatározásuk. Például a $C$. krusei valamint számos $C$. glabrata törzs eleve rezisztens flukonazollal szemben (Pappas és mtsai. 2004, Cooper 2011, Roemer és Krysan 2014). Nehezíti továbbá a terápiák hatékonyságát az antimikotikumokkal szemben újonnan kialakuló rezisztencia megjelenése és terjedése (Arendrup 2010).

A C. parapsilosis törzsek is rezisztenciát mutathatnak különböző típusú antifungális hatóanyagokkal (pl. amfotericin B, azolok) szemben (Tóth és mtsai. 2019). Magyarországon péládul amfotericin B-vel, terbinafinnel, flukonazollal, irtakonazollal, vorikonazollal és klotrimazollal szemben rezisztens törzseket is azonosítottak (Zala 2012). A C. parapsilosis 
izolátumok a gombák $\beta$-glükán szintézisét gátló ehinokandin típusú antimikotikumokkal szemben a többi Candida fajhoz képest gyakran kevésbé érzékenyek in vitro körülmények között. Ezen felül in vitro mikroevolúció során további, szerzett rezisztencia is kialakulhat (Papp és mtsai. 2018, Tóth és mtsai. 2019), amely összefügghet a $C$. parapsilosis $\beta$-glükán szintáza Fks1 alegységében megjelenő aminosav polimorfizmusokkal (Perlin 2015, Papp és mtsai. 2018).

\section{III.2.8. Az invazív kandidiázisok epidemiológiája}

A következő rizikófaktorok fennállása növeli az invazív kandidiázisok kialakulásának esélyét:

-immunhiányos állapotok:

- betegség/rendellenesség okozta állapotok: pl. AIDS, egyes hematológiai rendellenességek (pl. neutropénia) vagy genetikai polimorfizmusok.

- orvosilag indukált állapotok: pl. őssejt- vagy szervtranszplantáció esetén alkalmazott immunszuppresszió.

-a szervezet fizikai barrierjeit (bőr, nyálkahártyák) károsító invazív beavatkozások: pl. a hasüregi mütétek, katéterek használata és a parenterális táplálás (Yapar 2014).

A kórokozó Candidák forrása lehet endogén (tápcsatorna, nyálkahártya felszínek), vagy exogén (pl. egészségügyi dolgozók bőre) (Ásmundsdóttir és mtsai. 2008).

A Candida fajok évente 400000-70000 új életveszélyes invazív fertőzést okoznak, melyek mortalitása 46-75\% (Brown és mtsai. 2012, Bongomin és mtsi 2017). Ezekben a kórképekben a gomba gyakran tenyészthető ki vérből, ezért az epidemiológiai tanulmányokban az invazív kandidiázis gyakoriságára a kandidémiás esetek előfordulásából következtetnek. A nozokomiális véráram fertőzések negyedik leggyakoribb okozói Candida gombák, mivel az esetek 10-15\%-áért felelősek (Richardson és Lass-Flörl 2008, Brown és mtsai. 2012). A kandidémia gyakorisága világszinten 2-11/100000 fö (Arendrup 2010), melyet Brown és mtsai. (2012) átlagosan 5,9/100000 főre becsültek. Ez a gyakoriság térségenként eltérő. Míg az USAban 2012-es adatok alapján 8/100000 fö, addig Európában általában kisebb (Yapar 2014). A különböző felmérések szerint ez az érték Angliában és Walesben együttesen 1,52/100000 fö (Oeser és mtsai. 2013), Finnországban 2,86/100000 fő (Poikonen és mtsai. 2010), Svédországban 4,2/100000 fö (Ericsson és mtsai. 2013), Dániában 8,6/100000 fő (Arendrup és mtsai. 2011) volt. Sinkó és mtsai. (2015) becslése alapján Magyarországon évente 1110 kandidémiás eset fordul elő, amely 11/100000 fő gyakoriságnak felel meg. 
A C. albicans felelős leggyakrabban az invazív kandidiázisokért. Rendszeres kommenzalista az ember gasztrointesztinális rendszerében, és élesztő, pszeudohifa, illetve hifa formában is képes növekedni (Turner és Butler 2014, Köhler és mtsai. 2017). Pfaller és mtsai. (2010) szerint további 30 ún. non-albicans Candida faj képes betegéget okozni emberben. Ilyenek pl. a C. dubliniensis, C. glabrata, C. parapsilosis, $C$. orthopsilosis, $C$. metapsilosis, $C$. tropicalis, C. krusei, C. famata, C. lusitaniae, C. guilliermondii, C. kefyr, C. norvegensis, C. lipolytitica és a $C$. inconspicua. A kandidiázisok több mint 90\%-át azonban a következő 5 faj okozza: C. albicans, C. parapsilosis, C. glabrata, C. tropicalis és $C$. krusei (Turner és Butler 2014). Ezeket hazánkban is kimutatták vérmintákból (Dóczi és mtsai. 2002, Majoros és mtsai. 2002). A C. aurist 2009-ben írták le, azonban azóta öt kontinens számos országában izolálták különböző kandidiázisokból, több esetben annak invazív formájából (Jeffery-Smith és mtsai. 2017).

A non-albicans fajokhoz képest a $C$. albicans globálisan csökkenő arányban felel az invazív kandidiázisokért, míg az előbbiek incidenciája növekszik (Arendrup 2010, Yapar 2014, Richardson és Lass-Flörl 2008). Például egy japán nemzeti felmérésben 2003-ban a kandidémiák 58,2\%-át okozta a C. albicans, míg 2014-ben csupán 30\%-át (Kakeya és mtsai. 2018). A non-albicans fajok térnyerésében feltehetően szerepet játszott a flukonazol profilaxis bevezetése a klinikumban, amely a $C$. albicansszal szemben hatásosabb lehet, mint a nonalbicans fajok egy részével (Richardson és Lass-Flörl 2008). Az utóbbiak földrajzi helyzettől függő gyakorisággal vezetnek invazív fertőzésekhez (Függelék 1. ábra).

A C. parapsilosis okozta kandidémiás fertőzések gyógyszeres kezelés mellett a többi gyakori humánpatogén Candida faj által okozottakhoz képest alacsonyabb, 23-28,5\%-os mortalitással járnak (Trofa és mtsai. 2008, Quindós 2014). Ezen fertőzések incidenciája is emelkedő trendet mutat. A C. parapsilosis 1997 és 2000 között világszerte az invazív kandidiázisok 4,8 \%-át, míg 2009-re már 17,1 \%-át okozta (Pfaller és mtsai. 2010, Pfaller és mtsai. 2011). Földrajzi régióktól és páciens csoportoktól függően a kandidémia második vagy harmadik leggyakoribb okozója (Tóth és mtsai. 2019). Latin-Amerikában, Ázsia egyes részein, Ausztráliában és Dél-Európában például a második helyen van (Függelék 1. és 2. ábra) (Quindós 2014, Tóth és mtsai. 2019). Kolumbiában és Venezuelában egy 2008-tól 2010-ig tartó felmérés szerint incidenciája a $C$. albicansét is felülmúlta, így ezekben az országokban ez a gomba okozott leggyakrabban kandidémiát (Nucci és mtsai. 2013). Szerbiában 5 felnőtt intenzív osztályról származó kandidémiás eseteket elemeztek, és a $C$. parapsilosis a $C$. albicansszal egyenlő arányban (46-46\%) okozott ilyen kórképeket (Arsić Arsenijević és mtsai. 2017). 
Pammi és mtsai. (2013) metaanalízise kimutatta, hogy az újszülötteket érintő kandidiázisok 1/3-át a $C$. parapsilosis okozza, ezzel a non-albicans fajok között első helyen szerepel. A nozokomiális C. parapsilosis fertőzések kialakulásának kedvez, hogy a kórházi személyzet kezéről nagy gyakorisággal izolálhatók ezen faj törzsei, melyek átvihetők az ellátottakra (Trofa és mtsai. 2008).

Magyarországon is vizsgálták a kandidémiát okozó fajok relatív gyakoriságát. Dóczi és mtsai. (2002) a Szegedi Tudományegyetem (SZTE) klinikáiról származó vérmintákból tenyésztettek ki Candida fajokat 1996 és 2000 között. Az izolátumok 73,5\%-a C. albicans, 7,3\%-a C. parapsilosis, 5,9\%-a C. krusei, 4,4\%-a C. tropicalis, 3\%-a C. glabrata, a többi egyéb faj volt. Kissé eltérő eloszlást észleltek Majoros és mtsai. (2002) a Debreceni Egyetem klinikáitól 2000-ben érkezett vérminták feldolgozása során: C. albicans (58,33\%), C. tropicalis (16,66\%), C. parapsilosis (8,88\%), C. krusei (8,88\%), egyéb (8,35\%). Hazánkban egyes években a különböző régiók Közegészségügyi Járványügyi Állomásai éves jelentéseit az Országos Közegészségügyi Intézet központilag értékelte, így részletes országos szintü adatsorok álltak elő. Az 1990-es évektől pedig főleg az Állami Népegészségügyi és Tisztiorvosi Szolgálat hálózata gyüjtött országos szinten adatokat (2. ábra).

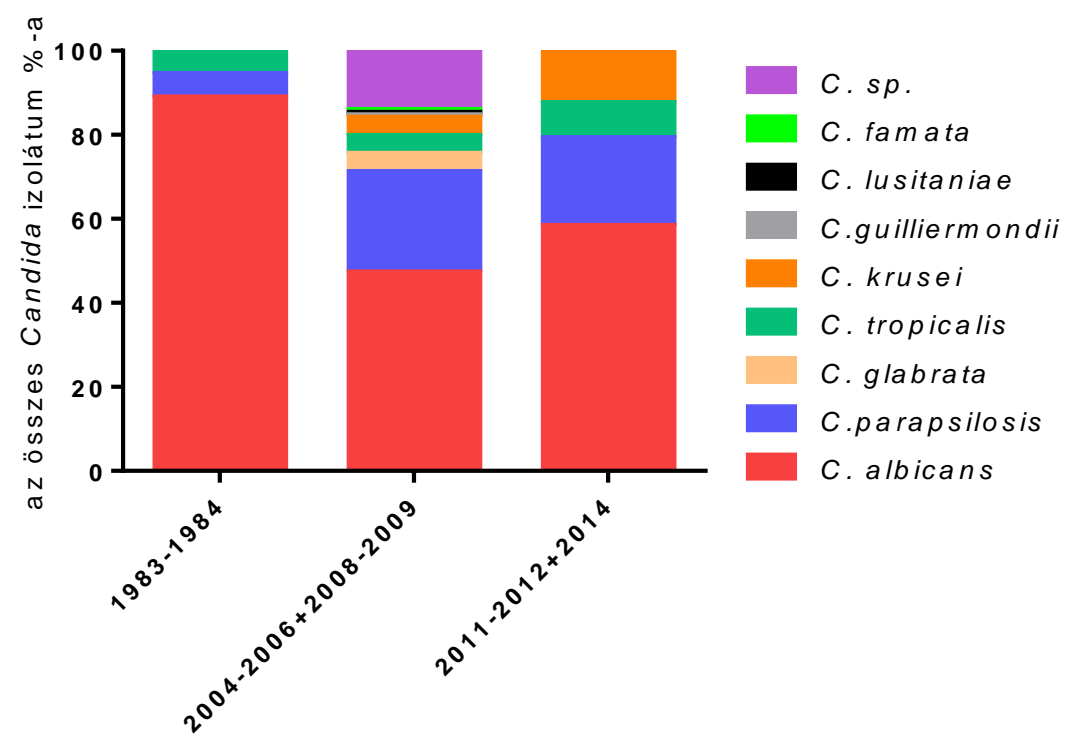

2. ábra. Vérből izolált Candida fajok relatív gyakorisága különböző időszakokban Magyarországon. Az ábra az 1980-as évek két évében regisztrált vérkeringésből izolált, illetve a 2000-2010 időszak néhány évében és a 2010 utáni periódus 3 évében vérmintából származó Candida törzsek fajösszetételét mutatja (KÖJÁL1983, 1984, ÁNTSZ 2004, 2005, 2006, 2008, 2009, 2011, 2012, 2014). 
A C. parapsilosis Magyarországon több évtizede ismert, az Országos Közegészségügyi Intézet például 1958-ban azonosította először klinikai mintából (Bakács 1960). Azóta hazánkban különböző klinikai forrásokból izolálták, ilyenek például a vérminta, szívbillentyü, felső légúti minta, köpet, fül, seb, vizelet, bőr, emésztőszervi és genitális minták (Majoros és mtsai. 2002, ÁNTSZ 2011, ÁNTSZ 2012). A Nemzeti Népegészségügyi Központ és elődei (Országos Epidemiológiai Központ, Országos Közegészségügyi Intézet) az 1996-2009-es időszakban beküldött Candida pozitív vérminták 11,53\%-ából tenyésztettek ki $C$. parapsilosist (Zala 1997, 1998, 1999, 2000, 2001, 2002, 2003, 2004, 2005, 2006, 2007, 2008, 2009, 2010). Az itt összefoglalt hazai adatok illeszkednek a non-albicans fajok, így a C. parapsilosis növekvő incidenciájának nemzetközi trendjéhez.

\section{III.3. A gombaellenes immunválasz}

Szervezetünk folyamatosan ki van téve a környezetben megtalálható vagy a testünkön/testünkben kommenzalistaként élő gombáknak. Ezek opportunista patogénként potenciális veszélyforrást jelenthetnek. Az egészséges immunrendszer általában képes megakadályozni az általuk okozott kóros folyamatokat, melyek ezért főleg az immunitás sérülése esetén jelentkeznek súlyos formában (Romani 2011, Dambuza és mtsai. 2018). Mára az antifungális immunválasz számos elemét azonosították (Salazar és Brown 2018). A kutatások nagy része azonban a legjobban ismert kórokozó gombákra (pl. C. albicans, A. fumigatus, C. neoformans) fókuszál, így számos egyéb fajjal kapcsolatban még kevés vagy nincs konkrét ismeret. A gombaellenes immunválasz részletes megismerése nem csak elméleti szempontból érdekes, hanem gyakorlati vonatkozásai lehetnek hatékonyabb gombaellenes terápiák kidolgozásában (Salazar és Brown 2018).

A gombák elleni védekezéseben mind a veleszületett, mind az adaptív immunrendszer elemei részt vesznek, továbbá olyan sejttípusok is, melyek a kettő közötti átmeneti tulajdonságokat mutatnak. A behatoló kórokozót először a veleszületett immunrendszer ismeri fel, ami az adaptív immunválasz aktivációjához vezet.

\section{III.3.1. Az antifungális veleszületett immunitás általános sémája}

Bőrünk és nyálkahártyáink fizikai barrierként szolgálnak a patogén mikrobákkal szemben, ugyanakkor immunológiai funkciókat (pl. antimikrobiális molekulák vagy citokinek termelése) is ellátnak (Dambuza és mtsai. 2018, Drummond és mtsai. 2014). Sérülésükkor elsőként a természetes immunválasz elemei lépnek fel a behatoló kórokozóval szemben. Az ide tartozó sejtek mintázatfelismerő receptoraik (pattern recognition receptor, PRR) segítségével 
olyan molekuláris mintázatokat (patogén-asszociált molekuláris mintázat, pathogen associated molecular pattern, PAMP) ismernek fel, melyek a kórokozók egyes csoportjaira jellemzők, azonban a gazdaszervezetben fiziológiás esetben nem találhatók meg (Drummond és mtsai. 2014, Dambuza és mtsai. 2017). Más esetben az immunsejtek opszonizált kórokozókat kötnek meg receptoraikkal (Dambuza és mtsai. 2018). A receptor-ligandum kötődés után jelátvitel indul, mely transzkripciós faktorok (pl. NF-kB, AP-1) aktiválásán keresztül vagy anélkül effektor mechanizmusokat mozgósít. Ezek vezetnek közvetve vagy közvetlenül a kórokozó elpusztításához. Ilyenek például a fagocitózis és azt követően a fagolizoszóma-fúzió, a reaktív oxigén (reactive oxygen species, ROS) és nitrogén formák, citokinek, gyulladásos mediátorok vagy antimikrobiális peptidek (AMP) termelése. A citokinek ritkán rendelkeznek direkt antimikrobiális hatással (El-Khoury és mtsai. 2017), föként az immunsejtek közti kommunikációban vesznek részt. Így például a kemokinek a fehérvérsejtek toborzását idézik elő, a pro- és anti-inflammatorikus citokinek a gyulladásos folyamatokat szabályozzák, mások pedig az adaptív immunválasz formálásban játszanak szerepet (Romani 2011, Drummond és mtsai. 2014, Verma és mtsai. 2014).

\section{III.3.2. Az antifungális veleszületett immunitás sejtes elemei}

A neutrofil granulociták általában intenzíven fagocitálják a kórokozó gombákat és ez a sejttípus pusztítja el leghatékonyabban a Candida sejteket (Cheng és mtsai. 2012, Netea és mtsai. 2015). Az utóbbit többek közt oxidatív (pl. ROS és mieloperoxidáz termelés) és egyéb (pl. katepszinek és elasztázok termelése) mechanizmusok segítségével valósítják meg. A neutrofilek továbbá neutrofil extracelluláris csapdák képzésével is reagálhatnak különböző gombák jelenlétére. Ezen DNS, hiszton és AMP tartalmú hálózatos struktúrák a fagocitózishoz túl nagyméretủ struktúrák (pl. hifák) ártalmatlanításában segíthetnek. A neutropéniás állapot az egyik legkomolyabb gombás fertőzésre hajlamosító tényező (Dockrell és mtsai. 2007, Drummond és mtsai. 2014, Netea és mtsai. 2015, Dambuza és mtsai. 2017, Salazar és Brown 2018).

A monociták több típusa Candida sejteket elimináló aktivitással rendelkezik, valamint a monocitopénia vagy a monociták szöveti infiltrációra való képességét károsító mutációk rizikófaktort jelenthetnek invazív gombás betegségekre. Humánpatogén gombák kapcsán mutatták ki monocitákban a „trained” immunitás jelenségét azzal, hogy a $\beta$-glükánnal in vitro stimulált monociták in vivo védő hatást fejtettek ki letális szisztémás kandidiázissal szemben adaptív immunitásukban sérült egerekben (Drummond és mtsai. 2014, Netea és mtsai. 2015, Dambuza és mtsai. 2018, Salazar és Brown 2018). 
A makrofágok is képesek bekebelezni és intracellulárisan elpusztítani a gombasejteket, azonban ölési hatékonyságuk elmarad a neutrofil granulocitákétól. Ezen sejttípus hatékonyan szekretál különböző kemokineket és citokineket, melyek kulcsfontosságúak az egyéb immunsejtek a fertőzés helyére történő toborzásához és a kórokozó gombák elleni gyulladásos válasz kialakításához. A makrofágok antigéneket prezentálnak és olyan citokineket termelnek, melyek a naiv segítő T-sejtek (T-helper, Th) polarizációját alakítják, így fontos szerepet játszanak a gombák ellen kiváltott adaptív immunfolyamatokban is. Ennek megfelelően a makrofág depletált egerek fokozott érzékenységet mutatnak gombás fertőzéssel szemben. Továbbá a monocita eredetű makrofágok szövetekbe történő infiltrációjában szerepet játszó CX3CR1 kemokin receptor csökkent müködésével járó genetikai polimorfizmussal rendelkező páciensek fokozottan veszélyeztetettek szisztémás kandidiázisra nézve. Ismert azonban, hogy az alternatív módon, anti-inflammatorikus citokinek által aktivált M2 fenotípusú makrofágok csökkenthetik a gazdaszervezet gombás fertőzéssel szembeni ellenállóképességét (Heinsbroek és Gordon 2007, Verma és mtsai. 2014, Drummond és mtsai. 2014, Netea és mtsai. 2015, Dambuza és mtsai. 2017, Salazar és Brown 2018).

Bár a dendritikus sejtek is képesek lehetnek a gombasejtek elpusztítására, a gombaellenes immunválaszban betöltött fő szerepüket a veleszületett és adaptív ágak összekötésében jelölik meg. Citokintermelésükkel és antigénbemutatásukkal szabályozzák egyéb sejtek funkcióit. Legnagyobb mértékben ezek a sejtek formálják a naiv Th sejtek polarizációjának irányát (Romani 2007, Verma és mtsai. 2014, Drummond és mtsai. 2014, Netea és mtsai. 2015, Dambuza és mtsai. 2018, Salazar és Brown 2018).

A természetes ölősejtek (natural killer, NK) perforinok segítségével direkt antifungális hatással rendelkezhetnek, továbbá gyulladásos citokineket és kemokineket termelhetnek. Granulocita-makrofág kolónia stimuláló faktor (granulocyte-macrophage colony-stimulating factor, GM-CSF) termelésükkel segíthetik a neutrofilek gombaellenes aktivitását. Több vizsgálatban az NK sejtekre nézve depletált egerek fokozottan érzékenyek voltak gombás fertőzések iránt (Drummond és mtsai. 2014, Netea és mtsai. 2015, Dambuza és mtsai. 2017, Salazar és Brown 2018).

Kevésbé jellemzett néhány egyéb mieloid és limfoid útvonalon képződő immunsejttípus antifungális veleszületett immunitásban betöltött szerepe. Ilyenek a bazofil és eozinofil granulociták, a hízósejtek, a természetes ölő T-sejtek, a veleszületett limfoid sejtek és a $\gamma \delta \mathrm{T}$ sejtek (Wiseman és Mody 2007, Cohen és mtsai. 2011, Drummond és mtsai. 2014, Netea és mtsai. 2015, Salazar és Brown 2018). Ezen kívül további sejttípusok (pl. trombociták, epiteliális 
sejtek) is expresszálhatnak PRR-eket és elláthatnak gombaellenes veleszületett immunológiai funkciókat (pl. AMP-k és citokineket termelése) (Netea és mtsai. 2015, Salazar és Brown 2018).

\section{III.3.3. PRR-ek az antifungális immunitásban}

Jelenleg minimum 36 olyan receptort ismerünk, melyek gomba eredetü PAMP-okat felismerő PRR-ként viselkedhetnek (Függelék 1. táblázat). Közülük a legismertebbek a Ctípusú lektin receptorok (ㄷ-type lectin receptors, CLR-ek) a Toll-szerü receptorok (Toll-like receptors, TLR-ek) és a NOD-szerü receptorok (NOD-like receptors, NLR-ek) (Romani 2011, Drummond és mtsai. 2014).

A legtöbb ilyen PRR a gombasejtfal valamely szénhidrát polimer komponensét köti meg (glükánok, mannánok stb.), azonban a ligandum lehet RNS, metilálatlan DNS, fehérje vagy egyéb kémiai összetételü (Bourgeois és mtsai. 2011, Lionakis és mtsai. 2017, Salazar és Brown 2018, Wang és mtsai. 2019). Az NLR-ek közé tartozó NLRP3 feltételezhetően saját sejt eredetü veszély szignálokat (pl. ROS-ok felhalmozódása) érzékeli, melyek többek között gombás fertőzés során jelennek meg (Skeldon és Saleh 2011, Drummond és mtsai. 2014, Vanaja és mtsai. 2015, Lionakis és mtsai. 2017).

A PRR-ek hatásmechanizmusa többféle. Az extracelluláris PRR-ek opszonizálhatják a gombaelemeket, fokozhatják a komplementrendszer aktivációját és lehetnek közvetlenül antifungális vagy a gombaeredetű extracelluláris vezikulákkal szemben lítikus hatásúak (Richardson és mtsai. 1991, Garlanda és mtsai. 2002, Moalli és mtsai. 2010, Almeida és mtsai. 2017). A legtöbb receptor azonban szignáltranszdukción keresztül transzkripciós faktorok működését szabályozva vált ki válaszreakciót. Az NLR-ek egy része pedig az inflammaszóma fehérjekomplexek érzékelő részeiként működnek. Az inflammaszómák aktivációja az ASC fehérjén keresztül a pro-kaszpáz-1 érett kaszpáz-1-gyé hasadását eredményezi. A kaszpáz-1 a pro-interleukin-1 $\beta$ (pro-IL-1 $\beta$ ) és a pro-IL-18 proteolízisét katalizálja érett formákká. A kaszpáz-1 emellett egyéb funkciókat (pl. programozott sejthalál iniciálása) is elláthat (Netea és mtsai. 2015, Ketelut-Carneiro és mtsai. 2015, Salazar és Brown 2018).

Mivel a kórokozó gombák számos PAMP-pal rendelkeznek, felismerésükben egyszerre több PRR is részt vesz, így az előidézett folyamatok összessége, és a különböző jelátviteli útvonalak egymással való kölcsönhatásai határozzák meg a pontos válaszreakciót (Brown 2011, Salazar és Brown 2018).

Számos PRR gombaellenes immunitásban való részvételét igazolták receptor knock-out egerek segítségével (Netea és mtsai. 2002, Carvalho és mtsai. 2011, Drummond és mtsai. 2014, Netea és mtsai. 2015, Lionakis és mtsai. 2017, Salazar és Brown 2018, Goyal és mtsai. 2018). 
A humán PRR-ek genetikai polimorfizmusainak vizsgálata pedig több esetben összefüggést állapított meg egyes mutációk és a gombás fertőzésekkel szembeni érzékenység között (Függelék 1. táblázat).

\section{III.3.4. Az antifungális adaptív immunitás}

Bár a humánpatogén gombák elleni védekezésben adaptív immunválasz szerepe is bizonyított, a B-sejtek esetén ez nem egyértelmü. A gombás fertőzések hatására antitestek jelenhetnek meg a vérben (Barton 2018) és egyes gomba antigének ellen termeltetett antitestek védelmet biztosíthatnak gombás infekciók ellen (Mukherjee és mtsai. 1993, Nosanchuk és mtsai. 2003, Verma és mtsai. 2014). Ennek ellenére az agammaglobulinémiás vagy hipogammaglobulinémiás állapotok nem tartoznak a gombás fertőzések rizikófaktorai közé (Netea és mtsai. 2015, Lionakis és mtsai. 2017).

A $\mathrm{CD}^{+}$citotoxikus T-sejtek hozzájárulása az antifungális immunitáshoz kevéssé ismert, hatásmechanizmusai között az interferon- $\chi \underline{\chi}$ (IFN- $\gamma$ ) és az IL-17 termelést, illetve a fertőzött sejtekre kifejtett citotoxikus hatást említik (Verma és mtsai. 2014, Dambuza és mtsai. 2018).

A Th sejtek különösen fontosak a gombák elleni adaptív immunválaszban. A naiv Th sejtek egyes sejttípusok antigénprezentációja és citokintermelése hatására különböző fenotípusok irányába polarizálódnak, melyek közül a gombákkal kapcsolatban a Th1, Th2, Th17 és a regulátor T-sejtek (regulatory $\underline{\mathrm{T}}$ cell, $\mathrm{T}_{\mathrm{reg}}$ ) részletesen jellemzettek (Verma és mtsai. 2014, Dambuza és mtsai. 2018).

A Th1 sejtek gombaellenes hatásukat föként az IFN- $\gamma$, kisebb mértékben a tumor nekrózis faktor- $\underline{\alpha}$ (TNF- $\alpha$ ) és a GM-CSF citokinek termelésén keresztül valósítják meg. Az IFN- $\gamma$ és TNF- $\alpha$ többek között a makrofágok klasszikus aktivációját kiváltva hatásosak, továbbá az IFN- $\gamma$ az antigénprezentációt fokozva és antitestek izotípus-váltását elősegítve fokozzák a gombák eliminációját. A GM-CSF többek között a neutrofil granulociták aktivációjával, a makrofágok ROS termelésének fokozásával müködhet közre. A Th1 sejtek dominálta válasz tehát hatékony védelmet eredményezhet a kórokozó gombákkal szemben (Romani 2011, Brown 2011, Verma és mtsai. 2014, Netea és mtsai. 2015, Lionakis és mtsai. 2017, Dambuza és mtsai. 2017, Dambuza és mtsai. 2018).

A Th2 sejtes válasz dominanciája gombás fertőzések során általában kedvezőtlen. Ennek egyik oka lehet, hogy ezen sejtek a makrofágok alternatív aktivációját, az M2 fenotípusú sejtek kialakulását idézik elő (Romani 2011, Brown 2011, Verma és mtsai. 2014, Lionakis és mtsai. 2017, Dambuza és mtsai. 2017, Dambuza és mtsai. 2018). 
A Th17 populáció IL-17, IL-17F és IL-22 expresszióval jellemezhetők, melyek közül az IL-17 és IL-22 jelentősek az antifungállis immunitásban. Az IL-17 a neutrofilek mobilizálását és aktivációját idézi elő. Az IL-17 és IL-22 továbbá fokozzák az epitélsejtek AMP termelését. Állatkísérletben a Th17 válasz hozzájárult a Th1 típusú immnválaszok kialakulásához is. Míg egerekben a Th17 sejtek mind a szisztémás infekciók, mind a nyálkahártyák gombás fertőzései elleni védekezés fontos elemei, addig emberben inkább az utóbbi esetben bizonyították szerepüket (Brown 2011, Romani 2011, Verma és mtsai. 2014, Netea és mtsai. 2015, Dambuza és mtsai. 2017, Lionakis és mtsai. 2017, Dambuza és mtsai. 2018).

A gyulladásos folyamatok kedvezően hathatnak a patogén gombák eliminációjára, azonban szabályozás nélkül a gazdaszervezet épségét is veszélyeztethetik, így patológiássá válhatnak. Gombás fertőzések során a $T_{\text {reg }}$ sejtek egyik funkciója, hogy immunszuppresszív mechanizmusaikkal (pl. IL-10, TGF- $\beta$ termelés) elhárítsák a kóros mértékü immunválasz kialakulását (Romani 2011, Verma és mtsai. 2014, Dambuza és mtsai. 2017, Dambuza és mtsai. 2018).

\section{III.3.5. A Syk és CARD9 jellemzése és szerepük a gombák veleszületett immunrendszer általi érzékelésében}

Egyre több vizsgálat támasztja alá, hogy Syk és CARD9 fehérjék által közvetített jelátvitel jelentős szerephez juthat a humánpatogén gombákkal szemben mutatott immunológiai védekezésben.

A Syk fő izoformája emberben egy 629 aminosav hosszú, 70 kDa molekuláris tömegü

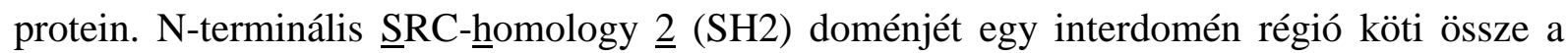
következő SH2 doménnel, melyet szintén egy összekötő szakasz követ a C-terminális tirozin kináz doménig (3. ábra). Létezik egy 23 aminosavval rövidebb izoforma is, mely kevéssé jellemzett. A Syk expressziója a hematopoetikus sejtekben kifejezett, de egyéb szövetek sejtjeire is jellemző. Lokalizációja lehet citoplazmatikus vagy nukleáris. Funkciója sokrétü: a B-sejt receptorok szignalizációjának és ezen sejtek érésének kulcseleme és többek között fagociták adhéziós képességében, NK sejtek antitestfüggő citotoxikus reakciójában, baktériumok immunológiai felismerésében, a trombociták aktivációjában, az oszteoklasztok differenciálódásában, valamint az angiogenezisben is szerepet játszik (Wang és mtsai. 2003, Mócsai és mtsai. 2010, Ma és mtsai. 2016).

A CARD9 egy 62,2 kDa tömegü 536 aminosav hosszúságú (https://www.uniprot.org/uniprot/Q9H257), citoplazmás lokalizációjú fehérje (Hara és Saito 
2009). Jellemző rá egy N-terminális CARD domén, melyet egy rövid szakasz köt össze a nagyobb kiterjedésü „coiled-coil” doménnel (3. ábra). Legnagyobb mértékben mieloid sejtek, különösen dendritikus sejtek és makrofágok expresszálják. A veleszületett immunválaszban legjobban ismert működése egyes mikrobiális PAMP-okat kötő PRR-ek szignáltranszdukciójában azonosítható (Colonna 2007, Ruland 2008, Hara és Saito 2009). Egyéb folyamatokban történő részvételére utalhat, hogy deregulációja összefüggésbe hozható a tumorgenezissel (Zhou és mtsai. 2006, Hara és Saito 2009), és egyes polimorfizmusai kapcsolatba hozhatók különböző gyulladásos betegségek (pl. Chron betegség, ulceratív kolitisz) kialakulásával (Zhernakova és mtsai. 2008).

a

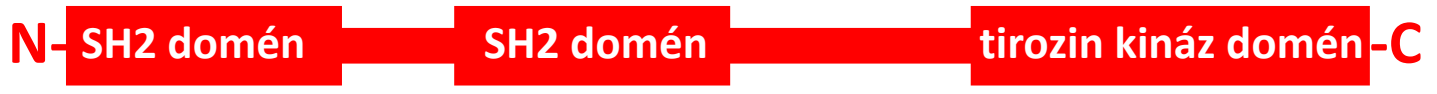

$\mathrm{b}$

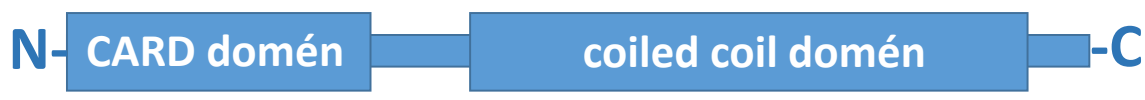

3. ábra. A (a) Syk és a (b) CARD9 fehérjék vázlatos szerkezete. Mócsai és mtsai. (2010), illetve Ruland (2008) alapján.

A Syk és a CARD9 részben közös, részben külön pályákon részt vehetnek az antifungális immunválaszban az által, hogy a kórokozó gombák PAMP-jait felismerő PRR-ek közül a Dectin-1, Dectin-2, Dectin-3, Mincle és komplement receptor 3 (complement receptor 3, CR3) jelátviteli folyamatait közvetítik (Ruland 2008, Mócsai és mtsai. 2010, Salazar és Brown 2018). Ez a szignalizációs út az alábbiak szerint vázolható (4. ábra). A receptorligandum kötődéskor a Dectin-1 ímmunoreceptor tirozin-alapú aktivációs motívum-szerü (ITAM-szerü) motívuma Src kinázok által tirozin oldalláncon foszforilálódik és az SHP-2 foszfatáz által képessé válik a Syk kötésére, mely szintén foszforilálódik. A Dectin-2, Dectin-3 és Mincle ezzel szemben a hozzájuk kapcsolódó FCR $\gamma$ ITAM-ján keresztül aktiválja a Syket. A CR3 ligációja pedig valószínűleg Kindlin-3-függő módon eredményez foszforilált Syket (Drummond és mtsai. 2011, Xue és mtsai. 2013, Gazendam és mtsai. 2014, Deng és mtsai. 


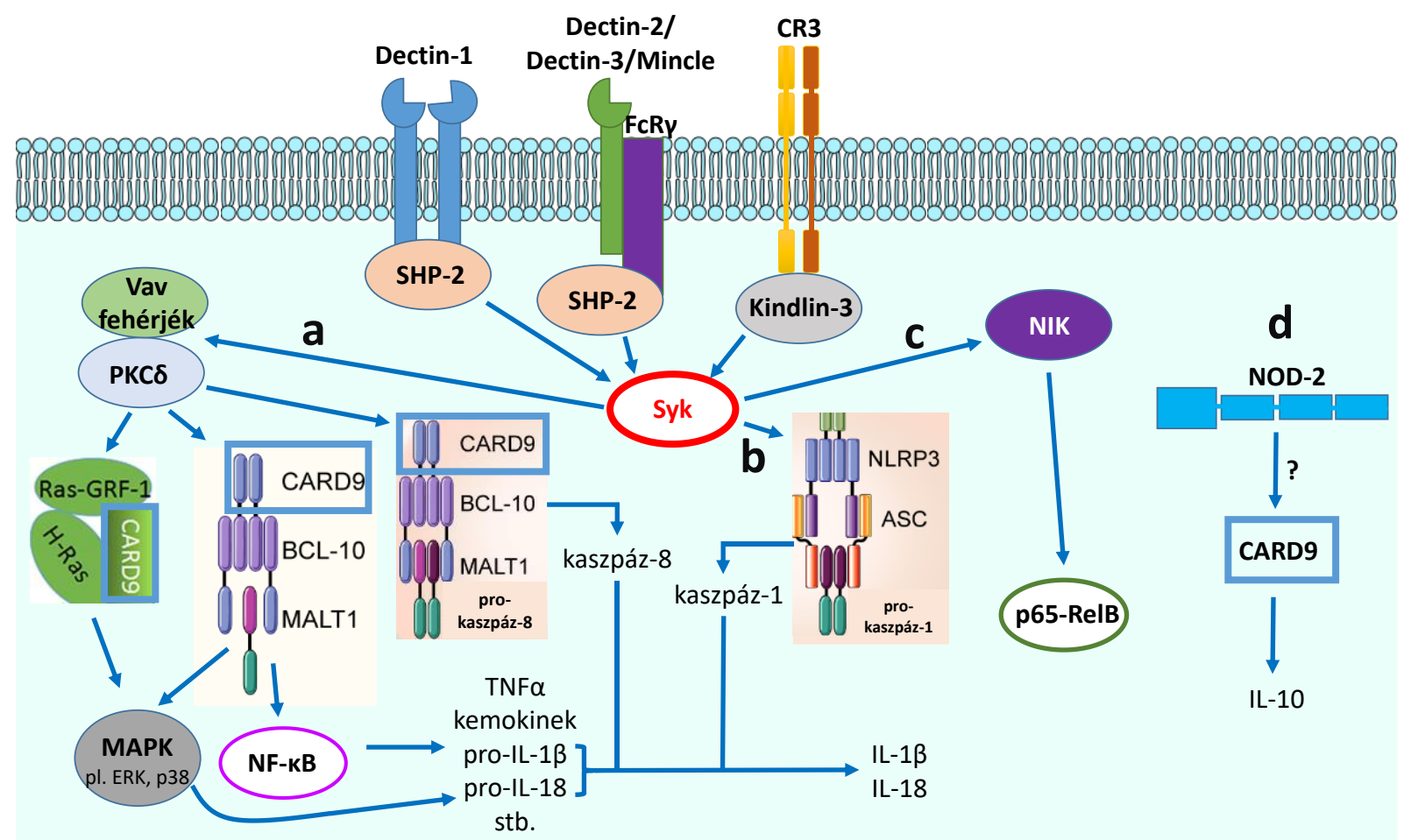

4. ábra. A veleszületett immunválasz Syk és CARD9 közvetítette jelátvitele a kórokozó gombák érzékelése során. Magyarázat a törzsszövegben. Lionakis és Netea (2013), Wagener és mtsai. (2014), Verma és mtsai. (2014), Gazendam és mtsai. (2016), Roth és mtsai. (2016), Dambuza és mtsai. (2017), Tang és mtsai. (2018) és Salazar és Brown (2018) alapján szerkesztve.

2015, Gazendam 2016, Salazar és Brown 2018). A jelátvitel ettől kezdve több útvonalon haladhat:

-CARD9-függő utak (4.a ábra): a szignáltranszdukció több lépésben (Vav fehérjék és

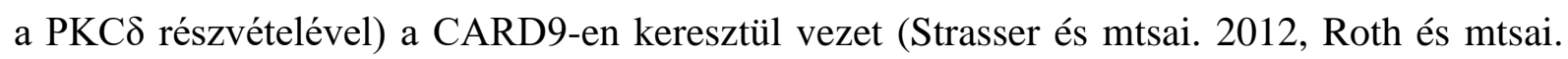
2016). A CARD9 a BCL10-zel és MALT-1-gyel együtt komplexet alkotva transzkripciós faktorok (pl.: NF-кB, NFAT, AP1, IRF-1 és IRF), illetve MAP kinázok (pl. JUNK, p38) aktiválódását okozza. Ezek többek között különböző citokinek/prekurzorok (pl. TNF $\alpha$, pro-IL$1 \beta$ ) termelődését eredményezik (Colonna 2007, Drummond és mtsai. 2014, Verma és mtsai. 2014, Dambuza és Brown 2015, Dambuza és mtsai. 2017, Drummond és mtsai. 2018). A CARD9 egy másik fehérjekomplex (CARD9-H-Ras-Ras-GRF1) részeként, az ERK MAP kináz útvonalat aktiválva is végezhet jeltovábbítást (Jia és mtsai. 2014, Dambuza és Brown 2015). Emellett például $C$. albicans fertőzés során a CARD9-BCL10-MALT-1 komplex az ASC adaptor fehérjével és a kaszpáz-8-cal együtt egy nem kanonikus inflammaszómát képes alkotni, mely IL-1 $\beta$ termelődést vált ki (Gringhuis és mtsai. 2012). 
-NLRP3 inflammaszóma-aktiváció (4.b ábra): a Syk a gombaellenes immunválaszban fontos NLRP3 inflammaszómát is szabályozza. Ennek egyik mechanizmusa a gombák által Syk- függő módon kiváltott ROS termelés, mely ezen inflammaszóma aktivációját okozhatja (Poeck és Ruland 2010, Dambuza és Brown 2015, Dambuza és mtsai. 2017). A Syk továbbá képes fizikailag kötődni az NLRP3-hoz és az ASC-hez, illetve foszforilálni az utóbbit, ez által elősegíteni az inflammaszómák összeszerelődését és müködését (Lin és mtsai. 2015). A $C$. albicans által kiváltott NLRP3 inflammaszóma aktivációt Syk-függőnek találták (Gross és mtsai. 2009).

-az NF-кB indukáló kináz (NIK) aktiváció (4.c ábra): dendritikus sejtekben a Syk képes a NIK-en keresztül nem-kanonikus NF-אB aktivációt (p52-RelB dimerek sejtmagi transzlokációja, majd inaktív p65-RelB dimerek kialakulása) kiváltani, azonban ennek jelentősége gombás fertőzésekben kevéssé ismert (Gringhuis és mtsai. 2009, Kerrigan és Brown 2010, Verma és mtsai. 2014).

A PRR-ekhez kapcsolódó jelátviteli útvonalak összefonódása megfigyelhető a Syk/CARD9 jelpályák esetén is (Drummond és mtsai. 2011). Kimutatták például, hogy a Dectin-1 és egyes TLR-ek Syk- és Myd88-függő (a TLR-ek egyik fő downstream szignalizációs komponense) módon egymás hatását szinergisztikusan fokozva alakítottak ki citokinválaszokat, mivel a két szignáltranszdukció az NF-kB-ben összeérve annak fokozott sejtmagi transzlokációját okozta (Gantner és mtsai. 2003, Dennehy és mtsai. 2008). Bővíti ismereteinket, hogy humán monocitákban leírták a Syk TLR4-gyel és Myd88-cal történő fizikai asszociációját, valamint az LPS-sel stimulált TLR4 által közvetített folyamatok részben Sykdependens regulációját (Chaudhary és mtsai. 2007). Továbbá egyelöre nem tisztázott, hogy a CARD9 részt vesz-e a TLR-ek saját szignalizációjában (Colonna 2007, Ruland 2008). Gross és mtsai. (2006) vizsgálataiban a különböző TLR ligandumokkal kezelt CARD9-/- dendritikus sejtek citokintermelése nem tért el a vad típusúakétól, valamint Hsu és msti (2006) munkájában a hasonlóan stimulált mutáns makrofágok citokintermelése is részben megegyezett azzal. Hara és mtsai. (2007) kísérleteiben részben az előzőekkel megegyező ligandumokat alkalmazva a makrofágokkal kapcsolatban hasonló eredményre jutottak, azonban a CARD9 ${ }^{-/-}$dendritikus sejtek TNFa és IL-6 produkciója alacsonyabb volt a vad típusú sejtekhez képest. Mivel mindhárom kutatásban azonos egértörzset és hasonló génkiütési stratégiákat alkalmaztak, az eltérések oka bizonytalan. Az antifungális immunválaszt érintő szakirodalomban azonban a Syket és CARD9-et jellemzően nem hozzák összefüggésbe a TLR-ek saját, nem jelátviteli összefonódásból („,cross-talk”) adódó szignalizációjával. 
A CARD9 részt vesz a Listeria monocytogenes baktérium NOD2 intracelluláris receptor általi érzékelésének jelközvetítésében is (Hsu és msti 2006). Wagener és mtsai. (2014) kimutatták, hogy a NOD2 a kitin érzékelésével a $C$. albicans felismerésében is részt vesz. Mivel a kitin sem a CARD9 ${ }^{-/-}$sem a NOD2 ${ }^{-/}$makrofágokban nem indukált IL-10 termelést, modelljükben feltételezték a CARD9 szerepét a NOD2 szignalizációjában (4.d ábra).

Egy vizsgálatban a $C$. albicans Dectin-2 közvetítette felismerése Syk-független, de

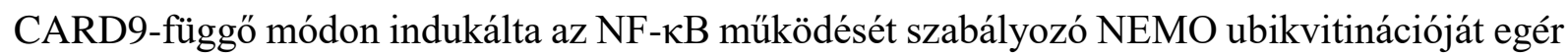
makrofágokban. Továbbá a Syk gátlása úgy downregulálta az NF-אB aktiválásához vezető utat, hogy közben nem befolyásolta érdemben a CARD9 és a BCL10 asszociációját. Ennek hatására a szerzők olyan modellt vetítettek fel, amelyben a Dectin-2 jelátvitelében a CARD9 és a Syk egymástól függetlenül szabályozzák az NF-kB aktivációját (Bi és mtsai. 2010).

A Syk/CARD9 szignalizáció a már említett receptorok jeltovábbításában nem feltétlenül kizárólagos. Például a Dectin-1 Syk/CARD9-től független, Raf-1 által mediált szignáltranszdukciója is fontos eleme a gombaellenes immunológiai mechanizmusoknak (Gringhuis és mtsai. 2009).

\section{III.3.6. A Syk és CARD9 szerepe az anti-Candida immunitásban}

Mind a Syk, mind a CARD9 számos sejtbiológiai folyamat révén járul hozzá a Candida fajok elleni immunitáshoz (Drummond és mtsai. 2011, Drummond és mtsai. 2018). Egér makrofágszerü sejtekben a $C$. glabrata kiváltotta a Syk foszforilációját, azonban ez nem járt együtt a NF-кB (p65) magi transzlokációjával (Kasper és mtsai. 2014). Ezzel szemben egyes

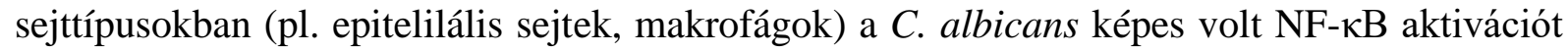
előidézni (Roeder és mtsai. 2004, Moyes és mtsai. 2010, Jia és mtsai. 2014), melynek mértéke CARD9 $^{-/-}$makrofágokban a vad típusúakénál alacsonyabb volt (Bi és mtsai. 2010). Gringhuis és mtsai. (2009) pedig $\beta$-glükánnal stimulált dendritikus sejtekben találta Syk-függőnek az NFкB aktivációját. Ezekhez az eredményekhez igazodik, hogy elégtelen Syk-aktiváció esetén a

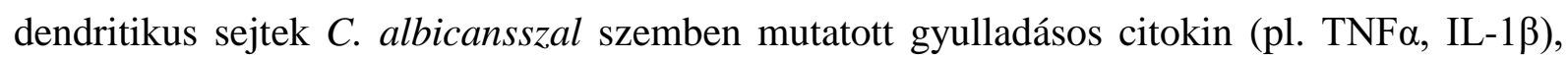
valamint kemokin [(pl. keratinocyte chemoattractant $(\mathrm{KC})$, macrophage inflammatory protein2 (MIP-2)] termelése alacsony volt (Deng és mtsai. 2015), valamint, hogy C. albicansszal fertőzött egerekben a dendritikus sejtek IL-23p19 termelése Syk-függőnek bizonyult (Whitney és mtsai. 2014). Több kutatás igazolta továbbá, hogy egyes $C$. albicansszal vagy $C$. tropicalisszal fertőzött CARD9-- immunsejtek vagy szövetek gyulladásos citokin (pl. TNF $\alpha$, IL-6) és kemokin (pl. KC, MIP-2) produkciója is sérült (Gross és mtsai. 2006, Drummond és mtsai. 2015, Whibley és mtsai. 2015). A CARD9 által mediált TNF $\alpha$-indukció egér modellben 
a C. tropicalis elleni rezisztenciában kulcsfontosságúnak bizonyult (Whibley és mtsai. 2015). A citokintermelés nemcsak a gyulladást és az immunsejtek toborzását, hanem az adaptív immunválasz minőségét is modulálhatja Candida fertőzés során. A $C$. albicans Dectin-1 és Dectin-2 általi felismerése a Syk/CARD9 útvonalon Th17 választ idézett elő (LeibundGutLandmann és mtsai. 2007, Robinson és mtsai. 2009). Ezt megerősíti, hogy a Syk CLR-ek általi aktivációjában szereplő SHP-2 tirozin foszfatázra nézve hiányos, C. albicansszal fertőzött egerekben a Th17 válasz szintén defektív volt (Deng és mtsai. 2015).

A Syk a fagociták bekebelező képességében is közremüködhet, amit a CARD9-töl függetlennek tekintenek (Ruland 2008, Roth és mtsai. 2016). Az élesztők sejtfalát modellező, magas $\beta$-glükán tartalmú zimozán fagocitózisa dendritikus sejtekben Syk-függő volt (Rogers és mtsai. 2005). A piceatannol Syk inhibitorral kezelt fibroblasztok, valamint az SHP-2 foszfatáz hiányos makrofágok is csökkent mértékben internalizálták a zimozánt (Herre és mtsai. 2004, Deng és mtsai. 2015). Más Syk inhibitorral kezelt egér makrofágok $C$. glabratát fagocitáló képessége viszont csak alacsony mértékben és rövid inkubációs idő mellett múlta alul a kontroll sejtekét (Dagher és mtsai. 2018). Mások Syktől függetlennek találták a makrofágok zimozánt bekebelező képességét (Herre és mtsai. 2004, Underhill és mtsai. 2005). A zimozán felvétele CARD9-függetlennek bizonyult makrofágokban és dendritikus sejtekben egyaránt (Gross és mtsai. 2006, Goodridge és mtsai. 2009).

A Syk részt vehet a fagoszómák érési folyamatában is. Gátlása ugyanis hátráltatta az „élesztő partikulum” tartalmú fagoszómák és a lizoszómák fúzióját (Majeed és mtsai. 2001). Egér makrofág jellegű sejtvonalban pedig a Syk és Src kinázok inhibitoros blokkolása gátolta a C. albicans tartalmú fagoszómák savasodását (Mansour és msti 2013). A C. glabrata esetén ez a Syk-függés még nem nyert igazolást, azonban a lehetősége már felmerült (Kasper és mtsai. 2014). Egy tanulmányban továbbá egy CARD9-deficiens páciensből származó neutrofil granulocitákban a $C$. albicanst tartalmazó fagoszómák rendellenes, duzzadt ultrastruktúrát mutattak (Drewniak és mtsai. 2013).

Vizsgálták a Syk és CARD9 hatását az immunsejtek Candidákkal szembeni ölési képességére, illetve az internalizált gombasejtek intracelluláris osztódási kapacitására. A humán neutrofilek mind a CR3 által érzékelt opszonizálatlan, mind az Fc $\gamma \mathrm{R}$ által kötött IgGopszonizált C. albicans sejteket Syk-függő módon pusztították el (Gazendam és mtsai. 2014). A Syk egyik gátlószerével kezelt egér makrofágok pedig csökkent mértékben voltak képesek kontrollálni a C. glabrata intracelluláris osztódását (Dagher és mtsai. 2018). Li és mtsai. (2016) kísérleteiben a CARD9-- egér neutrofil granulociták $C$. albicanst ölő képessége ép volt. Whibley és mtsai. (2015) ugyanezt tapasztalták egér neutrofil granulociták és monociták $C$. 
tropicalist elimináló aktivitásával kapcsolatban. Olyan humán neutrofilekben és monocitákban azonban, melyekben a CARD9 müködése mutáció miatt sérült, a $C$. albicans élesztő formájának elpusztítása akadályozott volt, míg a hifális forma ellenes képesség érintetlen maradt (Drewniak és mtsai. 2013, Drummond és mtsai. 2015).

A fentiekkel összhangban a Syk/CARD9 utakon keresztül szignalizáló különböző receptorokra (Salazar és Brown 2018), a Sykre, az SHP-2-re vagy a CARD9-re hiányos kísérleti állatok nagyfokú érzékenységet mutattak $C$. albicans vagy $C$. tropicalis fertőzésekkel szemben (Gross és mtsai. 2006, Jia és mtsai. 2014, Whitney és mtsai. 2014, Deng és mtsai. 2015, Whibley és mtsai. 2015). A Dectin-1 vagy Dectin-2 egyes polimorfizmusai emberben is gombás fertőzések rizikófaktorai lehetnek (Függelék 1. táblázat). A humán CARD9 egyes mutációi szintén súlyos gombás fertőzések (pl. a központi idegrendszer kandidiázisa) kialakulására tesznek hajlamossá (Glocker és mtsai. 2009, Drummond és mtsai. 2015, Lanternier és mtsai. 2015).

\section{III.3.7. A C. parapsilosis elleni immunválasz}

A C. albicans által indukált immunválaszhoz képest a $C$. parapsilosisszal kapcsolatban keveset tudunk (Tóth és mtsai. 2019). Többféle, veleszületett immunitásban szereplő sejttípusról (pl. epiteliális sejtek, neutrofilek, makrofágok, dendritikus sejtek) kimutatták a $C$. parapsilosis felismerésében történő részvételt. A megfigyelt válaszok között szerepelt a különböző citokinek és $\beta$-defenzinek termelése, az inflammaszóma aktiváció, az ún. fungipod állábak fejlesztése, a komplement aktiváció, a fagocitózis, a fagoszómák savasodása és az intracelluláris ölés. Idáig a TLR2, TLR4, TLR6, TLR7, Galektin-3, Dectin-1, NLRP3 és NOD2 receptorokat hozták összefüggésbe a $C$. parapsilosis immunológiai felismerésével. Ehhez a jelátvitel szintjén többek között a Myd88, Syk, ASC, IRAK, kaszpáz-1, kaszpáz-8, NF-кB és MAP kinázok hozzájárulásáról vannak adatok (van Asbeck és mtsai. 2008, Bahri és mtsai. 2010, Neumann és Jacobson 2010, Nagy és mtsai. 2011, Horváth és mtsai. 2012, Linden és mtsai. 2013, Németh és mtsai. 2013, Tóth és mtsai. 2013, Tóth és mtsai. 2015, Patin és mtsai. 2016, Duan és mtsai. 2017, Tóth és mtsai. 2017).

Az adaptív immunitás terén egér modellben bizonyították, hogy rekombináns antitest felhasználásával mérsékelhető a $C$. parapsilosis elszaporodása a szervezetben (Matthews és mtsai. 2003). Perifériás vérből származó mononukleáris sejtekkel végzett in vitro kísérletekben pedig a $C$. parapsilosis eltérő Th-sejtes választ eredményezett a $C$. albicans által indukálttól, például kisebb mértékben váltotta ki a Th17 sejtek megjelenését (Tóth és mtsai. 2013). Továbbá a funkcionális T- és B-sejt képzésre képtelen ún. súlyos kombinált immunhiányos (severe 
combined immunodeficient, SCID) egerek fokozott érzékenységgel voltak jellemezhetőek kísérletes $C$. parapsilosis fertőzés során (nem publikált adat).

A Syken keresztül szignalizáló PRR-ek közül eddig egyedül a Dectin-1-ről igazolták, hogy in vitro részt vesz a $C$. parapsilosis felimerésében (Tóth és mtsai. 2013, Duan és mtsai. 2017, Thompson és mtsai. 2019). Ezen vizsgálatok többsége (Tóth és mtsai. 2013, Duan és mtsai. 2017) azonban hővel elölt Candida sejtekkel történt, és ez az állapot nem tükrözi a gombasejtfal fiziológiás szerkezetét, mivel ilyenkor a Dectin-1 liganduma, a $\beta$-glükán a sejtfal felszínén fokozottan hozzáférhetővé válhat (Gow és mtsai. 2007). Laborunk eredményei alapján a Dectin- $1^{-/-}$egerek nem voltak érzékenyebbek a $C$. parapsilosisra, mint a vad típusúak (Csonka 2018). Thompson és mtsai. (2019) vizsgálatában C . parapsilosis fertőzés során a Dectin- $1^{-/}$állatok gomba általi kolonizáltsága csak rövid fertőzési idő esetén volt magasabb a vad típúsúakénál, míg hosszabb időtartam alkalmazásakor ez a különbség megszünt. Azonban a Syk inhibitorral történő gátlása lecsökkentette az élő $C$. parapsilosisszal kezelt humán THP1 makrofágszerü sejtek IL-1 $\beta$ termelését (Tóth és mtsai. 2017). A CARD9-ről a C. parapsilosis tekintetében csupán az ismert, hogy nem vesz részt az ezen gomba által indukált IL-27 termelésben (Patin és mtsai. 2016).

Több non-albicans fajról (C. tropicalis, C. glabrata) kimutatták, a C. albicans esetében leírtakhoz képest eltérő immunreakciókat válthatnak ki (Seider és mtsai. 2011, Whibley és mtsai. 2015). A C. parapsilosisra az eltérő Th sejtes válasz mellett például a C. albicanséhoz képest alacsonyabb inflammaszóma aktivációs képesség jellemző (Tóth és mtsai. 2017). Továbbá egerekkel végzett kísérletekben a C. parapsilosis - a C. albicansszal ellentétben - az IL-27 termelését váltotta ki mieloid sejtekben, és a $C$. parapsilosisszal fertőzött IL-27 receptor hiányos egerekben a gyulladásos és adaptív válaszok (pl. IFN $\gamma$ és IL-17 termelés) erősödésével együtt a virulencia lecsökkent. Feltételezhető tehát, hogy az IL-27 indukciója a C. parapsilosis egyik olyan stratégiája, amely által a protektív immunválaszokat downregulálja (Patin és mtsai. 2016).

\section{III.3.8. Az antifungális immunterápia}

Az invazív mikózisok máig magas mortalitása szükségessé teszi további antimikotikumok és hatékony terápiák kidolgozását. Mivel a súlyos gombás fertőzések gyakran immundeficiens állapotok következtében alakulnak ki, racionális az elgondolás, hogy az immunrendszer antifungális mechanizmusainak fokozásával növelhető a gyógyszeres kezelések hatékonysága. Ez az irányvonal a kiegészítő antifungális immunterápia. Ennek 
előfeltétele a gombák által kiváltott immunválasz ismerete (Casadevall és Pirofski 2001, Armstrong-James és Harrison 2012).

Több megközelítés közül egyeseket már sikeresen alkalmaztak a klinikumban (Ravikumar és mtsai. 2015). Már a gombák felismerésében részt vevő PRR-ek stimulálása is kedvezően befolyásolhatja a gyógyulás folyamatát. Egy klinikai vizsgálat például az Imiquimod nevü TLR7 agonistát hatékonynak találta kromoblasztomikózisos bőrelváltozások kezelésében (De Sousa és mtsai. 2014). A citokinekkel történő kezelésre példák a Th1 sejtes immunválaszt mimikáló IFN $\gamma$ és GM-CSF terápiák, melyek szintén eredményesek voltak gombás fertőzés esetén (Segal és mtsai. 2006, Kullberg 2007). Feltehetően szintén a Th1 válasz serkentésével magyarázható a lepketaplóból (Trametes versicolor) kinyert PSK nevü proteinglükán frakció állatkísérletekben megfigyelt protektív hatása szisztémás kandidiázissal szemben (Ohmura és mtsai. 2001, Ohmura és mtsai. 2003). A különböző immunsejtek (pl. neutrofilek, gomba antigén specifikus Th sejtek) betegekbe történő átültetése is többször hatékony megközelítésnek bizonyult. A gombaellenes antitestek klinikai tesztelései is elkezdődtek. Bár jelenleg nincsen emberi alkalmazásra engedélyezett gombaellenes vakcina, ezek fejlesztései folyamatban vannak, és alkalmazhatóságukat a preklinikai vizsgálatok igazolhatónak mutatták (Ravikumar és mtsai. 2015, Carvalho és mtsai. 2017). Állatkísérletekben Th1- és Th17-függő mikrobaellenes immunitást sikerült kiváltani olyan vakcinációs stratégiákkal, melyekben a Syk/CARD9 úton szignalizáló CLR-ek ligandumait használták fel adjuvánsként. Ezek emberben való alkalmazhatóságát is felvetették (Lang és mtsai. 2011). A Syk aktivitásának terápiás szabályozása nem példa nélküli. Az első a Syk aktivitását közvetlenül célzó hatóanyagú (Fostamatinib) gyógyszert egyéb típusú betegségek kezelésére az utóbbi években engedélyezték az USA-ban (Markham 2018).

A tumorellenes immunterápiáknak napjainkban jelentős és sikeres alkalmazásai léteznek (Galluzzi és mtsai. 2018). Bár ezekhez képest a gombaellenes immunterápia kezdeti stádiumban van, a jövőben ez jelentheti az egyik irányt a súlyos mikózisokkal folytatott küzdelemben. Emiatt sürgető a gombák által kiváltott protektív immunválasz megismerése. Mivel ez a válasz akár közelrokon humánpatogén gombafajokkal szemben is eltérő lehet, szükség van ezen fajspecifikus folyamatok megismerése. Így például kifejezetten a $C$. parapsilosis okozta invazív fertőzések egyik potenciális immunterápiájaként jelölték meg az IL-27 jelátvitel blokkolását, mivel ez vélhetően olyan gyulladásos folyamatok gátlásának feloldásához vezet, amelyek hatékony védelmet jelentenek ezen faj ellen (Patin és mtsai. 2016). 


\section{Célkitüzések}

Az egyre növekvő jelentőségű opportunista humánpatogén $C$. parapsilosis az invazív kandidiázis egyik rendszeres okozója, azonban az általa kiváltott immunfolyamatokról kevés ismeretünk van. A Syk és CARD9 fehérjék részt vesznek egyes PRR-ek jelátvitelének közvetítésében, és alapvető szerepet játszanak a $C$. albicans elleni védekezésben. Előzetes munkánkban a Syk blokkolása csökentette a $C$. parapsilosisszal fertözött THP-1 sejtek IL-1 $\beta$ termelését, azonban ezen kívül a Syk és a CARD9 C. parapsilosis fertőzések során betöltött szerepe tisztázatlan.

Ezek fényében célul tüztük ki annak vizsgálatát, hogy a Syk/CARD9 jelátvitel - a $C$. albicans esetével összehasonlításban - részt vesz-e a $C$. parapsilosis immunrendszer általi felismerésében és az általa kiváltott immunológiai folyamatokban. Konkrétabb célunk volt, hogy csontvelői kiméra transzgénikus egérmodellek segítségével:

1. in vitro meghatározzuk, hogy a Syk vagy CARD9 befolyásolja-e a makrofágok $C$. parapsilosis fertőzésre adott sejttani válaszait (pl. transzkripciós faktor aktiváció, citokintermelés), valamint,

2. in vivo teszteljük, hogy a Syk és CARD9 deléciója a hematopoetikus sejtkészletből a C. parapsilosisszal fertőzött egerek fokozott érzékenységéhez vezet-e. 


\section{Anyagok és módszerek}

\section{V.1. Táptalajok, tápoldatok, pufferek és egyéb reagensek}

Kísérleteinkhez az alábbi tápoldatokat, táptalajokat, reagenseket és egyéb oldatokat használtuk fel:

-Dimetil-szulfoxid (DMSO): a Sigma-Aldrich D2650 katalógusszámú terméke.

-Alexa Fluor® 488 szukcinimidil észter: az Invitrogen A20000 katalógusszámú terméke. A por formájú festéket DMSO-ban oldottuk fel, így $1 \mathrm{mg} / \mathrm{ml}$-es törzsoldathoz jutottunk. Ezt $-20{ }^{\circ} \mathrm{C}$ on tároltunk.

-Marha szérum albumin (bovine serum albumin, BSA): a Sigma-Aldrich A7906-50G katalógusszámú terméke.

-Foszfát pufferes sóoldat (phosphate buffered saline, PBS): $137 \mathrm{mM} \mathrm{NaCl}, 2,7 \mathrm{mM} \mathrm{KCl}, 10$ $\mathrm{mM} \mathrm{Na}_{2} \mathrm{HPO}_{4}, 2 \mathrm{mM} \mathrm{KH} 2 \mathrm{PO}_{4}$ vízben feloldva $(\mathrm{pH} 7,4)$.

-Fetális borjú szérum (fetal bovine serum, FBS): a Euroclone terméke (katalógusszám: ECS0180L). Felhasználás előtt a szérumot $56^{\circ} \mathrm{C}$-on 30 percig hővel inaktiváltuk.

-FBS-PBS: PBS kiegészítve 10 V/V\% FBS-el.

-4 \% PFA-PBS: 4 V/V\% paraformaldehid (PFA) PBS-ben oldva.

-Triton X-PBS: 0,3 V/V\% Triton X-100 PBS-ben.

- Hank-féle pufferelt sóoldat (Hanks' balanced salt solution, HBSS) puffer: a Lonza terméke, katalógusszám: BE10-527F.

-YPD (yeast extract-peptone-dextrose) tápoldat/táptalaj: 0,5 m/V\% élesztökivonat, $1 \mathrm{~m} / \mathrm{V} \%$ pepton, $1 \mathrm{~m} / \mathrm{V} \%$ glükóz tartalmú tápoldat 100 I.U./ml penicillinnel és $100 \mu \mathrm{g} / \mathrm{ml}$ sztreptomicinnel (Lonza, katalógusszám: DE17-602E) kiegészítve. Szilárd táptalaj készítésekor $2 \mathrm{~m} / \mathrm{V} \%$ agarral egészítettük ki a tápoldatot.

-DMEM (Dulbecco's modified Eagle's medium) tápoldat: a Lonza, BE12-604F katalógusszámú terméke.

-Kiegészített DMEM tápoldat: DMEM tápoldat kiegészítve 100 I.U./ml penicillinnel és 100 $\mu \mathrm{g} / \mathrm{ml}$ sztreptomicinnel és 10V/V\% (hőinaktivált) FBS-sel.

-BMDM médium: 20 V/V\% L929 kondicionált médium tartalmú kiegészített DMEM tápoldat. -L929 kondicionált médium: L929 egér fibroblasztokkal 10 napon keresztül koinkubált, sterilre szürt, nem kiegészített DMEM tápoldat. Elkészítését lásd az V.4.3. fejezetben.

-TrypLETM Express Enzyme oldat: a Gibco (Life Technologies) 12604-013 katalógusszámú terméke.

- $\underline{\mathrm{Na}_{2}} \underline{\mathrm{CO}}_{3}$ oldat: $1 \mathrm{M}$ vízben oldott $\mathrm{NaCO}_{3}, \mathrm{pH} 10$. 
-pHrodo ${ }^{\mathrm{TM}}$ Red festék: az Invitrogen P36600 katalógusszámú terméke. A por formájú festéket DMSO-ban oldottuk fel, így $1 \mathrm{mM}$-os törzsoldatot készítettünk, melyet -20 ${ }^{\circ} \mathrm{C}$-on tároltunk. -DRAQ5 ${ }^{\mathrm{TM}}$ fluoreszcens sejtmagfesték: a Thermo Fisher Scientific 62251 katalógusszámú terméke.

-antitestek: a felhasznált antitestekről és jelen munkában történt felhasználási céljukról az 1. táblázat tájékoztat.

Egyes kísérletekben további oldatokat is felhasználtunk, melyeket az adott módszertan leírásánál tüntettünk fel.

1. táblázat. A jelen munkához felhasznált antitestek néhány jellemzője.

\begin{tabular}{|c|c|c|c|c|c|}
\hline Specificitás & Fluorofór & Felhasználás & Eredet & Gyártó & Katalógusszám \\
\hline egér CD45.2 & $\begin{array}{c}\text { fluoreszcein- } \\
\text { izotiocianát (FITC) }\end{array}$ & $\begin{array}{l}\text { csontvelői kimérák } \\
\text { ellenőrzése }\end{array}$ & egér & $\begin{array}{c}\text { BD- } \\
\text { Biosciences }\end{array}$ & 561874 \\
\hline egér Ly6G & PerCP-Cy ${ }^{\mathrm{TM}} 5.5$ & $\begin{array}{l}\text { csontvelői kimérák } \\
\text { ellenőrzése }\end{array}$ & patkány & $\begin{array}{c}\text { BD- } \\
\text { Biosciences }\end{array}$ & 560602 \\
\hline egér B220 & fikoeritrin (PE) & $\begin{array}{l}\text { csontvelői kimérák } \\
\text { ellenőrzése }\end{array}$ & patkány & $\begin{array}{c}\text { BD- } \\
\text { Biosciences }\end{array}$ & 553089 \\
\hline $\begin{array}{l}\text { egér/humán } \\
\text { NF-кB p65 }\end{array}$ & Alexa Fluor® 488 & $\begin{array}{c}\text { NF-kB magi } \\
\text { transzlokáció } \\
\text { vizsgálata }\end{array}$ & egér & R\&D Systems & IC5078G \\
\hline $\begin{array}{l}\text { egér/humán } \\
\text { CD11b }\end{array}$ & $\mathrm{PE}$ & $\begin{array}{l}\text { makrofágok } \\
\text { ellenőrzése }\end{array}$ & patkány & Sony & 1106035 \\
\hline vegyes & PE & $\begin{array}{l}\text { izotípus kontroll az } \\
\text { előző antitesthez }\end{array}$ & patkány & Sony & 2603175 \\
\hline egér F4/80 & Alexa Fluor® 488 & $\begin{array}{l}\text { makrofágok } \\
\text { ellenőrzése }\end{array}$ & patkány & Biolegend & 123119 \\
\hline vegyes & Alexa Fluor® 488 & $\begin{array}{c}\text { izotípus kontroll az } \\
\text { elöző antitesthez }\end{array}$ & patkány & Biolegend & 400525 \\
\hline
\end{tabular}

\section{V.2. Candida törzsek}

Munkánkhoz a C. parapsilosis GA1, CLIB214 és CDC317 jelzésü klinikai izolátumait használtuk fel. Ezeket több kutatásban alkalmazták (pl. Wang és mtsai. 2012, Tóth és mtsai. 2015, Tóth és mtsai. 2017), nukleáris genomszekvenciájuk ismert (Logue és mtsai. 2005, Butler és mtsai. 2009, Pryszcz és mtsai. 2013, http://www.candidagenome.org/Strains.shtml\#parapsilosis). Felhasználtuk továbbá a CLIB214 
törzs zöld fluoreszcens fehérjét (green fluorescent protein, GFP) expresszáló transzformánsát (GFP-CLIB214), melyet laborunkban Dr. Németh Tibor hozott létre (2. táblázat).

A C. albicans esetén a kutatásokban széleskörüen alkalmazott SC5314 klinikai izolátummal dolgoztunk, melynek teljes sejtmagi genomszekvenciája szintén ismert (Jones és mtsai. 2004, http://www.candidagenome.org/Strains.shtml) (2. táblázat).

2. táblázat. A jelen munkához felhasznált Candida törzsek néhány jellemzője. SZMC: Szegedi Mikrobiológiai Törzsgyüjtemény (http://szmc.hu/welcome/).

\begin{tabular}{|c|c|c|c|c|c|}
\hline Törzs/Faj & SZMC kód & Genotípus & Származás & Eredet & Hivatkozás \\
\hline $\begin{array}{c}\text { GA1/ } \\
\text { C. parapsilosis }\end{array}$ & SZMC 8110 & vad típus & $\begin{array}{c}\text { Hamburg, } \\
\text { Németország }\end{array}$ & humán vér & $\begin{array}{c}\text { Gácser és mtsai. } \\
2005\end{array}$ \\
\hline $\begin{array}{c}\text { CDC317/ } \\
\text { C. parapsilosis }\end{array}$ & SZMC8114 & vad típus & $\begin{array}{l}\text { Mississippi, } \\
\text { USA }\end{array}$ & $\begin{array}{c}\text { kórházi ápoló keze, } \\
\text { a törzs kórházi } \\
\text { fertőzéseket okozott }\end{array}$ & $\begin{array}{l}\text { Kuhn és mtsai. } \\
2004\end{array}$ \\
\hline $\begin{array}{c}\text { CLIB214/ } \\
\text { C. parapsilosis }\end{array}$ & SZMC 1560 & vad típus & Puerto Rico & humán széklet & $\begin{array}{l}\text { Laffey és Butler } \\
2005\end{array}$ \\
\hline $\begin{array}{l}\text { GFP-CLIB214/ } \\
\text { C. parapsilosis }\end{array}$ & - & $\mid \begin{array}{c}\text { CpNEUT5L/ } \\
\text { CpNEUT5L:: } \\
\text { pEXPR- } \\
\text { PCaTDH3- } \\
\text { GFP::SAT1 }\end{array}$ & $\begin{array}{c}\text { Szeged, } \\
\text { Magyarország }\end{array}$ & $\begin{array}{c}\text { CLIB214 vad típusú } \\
\text { törzs }\end{array}$ & - \\
\hline $\begin{array}{l}\text { SC5314 } \\
\text { C. albicans }\end{array}$ & SZMC 1523 & vad típus & New York, USA & $\begin{array}{c}\text { szisztémás } \\
\text { kandidiázisban } \\
\text { szenvedő páciens }\end{array}$ & $\begin{array}{c}\text { Gillum és mtsai. } \\
1984\end{array}$ \\
\hline
\end{tabular}

A törzseket YPD táptalajon $4{ }^{\circ} \mathrm{C}$-on tartottuk fent, és havonta frissítettük őket. Ilyenkor friss táptalajra oltottuk őket, amit 2 napos $30^{\circ} \mathrm{C}$-on történő inkubáció követett.

\section{V.3. Kísérleti állatok}

A laboratóriumi egereket felhasználásig szabályozott körülmények között tartottuk: 12 óra fény/12 óra sötét ciklus, $21^{\circ} \mathrm{C}$, ad libitum elérhető ivóvíz és normál rágcsálótáp. $\mathrm{Az}$ 
állatkísérleteink engedélyszáma XVI./3646/2016, melyet a CSI/01/3646-6/2016 hivatkozási számú módosítási határozat egészít ki.

Syk hiányos és CARD9 hiányos csontvelői kimérákat (jelölésük: Syk ${ }^{-/-}$kimérák és $\mathrm{CARD}^{-/-}$kimérák) és a kontroll csontvelői kiméra állatokat [jelölésük: $\mathrm{Vt}(\mathrm{Syk})$ kiméra és Vt(CARD9) kiméra] használtunk fel. A Syk ${ }^{-/-}$és CARD9-/- kimérák hematopoetikus eredetü sejtjeiben a megfelelő géntermékek nem expresszálódtak. Az állatokat a Semmelweis Egyetem Élettani Intézetében müködő Gyulladásélettan Kutatócsoport munkatársai [Csepregi Janka, Orosz Anita, Szénási Nikolett: Syk $^{-/-}$és Vt(Syk) kimérák; Dr. Németh Tamás: CARD9-/- és Vt(CARD9) kimérák] állították elő és ellenőrizték. Mivel a Syk kifejeződésének hiánya homozigóta formában perinatális letalitásal jár (Cheng és mtsai. 1995, Turner és mtsai. 1995) a $\mathrm{Syk}^{-/-}-\mathrm{Vt}(\mathrm{Syk})$ kiméra, illetve a CARD9 ${ }^{-/-}-\mathrm{Vt}(\mathrm{CARD} 9)$ kiméra párok létrehozása eltérően zajlott.

A Syk ${ }^{-/-}$és Vt(Syk) kiméra állatok előállítása Jakus és mtsai. (2010) alapján embrionális májsejt transzplantációval a következő módon történt. C57BL/6 hátterü 18 napos $\mathrm{Syk}^{+/+}$vagy

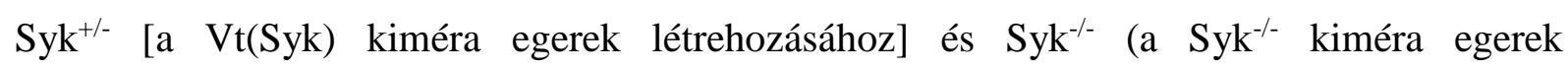
létrehozásához) embriókból májsejteket izoláltak. Ezeket intravénás úton szintén C57BL/6 hátterű recipiens állatokba injektálták, melyeket előzetesen 12,5 percig $11 \mathrm{~Gy}$ dózisú, ${ }^{137} \mathrm{Cs}$ forrású sugárzásnak tettek ki. A besugárzást a Gamma-Service Medical cég (Lipcse) D1 besugárzó készülékével végezték. A csontvelői repopuláció sikerességét 4 hét elteltével ellenőrizték. Ehhez az állatok perifériás vérét mintázták, melyet a B220, Ly6G és CD45.2 sejtfelszíni markerekre festettek meg áramlási citometriás vizsgálathoz. A Syk ${ }^{-/-}$kimérák létrehozását sikeresnek tekintették, amennyiben $500 \mathrm{db}$ neutrofil granulocita $\left(\mathrm{CD} 45.2^{+} \mathrm{Ly}_{6 \mathrm{G}^{+}}\right.$ sejt) leszámolása alatt eltelt időben a B-sejtek (B220+ ${ }^{+}$sejtek) száma nem haladta meg a 8 százalékot. A Syk ${ }^{-/-}$kimérákban ugyanis a B-limfociták képzése defektív (Turner és mtsai. 1995, Cheng és mtsai. 1995).

A CARD9-- és Vt(CARD9) kimérákat Németh és mtsai. (2016) alapján csontvelőátültetéssel állították elő az alábbiak szerint. A CD45 génjének CD45.2 alléljére homozigóta C57BL/6 hátterü CARD9+/+ ${ }^{+a}$ Vt(CARD9) kimérák létrehozásához] és CARD9 ${ }^{-/-}$(a CARD9-kimérák létrehozásához) állatokból csontvelői sejteket izoláltak, majd ezeket intravénás úton a C57BL/6 törzzsel kongenikus B6.SJL-Ptprc ${ }^{\mathrm{a}}$ (BoyJ) recipiens állatokba injektálták, melyek a transzplantációt megelőző sugárkezelés előtt eredetileg CD45.1 allélre nézve voltak homozigóták. Négy hét múlva a csontvelő donor eredetű repopulációjának sikerességét a perifériás vérből származó neutrofil granulociták CD45.2 expressziója alapján ellenőrizték áramlási citometriával. Amennyiben a neutrofil granulociták (Ly6G ${ }^{+}$sejtek) legalább $98 \%$-a 
CD45.2 $2^{+}$volt, a transzplantáció sikeresnek minősült. A csontvelői kimérákat a transzplantáció után 4-10 héttel használtuk fel.

\section{V.4. Sejtkultúrák és sejtvonalak}

Kísérleteinkhez egér csontvelőből differenciáltatott makrofágokat ( derived macrophages, BMDM) és több esetben peritoneális makrofágokat (peritoneal macrophages, PM) használtunk fel. A BMDM kultúrák előállításához az M-CSF termelő L929 egér fibroblaszt sejtvonalat alkalmaztuk.

A sejteket $37{ }^{\circ} \mathrm{C}$-on, $5 \% \mathrm{CO}_{2}$ tartalmú és $100 \%$ relatív páratartalmú atmoszférában tartottuk fenn, valamint a kísérleti kezelések is ezen körülmények között zajlottak.

\section{V.4.1. A BMDM-ek tenyésztése}

A BMDM-eket Deng és mtsai. (2015), valamint Bourgeois és mtsai. (2009) alapján hoztuk létre, néhány módosítással. Az egerekből kiboncoltuk a comb- és a sípcsontokat, majd PBS-be helyeztük azokat. Ezután 10 másodpercig 70 V/V\% etanolban áztattuk, majd ismét PBS-be helyeztük a csontokat. Az epifíziseket levágtuk, majd 26G-s injekciós tủvel PBS segítségével 50 ml-es Falcon csövekbe mostuk a csontvelőket. Ezt 10 perces 1000 RPM fordulatszámú, 1-es fokozatú gyorsulású és lassulású centrifugálás követte Heraeus Multifuge 3 S-R centrifugában. A felülúszókat leöntöttük és a pelleteket BMDM médiumban szuszpendáltuk. A szuszpenziót $100 \mu \mathrm{m}$ pórusátmérőjü szürőn keresztuil átmostuk, majd sejttenyésztő lemezekbe mértük. Az egy állatból származó csontvelőszuszpenziót egy teljes tenyésztő lemezbe (12 vagy 24 tenyésztőhelyü) pipettáztuk tenyésztőhelyenként 1-1 (12 helyes lemez) vagy 0,5-0,5 (24 helyes lemez) ml BMDM médiumban. A Syk ${ }^{-/-}$kimérákból származó teljes csontvelőszuszpenziókat a tenyésztő lemezek mintahelyeinek összesen negyedébe adagoltuk ki. A 12 mintahelyes lemez esetén a tenyészetekre két nap múlva további 1-1 vagy 24 helyes lemez esetén 0,5-0,5 ml BMDM médiumot mértünk a korábbi médium leszívása nélkül. További két és négy nap elteltével a lemezek óvatos rázását követően tápoldatot cseréltünk. A hetedik napon az adherens sejtek nyúlványos fenotípust mutattak, konfluens réteget alkottak (5. ábra) és kísérletre felhasználhatóak voltak. 
a

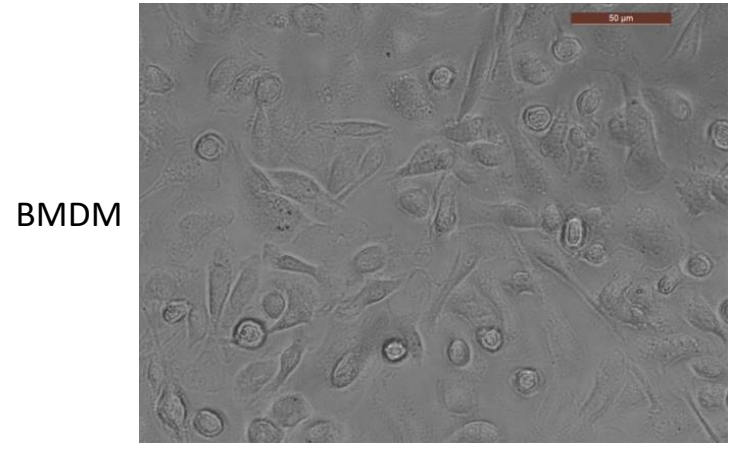

PM

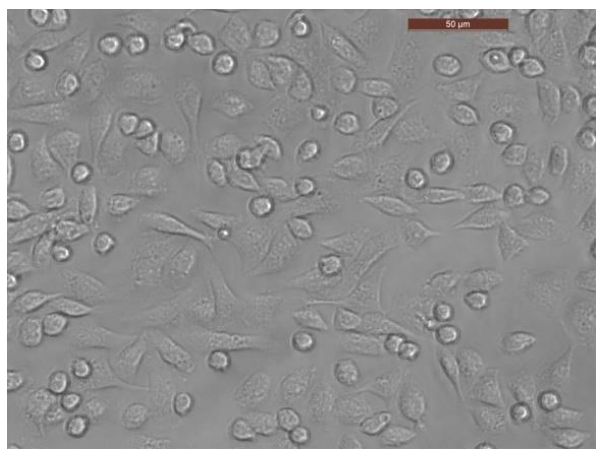

b

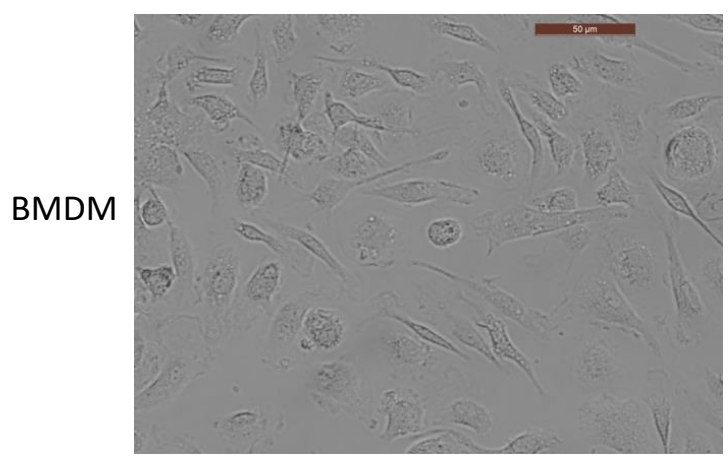

PM

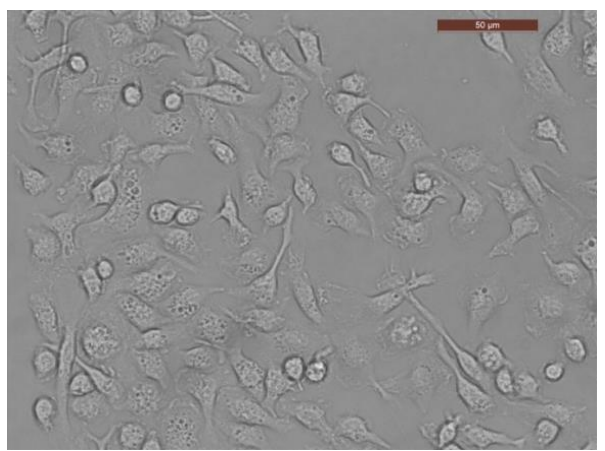

$\mathrm{Syk}^{-/-}$kiméra
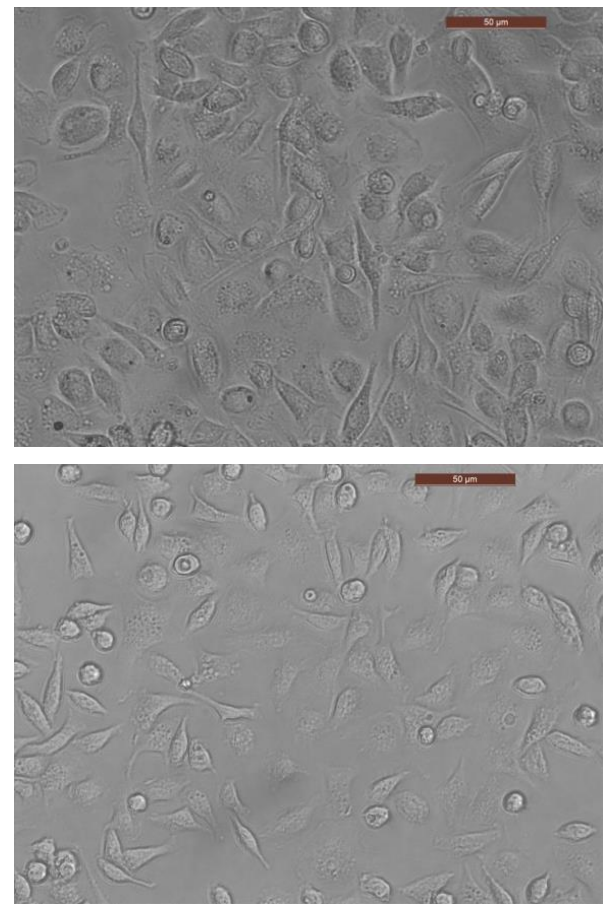

CARD9\%- kiméra
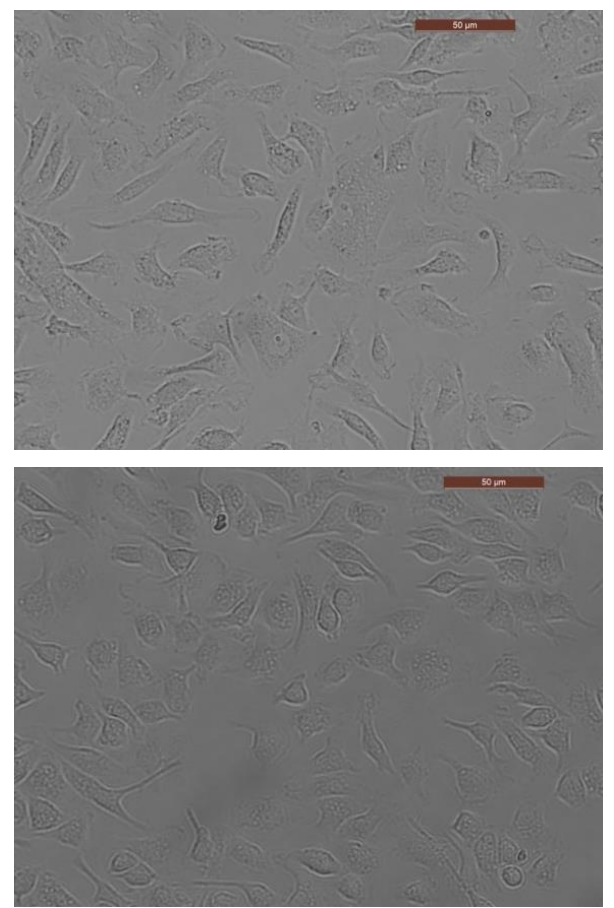

5. ábra. A kísérletre kész sejtkultúrák fénymikroszkópos felvételei. (a) $\mathrm{Vt}(\mathrm{Syk})$ és $\mathrm{Syk}^{-/-}$, valamint (b) Vt(CARD9) és CARD9 ${ }^{-/-}$kiméra állatokból származó sejtek. PM: peritoneális makrofág; BMDM: csontvelőből differenciáltatott makrofág. Skála: $50 \mu \mathrm{M}$. 


\section{V.4.2. A PM-ek tenyésztése}

A PM-ek izolálását szakirodalmi ismeretek (Villamón és mtsai. 2004, Underhill és mtsai. 2005, Bajtai és Sármay 2006, Zhang és mtsai. 2008, Dennehy és mtsai. 2008,) és saját tapasztalataink figyelembevételével végeztük.

Az egerek hasüregébe $5 \mathrm{ml}$ jéghideg PBS-t juttattunk 26 G-s injekciós tüvel, majd a has enyhe masszírozása után újabb 5 ml-t. Ismételt masszírozást követően a peritoneális üregből visszaszívtuk a folyadékot, majd $50 \mathrm{ml}$-es Falcon csőbe mértük. Ezután újra $5 \mathrm{ml}$ puffer injektálása, masszírozás, visszaszívás és a peritoneális lavage ugyanazon Falcon csőbe helyezése következett. Egy állatból így 12-13 ml peritoneális lavage volt kinyerhető. A folyadékot centrifugáltuk (10 perc, 1000 RPM, 1-es fokozatú gyorsulás és lassulás, Heraeus Multifuge $3 \mathrm{~S}-\mathrm{R}$ centrifuga). A felülúszót eltávolítottuk, majd a sejteket $2 \mathrm{ml}$ kiegészített DMEM tápoldatban szuszpendáltuk. A szuszpenzióból 12 helyes tenyésztő lemezek esetén 1 ml-t mértünk 1 tenyésztőhelybe, 24 helyes esetben pedig 0,5 ml-t, míg 96 helyes lemezek esetében 0,25 ml-t. A következő két napon a tenyésztő lemezek rázása után tápoldatot cseréltünk. Az adherens sejtek ilyenkor nyúlványos morfológiát mutattak, általában konfluens réteget alkottak (5. ábra) és kísérletre felhasználhatóak voltak.

\section{V.4.3. Az L929 sejtvonal és az L929 kondicionált médium}

Az L929 kondicionált médiumot Bourgeois és mtsai. (2009) munkája alapján készítettuik. Az L929 fibroblasztok a Szegedi Biológiai Kutatóközpontjában működő Tumorimmunológiai és Farmakológiai Csoporttól származtak.

A krioprezervált L929 sejteket kiolvasztottuk, majd centrifugálás után (800 RPM, 5 perc, Heraeus Pico 17 mikrocentrifuga) 10 ml 10\% FBS-sel kiegészített DMEM tápoldatban vettük fel és 75 ml-es sejttenyésztő flaskában neveltük. Minden második napon tápoldatot cseréltünk a sejteken. A tenyészet konfluenssé válásakor sejtkaparóval leválasztottuk a fibroblasztokat az edény alzatáról, majd centrifugálással ülepítettük (50 ml-es Falcon csőben, 10 perc, 1000 RPM, 1-es fokozatú gyorsulás és lassulás, Heraeus Multifuge 3 S-R centrifuga), és $40 \mathrm{ml}$ 10\% FBS-sel kiegészített DMEM tápoldatban szuszpendáltuk azokat. A szuszpenziót 4 flaskába osztottuk (10 ml/flaska). A tenyészeteken 2 naponta tápoldatot cseréltünk. Amikor a sejtek konfluens réteget alkottak, leszívtuk a tápoldatot és flaskánként $50 \mathrm{ml}$ nem kiegészített DMEM médiumot mértünk kultúrákra. Ezt 10 napos inkubáció követte. A 10. napon a 4 flaskából származó felülúszókat egyesítettük, majd 0,45 $\mu \mathrm{m}$ pórusátmérőjű szűrővel sterilre szürtük a folyadékot. Az elkészült L929 kondicionált médiumot $-20{ }^{\circ} \mathrm{C}$-on tároltuk alkalmazásig. 


\section{5. Kísérleti módszerek}

\section{V.5.1. A makrofágok tenyésztési módszerének ellenőrzése}

A felhasználásra kész PM és BDMD kultúrák előállítási módját a CD11b és F4/80 egér makrofág markerek immunfestésével ellenőriztük (Ghosn és mtsai. 2010, Berta 2014). A 12 mintahelyű sejttenyésztő lemezekben tenyésztett sejteket tenyésztőhelyenként $500 \mu 1$ PBS-sel mostuk kétszer, végül $300 \mu$ l PBS-t mértünk a tenyésztőhelyekbe. Ebbe adagoltuk az antitesteket: $2 \mu 1$ Alexa Fluor® 488-cal konjugált patkányban termelt anti-egér F4/80 antitestet vagy ugyanennyi Alexa Fluor® 488- konjugált patkány eredetű IgG2a, $\kappa$ izotípus kontroll antitestet, továbbá 1,25 $\mu 1$ patkány eredetủ PE-el konjugált anti-egér/humán CD11b antitestet vagy azonos mennyiségü patkány eredetü $\operatorname{IgG} 2 b$, $\kappa$ izotípus kontroll antitestet. A tenyésztő lemezt alumínium fóliával lefedtük, majd fél óra inkubáció következett $4{ }^{\circ} \mathrm{C}$-on. Ezt újabb kétszeri mosás követte PBS-el. Végül mintahelyenként 1-1 ml jéghideg PBS erős pipettázásával szuszpendáltuk a sejteket, melyeket mikrocentrifuga csövekbe vittünk át. A csöveket 5 percen át centrifugáltuk 2000 RPM beállítással, Heraeus Pico 17 mikrocentrifugában. A felülúszók leöntése után $100 \mu 1$ PBS-ben vettük fel a sejteket, és jégre helyeztük azokat. A szinglet sejteket az Amnis FlowSight ${ }^{\circledR}$ Imaging Flow Cytometer müszerrel fehér fény és 488 nm hullámhosszú lézeres megvilágítása mellett vizsgáltuk. Az adatok kiértékelését az IDEAS ${ }^{\circledR} 6.2$ szoftverrel végeztük. Az Alexa Fluor ${ }^{\circledR} 488$ és a PE emissziós spektrumainak átfedését a két fluorofór együttes elemzésére létrehozott kompenzációs mátrix segítségével küszöböltük ki. Ekkor a CD11b expressziójáról informáló PE eredetü fluoreszcencia a harmadik csatornán (Ch03), míg az F4/80 kifejeződésével korreláló Alexa Fluor® 488 eredetü emisszió a második csatornán (Ch02) volt detektálható. A kapuzás során az izotípus kontroll antitestekkel festett azonos genotípusú sejtek által kijelölt tartományt tekintettuik negatívnak.

Mind a csontvelőből differenciáltatott, mind a peritoneális üregből tenyésztett adherens sejtek többsége ( $\geq 80 \%) \mathrm{CD} 11 \mathrm{~b}^{+} \mathrm{F} 4 / 80^{+}$volt (6. ábra), mely alapján tenyésztési módszereinket megfelelőnek tekintettük.

\section{V.5.2. Mikroszkópia}

A sejtkultúrákról készült fénymikroszkópos felvételeket Leica DMI4000 B inverz mikroszkóp segítségével a Leica Application Software 4.2. verziójával vizualizáltuk. A szövettani metszetekről BX51 OLYMPUS típusú mikroszkóppal készítettünk fényképeket. Az egyéb mikroszkópos képeket az Amnis FlowSight@ Imaging Flow Cytometer készülékkel rögzítettük. Ezeket az az IDEAS $\bowtie 6.2$ szoftverrel jelenítettünk meg. 
a

Vt(Syk) kiméra

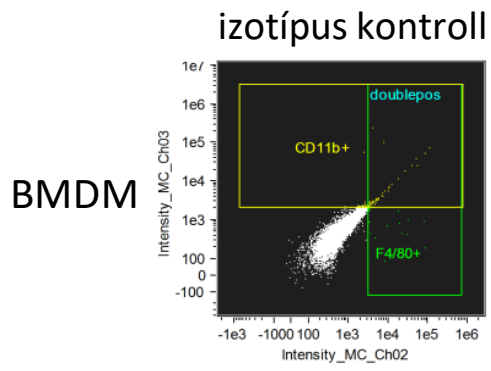

Intensity_MC_Ch02, Intensity_MC_Ch03 \begin{tabular}{|l|c|c|}
\hline Population & Count & $\%$ Gated \\
\hline All & 2000 & 100 \\
\hline
\end{tabular} \begin{tabular}{|l|l|l|}
\hline All & 20000 & 100 \\
\hline doublepos & 55 & 0.27 \\
\hline
\end{tabular}

PM

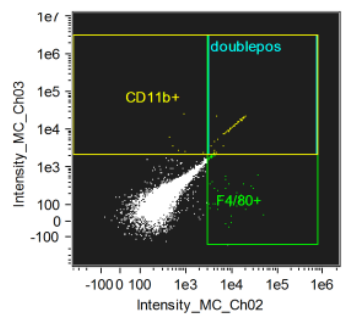

Intensity MC Ch02 Intensity_MC Ch03 \begin{tabular}{|l|l|l|}
\hline Population & Count & $\%$ Gated \\
\hline All & &
\end{tabular} \begin{tabular}{|l|l|l|}
\hline All & 10000 & 100 \\
\hline doublepos & 46 & 0.46 \\
\hline
\end{tabular}
CD11b+F4/80 festett

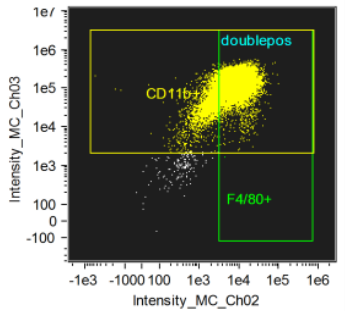

Intensity_MC_Ch02, Intensity_MC_Ch03 \begin{tabular}{|l|l|l|}
\hline Population & Count & $\%$ Gated \\
\hline All & 2000 & 100 \\
\hline
\end{tabular} \begin{tabular}{|l|l|l|}
\hline All & 20000 & 100 \\
\hline doublepos & 17403 & 07 \\
\hline
\end{tabular}

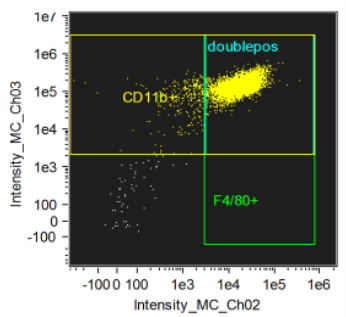

Intensity_MC_Ch02, Intensity_MC_Ch03 \begin{tabular}{|l|l|l|}
\hline Population & Count & $\%$ Gated \\
\hline All & 10000 & 100 \\
\hline
\end{tabular} \begin{tabular}{|l|l|l|l}
\hline All & 10000 & 100 \\
\hline
\end{tabular}

b

$$
\text { Vt(CARD9) kiméra }
$$

izotípus kontroll

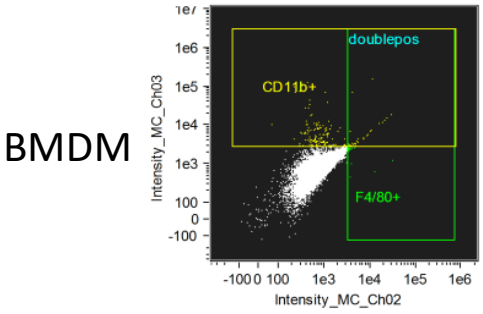

Intensity MC Ch02, Intensity MC ChO3 \begin{tabular}{|l|c|c|}
\hline Population & Count & $\%$ Gated \\
\hline All & 2000 & 100 \\
\hline
\end{tabular} \begin{tabular}{|l|l|l|}
\hline All & 20000 & 100 \\
\hline doubleps & 25 & 0.12 \\
\hline
\end{tabular}

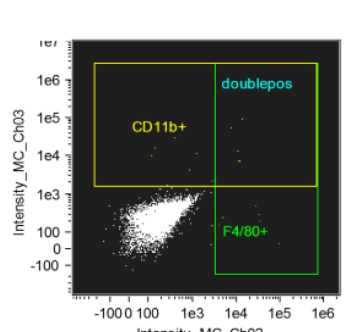

$\begin{array}{lllll}100 & 103 & 104 & 105 & 106\end{array}$

Intensity_MC_Ch02, Intensity_MC_Ch03 \begin{tabular}{|l|l|l|}
\hline Population & Count & $\%$ Gated \\
\hline All & 1000 & \\
\hline
\end{tabular} \begin{tabular}{|l|l|l|}
\hline All & 10000 & 100 \\
\hline
\end{tabular}

\section{$\mathrm{CD} 11 \mathrm{~b}+\mathrm{F} 4 / 80$ festett}

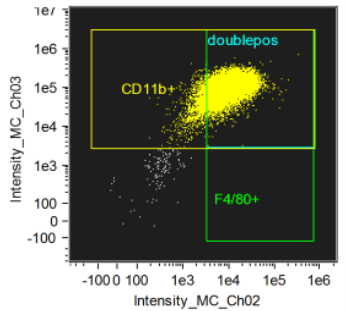

Intensity_MC_Ch02, Intensity_MC_Ch03 \begin{tabular}{|l|l|l|}
\hline Population & Count & $\%$ Gated \\
\hline All & 20000 & 100 \\
\hline
\end{tabular} \begin{tabular}{|l|l|l|}
\hline All & 20000 & 100 \\
\hline doublepos & 18484 & 924 \\
\hline
\end{tabular}

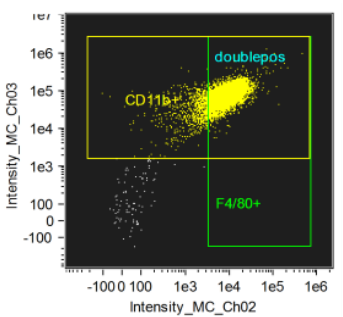

Intensity_MC_Ch02, Intensity_MC_Ch03 \begin{tabular}{|l|c|c|}
\hline Population & Count & $\%$ Gated \\
\hline All & 10000 & 100 \\
\hline
\end{tabular} \begin{tabular}{|l|l|l|}
\hline All & 10000 & 100 \\
\hline
\end{tabular}
Syk ${ }^{-/-}$kiméra

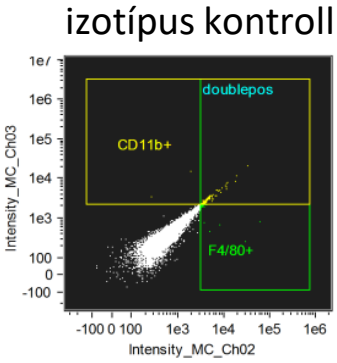

Intensity_MC_Ch02, Intensity_MC_Ch03 \begin{tabular}{|l|l|l|}
\hline Population & Count & $\%$ Gated \\
\hline All & 2000 & 100 \\
\hline
\end{tabular} \begin{tabular}{|l|l|l|}
\hline All & 20000 & 100 \\
\hline doublepos & 109 & 0.55 \\
\hline
\end{tabular}

CD11b+F4/80 festett

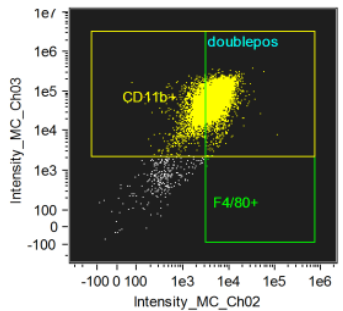

Intensity_MC_Ch02, Intensity_MC_Ch03 \begin{tabular}{|l|c|c|}
\hline Population & Count & \%Gated \\
\hline All & 20000 & 100 \\
\hline
\end{tabular} \begin{tabular}{|l|l|l|}
\hline All & 20000 & 100 \\
\hline doublepos & 16016 & 80.1 \\
\hline
\end{tabular}
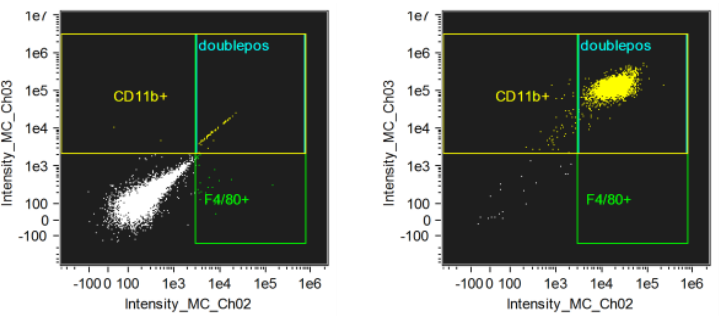

Intensity_MC_Ch02, Intensity_MC_Ch03 \begin{tabular}{|l|c|c|}
\hline Population & Count & \% Gated \\
\hline All & 8984 & 100 \\
\hline
\end{tabular} \begin{tabular}{|l|l|l|}
\hline All & 8984 & 100 \\
\hline doublepos & 63 & 07 \\
\hline
\end{tabular}

Intensity_MC_Ch02, Intensity_MC_Ch03 \begin{tabular}{|l|c|c|}
\hline Population & Count $\%$ Gated \\
\hline Al & soon & \\
\hline
\end{tabular} \begin{tabular}{|l|l|l|}
\hline All & 5000 & 100 \\
\hline
\end{tabular}
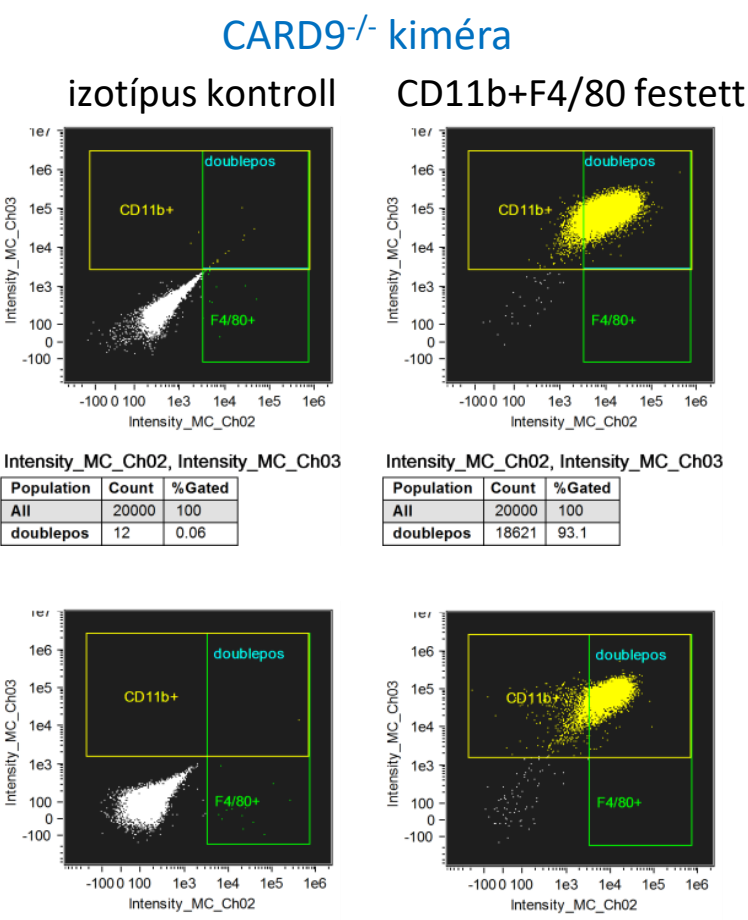

Intensity MC Ch02, Intensity MC Ch03 \begin{tabular}{|l|l|l|}
\hline Population & Count & $\%$ Gated \\
\hline All & 10000 & \\
\hline
\end{tabular} \begin{tabular}{l|l|l|l|}
\hline All & 10000 & 100 \\
\hline
\end{tabular}

Intensity MC Ch02 Intensity MC_Ch03 \begin{tabular}{|l|l|l|}
\hline Population & Count & $\%$ Gated \\
\hline
\end{tabular} \begin{tabular}{|l|l|l|}
\hline All & 10000 & 100 \\
\hline
\end{tabular}

6. ábra. A makrofágtenyészetek ellenőrzése. A sejteket PE-vel jelölt anti-CD11b és Alexa Fluor® 488hoz kapcsolt anti-F4/80 vagy izotípus kontroll antitestekkel festettük, majd áramlási citometriás mérés következett. Az ábrán (a) Vt(Syk) és $S^{-/-}$kimérákból származó sejtek, valamint (b) Vt(CARD9) és 
CARD9-/ kimérákból származó sejtek diagramjai láthatók. All: az összes mért sejt; \%Gated: az adott kapun belülre eső sejtek aránya az összes mért sejt százalékában; doublepos: a dupla pozitív sejtek; Intensity_MC_Ch02: Alexa Fluor® 488-ból származó fluoreszcencia intenzitás; Intensity_MC_Ch03: PE eredetű fluoreszcencia intenzitás.

\section{V.5.3. A makrofágok és Candida sejtek koinkubációja (fertőzés)}

A makrofágok és Candida sejtek koinkubációját Tóth és mtsai. (2017) alapán a következő módon végeztük. Két nappal a kísérletek előtt táptalajról $2 \mathrm{ml}$ YPD tápoldatba oltottuk a Candida sejteket, majd $30^{\circ} \mathrm{C}$-on egy éjszakán át rázattuk azokat. A következő napon az így nyert szuszpenzióból $200 \mu$ l-t 2 ml YPD tápoldatba mértünk, melyet ismét $30{ }^{\circ} \mathrm{C}$-on egy éjszakán keresztül történő rázatás követett. A kísérletek napján a folyadékkultúrákat centrifugáltuk (3000 RPM, 9-es gyorsulási és lassulási fokozat, 5 perc, Heraeus Multifuge 3 S$\mathrm{R}$ centrifuga), majd eltávolítottuk a felülúszót és $2 \mathrm{ml}$ PBS-ben szuszpendáltuk az élesztősejteket. Ezt további két mosási lépés követte, végül 1,5 ml PBS-ben szuszpenzióba vittuik a sejteket. A sejtkoncentrációkat Bürker-kamra segítségével határoztuk meg, majd kiegészített DMEM tápoldattal a kívánt értékre állítottuk. Ezt az ún. MOI (multiplicity of infection, fertőzési arány) határozta meg, mely megadja, hogy a fertőzés során hány élesztősejt jut egy makrofágra (pl. MOI 5:1 esetén 5 gombasejt jut egy makrofágra). Az egy tenyésztőhelyben található makrofágok számát mikroszkópiával becsültük az átlagos sejtszám/látómező érték és a tenyésztőhelyek területe alapján. Végül a kísérlet típusától függő végtérfogatú kiegészített DMEM tápoldatban fertőztük a makrofágokat. A kontroll makrofágokon tápoldatot cseréltünk.

Amennyiben egy adott kísérletnél az itt bemutatott folyamattól eltértünk, azt a megfelelő leírásánál jeleztük.

\section{V.5.4. Az NF-кB nukleáris transzlokációjának vizsgálata}

A makrofágokat 12 lyukú tenyésztő lemezekben fertőztük $C$. parapsilosis törzsekkel MOI 5:1 dózisban, $1 \mathrm{ml}$ végtérfogatban. A negatív kontroll sejteken tápoldatcsere történt, a pozitív kontroll kezeléshez $1 \mu \mathrm{g} / \mathrm{ml}$ lipopoliszzacharid (LPS) tartalmú kiegészített DMEM tápoldatot mértünk a tenyészetre. Ezután 1,5 h inkubáció következett, melynek vége előtt 15 perccel a sejteket fedő médiumba DRAQ5 ${ }^{\mathrm{TM}}$ fluoreszcens sejtmagfestéket adtunk 2,5 $\mu \mathrm{M}$ végkoncentrációban. Az inkubáció után a makrofágokról leszívtuk a tápoldatot, majd a tenyésztőhelyeket kétszer mostuk $500 \mu \mathrm{l}$ PBS-sel. A tenyésztőlyukakba ez után $350 \mu \mathrm{l}$ TrypLE ${ }^{\mathrm{TM}}$ Express Enzyme oldatot mértünk, melyet 5 perc $37^{\circ} \mathrm{C}$-on történő inkubáció követett. 
Tenyésztőhelyenként 400-400 $\mu 1$ FBS-PBS-sel vittük szuszpenzióba a sejteket és mikrocentrifuga csövekbe mértük azokat. A csöveket 5 percen át centrifugáltuk 2000 RPM beállítással, Heraeus Pico 17 mikrocentrifugában. A további lépésekhez az R\&D Systems intracelluláris fehérjék immunfestéséhez javasolt protokollja (https://www.rndsystems.com/resources/protocols/flow-cytometry-protocol-staining-

intracellular-molecules-using-detergents) volt irányadó. A felülúszók eltávolítása után $300 \mu 1$ 4\%-os PFA-PBS-t mértünk a sejtpelletekre, melyeket rázókészülék segítségével szuszpendáltunk. Tíz perces, szobahőmérsékleten és fénytől elzárt módon történő inkubációt követően ismét centrifugáltuk a mikrocentrifuga csöveket. A felülúszókat leöntöttük, majd két mosási lépés következett csövenként $200 \mu$ 1 PBS-sel. A pelleteket 100-100 $\mu 1$ Triton X-PBSben szuszpendáltuk, majd 5-5 $\mu$ l Alexa Fluor ${ }^{\circledR}$ 488-cal konjugált anti-NF- $\kappa B$ p65 antitestoldatot adtunk azokhoz. Fénytől védve 30 percig szobahőmérsékleten hagytuk a sejteket. Centrifugálás és a felülúszók eltávolítása után újabb két mosási lépés következett. A $100 \mu \mathrm{l}$ PBS-ben szuszpendált sejtekről az Amnis FlowSight ${ }^{\circledR}$ Imaging Flow Cytometer segítségével készítettünk mikroszkópos felvételeket fehér fény, $488 \mathrm{~nm}$ és $642 \mathrm{~nm}$ hullámhosszú lézeres megvilágítás mellett. Ekkor az Alexa Fluor® 488 eredetű emisszió a második csatornán (Ch02), míg a DRAQ5 ${ }^{\mathrm{TM}}$-ből származó fluoreszcencia a tizenegyedik csatornán (Ch11) volt detektáltható (7. ábra). Azon makrofágok százalékos arányát, melyekben

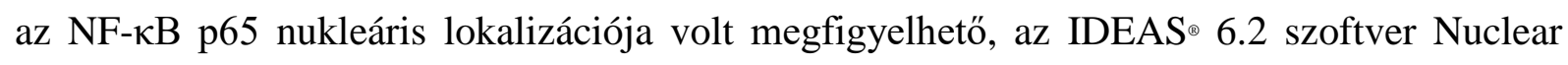
Localization Wizard algoritmusának segítségével határoztuk meg.

\section{V.5.5. Citokinprofil vizsgálata Proteome Profiler segítségével}

Többféle citokin egyidejü kimutatására az R\&D Systems Proteome Profiler Mouse Cytokine Array Panel A Kitjét használtuk. A kezelések megkezdése előtt a sejteket kiegészített DMEM tápoldattal egyszer mostuk, hogy a BMDM-médiumból visszamaradó L929 eredetű citokineket eltávolítsuk. A mérendő minták előállításához 24 lyukú tenyésztő lemezben $C$. parapsilosis GA1 törzzsel koinkubáltunk BMDM-eket MOI 5:1 arányban, $500 \mu \mathrm{l}$ végtérfogatban, 24 h-ig. A kontroll sejteken tápoldatot cseréltünk. A felülúszókat mikrocentrifuga csövekbe gyüjtöttük és centrifugáltuk (3000 RPM, 5 perc, Heraeus Pico 17 mikrocentrifuga). A felülúszókat további felhasználásig $-80^{\circ} \mathrm{C}$-on tartottuk.

A méréseket legalább 3 független kísérletből és azonos kezelésből származó poolozott mintákon végeztuik el a gyártó utasításai alapján a következő módon (https://resources.rndsystems.com/pdfs/datasheets/ary006.pdf). A membránokat 1 órán 
a

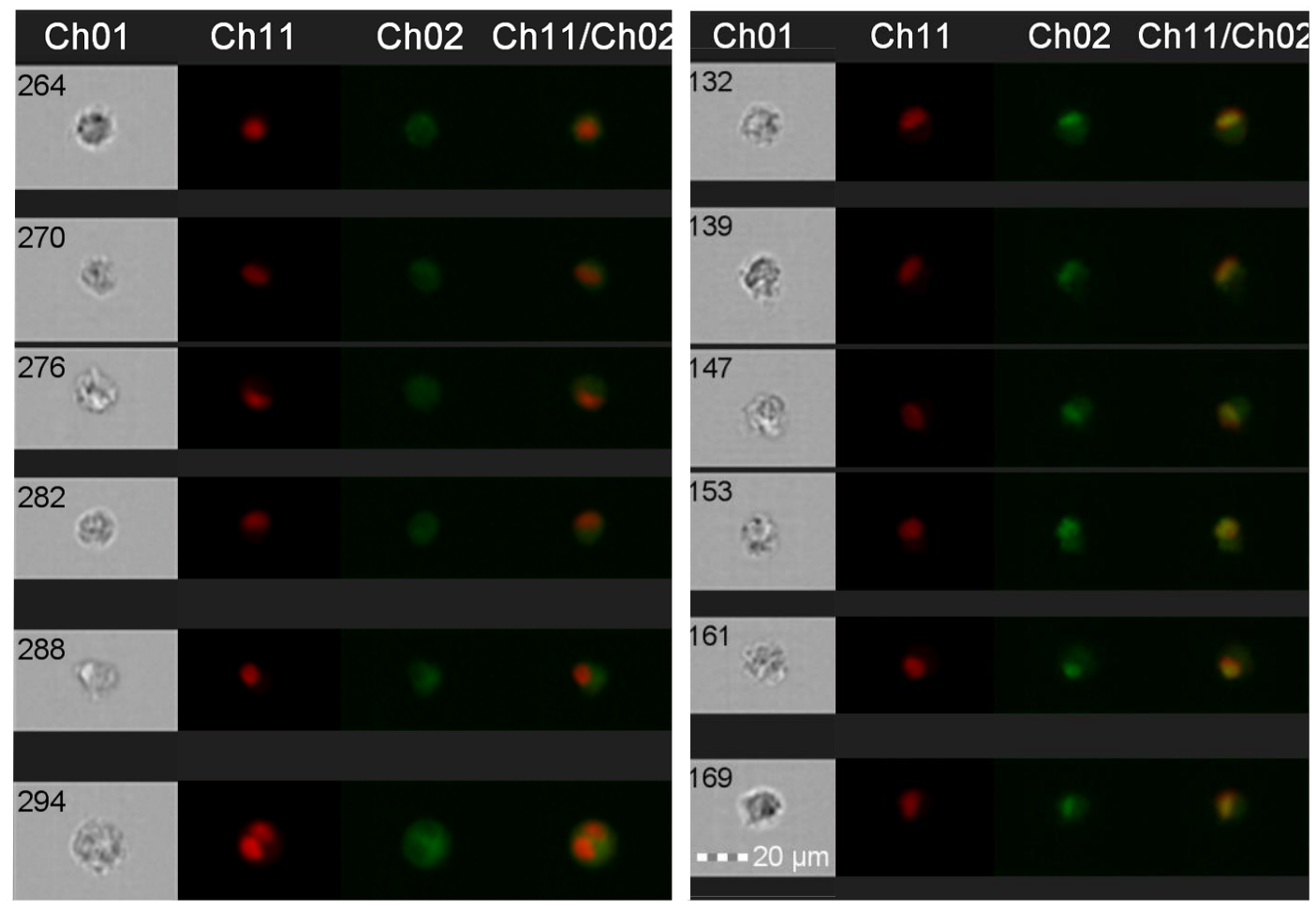

7. ábra. Reprezentatív felvételek random sorrendben lemért Alexa Fluor® 488-cal konjugált anti-NFкB p65 antitesttel és DRAQ5 ${ }^{\mathrm{TM}}$ sejtmag festékkel jelölt BMDM-ekröl. Az ábrákon (a) kontroll és (b) 1 $\mu \mathrm{g} / \mathrm{ml}$ LPS-el 1,5 h-ig kezelt makrofágok láthatók. Előbbi esetben az NF-кB p65 alegysége citoplazmás elhelyezkedésü, míg az utóbbi esetben a sejtmagokban halmozódott fel. Ch01: fénymikroszkópos képek; Ch02: az Alexa Fluor ${ }^{\circledR} 488$ detektálására használt csatorna; Ch11: és DRAQ5 ${ }^{\mathrm{TM}}$ detektálására használt csatorna; Ch11/Ch02: a Ch011 és a Ch02 fúziója.

keresztül 2 mL Array Buffer 6-tal blokkoltuk billenő rázógépen. A folyadék eltávolítása után a membránokra mértük a felülúszómintákat tartalmazó keverékeket $(700 \mu 1$ poolozott felülúszóminta $+500 \mu 1$ Array Buffer $4+300 \mu 1$ Array Buffer $6+15 \mu 1$ Mouse Cytokine Array Panel A Detection Antibody Cocktail). Ezt egy éjszakás $4{ }^{\circ} \mathrm{C}$-on történő inkubáció követte billenő rázógépen. A membránokat ezután háromszor 10 percig mostuk 20-20 ml 1×Wash Buffer-ben. Végül membránonként $2 \mathrm{ml}$ tormaperoxidáz-sztreptavinin konjugátummal kiegészített Array Buffer 6-ot mértünk rájuk, és 30 percig szobahőmérsékleten rázattuk őket. Ezt ismét háromszori mosás követte. Az 1×Wash Buffer leszívása után Chemi Reagent Mixet rétegeztünk a membránokra. Egy perc elteltével a mixet eltávolítottuk a membránokról. A kemilumineszcens szignálokat a C-DiGit Blot Scanner (LI-COR) készülék segítségével detektáltuk és az Image Studio Digits szoftver 3.1. verziójával vizualizáltuk. 


\section{V.5.6. Citokinek mennyiségi meghatározása enzimkötött immunoszorbens próba (ELISA) segítségével}

A minták elöállításához $C$. parapsilosis törzsekkel MOI 5:1 és a $C$. albicans törzzsel MOI 1:25 arányban fertőztük a makrofágokat, 24 h koikubációs idővel. A BMDM-eket 24 lyukú tenyésztőlemezben, tenyésztőhelyenként $500 \mu$ l végtérfogatban, míg a PM-eket 96 lyukú lemezekben, tenyésztőhelyenként $200 \mu \mathrm{l}$ végtérfogatban kezeltük. A kontroll sejteken tápoldatot cseréltünk. A BMDM-ek esetén a kezelések megkezdése előtt a tenyésztőhelyeket kiegészített DMEM tápoldattal egyszer mostuk. A kísérletek lejártakor a felülúszókat összegyüjtöttük, centrifugáltuk, majd további felhasználásig fagyasztva tároltuk.

A felülúszókból TNF $\alpha, \mathrm{KC}, \mathrm{MIP} 1-\alpha$ és MIP-2 citokineket határoztunk meg szendvics ELISA módszerrel. Ehhez az alábbi kiteket alkalmaztuk a gyártó (R\&D Systems) utasításai szerint: Mouse TNF-alpha DuoSet ELISA (katalógusszám: DY410), Mouse CXCL1/KC DuoSet ELISA (katalógusszám: DY453), Mouse CCL3/MIP-1 alpha DuoSet ELISA (katalógusszám: DY450) és Mouse CXCL2/MIP-2 DuoSet ELISA (katalógusszám: DY452).

A mérést röviden a következő módon végeztük. A PBS-ben hígított elsődleges antitestek felvitele (100 $\mu 1 /$ mintahely) után a lemezeket egy éjszakán át szobahőmérsékleten hagytuk, majd mosópufferrel négyszer mostuk, és BSA-tartalmú blokkoló puffert (200 $\mu 1 /$ mintahely) mértünk beléjük. Min. 1 óra elteltével, ismét négy mosást követően a felülúszókat Reagent Diluent pufferben hígítottuk, majd ezekből 100-100 $\mu 1$-t mértünk a lemezek mintahelyeibe. A standardokból Reagent Diluent oldatban 7 lépcsős hígítási sort készítettünk, és duplikátumban 100-100 $\mu$ l-t vittünk fel a hígítási tagokból a lemezekre. Negatív kontrollként a Reagent Diluent puffer szolgált. Két óra inkubáció után, újabb négy mosást követően bemértük a Reagent Diluent oldatban hígított másodlagos antitesteket a lemezekbe (100 $\mu 1$ /mintahely). Ismételt 2 óra elteltével a lemezeket négyszer mostuk, a mintahelyekbe Reagent Diluent oldatban hígított sztreptavidin-tormaperoxidáz oldatot mértünk, és a lemezeteket 20 percig fénytől elzárva tartottuk. A következő négy mosás után 100-100 $\mu$ l szubsztrát oldatot mértünk a mintahelyekbe és fénytől védett helyre tettük a lemezeket. A színreakciókat 1,8 Mos kénsavoldattal (50 $\mu \mathrm{l} /$ mintahely) állítottuk le. Végül a SPECTROstar Nano Microplate Reader készülék (BMG Labtech) segítségével mértünk abszorbanciát 450 nm-en. Az adatokat MARS Data Analysis szoftverrel analizáltuk.

\section{V.5.7. A Candida sejtek makrofágok általi fagocitózisának vizsgálata}

A vizsgálathoz a makrofágokat fluoreszcens Alexa Fluor® 488 szukcinimidil észterrel jelölt vagy a GFP-CLIB214 Candida sejtekkel MOI 5:1 arányban fertőztünk 12 mintahelyü 
lemezekben. A C. parapsilosis törzsek esetén 15 perc (BMDM, PM), 1 h (PM) és 2 h (BMDM), míg a $C$. albicans törzs esetén 15 és 30 (BMDM, PM) perc koinkubációs időket hagytunk.

A gombák jelölése és a kísérletek Tóth és mtsai. (2017) alapján a következő módon alakultak. A V.5.3. részben leírtak szerint tenyésztett és mosott Candida sejteket $500 \mu$ l PBSben szuszpendáltuk. Ezen szuszpenzió $200 \mu$ l-éhez $22 \mu 1 \mathrm{Na}_{2} \mathrm{CO}_{3}$ oldatot (1 M), majd $4 \mu \mathrm{l} 1$ mg/ml koncentrációjú Alexa Fluor® 488 szukcinimidil észter törzsoldatot kevertünk. Ezt alapos összerázás és egy órás szobahőmérsékleten történő inkubáció követték, fénytől elzárva. Ezután a sejteket háromszor mostuk 1-1 ml PBS-el (3000 RPM, 5 perc, Heraeus Pico 17 mikrocentrifuga). A sejtpelletet $200 \mu \mathrm{l}$ PBS-ben szuszpendáltuk, meghatároztuk a sejtkoncentrációt és megfertóztük a makrofágokat, illetve a kontroll sejteken tápoldatot cseréltünk. Az inkubációs idők leteltével a kokultúrákról leszívtuk a felülúszókat, és a sejteket kétszer mostuk PBS-el. A makrofágokra mintahelyenként $350 \mu 1$ TrypLE ${ }^{\mathrm{TM}}$ Express Enzyme oldatot adagoltunk. Öt perc $\left(37^{\circ} \mathrm{C}\right)$ elteltével $400 \mu$ FBS-PBS bemérése után szuszpendáltuk és mikrocentrifuga csövekbe helyeztük a makrofágokat. Centrifugálás után (2000 RPM, 5 perc, Heraeus Pico 17 mikrocentrifuga) a felülúszókat leöntöttük, majd $100 \mu$ l PBS-ben vettük fel a sejteket. A szinglet makrofágokat az Amnis FlowSight@ Imaging Flow Cytometer képalkotó áramlási citométerrel vizsgáltuk fehér fényes megvilágítás és $488 \mathrm{~nm}$ hullámhosszú lézeres gerjesztés mellett. A készülék második csatornáján (Ch02) detektáltuk a Candida sejtek által kifejezett GFP-ből vagy az Alexa Fluor® 488-ból származó jelet. Az adatok analízisét az IDEAS 6.2 szoftverrel végeztuik. A megfelelő genotípusú fertőzetlen kontroll sejtek Ch02-n azonosított autofluoreszcenciájának tartományát tekintettük negatívnak, míg az attól magasabb értékeket adó makrofágokat határoztuk meg fagocitózis pozitív sejteknek (8.b ábra). A készülékkel minden makrofágról mikroszkópos felvételt készítettünk (8.a ábra), melyek alapján a szoftver Spot Count funkciójának segítségével meghatároztuk az egy makrofág által bekebelezett élesztősejtek számát.

\section{V.5.8. Élesztősejtet tartalmazó fagoszómák savasodásának vizsgálata makrofágokban}

A kísérlet kivitelezéséhez Papp és mtsai. (2018) munkáját vettük alapul. A makrofágokat Alexa Fluor@ 488 szukcinimidil észterrel, valamint pHrodo $^{\mathrm{TM}}$ Red fluoreszcens festékekkel szimultán festett Candida sejtekkel vagy pHrodo ${ }^{\mathrm{TM}}$ Reddel jelölt GFP-CLIB214 törzzsel fertőztük 12 lyukú sejttenyésztő lemezben, MOI 5:1 beállítással, 15 percig. A pHrodo $^{\mathrm{TM}}$ Red megfelelő beállítás mellett az intracelluláris savas kompartimentumokban intenzív fluoreszcenciát mutat (https://www.thermofisher.com/order/catalog/product/P36600). 
a

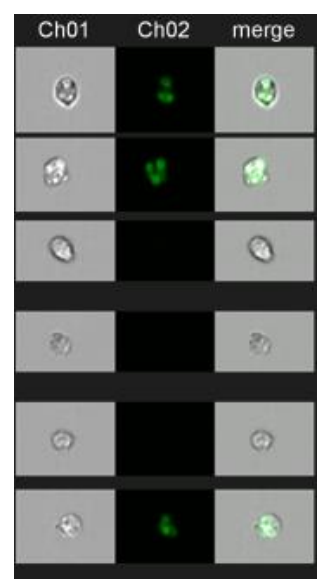

b

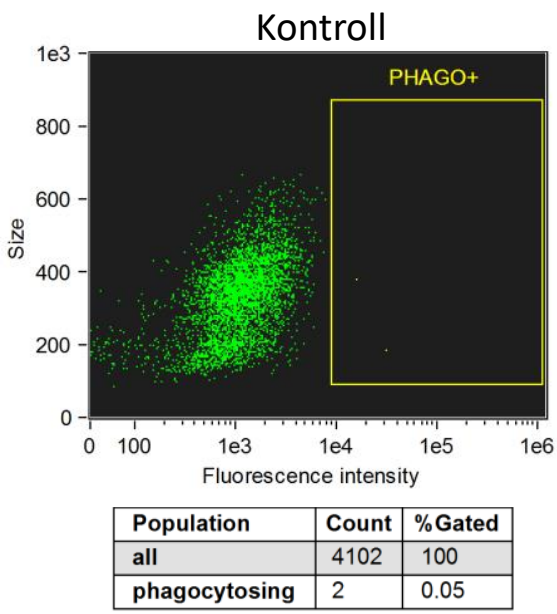

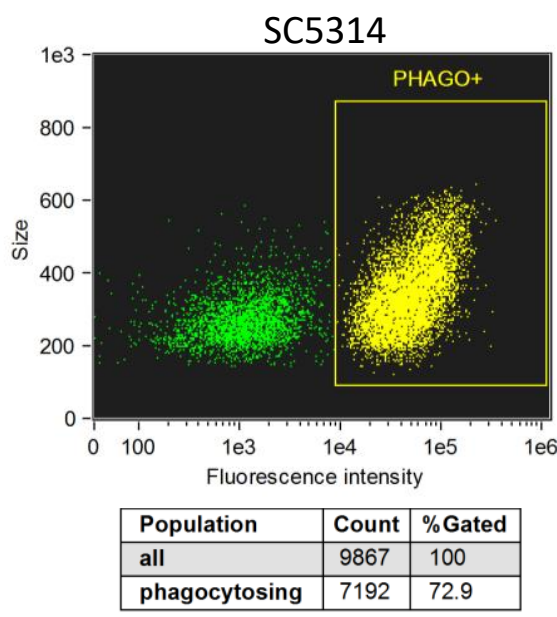

8. ábra. (a) Reprezentatív képek Alexa Fluor® 488 szukcinimidil észterrel festett $C$. albicans SC5314 törzzsel fertőzött PM-ekről képalkotó áramlási citometriát követően. Ch01: fénymikroszkópos képek; Ch02: az Alexa Fluor ${ }^{\circledR} 488$ detektálására használt csatorna; merge: a Ch01 és a Ch02 fúziója. (b) A kapuzás sémája fertőzetlen kontroll és a $C$. albicans SC5314 törzsével fertőzött PM-ek mérését követően. Size: méret; Fluorescence intenstity: az Alexa Fluor ${ }^{\circledR}$ 488-ból származó fluoreszcencia intenzitás; all: összes mért sejt; phagocytosing és PHAGO+: a fagocitáló sejtek; Count: az adott populáción belüli sejtek száma; \%Gated: az adott kapun belüli sejtek az összes mért sejt \%-ában.

Az YPD tápoldatban felszaporított élesztőtenyészeteket HBSS pufferben kétszer mostuk, majd $500 \mu 1$ HBSS-ben szuszpendáltuk őket. A szuszpenzió $200 \mu$ l-jéhez $22 \mu 1 \mathrm{Na}_{2} \mathrm{CO}_{3}$ oldatot (1 M), majd 4 l $1 \mathrm{mg} / \mathrm{ml}$ koncentrációjú Alexa Fluor ${ }^{\circledR} 488$ szukcinimidil észter törzsoldatot, végül $10 \mu \mathrm{pHrodo}{ }^{\mathrm{TM}}$ Red $(1 \mathrm{mM})$ oldatot adtunk. A GFP-CLIB214 törzs esetén az Alexa Fluor® 488 szukcinimidil észter bemérését kihagytuk. Keverést követően egy órás szobahőmérsékleten történő inkubációt hagytunk, fénytől elzárva. A további mosásokat, a fertőzési lépéseket, a makrofágok méréshez való előkészítését a V.5.7. alfejezetben közölt módon kiviteleztük. A szinglet makrofágokat a FlowSight ${ }^{\circledR}$ Imaging Flow Cytometer készülékkel monitoroztuk fehér fény és $488 \mathrm{~nm}$ hullámhosszú lézeres gerjesztés mellett. Az Alexa Fluor ${ }^{\circledR} 488$ (illetve a GFP) és a pHrodo $^{\mathrm{TM}}$ Red emissziós spektrumainak átfedését a fluorofórok együttes elemzését lehetővé tévő kompenzációs mátrix segítségével küszöböltük ki. Ekkor az Alexa Fluor® 488 és a GFP eredetü emisszió a második csatornán (Ch02), míg a pHrodo ${ }^{\mathrm{TM}}$ Redből származó fluoreszcencia a negyedik csatornán (Ch04) volt detektálható (9. ábra). Az adatokat az IDEAS ${ } 6.2$ szoftverrel értékeltük ki. Az azonos genotípusú fertőzetlen kontroll sejtek autofluoreszcenciáját tekintettük negatívnak, míg az attól magasabb értékeket adó makrofágokat pozitívnak. A fagoszómák savasodásának hatékonyságát az alábbi képlet alapján számoltuk: 


\begin{tabular}{|c|c|c|c|c|c|c|c|}
\hline Ch01 & Ch02 & Ch04 & merged & Ch01 & Ch02 & Ch04 & merged \\
\hline $\begin{array}{l}125 \\
-13 \\
-20\end{array}$ & A & & (2) & $\begin{array}{r}12151 \\
20 \mu n\end{array}$ & Q & $\boldsymbol{\nabla}$ & 8 \\
\hline
\end{tabular}

9. ábra. Reprezentatív felvételek Alexa Fluor ${ }^{\circledR} 488$ szukcinimidil észterrel és pHrodo ${ }^{\mathrm{TM}}$ Reddel szimultán festett $C$. parapsilosis sejtekkel fertőzött BMDM-ekről az Amnis FlowSight ${ }^{\circledR}$ Imaging Flow Cytometerrel történő mérést követően. Az ábrán (a) Alexa $488^{+}$pHrodo $^{\mathrm{TM}}$ Red $^{-}$és (b) Alexa488 ${ }^{+}$ pHrodo $^{\mathrm{TM}} \mathrm{Red}^{+}$sejtek láthatók. Ch01: fénymikroszkópos képek; Ch02: az Alexa Fluor ${ }^{\circledR} 488$ detektálására használt csatorna; Ch04: a pHrodo ${ }^{\mathrm{TM}}$ Red detektálására használt csatorna; merged: a Ch01, Ch02 és Ch04 fúziója.

(pHrodo ${ }^{\text {TM }}$ Red $^{+}$sejtek az összes mért sejt \%-ában/ Alexa Fluor ${ }^{\circledR} 488^{+}$sejtek az összes mért sejt \%-ában) $\times 100 \%$.

\section{V.5.9. A C. parapsilosis makrofágok általi eliminációjának vizsgálata}

A makrofágok C. parapsilosist elpusztító képességét Németh és mtsai. (2013) alapján élőcsíraszám meghatározás segítségével állapítottuk meg. A BMDM-eket 24 lyukú tenyésztőlemezben, tenyésztőhelyenként $500 \mu$ l végtérfogatban, míg a PM-eket 96 lyukú lemezekben, tenyésztőhelyenként $200 \mu$ l végtérfogatban fertőztük MOI 5:1 dózisban. A gombák 100\% túlélési értékének meghatározásához gombával inokulált, de makrofág nélküli kontroll tenyésztőhelyeket alkalmaztunk. Kezelésenként 3 technikai párhuzamossal (tenyésztőhellyel) dolgoztunk. Három óra elteltével a tenyésztőlemezekből rázás után mikrocentrifuga csövekbe mértük a felülúszókat, és steril desztillált vizet pipettáztunk a tenyésztőhelyekbe (BMDM-ek és megfelelő a kontroll kezelések esetén 400 ㅆ-t, míg PM-ek és a megfelelő kontrollok esetén $150 \mu \mathrm{l}-\mathrm{t})$. Öt perc inkubáció után a tenyésztőhelyekben lévő desztillált vízzel intenzíven mostuk azokat, és tartalmukat a megfelelő mikrocentrifuga csövekben levő felülúszókhoz adtuk, majd ismét desztillált vizet adtunk a tenyésztőhelyekbe (BMDM-ek és kontrolljaik esetén $300 \mu$ l-t, míg PM-ek és kontrolljaik esetén $150 \mu$ l-t). Újabb mosás után ezt is a megfelelő mikrocentrifuga csövekbe juttattuk. Az így előállított szuszpenziókat 29G-s injekciós tün keresztül ötször felszívtuk és visszapréseltük a csövekbe. A szuszpenziókat PBS-sel hígítottuk, majd 100-100 $\mu$ l-jeit triplikátumban YPD táptalajra szélesztettük. Két nap $30^{\circ} \mathrm{C}$-on történő inkubáció után meghatároztuk az élő csíraszámot 
(colony-forming unit, $\mathrm{CFU}$ ). Az élesztősejtek makrofágok általi eliminációjának hatékonyságát az alábbi képlet segítségével számoltuk ki:

$$
\left.\left(\mathrm{CFU}_{\text {kontroll }}-\mathrm{CFU}_{\text {fertőzött }}\right) / \mathrm{CFU} \text { kontroll }\right) \times 100 \% \text {, }
$$

ahol a CFU kontroll a makrofágmentes kontroll kezelésekhez tartozó CFU-k átlagos száma, a CFU fertőzött pedig a fertőzött makrofágok kezeléseihez tartozó CFU-k átlagos száma.

\section{V.5.10. Gombakolonizáció mértékének meghatározása különböző szövetekből CFU meghatározással}

A fertőzött rágcsálók szerveinek és vérének kolonizáltságát is élő csíraszám meghatározással végeztük. Ehhez a gombákat az V.5.3. fejezetben leírtaknak megfelelően mostuk és számoltuk, majd PBS segítségével a megfelelő sejtkoncentrációra állítottuk a szuszpenziókat. Saját tapasztalataink és irodalmi adatok alapján (pl. Gross és mtsai. 2009, Drummond és mtsai. 2015) az állatokat a laterális farokvénán keresztuil oltottuk be $C$.

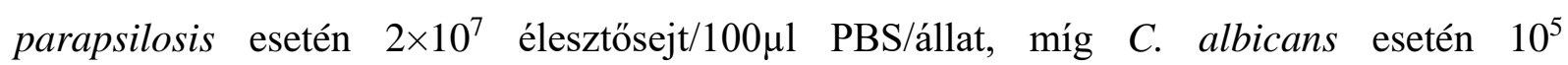
élesztősejt/100 $\mu 1$ PBS/állat dózisokkal. Az előbbi esetben 2, 5, 7 és 30 nap, az utóbbi faj esetén 2 nap elteltével dolgoztuk fel az állatokat. Vért vettünk a szemzug vénás plexusából vagy a hátulsó üresvénából, majd ebből $50 \mu$ l-t YPD táptalajra szélesztettünk. Kiboncoltuk a lépeket, a veséket, a májakat és az agyakat, tömegüket lemértük, majd 2-2 ml PBS-ben TT-30K Digital Handheld Homogenizer segítségével homogenizáltuk azokat. A tömény vagy PBS-sel hígított homogenizátumokból 100-100 $\mu$ l-t YPD táptalajra szélesztettünk triplikátumban. Két nap $30^{\circ} \mathrm{C}$-on történő inkubáció után megszámoltuk a megjelent telepeket, mely alapján meghatároztuk a CFU-k mennyiségét a szervek egységnyi tömegére vagy a vér egységnyi térfogatára nézve.

\section{V.5.11. Hisztológia}

Az egereket az V.5.10. fejezetben leírtak szerint fertőztük C. parapsilosisszal vagy C.albicansszal. Az állatok veséjét 2 és 30 nap múlva kiboncoltuk, majd 4\%-os PFA-PBS-ben fixáltuk. Ezekből az SZTE Pathologiai Intézete munkatársai készítettek hematoxilin-eozin (HE) és/vagy PAS festett szövettani metszeteket.

\section{V.5.12. Diagramok és statisztika}

A diagramokat és statisztikai elemzéseket a GraphPad Prism 6 szoftverrel készítettuik. Páros t-próbát (in vitro kísérletek), Mann-Whitney próbát (gombakolonizáció meghatározása) 
alkalmaztunk. Statisztikailag szignifikánsnak tekintettük azokat az eseteket, ahol p<0,05 volt. A diagramokon az átlagok és a szórások kerültek feltünetésre. 


\section{Eredmények és értékelésük}

\section{VI.1. Az NF-кB nukleáris transzlokációja Syk- és CARD9-függő a $C$. parapsilosisszal fertőzött BMDM-ekben}

Az NF- $\mathrm{B}$ klasszikus aktivációja a veleszületett gombaellenes immunválasz fontos eleme. Ennek során p65-p50 és p65-c-Rel dimerek transzlokálódnak a sejtmagba, és megindítják a célgének (pl. citokinek, defenzinek génjei) transzkripcióját (Romani 2011, Drummond és mtsai. 2014, Verma és mtsai. 2014, Dambuza és mtsai. 2017, Lonakis és mtsai. 2017). Duan és mtsai. (2017) THP-1 humán makrofágszerü sejtekben mutatták ki, hogy a transzlokáció $C$. parapsilosis fertőzés hatására is megtörténhet. Nem ismert azonban, hogy az NF-кB C. parapsilosis fertőzés által kiváltott aktivációja a Syk vagy a CARD9 szabályozása alatt áll-e.

Ennek tesztelésére $C$. parapsilosis törzsekkel (GA1, CLIB214 és CDC317) fertőztünk $\mathrm{Vt}(\mathrm{Syk}), \mathrm{Syk}^{-/-}, \mathrm{Vt}(\mathrm{CARD9})$ és CARD9-/- kiméra egerekből tenyésztett BMDM-eket, majd immunfestéssel jelöltük az NF-кB p65 alegységet, és képalkotó áramlási citométerrel készített mikroszkópos felvételek alapján meghatároztuk p $65^{+}$sejtmagú makrofágok százalékos arányát. Fertőzetlen negatív kontroll sejteket és LPS-stimulált pozitív kontroll makrofágokat is alkalmaztunk. A C. parapsilosis törzsekkel fertőzött Syk $^{-/-}$makrofágokban alacsonyabb arányban tapasztaltuk a p65 magi transzlokációját, mint a $\mathrm{Vt}(\mathrm{Syk})$ sejtekben [ $\mathrm{Vt}(\mathrm{Syk}): \mathrm{GA} 1$ : 21,46\%; CLIB214: 24,17\%; CDC317: 22,95\%; Syk $^{-1-}$ : GA1: 9,9\%; CLIB214: 16,42\%; CDC317: 14,02\%; 10.a, c ábra]. Ehhez hasonlóan C. parapsilosisszal történő koinkubáció után a $65^{+}$sejtmagú sejtek aránya a CARD9-/- BMDM-ek esetén kisebb volt, mint Vt(CARD9) makrofágok esetében [VtCARD9: GA1: 31,79\%; CLIB214: 28,82\%; CDC317: 30,4\%; CARD9 ${ }^{-/}:$GA1: 16,1\%; CLIB214: 21,61\%; CDC317: 12,82\%; 10.b, d ábra]. Az LPS genotípustól függetlenül a makrofágok több mint 60\%-ában kiváltotta az NF-кB p65 sejtmagi transzlokációját (10.a,b,c,d ábra).

Az adatok alapján azt a következtetést vontuk le, hogy a C. parapsilosis fertőzést követő NF-kB aktiváció BMDM-ekben Syk- és CARD9-függő. Ez összhangban van korábbi kutatásunkkal, amelyben a $C$. parapsilosisszal kezelt makrofágszerü sejtek pro-IL-1 $\beta$ termelése

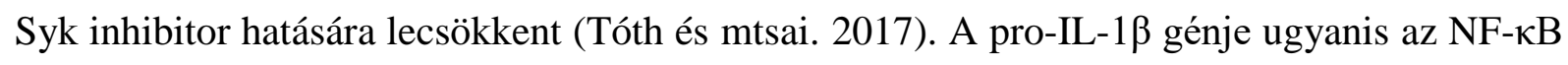
szabályozása alatt áll (Goto és mtsai. 1999). A C. albicans is képes NF-кB aktivációt előidézni különböző sejttípusokban (Roeder és mtsai. 2004, Moyes és mtsai. 2010, Jia és mtsai. 2014, 

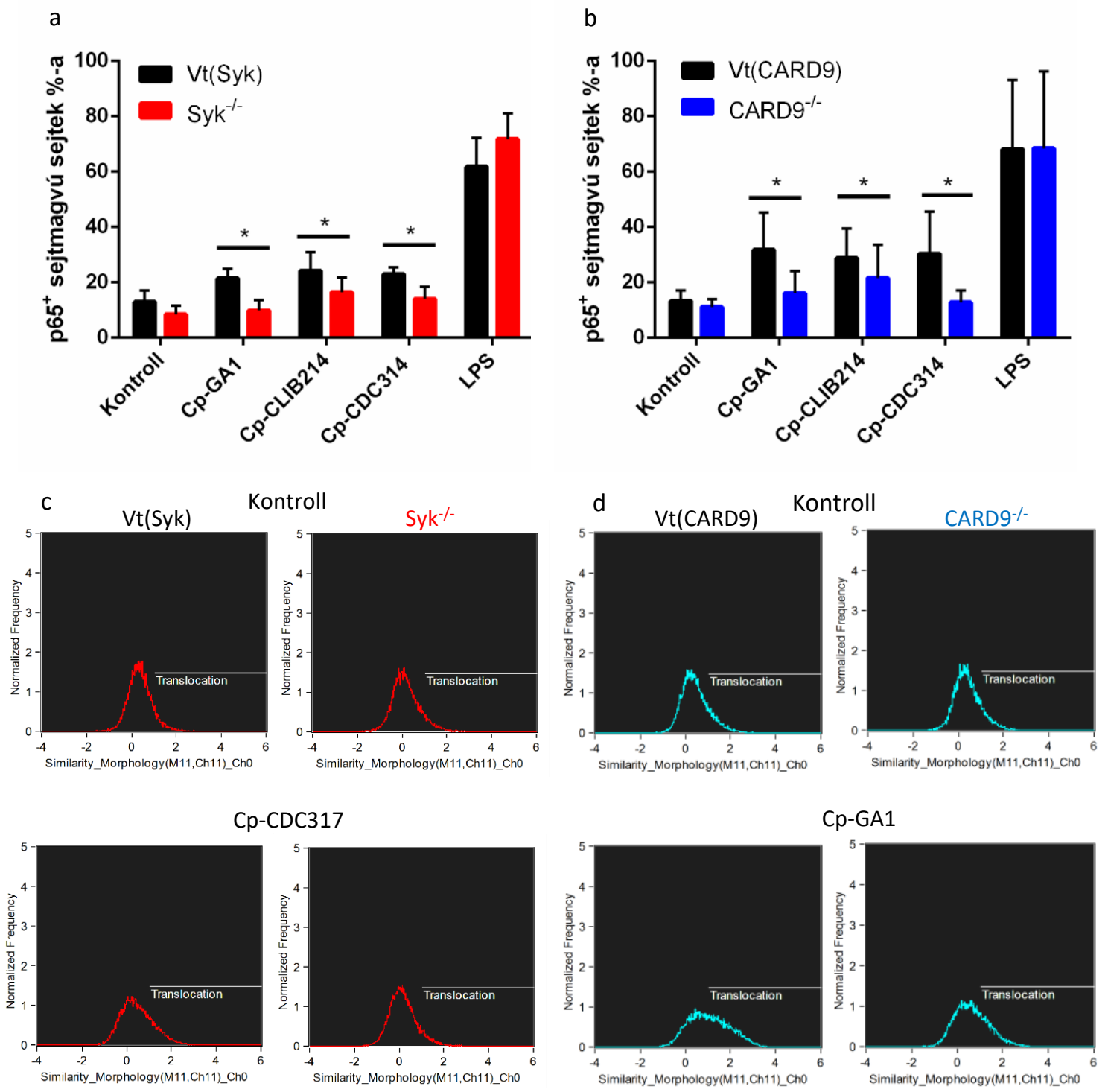

$$
\text { LPS }
$$
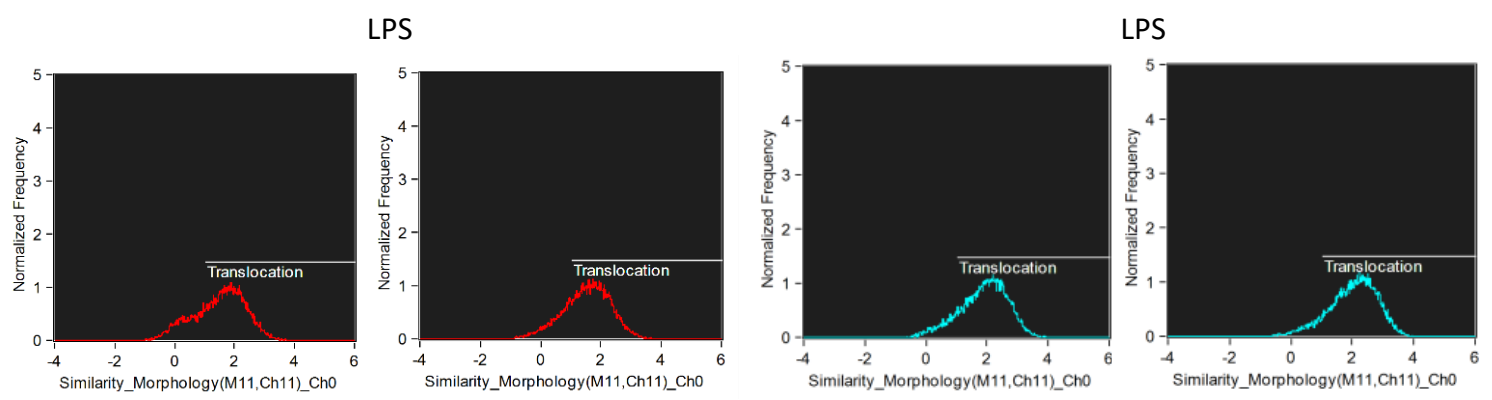

10. ábra. Az NF-кB p65 magi transzlokációja. A BMDM-eket C. parapsilosisszal (GA1, CLIB214 és CDC317 törzsek, MOI 5:1) vagy LPS-sel (1 $\mu \mathrm{g} / \mathrm{ml})$ kezeltuik 90 percig. A sejtmagokat DRAQ5 ${ }^{\mathrm{TM}}$-tel, az NF-кB p65-öt Alexa Fluor® 488-cal konjugált antitesttel festettük. A sejteket képalkotó áramlási citométerrel detektáltuk. (a) Vt(Syk) és Syk ${ }^{-/}$illetve (b) Vt(CARD9) és CARD9-- kimérákból származó p65 ${ }^{+}$sejtmagvú BMDM-ek százalékos aránya (átlag \pm standard deviáció). (c) Vt(Syk) és Syk ${ }^{-/-}$, valamint (d) Vt(CARD9) és CARD9-- kimérákból származó BMDM-ekhez tartozó reprezentatív hisztogramok. A „Translocation” régió jelöli a p65+ sejtmagvú sejtpopulációkat. Cp-: C. parapsilosis. n $\geq 4$. *: p<0,05 (páros t-próba). 
Roth és mtsai. 2016), amely a fertőzött CARD9-/- BMDM-ekben szintén alulmúlta a Vt makrofágokét (Bi és mtsai. 2010). Egy másik vizsgálatban pedig curdlannal ( $\beta$-glükán

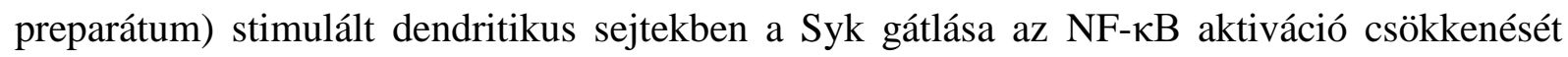
okozta (Gringhuis és mtsai. 2009). Megjegyzendő, hogy míg mi élő gombasejtekkel dolgoztunk, addig a C. albicans indukálta NF-אB aktiváció CARD9 függését, valamint a p65 C. parapsilosis kiváltotta magi transzlokációját bemutató közleményekben hővel elölt gombákat használtak fel (Bi és mtsai. 2010, Duan és mtsai. 2017). Továbbá, a főként TLR4-en keresztül szignalizáló LPS által kiváltott magi transzlokációt Bi és mtsai. (2010) eredményeihez hasonlóan Syk- és CARD9-függetlennek tapasztaltuk.

\section{VI.2. Az egér makrofágok $C$. parapsilosis fertôzés során kiváltott citokinválasza a Syk és a CARD9 által szabályozott folyamat}

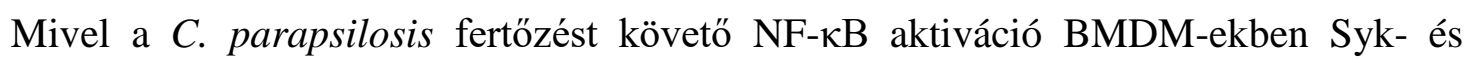
CARD9-függőnek bizonyult, feltételeztük, hogy a C. parapsilosisszal fertőzött makrofágok citokintermelése is részben Syk és CARD9 által szabályozott. Ezért összehasonlítottuk a $C$. parapsilosszal stimulált Vt(Syk) és Syk $^{-/}$, illetve a Vt(CARD9) és CARD9-- makrofágok citokinprodukcióját.

Először a $C$. parapsilosis GA1 törzsével stimulált BMDM-ek felülúszójából határoztunk meg citokineket az R\&D Systems Proteome Profiler Mouse Cytokine Array Panel segítségével. Mind a Vt(Syk), mind a Vt(CARD9) makrofágok esetén kimutattuk a TNF $\alpha$-t, valamint a KC (CXCL1), a MIP-1 $\alpha$ (CCL3) és a MIP-2 (CXCL2) kemokineket (11.a,b ábra). $\mathrm{A} \mathrm{Syk}^{-/-}$sejtek TNFa termelése kisebb volt, mint a Vt(Syk) BMDM-eké (11.a ábra). A $\mathrm{CARD}^{-/-}$sejtek esetén nem detektáltuk ezt a citokint (11.b ábra). Míg a Syk ${ }^{-/-}$makrofágokban a kemokinek produkciója a $\mathrm{Vt}(\mathrm{Syk})$ sejtekéhez hasonló volt (11.a ábra), addig a CARD9sejtek felülúszóiban nem (KC, MIP-1 $\alpha$ ) vagy csak kis mennyiségben (MIP-2) azonosítottuk ezeket (11.b ábra).

Eredményeinket ELISA módszerrel, valamint több gombatörzs bevonásával validálni kívántuk. Ezért a C. parapsilosis GA1, CLIB214 és CDC317 törzseivel, referenciaként pedig a C. albicans SC5314 törzsével fertőztük a különböző genotípusú BMDM-eket 24 óra koinkubációs idővel, majd a felülúszókból mértük a TNF $\alpha, \mathrm{KC}, \mathrm{MIP}-1 \alpha$ és MIP-2 citokinek koncentrációját. A 12. ábra a $\mathrm{Syk}^{-/-}$sejtek citokintermelését a $\mathrm{Vt}(\mathrm{Syk})$ makrofágok termelésének százalékában, míg a CARD9-- sejtekét a Vt(CARD9) BMDM-ek termelésének százalékában mutatja. Az abszolút koncentrációk átlagértékeit és szórásait a Függelék 2. táblázata tartalmazza. 


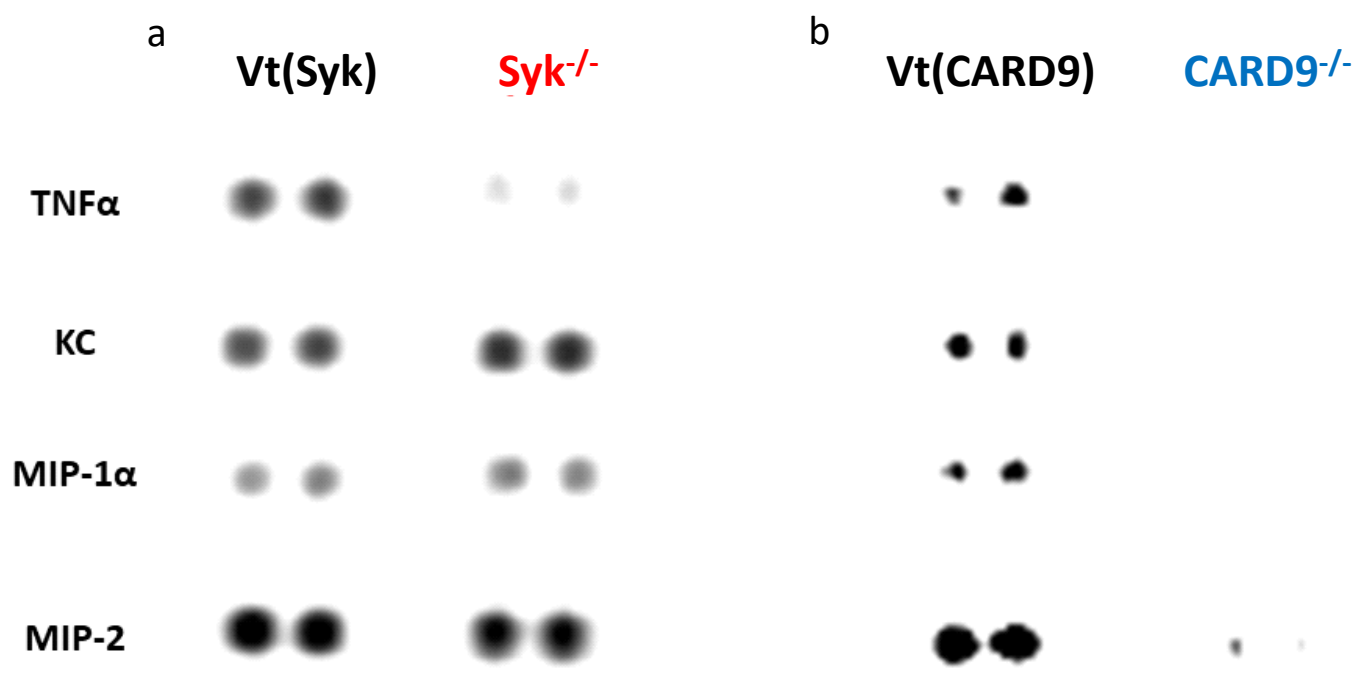

11. ábra. A C. parapsilosisszal fertőzött (GA1 törzs, MOI 5:1, 24 h) (a) Vt(Syk) és Syk ${ }^{-1}$, illetve (b) Vt(CARD9) és CARD9-- BMDM-ek citokinprofiljai. A mérést kezelésenként min. 3-3 független kísérletből származó egybe gyüjtött felülúszókból, az R\&D Systems Proteome Profiler Array Mouse Cytokine Array Panel A kittel hajtottuk végre. A foltok mérete és intenzitása a citokinek mennyiségével arányosak.

A gombákkal történő stimuláció hatására a kezeletlen kontroll sejtek értékeinél magasabb citokinkoncentrációkat regisztráltunk a Vt genotípusok esetén (Függelék 2. táblázat). A C. parapsilosisszal vagy C. albicansszal koinkubált $\mathrm{Syk}^{-/-}$és a CARD9-/makrofágok TNF $\alpha$ termelése legalább 42\%-kal alacsonyabb volt a Vt(Syk) és a Vt(CARD9) sejtekénél (12.a, b ábra). A kemokineket tekintve is legalább 25\%-os csökkenést tapasztaltunk a CARD9-/- BMDM-ek esetén (12.d, f, h ábra). Amíg a C. albicansszal fertőzött Syk ${ }^{-/-}$ makrofágok citokinválasza a kemokinekre nézve $90 \%$-os csökkenést mutatott a Vt sejtekéhez képest, addig a $C$. parapsilosisszal kezelt $\mathrm{Syk}^{-/-}$BMDM-ek kemokin termelése nem volt alacsonyabb Vt kontrollokénál (12.c, e, g ábra).

A kezeléseket ezután PM-eken is elvégeztük. A Candida törzzsekkel történő kezelés most is a kezeletlen kontroll sejtek értékeinél magasabb citokinkoncentrációkat eredményezett a Vt genotípusok esetén (Függelék 2. táblázat). Bármely törzzsel fertőzött Syk $^{-/-}$és CARD9 ${ }^{-/-}$ PM-ek TNF $\alpha$ termelése legalább 67\%-kal alacsonyabb volt a Vt(Syk) és a Vt(CARD9) sejtekénél (13.a, b ábra). A C. parapsilosis fertőzések többségében a CARD9 ${ }^{-/-}$sejtek kemokin termelésének $40-80 \%$-os csökkenését mutattuk ki (13.d, f, h ábra). Bár a C. albicansszal fertőzött CARD9-/- PM-ek citokin termelésének átlaga mindegyik citokinre nézve legalább 34\%-al alacsonyabb volt, mint a Vt(CARD9) sejteké (13.d, f, h ábra), ez az eltérés a MIP-1 $\alpha$ és a MIP-2 esetében nem volt szignifikáns, csak tendenciaszerü (13.f, h ábra). A Syk ${ }^{-/-} \mathrm{PM}$-ek 

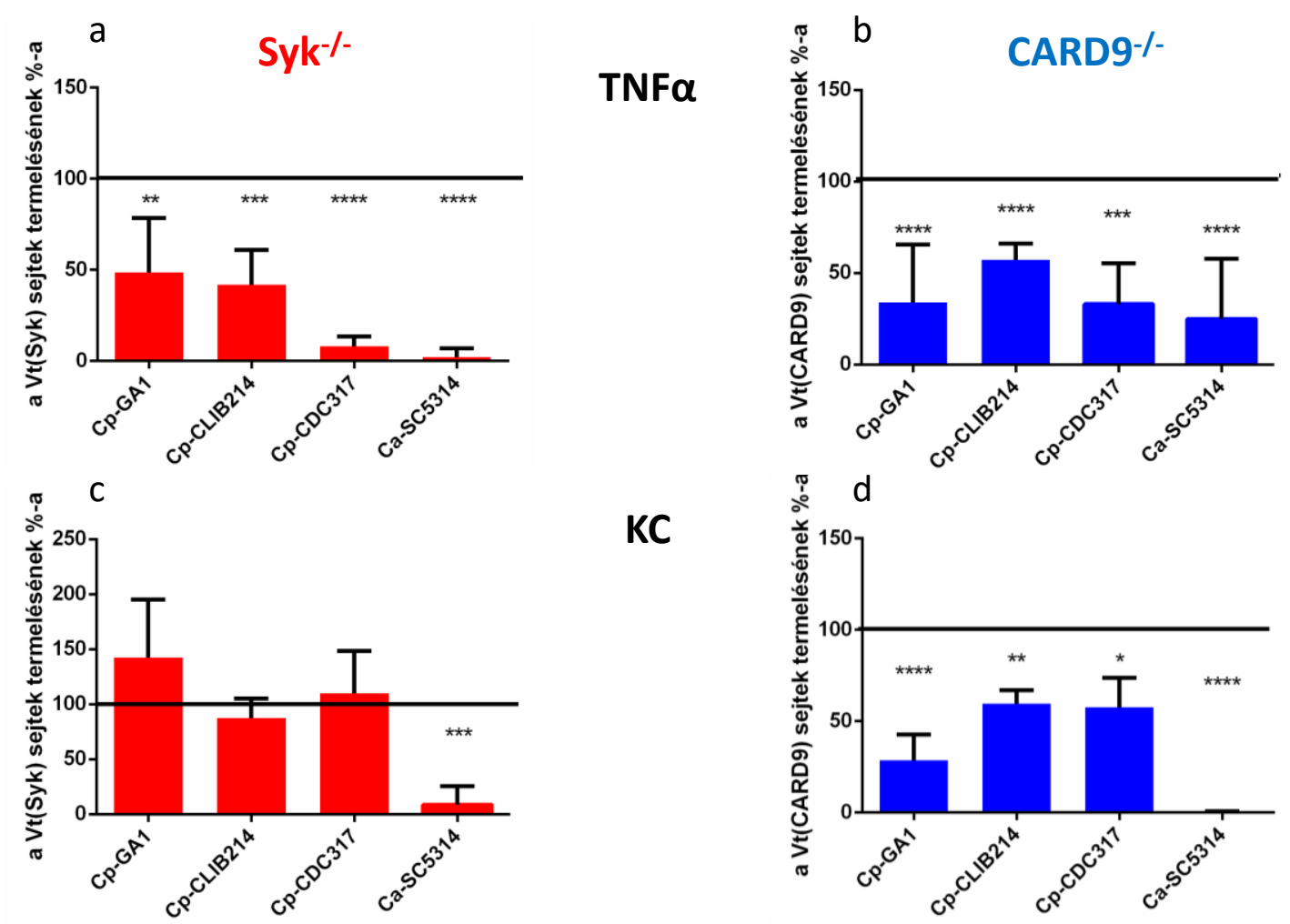

KC
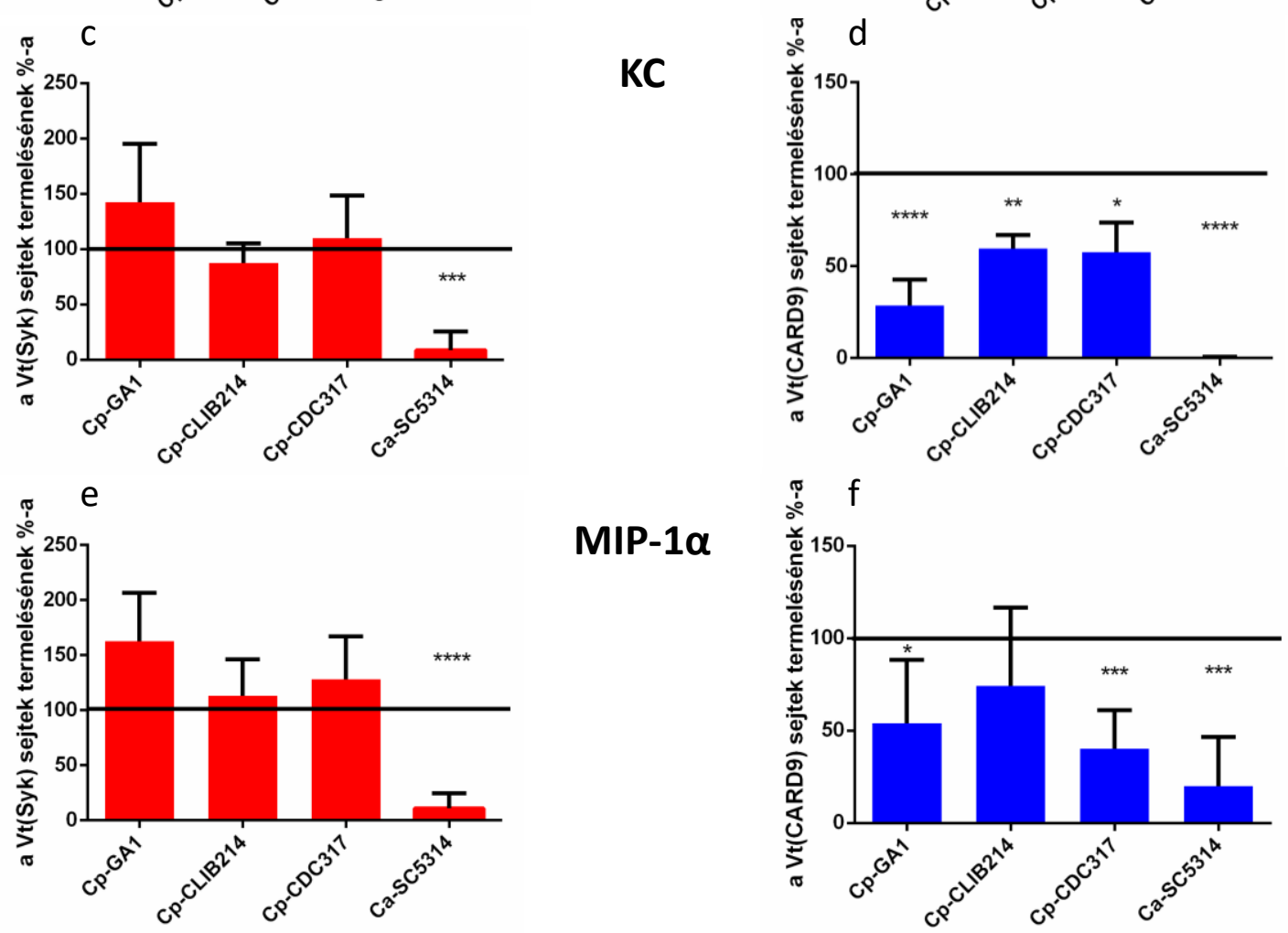

MIP-1 $\alpha$
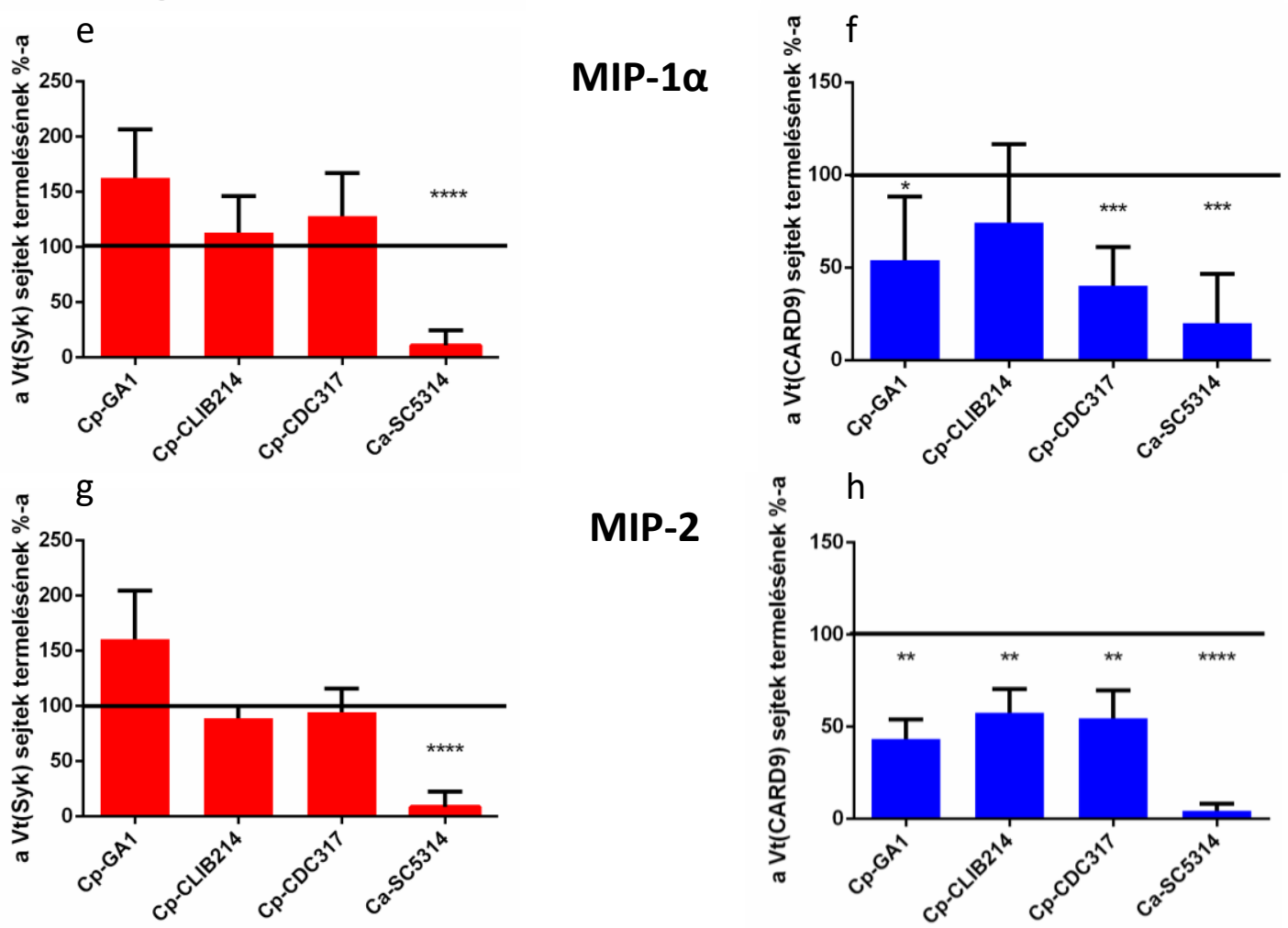

12. ábra. A C. parapsilosisszal (GA1, CLIB214 és CDC317 törzsek, MOI 5:1, 24 h) illetve $C$. albicansszal (SC5314 törzs, MOI 1:25, 24 h) fertőzött (a, c, e, g) Syk ${ }^{-/-}$és (b, d, f, h) CARD9-- BMDMek felülúszóiból mért citokinkoncentrációk a Vt(Syk) és a Vt(CARD9) sejtek felülúszóiból meghatározott koncentrációk százalékában (átlag \pm standard deviáció). A méréseket ELISA módszerrel végeztük. Cp-: C. parapsilosis; Ca-: C. albicans. $\mathrm{n} \geq 3$. *: $\mathrm{p}<0,05 ; * *: \mathrm{p}<0,01 ; * * *: \mathrm{p}<0,001 ; * * * *$ : p $<0,0001$ (páros t-próba). 

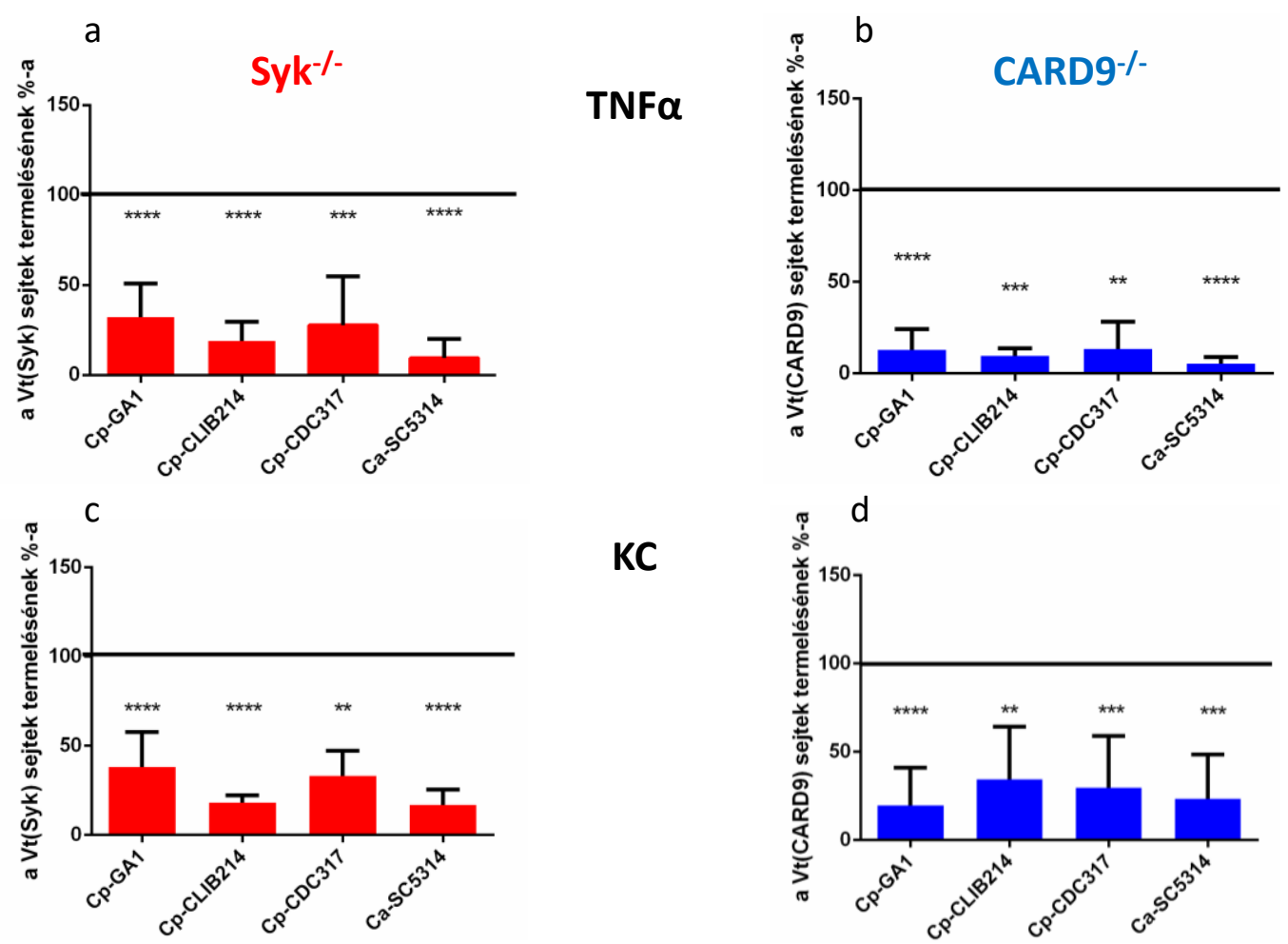

KC
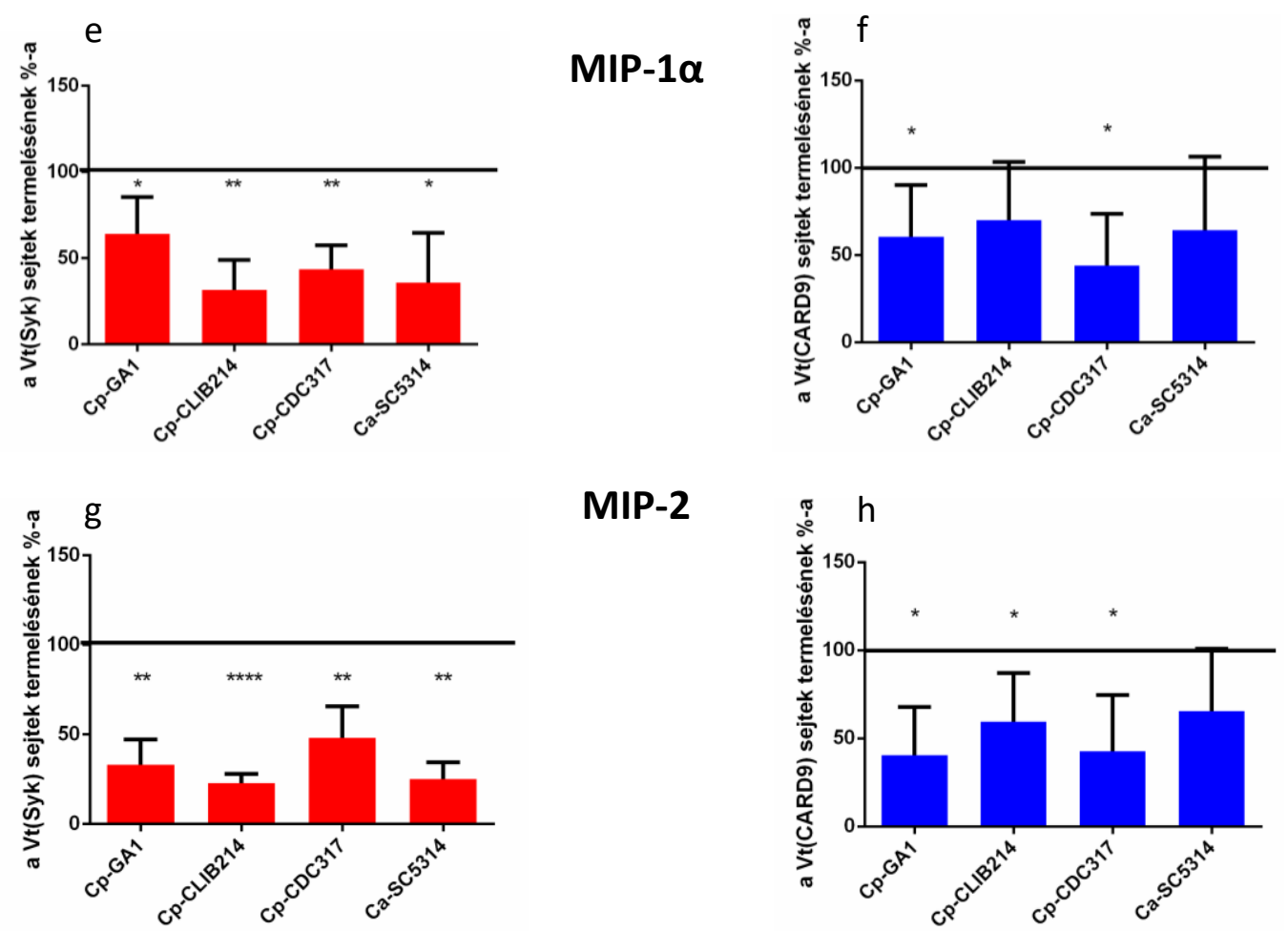

13. ábra. A $C$. parapsilosisszal (GA1, CLIB214 és CDC317 törzsek, MOI 5:1, 24 h) illetve $C$. albicansszal (SC5314 törzs, MOI 1:25, 24 h) fertőzött (a, c, e, g) Syk ${ }^{-/-}$és (b, d, f, h) CARD9-- PM-ek felülúszóiból mért citokinkoncentrációk a Vt(Syk) és a Vt(CARD9) sejtek felülúszóiból meghatározott koncentrációk százalékában (átlag \pm standard deviáció). A méréseket ELISA módszerrel végeztük. Cp: C. parapsilosis; Ca-: C. albicans. $\mathrm{n} \geq 3$. *: $\mathrm{p}<0,05 ; * *: \mathrm{p}<0,01 ; * * *: \mathrm{p}<0,001 ; * * * *: \mathrm{p}<0,0001$ (páros tpróba). 
- a BMDM-ek esetén megfigyeltekkel szemben - a Vt(Syk) sejtekhez viszonyítva minimum 36\%-kal alacsonyabb KC, MIP-1 $\alpha$ és MIP-2 termeléssel voltak jellemezhetők nemcsak a $C$. albicansszal, hanem a $C$. parapsilosisszal stimulált makrofágok esetén is (13.c, e, g ábra).

Eredményeink alapján megállapítottuk, hogy az egér makrofágok $C$. parapsilosis fertőzésre adott citokinválasza a Syk és a CARD9 szabályozása alatt áll. Korábbi vizsgálatunk is utalt erre, mivel a Syk inhibitorral kezelt makrofágszerü THP-1 sejtek IL-1 $\beta$ produkciója alacsonyabb volt a kontroll sejtekétől (Tóth és mtsai. 2017). Azonban az inhibitorok felhasználásával végzett kísérletek eredményei a gátlás mértékének bizonytalansága, illetve az off-target hatások következtében kevésbé megbízhatóak, mint a génkiütéses módszerekkel nyert adatok.

Megerősítettük továbbá ezen jelátviteli út szerepét a $C$. albicans által kiváltott citokin termelésben. Deng és mtsai. (2015) ugyanis $C$. albicans fertőzés során ugyancsak a TNFa, KC, és MIP-2 termelés rendellenességét írták le SHP-2 ${ }^{-/-}$, hibás Syk-aktivációval jellemzett dendritikus sejtekben. A $\mathrm{Syk}^{-/-}$dendritikus sejtek C. albicansszal szemben mutatott alacsony IL-23p19 termelése pedig közvetve a $C$. albicansszal fertőzött egerek túlélésének csökkenését okozta (Whitney és mtsai. 2014).

A TNF $\alpha$ a $C$. albicansszal szembeni in vivo rezisztenciában hangsúlyos, mivel a TNF $\alpha$ receptorára nézve hiányos egerek a Vt állatoknál kevésbé voltak képesek eliminálni a gombát és a fertőzés utáni csökkent túlélés jellemezte őket (Steinshamn és mtsai. 1996). A CARD9 egyik funkcióvesztéssel járó polimorfizmusával rendelkező páciens véréből izolált, majd $C$. albicansszal kezelt sejtek is az egészséges donorokéhoz képest alacsony TNF $\alpha$ szintézist mutattak (Drummond és mtsai. 2015). Whibley és mtsai. (2015) kísérletes $C$. tropicalis fertőzés kapcsán mutatták ki egyes immunsejtek (pl. monociták) és szövetek (pl. veseszövet) CARD9függő TNF $\alpha$ termelését. A CARD9 hiányában az elégtelen TNF $\alpha$ produkció miatt, illetve TNF $\alpha$ gátlót alkalmazva a C. tropicalisszal megfertőzött egerek túlélési ideje rövidebb volt, mint a Vt, vagy gátlószer kezelésben nem részesülő állatoké. A C. parapsilosis képes volt mind humán sejtkultúrákban (Tóth és mtsai. 2013), mind egerek különböző szerveiben (Treviño-Rangel és mtsai. 2015) TNF $\alpha$ szintézist indukálni, azonban ennek a védekezésben betöltött szerepét csak valószínüsítették.

A kemokinek is különösen hatásosak lehetnek a gombák elleni védelemben. A KC és MIP-2 a neutrofilek (De Filippo és mtsai. 2008), a MIP-1 $\alpha$ többek között a makrofágok (Ono és mtsai. 2003) toborzásában játszik szerepet. Ezen citokinekből egy CARD9 polimorfizmust hordozó ember vérsejtjei $C$. albicans fertőzés hatására a Vt CARD9-et expresszáló sejtekhez képest kevesebbet állítottak elő. A CARD9-- egerek agyában pedig a neutrofilekre ható 
kemokinek termelődésének sérülése miatt ezen granulociták C. albicansszal fertőzött agyba történő migrációja alacsony mértékü volt, ami a gomba elszaporodásához vezetett (Drummond és mtsai. 2015). Bár egér makrofágokban kimutatták a MIP-1 $\alpha$ és a MIP-2 mRNS-ének $C$. parapsilosis által indukált transzkripcióját (Németh és mtsai. 2014), a kemokinek hozzájárulása a C. parapsilosisszal szembeni in vivo védekezéshez kevéssé ismert.

Figyelemre méltó, hogy a C. parapsilosis fertőzést követő kemokin expresszió csak a PM-ekben bizonyult Syk-függőnek, a BMDM-ekben nem (12.c, e, g és 13.c, e, g ábra). Ennek egy lehetséges oka a két makrofágtípus eltérő fenotípusa (Zajd és mtsai. 2020). A BMDM-ek például osztódási potenciállal rendelkeznek, a PM-ek nem. Továbbá a PM-ek MHCII expressziója meghaladja a BMDM-ekét, azonban a CD80 kostimulátor esetén a helyzet fordított. A két sejttípus citokintermelése sem teljesen átfedő (Wang és mtsai. 2013, Zhao és mtsai. 2017). Azonos stimulussal kezelt PM-ek és BMDM-ek ellentétes irányú kemokin válaszát is leírták korábban: míg az oxidált alacsony sűrüségű liopoproteinnel inkubált BMDMek MCP-1 kemokin termelése a kezelés hatására lecsökkent, addig a PM-eké megemelkedett (Bisgaard és mtsai. 2016).

Bemutattuk, hogy vizsgálatunkban a C. parapsilosisszal fertőzött BMDM-ek kemokintermelése CARD9-függő, de Syk-független volt (12.c, d, e, f, g, h ábra). Ez arra utalhat, hogy a CARD9 ebben a sejttípusban nem kizárólag a Syk irányából szabályozott. Bi és mtsai. (2010) hasonló jelenséget írtak le. Megfigyelték, hogy a C. albicansszal kezelt BMDMekben az NF-kB aktivációját a CARD9 és a Syk egymástól külön úton és mechanizmussal segítették elő. Az egyik pozitív szabályozó mechanizmus (a NEMO ubikvitinációja) például csak CARD9-függő, de Syk-független volt. A CARD9 által közvetített szignalizációval kapcsolatban több kérdés jelenleg tisztázatlan (pl. részvétele a TLR-ek, vagy NOD2 által iniciált jelátvitelben) (Ruland 2008, Wagener és mtsai. 2014). Így a CARD9-dependens, Sykindependes mechanizmusok tisztázása a jövő feladata.

Bemutattuk továbbá, hogy kísérletünkben a BMDM-ek kemokintermelése csak a $C$. parapsilosis fertőzés esetén volt független a Syktől, a $C$. albicans esetén nem (11.c, e, g ábra). Ez arra utalhat, hogy ebben a sejttípusban az ezen citokinek expressziójához vezető Syk-függő és független szignalizációjú PRR-ek eltérő mértékben vesznek részt a két faj felismerésében.

\section{VI.3. A C . parapsilosis és a $C$. albicans egér makrofágok általi fagocitózisa a Syk szabályozása alatt áll}

Több Syk/CARD9-en keresztül szignalizáló PRR szerepet játszik egyes falósejtek Candida sejteket bekebelező képességében (Gantner és mtsai. 2005, Ifrim és mtsai. 2013, 
Gazendam és mtsai. 2014, Wang és mtsai. 2016). A C. glabrata makrofágok általi fagocitózisa például Dectin-2- (Ifrim és mtsai. 2013), a C. tropicalisé pedig Dectin-3-függő volt (Wang és mtsai. 2016). Mivel jelenlegi ismereteink alapján a Dectin-2 és Dectin-3 nem szignalizálnak a Syk megkerülésével (Salazar és Brown 2018), továbbá mivel a C. parapsilosis és C. albicans sejtfala is tartalmaz Dectin-2/Dectin-3 ligandumként jellemzett mannánt (Shibata és mtsai. 1995, Papp és mtsai. 2018), feltételeztük, hogy a makrofágok C. parapsilosist és C. albicanst bekebelező aktivitására is hatással lehet a Syk/CARD9 jelátvitel.

Ennek tisztázására a $C$. parapsilosis Alexa Fluor $^{\circledR} 488$ szukcinimidil észterrel jelölt GA1 és CDC317, illetve a GFP-CLIB214 törzseivel, valamint a C. albicans Alexa Fluor ${ }^{\circledR} 488$ cal jelölt SC5314 törzsével fertőztünk Vt(Syk), Syk ${ }^{-/-}$, Vt(CARD9) és CARD9-/- BMDM-eket. A kísérlet során képalkotó áramlási citométerrel kvantifikáltuk a fagocitáló makrofágok százalékos arányát és az egy BMDM által fagocitált gombasejtek átlagos számát a fagocitáló sejtpopuláción belül. Egy korai (15 perc) és egy késői (120 perc) koinkubációs időt alkalmaztunk, az utóbbi a C. albicans esetén a hifázást megelőzendő 30 perc volt. A fagocitáló $\mathrm{Vt}(\mathrm{Syk})$ sejtpopuláció aránya minden esetben nagyobb volt a fagocitáló Syk $^{-/-}$populáció arányánál. A korai időpontban a $C$. parapsilosis sejteket fagocitáló sejtpopuláció összesített átlagos aránya a $\mathrm{Vt}(\mathrm{Syk})$ makrofágok esetén 19,45\%, míg a Syk ${ }^{-/-}$makrofágok esetén 5,92\% volt. Ebben az időpontban a $C$. albicans sejteket fagocitáló populáció aránya a $\mathrm{Vt}(\mathrm{Syk})$ sejtek esetén 29,8\%, míg a $\mathrm{Syk}^{-/-}$sejtek esetén 20,23\% volt (14.a ábra). A késői időpontban a $C$. parapsilosis sejteket fagocitáló sejtpopuláció összesített átlagos aránya a Vt(Syk) makrofágok esetén $68,19 \%$, míg a $\mathrm{Syk}^{-/-}$makrofágok esetén 38,61\% volt. Ezen kísérleti időpontban a $C$. albicans sejteket fagocitáló populáció aránya a Vt(Syk) sejtek esetén 62,26\%, míg a Syk ${ }^{-/-}$ sejtek esetén 54,06\% volt (14.a ábra). Az egy makrofág által fagocitált gombasejtek számában a korai időpontban nem találtunk szignifikáns különbséget a Vt(Syk) és Syk $^{-/-}$makrofágok között. A késői időpontokban viszont a $C$. parapsilosis GA1-et és CDC317-et fagocitáló $\mathrm{Vt}(\mathrm{Syk})$ BMDM-ek átlagosan több gombasejtet vettek fel, mint a $\mathrm{Syk}^{-/-}$makrofágok [Vt(Syk):

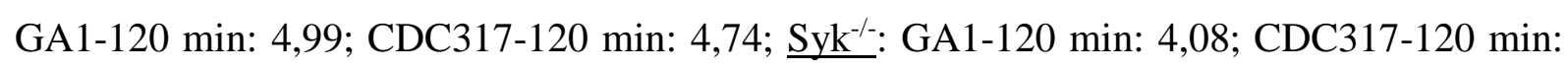
3,62; 14.c ábra]. Ezen törzsek esetén a fagocitáló populáción belül a különböző számú gombasejtet tartalmazó makrofágok gyakoriságeloszlása azt mutatta, hogy míg az 1-2 gombasejtet tartalmazó Syk ${ }^{-/-}$sejtek gyakorisága felülmúlta a Vt(Syk) makrofágokét, addig az 5 vagy annál több élesztőt tartalmazó populációkban ez fordítva volt (14.e ábra). A Vt(CARD9) és CARD9-/- BMDM-ek C. parapsilosist vagy $C$. albicanst fagocitáló képessége között nem tapasztaltunk különbséget (14.b,d, f ábra). 

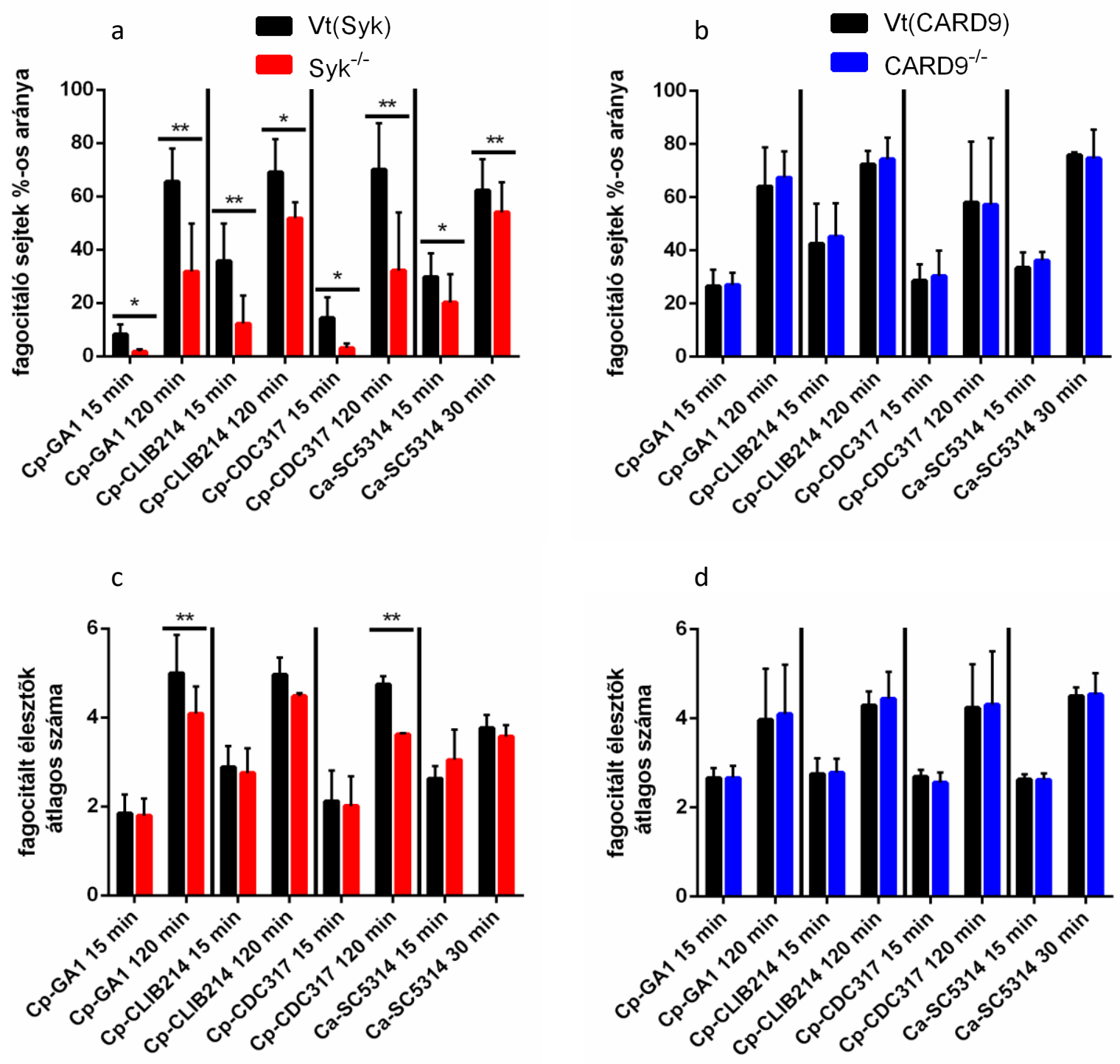

e
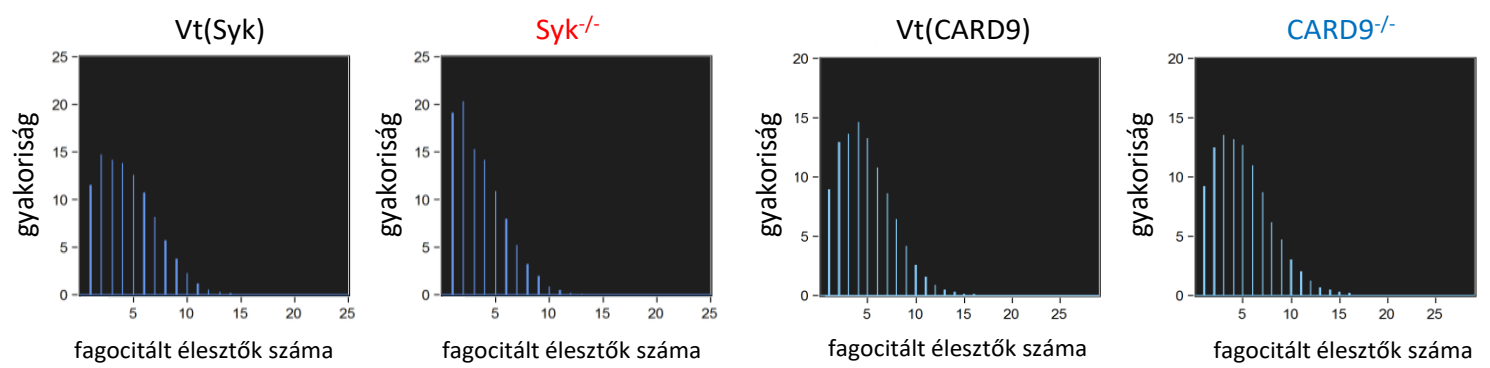

14. ábra. A Syk és CARD9 hatása a BMDM-ek C. parapsilosist és $C$. albicanst fagocitáló képességére. A makrofágokat fluoreszcens Candida sejtekkel koinkubáltuk (15, továbbá 30 vagy 120 perc, MOI 5:1). A fagocitózis mértékét képalkotó áramlási citométerrel határoztuk meg. (a, b) A fagocitáló BMDM-ek az összes lemért BMDM-ek \%-ában és (c, d) a fagocitált gombák egy BMDM-en belüli átlagos mennyisége a fagocitáló popupláción belül (átlag \pm standard deviáció). (e,f) Reprezentatív Spot Count diagramok C. parapsilosisszal (CDC317) fertőzött Vt(Syk) és Syk ${ }^{-{ }^{-}}$, illetve a GA1 törzzsel fertőzött Vt(CARD9) és CARD9-/- BMDM-ekről. Cp-: C. parapsilosis; Ca-: C. albicans, min: perc. $\mathrm{n} \geq 3$. *: $\mathrm{p}<0,05 ; * *: \mathrm{p}<0,01$ (páros t-próba). 
A következőkben eredményeinket PM-ekkel végzett vizsgálatokkal is meg kívántuk erősíteni. Ebben az esetben a C. parapsilosis fertőzések hosszabb inkubációs ideje 60 perc volt. Mivel az előző vizsgálatban a $C$. parapsilosis törzsekre adott válaszok részben hasonlók voltak, ez úttal csak a GA1 törzset alkalmaztuk. A Vt(Syk) makrofágokhoz képest kevesebb fagocitáló $\mathrm{Syk}^{-/-}$sejtet regisztráltunk a $C$. parapsilosis fertőzés mindkét időpontjában, illetve a $C$. albicans fertőzés korai időpontjában [Vt(Syk): GA1-15 min: 19,36\%; GA1-60 min: 78,5\%; SC5314-15 min: 53,7\%; Syk $^{-/-}$: GA1-15 min: 7,92\%; GA1-60 min: 48,27\%; SC5314-15 min: 28,83\%; 15.a ábra]. A C. albicansszal történő kezelés esetén a 30 perces időpontban ez a csökkenés csak trend szinten jelent meg (15.a ábra). A C. parapsilosisszal fertőzött Vt(Syk) makrofágokban a késői időpontban több internalizált gombasejtet mutattunk ki a fagocitáló populáción belül,

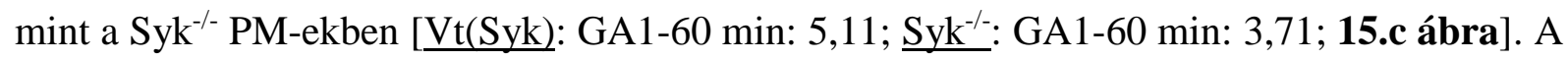
C. albicansszal fertőzött Syk $^{-/-}$sejtek nem kebeleztek be szignifikánsan kevesebb gombát, mint Vt(Syk) társaik (15.c ábra). A PM-ek nem tértek el egymástól CARD9-függő módon a $C$. parapsilosist vagy C. albicanst fagocitáló aktivitásukban (15.b, d ábra).

Adatainkból azt a következtetést vontuk le, hogy a Syk a CARD9-töl független mechanizmuson keresztül szerepet játszik az egér makrofágok $C$. parapsilosisszal és $C$. albicansszal szemben mutatott fagocitikus aktivitásában. Ez összhangban van a C. glabrata PM-ek általi Dectin-2-függő (Ifrim és mtsai. 2013) és a C. tropicalis BMDM-ek általi Dectin3-függő (Wang és mtsai. 2016) fagocitózisával, illetve azzal, hogy egér dendritikus sejtekben a zimozán fagocitózisa Syk-függő (Rogers és mtsai. 2005, Gross és mtsai. 2006) volt. A $C$. glabrata PM-ek általi felvétele korai kísérleti időpontban szintén Syk-függő volt (Dagher és mtsai. 2018). A Syk inhibitorral kezelt egér fibroblasztok, valamint SHP-2 foszfatáz hiányos egér BMDM-ek is csökkent mértékben internalizálták a zimozánt (Herre és mtsai. 2004, Deng és mtsai. 2015). Azonban a zimozánpartikulumok BMDM-ek általi internalizációját két vizsgálatban is Syk-függetlennek tapasztalták (Herre és mtsai. 2004, Underhill és mtsai. 2005). Mivel a zimozán érzékelése TLR-ek által is végbemehet (Sato és mtsai. 2003), és a Candida sejtfalban található szerkezetileg heterogénebb PAMP-okat többféle Syk-függő receptor is kötheti, ezért a $C$. parapsilosis és a $C$. albicans Syk-függő fagocitózisa nem mond ellent a zimozán Syk-független bekebelezésének. A zimozán BMDM-ekben leírt SHP-2-függő (Deng és mtsai. 2015), de Syk-független (Herre és mtsai. 2004, Underhill és mtsai. 2005) fagocitózisának ellentmondása azonban még feloldatlan. Megjegyzendő továbbá, hogy egy vizsgálatban a Syk blokkolóval kezelt BMDM-ek normális mértékben vettek fel hővel elölt „élesztő partikulumokat” (Majeed és mtsai. 2001). A szerzők és saját munkánk eredményeinek 

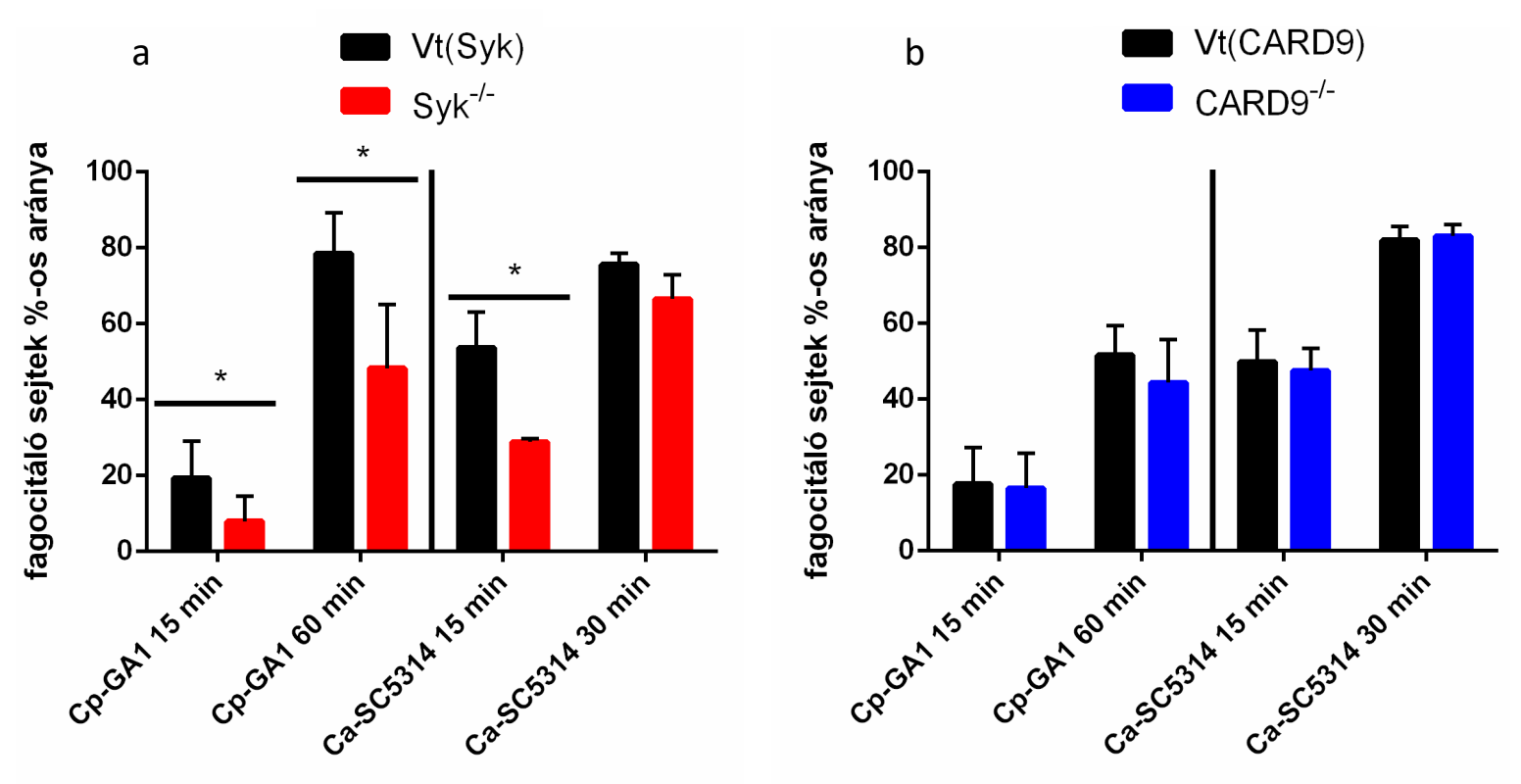

C
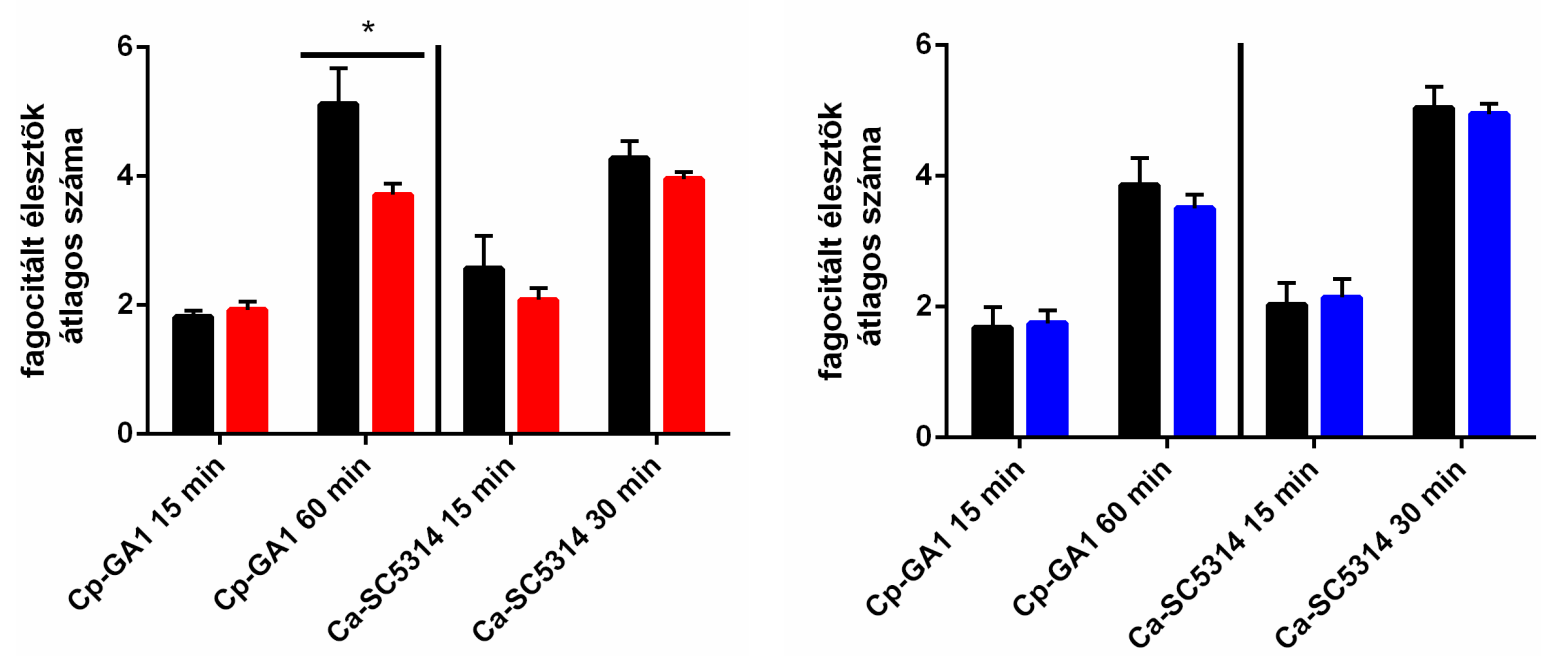

15. ábra. A Syk és CARD9 hatása a PM-ek $C$. parapsilosist és $C$. albicanst fagocitáló képességére. A makrofágokat fluoreszcens Candida sejtekkel koinkubáltuk (15, továbbá 30 vagy 60 perc, MOI 5:1). A fagocitózis mértékét képalkotó áramlási citométerrel határoztuk meg. (a, b) A fagocitáló PM-ek az összes lemért PM-ek \%-ában és (c, d) a fagocitált gombák egy PM-en belüli átlagos mennyisége a fagocitáló popupláción belül (átlag \pm standard deviáció). Cp-: C. parapsilosis; Ca-: C. albicans, min: perc. $\mathrm{n} \geq 3$. *: $\mathrm{p}<0,05$ (páros t-próba).

eltérését talán metodikai különbségek indokolják. A tanulmánnyal ellentétben mi meghatározott fajokkal, élő gombasejtekkel és kémiai gátlás helyett $S \mathrm{k}^{-/-}$sejtekkel dolgoztunk.

Adataink illeszkednek azokhoz az eredményekhez, melyek szerint a CARD9 sem makrofágokban, sem dendritikus sejtekben nincs hatással a zimozán internalizációjára (Gross és mtsai. 2006, Goodridge és mtsai. 2009). 


\section{VI.4. A C. parapsilosis tartalmú fagoszómák savasodása függ a Syktől, de a CARD9-től}

nem

Majeed és mtsai. (2001) vizsgálatában a Syk gátlása BMDM-ekben akadályozta a hővel elölt „élesztő partikulum” tartalmú fagoszómák és a lizoszómák fúzióját. Egér makrofágszerü sejtvonalban pedig a Syk blokkolása gátolta a $\beta$-glükán partikulum tartalmú fagoszómák érését, illetve a C. albicans tartalmú fagoszómák savasodását (Mansour és mtsai. 2013).

Ezek ismeretében feltételeztük, hogy a Syk/CARD9 jelátvitel a C. parapsilosis tartalmú fagoszómák savasodására is hatással lehet. Ezért a különböző genotípusú BMDM-eket Alexa Fluor® 488 szukcinimidil észterrel, valamint a savas kémhatású fagolizoszómákban fluoreszkáló pHrodo ${ }^{\mathrm{TM}}$ Reddel szimultán festett $C$. parapsilosis GA1 és CDC317 törzsekkel vagy pHrodo $^{\mathrm{TM}}$ Reddel jelölt GFP-CLIB214 törzzsel fertőztünk, illetve referenciaként hasonlóan jártunk el a $C$. albicans törzzsel. Az inkubációs idő lejártával meghatároztuk a pHrodo $^{\text {TM }}$ Red $^{+}$és az Alexa Fluor ${ }^{\circledR} 488^{+}$sejtpopulációkat, ezek alapján pedig a fagoszómák savasodásának hatékonyságát.

Mind a $C$. parapsilosis törzsekkel, mind a $C$. albicansszal stimulált Syk $^{-/-}$BMDM-ekben kisebb hatékonysággal következett be a fagoszómák savasodása, mint a Vt(Syk) sejtekben [(Vt(Syk): GA1: 86,46\%; CLIB214: 59,38\%; CDC317: 72,55\%; SC5314: 38,67\%; Syk $^{-1-}:$ GA1: 58,7\%; CLIB214: 28,93\%; CDC317: 42,08\%; SC5314: 15,16\%; 16.a ábra). Ilyen eltérést a

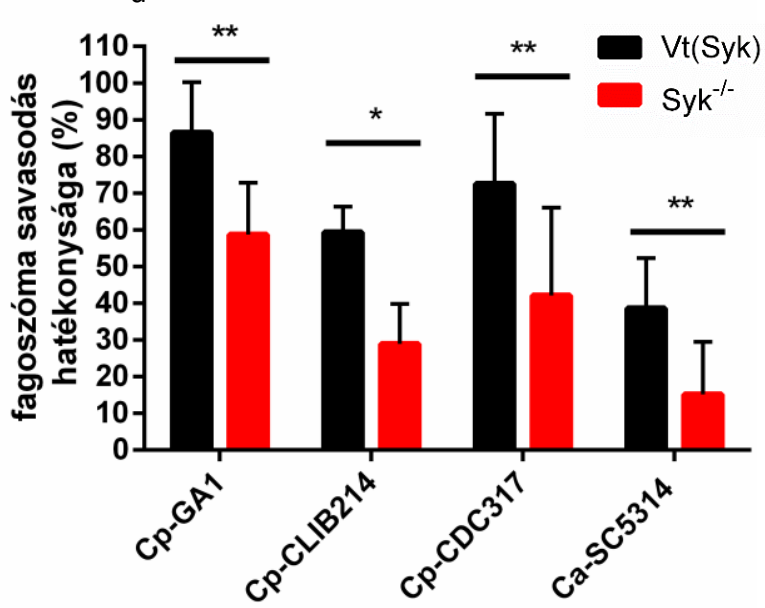

b

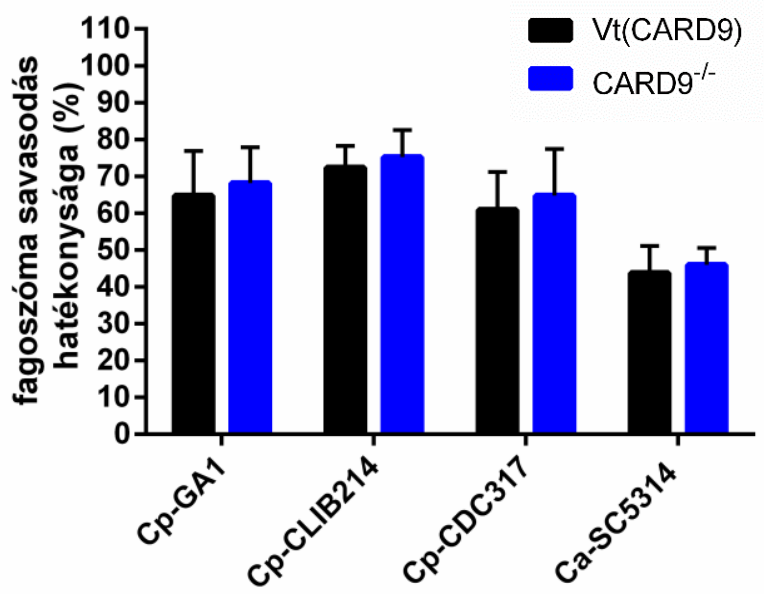

16. ábra. (a) A Syk és (b) a CARD9 hatása a $C$. parapsilosis és a $C$. albicans bekebelezését követő fagoszóma savasodásra BMDM-ekben. Az élesztôsejteket Alexa Fluor® 488 szukcinimidil észterrel és pHrodo $^{\mathrm{TM}}$ Reddel, a GFP-CLIB214 sejtjeit pHrodo $^{\mathrm{TM}}$ Reddel festettük, majd a jelölt gombákkal fertőztük a makrofágokat (15 perc, MOI 5:1). A fagoszómák savasodásának hatékonyságát képalkotó áramlási citométerrel határoztuk meg (átlag \pm standard deviáció). Cp-: C. parapsilosis; Ca-: C. albicans. $\mathrm{n} \geq 3$. *: $\mathrm{p}<0,05 ; * *: \mathrm{p}<0,01$ (páros t-próba). 
Vt(CARD9) és CARD99-- BMDM-ek között nem észleltünk (16.b ábra).

Megfigyeléseinket ezt követően PM-ekkel végzett vizsgálatokkal is meg kívántuk erősíteni. Mivel a $\mathrm{Syk}^{-/}$BMDM-ekben megfigyelt csökkent savasodást az összes $C$. parapsilosis törzs esetén kimutattuk, csak a GA1 törzzsel dolgoztunk tovább. A Syk ${ }^{-/-} \mathrm{PM}-$ ekben a fagoszómák savasodásának hatékonysága a $C$. parapsilosis fertőzést követően kisebb volt, mint a Vt(Syk) makrofágokban [( $\underline{\mathrm{Vt}(\mathrm{Syk})}: \mathrm{GA} 1: 51,23 \%$; $\underline{\mathrm{Syk}^{-/-}}: \mathrm{GA} 1: 34,03 \%$; 17.a ábra]. A Syk ${ }^{-/}$PM-ekben a C. albicans fagocitózisát követően a savasodás hatékonysága közel szignifikáns $(\mathrm{p}=0,084)$ trend szerint szintén alacsonyabb volt, mint a Vt(Syk) sejteké [( $\underline{\mathrm{Vt}(\mathrm{Syk})}$ : SC5314: 54,44\%; Syk $^{-/}:$SC5314: 31,3\%; 17.a ábra]. A Vt(CARD9) és CARD9-/- PM-ek között nem detektáltunk eltérést (17.b ábra).

A bemutatott eredményekből arra következtettünk, hogy egér makrofágokban a Syk a CARD9-től független módon hozzájárul a $C$. parapsilosis tartalmú fagoszómák érési folyamatához. Hővel elölt C. albicansszal kezelt RAW egér makrofágszerü sejtekben hasonló eredményt kaptak Mansour és mtsai. (2013), amit most élő C. albicans felhasználásával primer makrofágokban megerősítettünk. Adataink egybe esnek az „élesztő partikulumokkal” stimulált Syk gátlószerrel kezelt BMDM-ek (Majeed és mtsai. 2001), továbbá a $\beta$-glükán partikulumokkal stimulált Syk-blokkolt RAW sejtek (Mansour és mtsai. 2013) fagoszómáinak sérült savasodásával. Megjegyzendő, hogy Drewniak és mtsai. (2013) elektonmikroszkópos felvételeken egy CARD9-deficiens beteg neutrofil granulocitáiban abnormális, duzzadt fagoszómákat figyeltek meg a $C$. albicans fagocitózisát követően, azonban a fagoszómák savasodását nem vizsgálták.

\section{VI.5. A C. parapsilosis BMDM-ek általi eliminációja Syk-függő, de CARD9-független}

Dagher és mtsai. (2018) tanulmányában a Syk gátlásakor a PM-ek csökkent mértékben akadályozták a fagocitált $C$. glabrata sejtek intracelluláris osztódását. A CARD9-- egér eredetü monociták viszont a vad típusúakhoz hasonló normális mértékben voltak képesek elpusztítani a C. tropicalist (Whibley és mtsai. 2015). Bemutatott kísérleteinkben pedig a C. parapsilosis makrofágok általi internalizációja és az ezt követő fagoszóma savasodás Syk-függő, de CARD9-független volt. Így feltételeztük, hogy a makrofágok $C$. parapsilosist elimináló képessége a Syk hiányában sérül, míg a CARD9 hiányában nem károsodik.

Ezért összehasonlítottuk a Vt(Syk), a Syk ${ }^{-/-}$, valamint a Vt(CARD9) és CARD9-/- BMDM-ek C. parapsilosisszal szemben mutatott ölési hatékonyságát. A Syk ${ }^{-/-}$sejtek ölési hatékonysága alacsonyabb volt a Vt(Syk) makrofágokénál [( $\underline{\mathrm{Vt}(\mathrm{Syk})}$ : GA1: 25,04\%; CLIB214: 22,06\%; CDC317: 30,3\%; Syk $^{-1-}$ : GA1: 13,52\%; CLIB214: 13,45\%; CDC317: 21,11\%], ez a csökkenés 


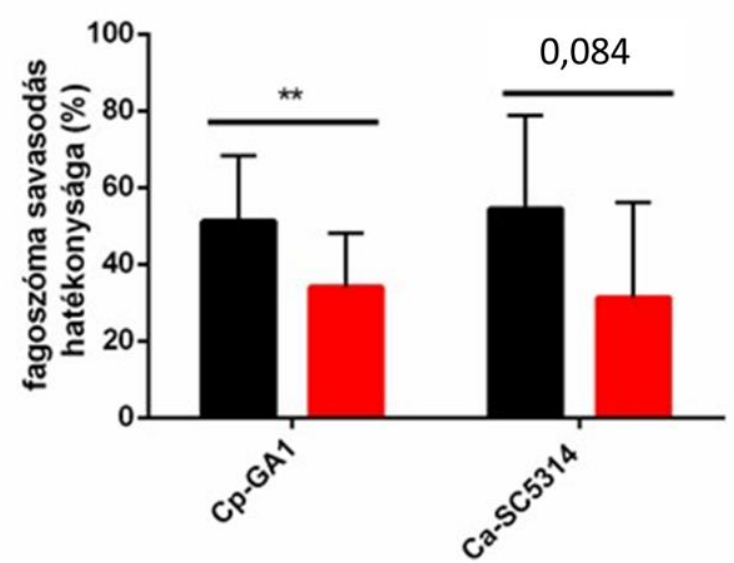

b

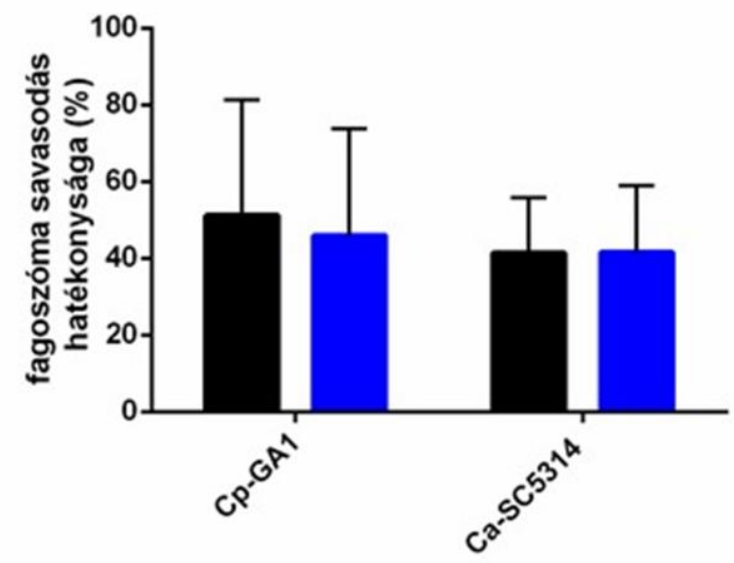

17. ábra. (a) A Syk és (b) a CARD9 hatása a C. parapsilosis és a C. albicans fagocitózisát követő fagoszóma savasodásra PM-ekben. Az élesztőket Alexa Fluor® 488 szukcinimidil észterrel és pHrodo ${ }^{\mathrm{TM}}$ Reddel festettük, majd a jelölt gombákkal fertőztük a makrofágokat (15 perc, MOI 5:1). A fagoszómák savasodásának hatékonyságát képalkotó áramlási citométerrel határoztuk meg (átlag \pm

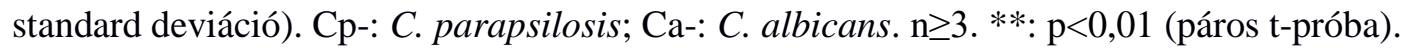

azonban a CDC317-tel fertőzött sejtek esetében csak közel szignifikáns $(p=0,0726)$ trendet jelentett (18.a ábra). A Vt(CARD9) és CARD9-- BMDM-ek ölési képessége nem tért el egymástól (18.b ábra). A GA1 törzset felhasználva a kísérletet elvégeztük PM-ekkel is. Ebben az esetben a Syk $^{-/-}$sejtek ölési hatékonysága nem maradt el szignifikáns módon a Vt(Syk) makrofágokétól (18.c ábra), és a PM-ek ölési képessége a CARD9 jelenlététől függetlenül hasonló mértékű volt (18.d ábra).

Az eredményekből arra következtettünk, hogy BMDM-ekben a Syk a CARD9-től független módon szerepet játszhat a $C$. parapsilosis eliminációjában. A PM-ek esetében ez nem igazolódott. Lehetséges, hogy ebben a sejttípusban az ölési hatékonyságra kisebb hatást gyakorol a Syk, mint a BMDM-ekben, és az általunk alkalmazott módszer nem elég érzékeny ennek kimutatására, valamint az is, hogy a PM-ek ölési mechanizmusa Syk-független. A humán neutrofil granulociták Syk-függő módon eliminálták a C. albicanst (Gazendam és mtsai. 2014). Az egér neutrofil granulociták C. albicanst elpusztító képessége szintén nem függött a CARD9től (Li és mtsai. 2016). A CARD9 hibás génvariációjával rendelkező emberi monociták és neutrofilek viszont kevésbé voltak hatékonyak a $C$. albicans élesztő formájának elpusztításában, mint a Vt sejtek. Ez a defektus azonban nem érintette a hifális forma elleni aktivitást (Drewniak és mtsai. 2013, Drummond és mtsai. 2015). 

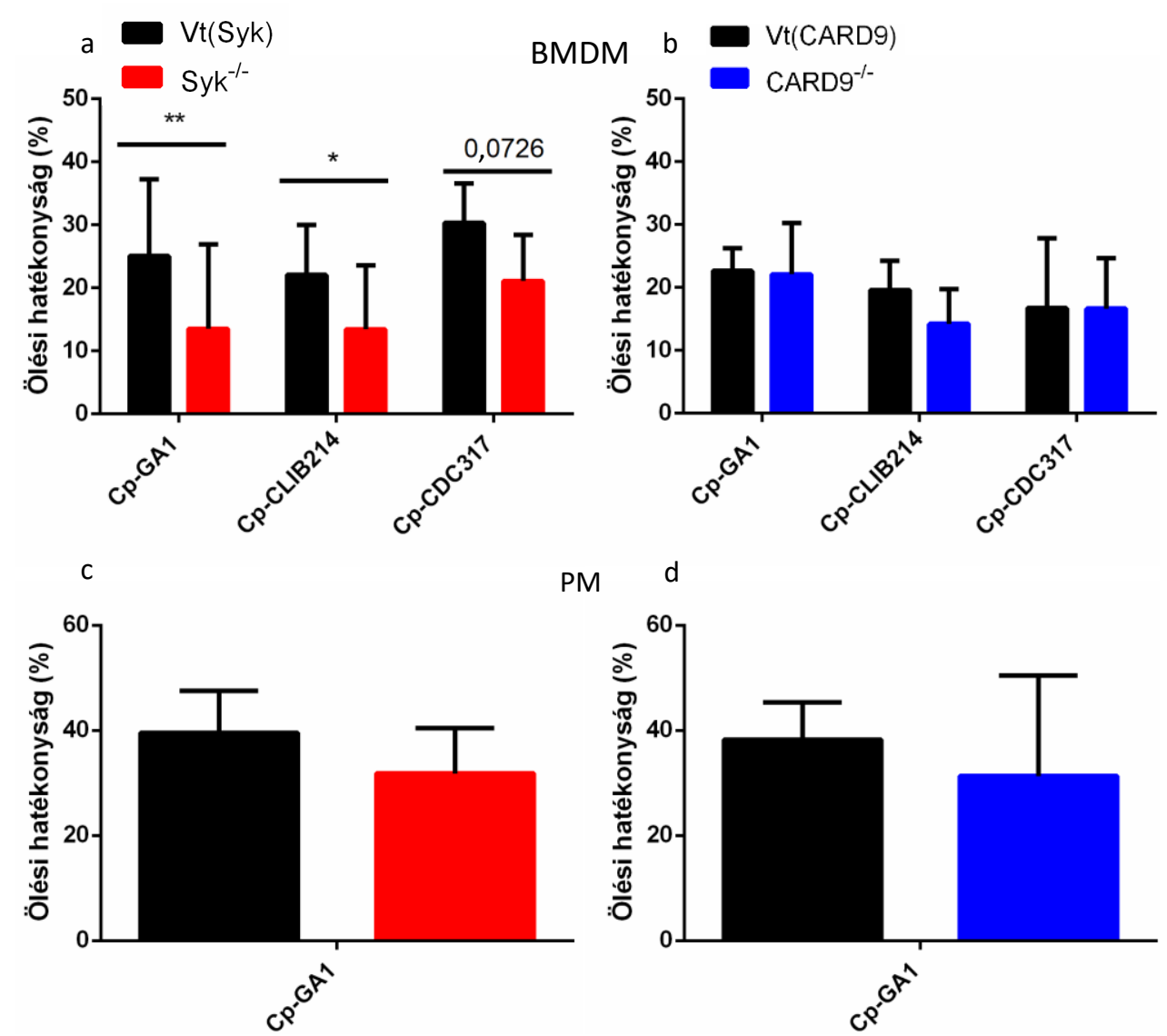

PM d

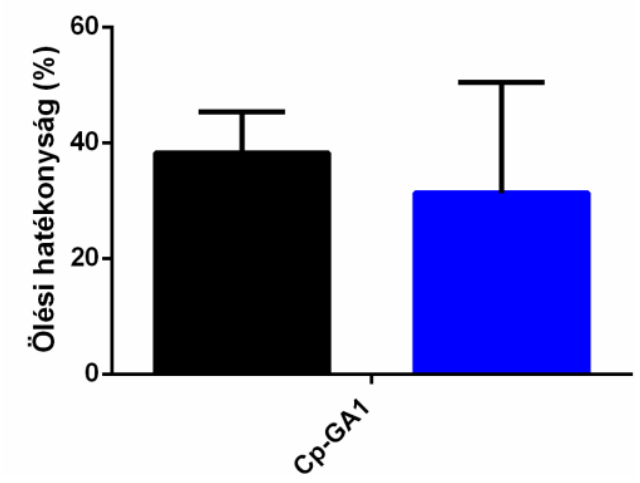

18. ábra. (a, c) A Syk és (b,d) a CARD9 hatása C. parapsilosis egér makrofágok általi eliminációjára. A BMDM-eket (a, b) és PM-eket (c, d) C. parapsilosisszal fertőztük (3h, MOI 5:1), majd meghatároztuk az ölési hatékonyságot (átlag \pm standard deviáció). Cp-: C. parapsilosis; Ca-: C. albicans. $\mathrm{n} \geq 3$. *: $\mathrm{p}<0,05 ; * *: \mathrm{p}<0,01$ (páros t-próba).

\section{VI.6. A Syk/CARD9 jelátvitel hozzájárul a szisztémás $C$. parapsilosis fertőzés során}

\section{kialakuló védekezéshez}

A Syk és a CARD9, valamint a rajtuk keresztül szignalizáló PRR-ek in vivo egér modellben jelentős szerepet játszottak az invazív kandidiázissal szembeni védekezésben, (Chen és mtsai. 2017, Drummond és mtsai. 2015, Gross és mtsai. 2006, Jia és mtsai. 2014, Taylor és mtsai. 2006, Tsoni és mtsai. 2009, Wells és mtsai. 2008, Whibley és mtsai. 2015, Whitney és mtsai. 2014, Zhu és mtsai. 2013). A Syk és a CARD9 jelentősége a C. parapsilosis okozta invazív fertőzés során azonban nem ismert.

Mivel a bemutatott in vitro kísérleteink arra utaltak, hogy a Syk és a CARD9 részt vesznek a $C$. parapsilosis felismerésében, feltételeztük, hogy a $\mathrm{Syk}^{-/-}$és a CARD9-/- kiméra egerek kevésbé képesek kontrollálni a $C$. parapsilosis okozta szisztémás fertőzést, mint a Vt(Syk) és Vt(CARD9) kimérák. Ennek tesztelésére a különböző genotípusú állatokat a $C$. parapsilosis GA1 törzsével, valamint referenciaként a C. albicans SC5314 törzsével 
intravénásan fertőztük. Ezek után a $C$. parapsilosis törzzsel fertőzött állatokban a kezelést követő 2., 5., 7. és 30. napon meghatároztuk a gombakolonizáltság mértékét a vérben (kivéve a 30. napi időpontot), a lépben, a vesékben, a májban és az agyban. A fertőzést követő 2 . napon a $C$. albicans törzzsel kezelt állatok esetén is így jártunk el. A későbbi időpontokig a $C$. albicansszal fertőzött Syk $^{-/-}$és CARD99-/- kiméra állatok nem élnek túl.

Két nappal a fertőzést követően a $C$. parapsilsosisszal fertőzött $\mathrm{Syk}^{-/-}$kiméra egerek lépében 2,2-szer, veséjében 1,7-szer magasabb kolonizáltságot mutattunk ki, mint a Vt(Syk) kimérák ezen szerveiben. A többi vizsgált szövet esetén szignifikáns eltérést nem észleltuink (19.a ábra). A C. albicans fertőzés esetén az összes vizsgált szervben az egy nagyságrendet közelítően vagy azt meghaladóan több CFU-t észleltünk a Syk ${ }^{-/-}$kiméra állatokban, mint a $\mathrm{Vt}$ (Syk) kimérákban (19.b ábra). A Syk ${ }^{-/-}$kimérák veséin makroszkóposan is láthatók voltak a C. albicans kolóniák okozta egyenetlen kinövések (21.a ábra). Ezt a fajt azonban semelyik genotípusú állat vérében nem detektáltuk. A későbbi időpontokban a $C$. parapsilosisszal fertőzött Syk ${ }^{-/}$kimérák véréből és összes vizsgált szervéből több CFU-t határoztunk meg, mint a Vt(Syk) kimérák esetén. Ez 30 nappal a fertőzés után az agyban 2, a májban, és még kifejezettebben a vesében 3 nagyságrendbeli különbséget jelentett (19.a ábra).

Két nappal a fertőzést követően a $C$. parapsilosisszal fertőzött CARD9 ${ }^{-/-}$kiméra egerek lépében 2,7-szer, veséjében pedig 2-szer magasabb gombakolonizáció találtunk, mint a Vt(CARD9) kimérák szerveiben. A vér, a máj és az agy esetén nem azonosítottunk szignifikáns különbséget (20.a ábra). A C. albicansszal fertőzött CARD9-/- kimérák minden vizsgált szervében magasabb volt a gombakolonizációt, mint a Vt(CARD9) kimérák esetén (20.b ábra). Ez az eltérés az agy esetén 20-szoros, a vesék esetén több mint két nagyságrend volt, ami ez utóbbi szerv patológiás megjelenésével járt együtt (21.b ábra). A vérben most sem nem detektáltuk a $C$. albicanst. A későbbi időpontokban a $C$. parapsilosisszal fertőzött CARD9-/kimérák véréből és összes vizsgált szervéből több CFU-t határoztunk meg, mint a Vt(CARD9) kimérák esetén (20.a ábra). A különbség nagysága a 30. napon az agyban és a vesékben elérte a több, mint 2 nagyságrendet (20.a ábra).

Mivel egér modellszervezetben a kísérletes szisztémás Candida fertőzések fő célszervei a vesék (Whitney és mtsai. 2014, Navarathna és mtsai. 2016), a fertőzést követő 2. napon szövettani preparátumokban is összehasonlítottuk a $C$. parapsilosis és a $C$. albicans megjelenését a veseszövetekben. A szervekből készült metszeteket PAS-festésnek vetettük alá, amely szembetűnővé teszi a Candida fajok megjelenési formáit. A C. parapsilosisszal injektált Vt(Syk), Vt(CARD9), Syk ${ }^{-/-}$és CARD9-/- kiméra állatok veséiben nem, vagy csak elvétve észleltünk egy-egy elszórtan megjelenő élesztősejtet (22. ábra). Míg a C. albicansszal fertőzött 


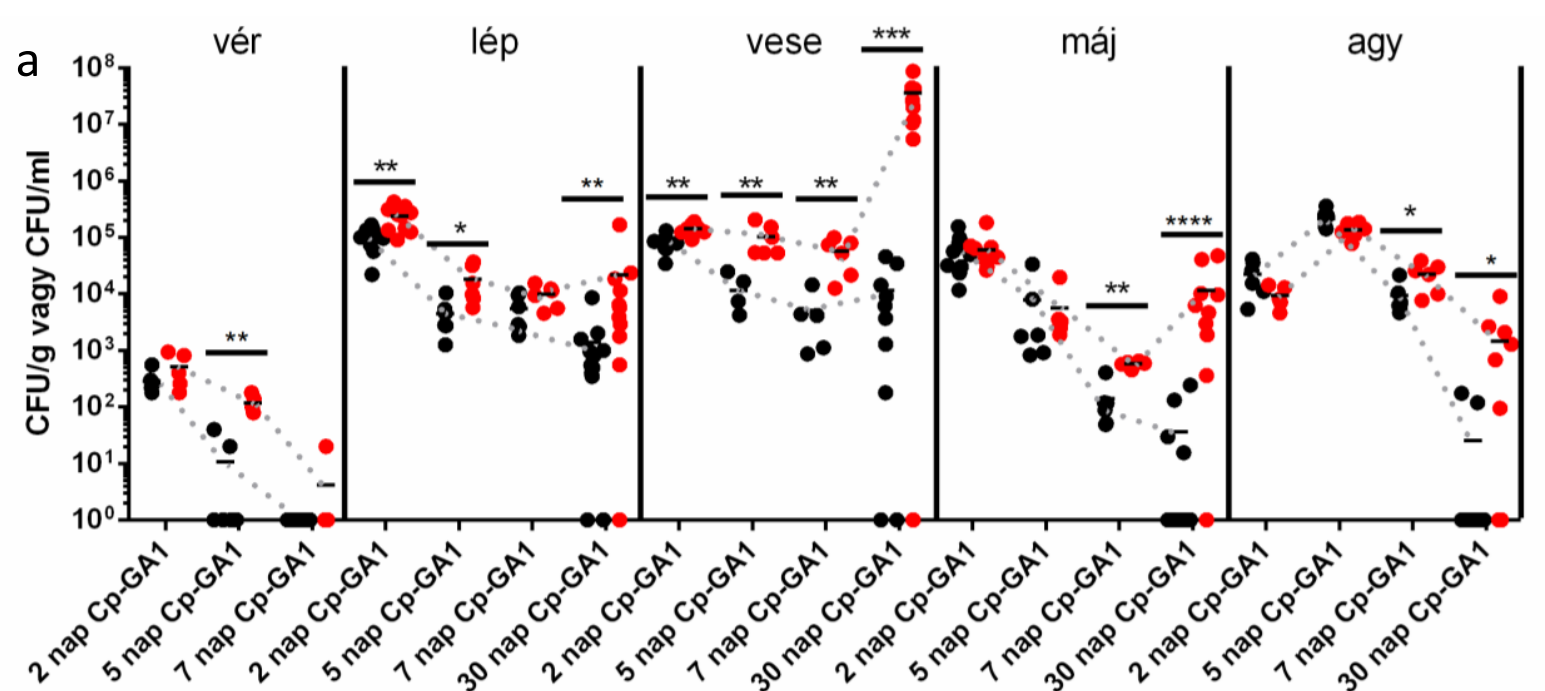

- Vt(Syk) kimérák

- $\mathrm{Syk}^{-/-}$kimérák

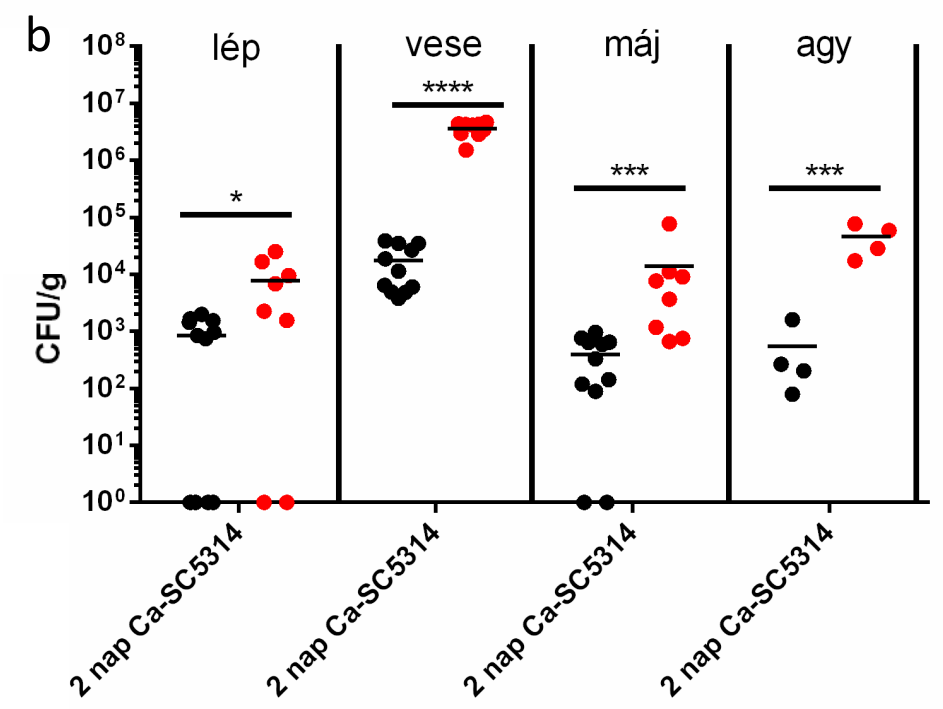

19. ábra. A vér és a különböző szervek kolonizáltsága $\mathrm{Vt}(\mathrm{Syk})$ és $\operatorname{Syk}^{-/-}$kimérákban (a) $C$. parapsilosisszal és (b) C. albicansszal való fertőzés után. Az egereket a $C$. parapsilosis GA1 vagy a $C$. albicans SC5314 törzsével injektáltuk, majd különböző időpontokban a vérből és az egyes szervekből kitenyésztett CFU-kat kvantifikáltuk. Az adatok minden időpontra nézve legalább két független kísérletből származnak. A pontozott vonalak az átlagértékeket (fekete vonal) kötik össze. Cp-: $C$. parapsilosis; Ca-: C. albicans. *: $\mathrm{p}<0,05$; **: $\mathrm{p}<0,01$; ***: $\mathrm{p}<0,001$; ****: $<<0,0001$ (Mann-Whitney próba).

Vt(Syk) és Vt(CARD9) kiméra állatok veséiben nem, vagy csak elvétve figyeltünk meg gomba eredetü képleteket, addig mind a $\mathrm{Syk}^{-/-}$mind a CARD9-/- kimérák veséi intenzíven át voltak szőve hifákkal (22. ábra). 


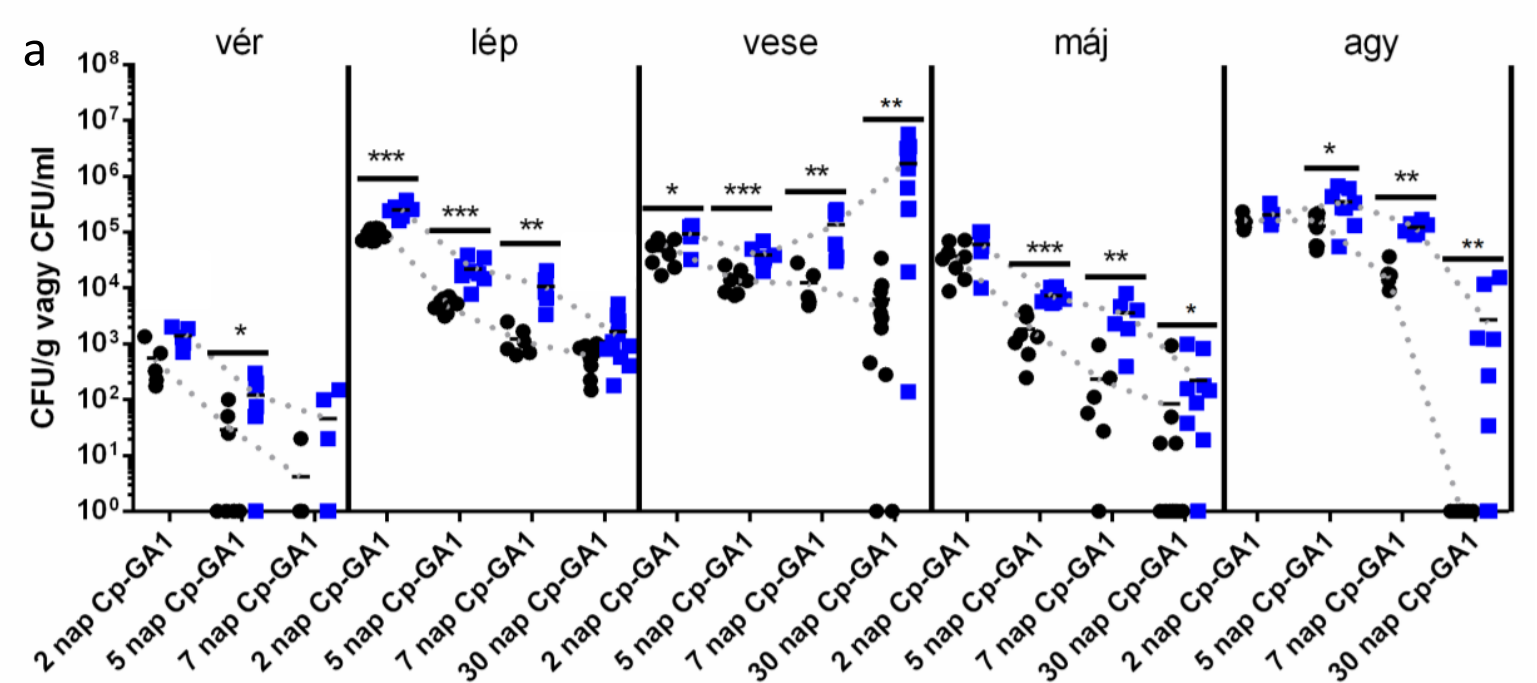

- Vt(CARD9) kimérák

- CARD9 ${ }^{-/}$kimérák

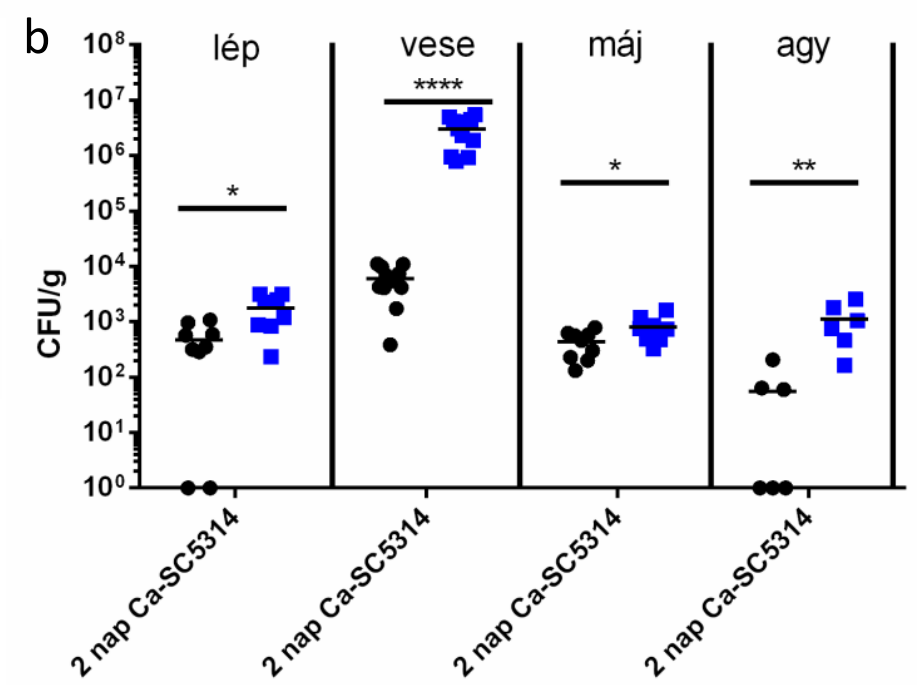

20. ábra. A vér és a különböző szervek kolonizáltsága Vt(CARD9) és CARD9-/ kimérákban (a) $C$. parapsilosisszal és (b) C. albicansszal való fertőzés után. Az egereket a $C$. parapsilosis GA1 vagy a $C$. albicans SC5314 törzsével injektáltuk, majd különböző időpontokban vérböl és az egyes szervekből kitenyésztett CFU-kat kvantifikáltuk. Az adatok minden időpontra nézve legalább két független kísérletből származnak. A pontozott vonalak az átlagértékeket (fekete vonal) kötik össze. Cp-: $C$. parapsilosis; Ca-: C. albicans. *: p<0,05; **: p<0,01; ***: p <0,001; ****: p<0,0001 (Mann-Whitney próba).

Ugyenezen vesékből HE-festett metszeteket is készítettünk, hogy gyulladásra utaló, erősen festődő leukocita beszürődéseket, vagy dezintegrálódott, nekrotikus részeket vizsgáljunk. A C. parapsilosisszal fertőzött állatok veséiben nem találtunk leukocita beszürődéseket. A C. albicansszal fertőzött Vt(Syk) és Vt(CARD9) kiméra állatok veséiben 
a

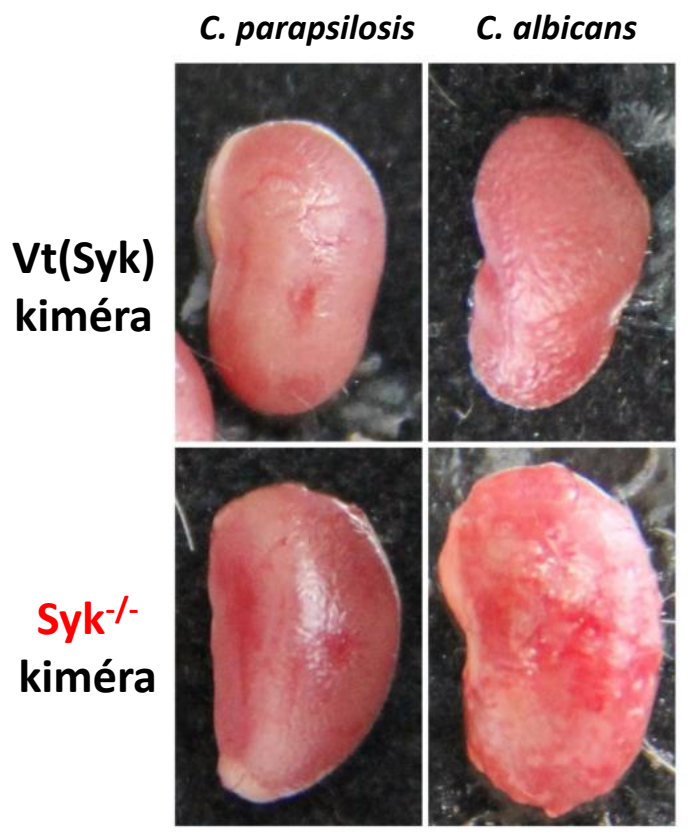

b

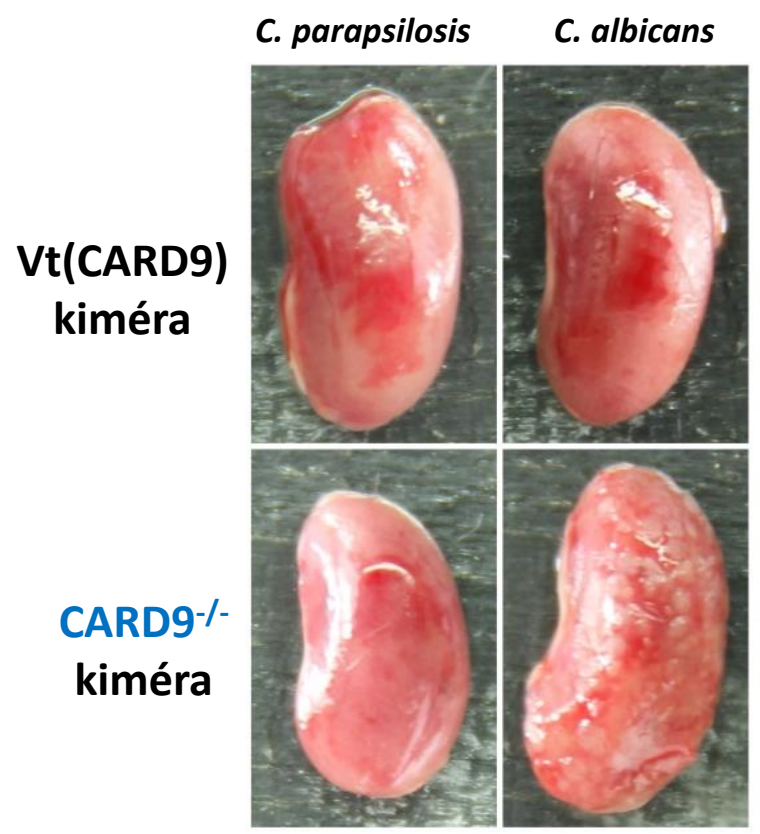

21. ábra. C. parapsilosisszal és C. albicansszal fertőzött (a) $\mathrm{Vt}(\mathrm{Syk})$ és $\mathrm{Syk}^{-/-}$kimérák és (b) Vt(CARD9) és CARD99-- kimérák veséi a fertőzést követő 2. napon. Reprezentatív felvételek.

ritkán kisebb immunsejt csoportokat detektáltunk (23. ábra). A gombafonalakkal átszőtt részeken mind a $\mathrm{Syk}^{-/-}$mind a $\mathrm{CARD}^{-/-}$kimérák veséiben elhalt szövetrészeket, valamint leukocita beszürődéseket figyeltünk meg (23. ábra). A fertőzés után 30 nappal PAS festett metszeteken vizsgáltuk a $C$. parapsilosis jelenlétét a vese szöveteiben. Míg a $\mathrm{Vt}(\mathrm{Syk})$ és Vt(CARD9) kimérák veséiben ezen módszerrel nem észleltünk gombasejteket, addig a Syk ${ }^{-/-}$ és a CARD9- kimérák esetén nagy számú élesztősejtet mutattunk ki (24. ábra).

Az ismertetett eredményekböl azt a következtetést vontuk le, hogy rendszerünkben a hematopoetikus sejtekben expresszálódó Syk és CARD9 hozzájárulnak a szisztémás $C$. parapsilosis fertőzéssel szembeni védekezéshez. Megerősítettük továbbá a Syk/CARD9 jelátvitel alapvető funkcióját a szisztémás $C$. albicans fertőzés elleni védelemben. Whitney és mtsai. (2014) mutatták ki, hogy a Syk dendritikus sejt specifikus deléciója a C. albicansszal fertőzött egerek túlélésének csökkenését okozza. Az Syk ${ }^{-/-}$dendritikus sejtekkel rendelkező állatok veséiben továbbá emelkedett gombakolonizációt és leukocita infiltrációkat mutattak ki. Ezt a fenotípust annak tulajdonították, hogy a dendritikus sejtek Syk hiányában fellépő sérült citokintermelése miatt a neutrofil granulociták fungicid képessége lecsökkent. Saját kísérleteinkben a Syk hiánya a hematopoetikus sejtkészletből szintén fokozott, sőt még kifejezettebb szenzitivitással járt. A hivatkozott tanulmányban ugyanis a dendritikus sejtekre nézve $\mathrm{Syk}^{-/-}$állatok egy része még a fertőzést követő 6. napon is életben volt. Továbbá mi az 


\section{C. parapsilosis}

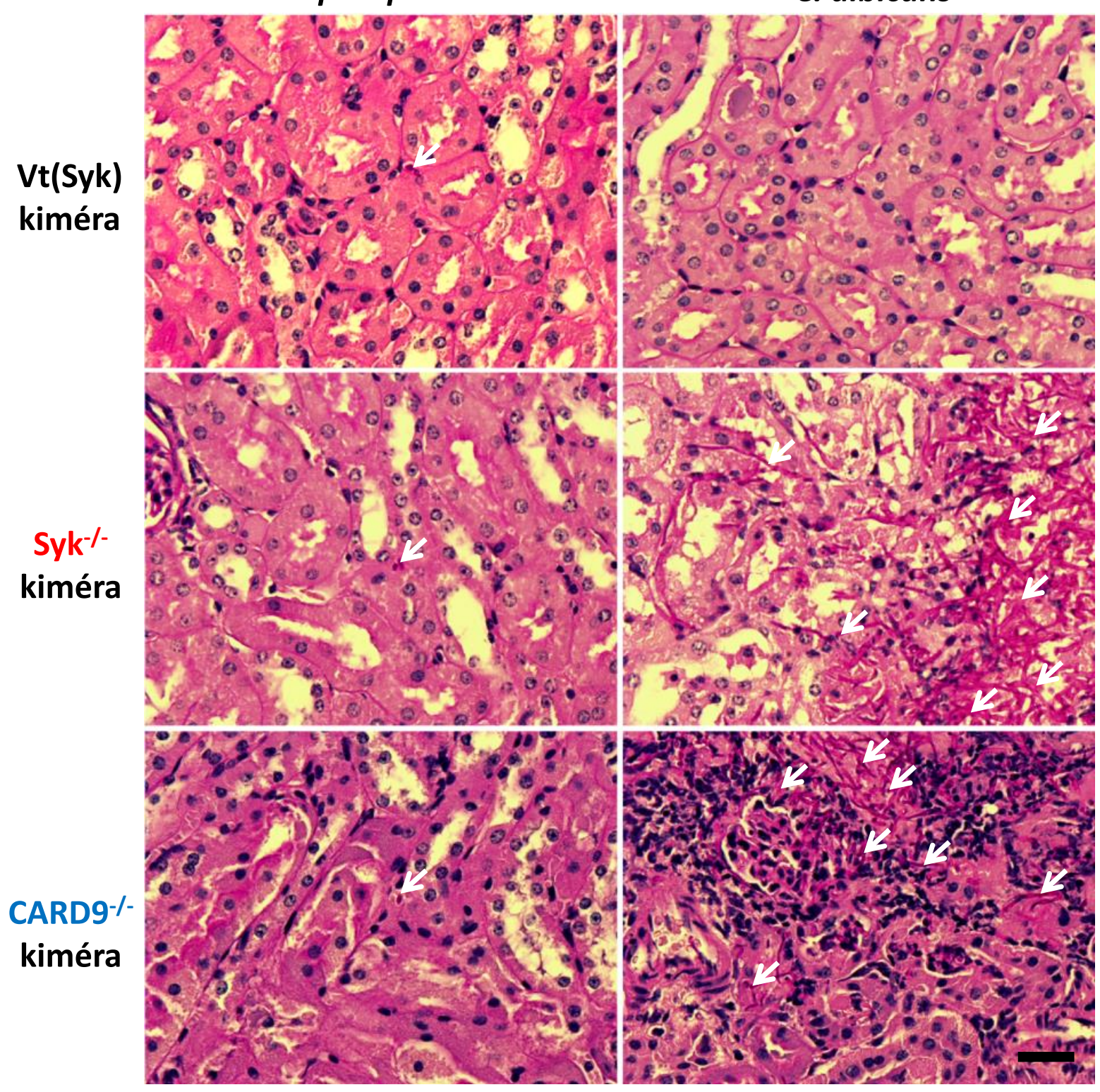

22. ábra. Reprezentatív szövettani felvételek C. parapsilosisszal és $C$. albicansszal fertőzött csontvelöi kimérák veséjéről PAS-festés után. A fényképek a fertőzést követő 2 . napi állapotot mutatják be. A Vt(Syk) és Vt(CARD9) kimérákból származó vesék gombakolonizációjában eltérést nem találtunk, itt a Vt(Syk) kimérák veséinek képeit mutatjuk be. A fehér nyilak PAS pozitív gombaelemeket mutatnak. Skála: $50 \mu \mathrm{m}$.

injektálást követő 2. napon több, mint százszor nagyobb gombakolonizációt találtunk a Syk $^{-/-}$ kimérák veséiben a $\mathrm{Vt}(\mathrm{Syk})$ kimérákhoz képest, míg az említett publikációban ilyen hosszú fertőzés során a különbség alacsonyabb volt. Ez utalhat arra, hogy a Syk nemcsak a dendritikus sejtekben leírt, közvetve a neutrofilekre ható mechanizmussal, hanem egyéb immunsejtek 


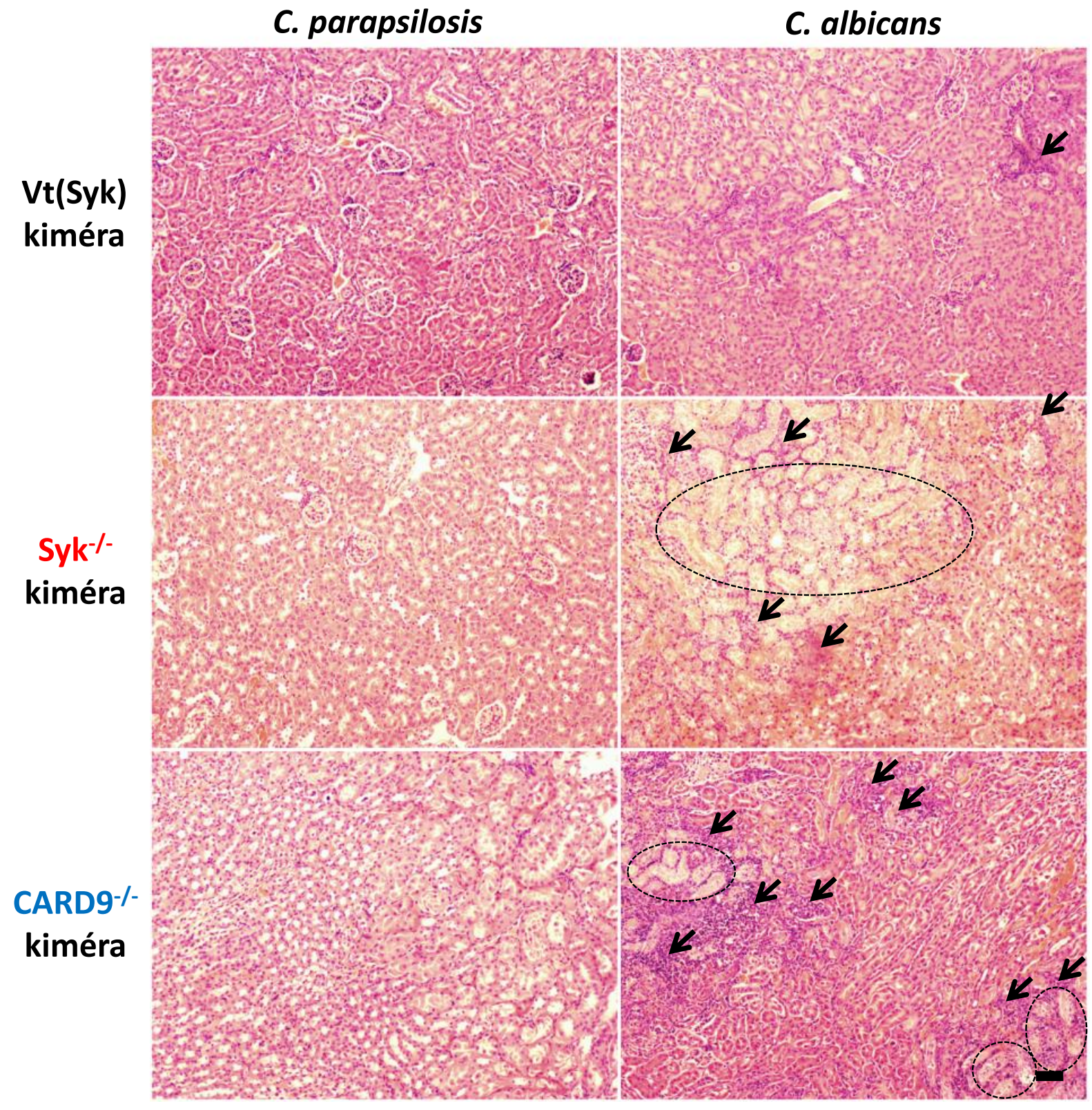

23. ábra. Reprezentatív szövettani felvételek C. parapsilosisszal és C. albicansszal fertőzött különbözö genotípusú csontvelői kimérák veséjéről HE-festés után. A fényképek a fertőzést követő 2. napi állapotot mutatják be. A Vt(Syk) és Vt(CARD9) kimérákból származó vesék hasonló szövettani megjelenésüek voltak, itt a Vt(Syk) kimérák veséinek képeit mutatjuk be. A fekete nyilak immunsejt beszürődésekre mutatnak, a szaggatott vonallal körbevett területeken nekrotikus szövetek jelennek meg. Skála: $200 \mu \mathrm{m}$.

müködése révén is szerepet játszik a $C$. albicans elleni ellenállóképességben. Nem lehet azonban kizárni a módszertani eltérések hatását. A szerzők például az általunk választottnál magasabb fertőzési dózist $\left(2 \times 10^{5}\right.$ élesztősejt/állat) alkalmaztak. 
a

\section{Vt(Syk) kiméra}

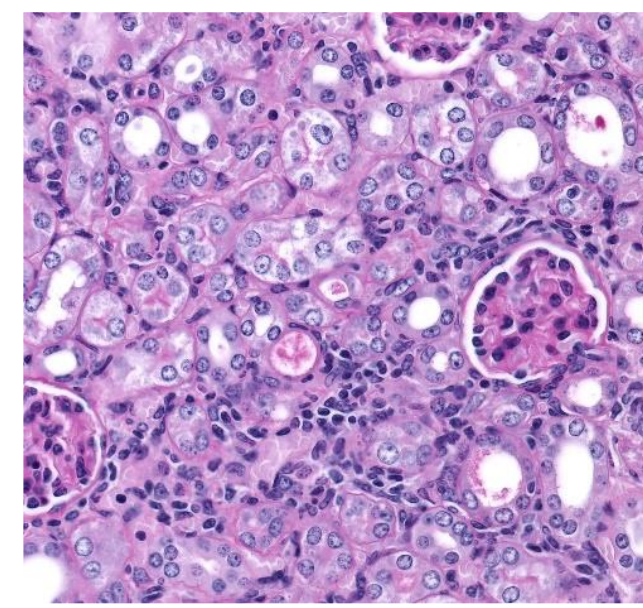

b

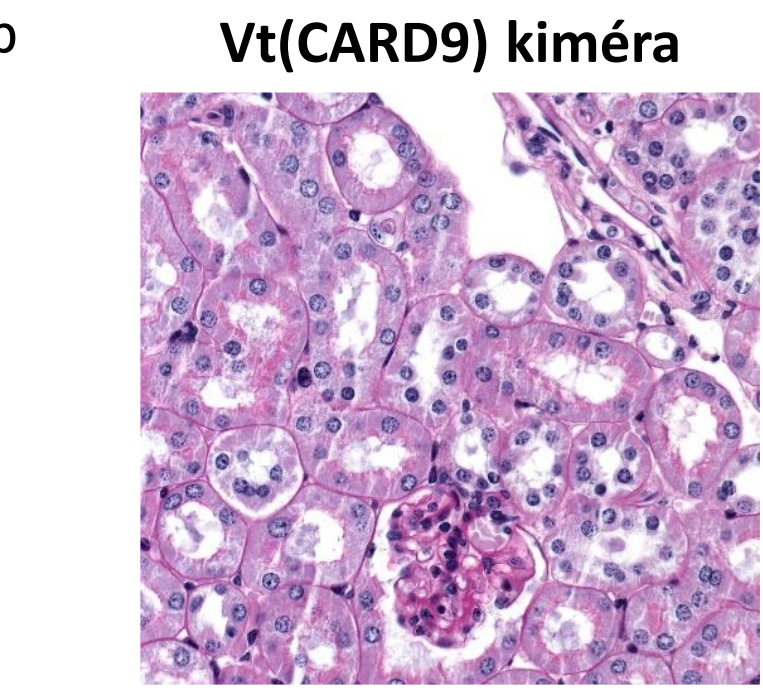

$\mathrm{Syk}^{-/-}$kiméra

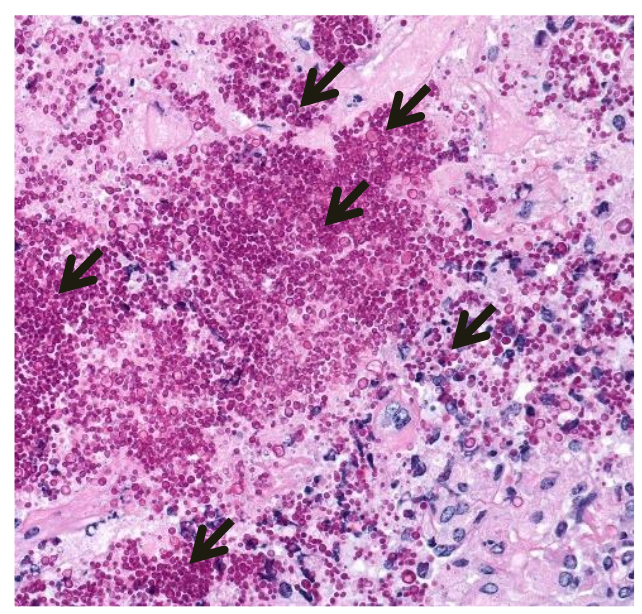

CARD9-/- kiméra

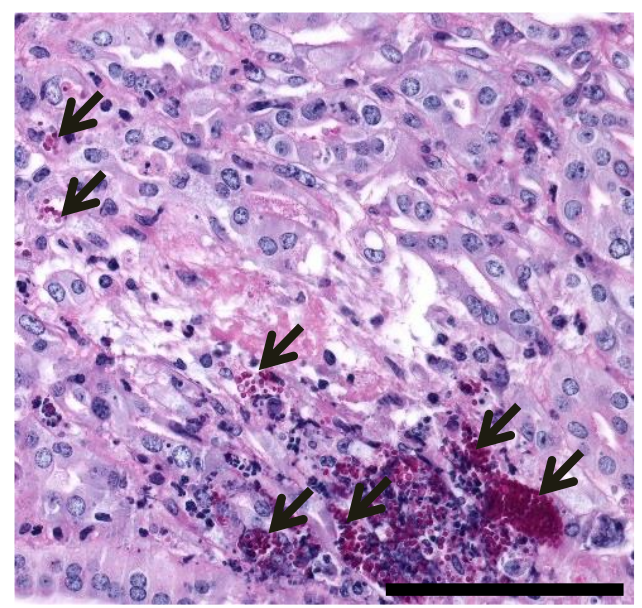

24. ábra. Reprezentatív szövettani felvételek $C$. parapsilosisszal injektált egerek veséjéről 30 nappal a fertőzést követően PAS-festés után. A fekete nyilak PAS pozitív gombaelemeket mutatnak. Skála: $100 \mu \mathrm{m}$.

Megfigyeléseinkkel összhangban több közlemény bemutatta, hogy a CARD9-- egerek C. albicans fertőzés utáni túlélési képessége alacsony, valamint, hogy a CARD9 hiánya magas gomba általi kolonizáltságot eredményez a vesékben (Gross és mtsai. 2006, Jia és mtsai. 2014, Drummond és mtsai. 2015). Az egyik kutatócsoport továbbá a CARD9- egerek veséinek patológiás külső megjelenését is leírta, továbbá a májban és tüdőben is megerősítette a gomba fokozott jelenlétét (Gross és mtsai. 2006). Drummond és mtsai. (2015) pedig a CARD9-/- állatok agyában is magas kolonizációt detektáltak. Kísérletes szisztémás $C$. tropicalis fertőzés után a CARD9 $^{-/-}$állatok szintén korábban elpusztultak Vt társaiknál, valamint a gombaelemek mennyisége ezen rágcsálók veséiben, májában és agyában felülmúlta a Vt állatokban 
megfigyelteket. A mutáns állatok veséiben továbbá kiterjedt leukocita beszürődések jelentek meg (Whibley és mtsai. 2015).

Megemlítendő, hogy szövettani módszerekkel több esetben nem sikerült kimutatnunk gombaelemeket a fertőzött vesékben, annak ellenére, hogy a kitenyésztésen alapuló módszer kvantifikálható módon igazolta a gombák jelenlétét. A két módszer eltérő érzékenységéből adódó jelenség ismert. Mahanty és mtsai. (1988) például szintén $10^{5}$ C. albicans sejttel intravénásan fertőztek egereket, és a PAS-festett vesemetszeteken nem tudtak gombasejteket azonosítani annak ellenére, hogy a tenyésztéses módszerrel kalkulálható volt a gombakolonizáció.

Feltünő, hogy a Vt állatok esetéhez képest a $C$. parapsilosis több nagyságrenddel magasabb kolonizációja a $\mathrm{Syk}^{-/-}$és a CARD9 ${ }^{-/-}$kiméra állatok veséiben, májában és agyában csak 30 nappal a fertőzés után volt megfigyelhető, amely idő elégséges lehet az adaptív immunválasz kialakulásához Vt egerekben. A C. albicans azonban még az adaptív immunválasz kialakulása előtt, már két nappal a fertőzés után több nagyságrenddel nagyobb mennyiségben volt kimutatható a mutáns állatok veséiből a Vt kimérák szöveteihez képest. Nem kizárt, hogy ez a $C$. albicansnak a $C$. parapsilosiséhoz képest önmagában nagyobb virulenciájával hozható összefüggésbe. Azonban arra is utalhat, hogy a szisztémás védekezés terén a Syk/CARD9 jelátvitel szerepe a $C$. albicans elleni veleszületett immunválaszban nyomatékosabb, mint a $C$. parapsilosis elleniben. Lehetséges, hogy a C. parapsilosisszal fertőzött Syk $^{-/-}$és a CARD9-- kimérákban a veleszületett immunválasz egy ideig képes korlátozni a gomba túlélését (lásd. 5. és 7. napi CFU adatok) azonban az adaptív immunitás megfelelő aktivációjának (pl. Syk ${ }^{-/-}$kimérák képtelenek normális antitestes válaszra, illetve a Syk/CARD9 jelátvitelnek szerepe lehet a Th17 sejtes immunitásban) hiányában már képtelen önmagában lépést tartani a szervezethez adaptálódott élesztő elszaporodásával. Egybevág ezzel a feltételezésssel, hogy az adaptív immunitással nem rendelkező SCID egerek szerveiben (lép, vese, máj, agy) magasabb C. parapsilosis kolonizációt tapasztaltunk 30 nappal a fertőzést követően, mint a Vt egerek esetén. Az adaptív immunválasz hiányában egyetlen olyan SCID egeret sem figyeltünk meg, amelynek bármely vizsgált szervéből teljesen eliminálódott a $C$. parapsilosis ebben az időpontban, míg több Vt egér esetén a $C$. parapsilosis jelenlétét már nem tudtuk kimutatni a lépben, a májban és az agyban (nem publikált adat). Emiatt feltételezhető, hogy a $C$. parapsilosis fertőzés eliminációjához a veleszületett és az adaptív immunmechanizmusok együttese szükséges. Ismert, hogy a $C$. parapsilosis képes adaptív immunfolyamatok kiváltására. Például rekombináns antitestekkel gátolható a C. parapsilosis elszaporodása a szervezetben (Matthews és mtsai. 2003), és Th-sejtes immunválaszokat is 
kimutattak ezen faj kapcsán (Tóth és mtsai. 2013). A C. parapsilosis elleni adaptív immunválaszok, és ezen belül a Syk/CARD9 út jelentőségének pontos feltárása a jövő egyik fontos feladata lesz.

A korábbi tanulmányokkal összevetve munkánk jelentősége, hogy tudomásunk szerint először mi vizsgáltuk Syk $^{-{ }^{-}}$és a CARD9 ${ }^{-/-}$csontvelői kimérák segítségével a Syk és CARD9 Candida fajokkal szembeni szervezetszintü védekezésben betöltött szerepét. Whitney és mtsai. (2014) kísérleti egereiben ugyanis a Syk csupán egy dendritikus sejtek alkotta sejtpopulációból hiányozott. Bár Drummond és mtsai. (2015) is alkalmaztak csontvelöi kimérákat a CARD9 tanulmányozására $C$. albicans fertőzés során, azonban ők ún. vegyes csontvelői kimérákkal dolgoztak. Ezekbe az állatokba a besugárzást követően Vt és CARD9 ${ }^{-/-}$csontvelöi sejtek keverékét transzplantálták. A többi vizsgálatban viszont olyan állatokat használtak fel, amelyek minden testi sejtjéből hiányzott a CARD9 (Gross és mtsai. 2006, Jia és mtsai. 2014 és Drummond és mtsai. 2015, Whibley és mtsai. 2015). A Candidákkal szembeni érzékenységet ezért nem lehetett egyértelműen kizárólag az immunsejtek defektusainak tulajdonítani, mivel Syk/CARD9-en keresztül szignalizáló receptorokat nem csupán hematopoetikus eredetü sejtek expresszálhatnak (Heyl és mtsai. 2014).

Thompson és mtsai. (2019) szintén egér modellben vizsgálták a Dectin-1 szerepét a $C$. parapsilosisszal szembeni rezisztenciában. Munkájukban a $C$. parapsilosis fertőzés során a Dectin- $1^{-/-}$állatok gomba általi kolonizáltsága csak a rövidebb fertőzési időpont (7 nap) esetén volt magasabb a vad típúsúakénál, míg hosszabb időtartam alkalmazásakor (21 nap) ez a különbség megszünt. Laborunk vizsgálataiban pedig a Dectin-1/- egerek nem voltak érzékenyebbek a $C$. parapsilosisszal szemben, mint a vad típusúak (nem publikált adat, Csonka 2018). A jelen dolgozatban bemutatott Syk $^{-/-}$és CARD9-- kimérák ezzel szemben érzékeny fenotípussal rendelkeztek $C$. parapsilosis fertőzést követően, amely a fertőzést követő 30 . napra tovább fokozódott. Ezek alapján indokolt feltételezni a Dectin-1-től eltérő, Syk/CARD9 útvonalon szignalizáló receptorok (Dectin-2, Dectin-3, Mincle, CR3) részvételét a $C$. parapsilosisszal szembeni szervezetszintü védekezésben. Ennek tisztázására azonban további kutatások szükségesek. 


\section{VII. Összefoglalás}

Az invazív gombás fertőzések jelentős egészségügyi problémát jelentenek. Évente 1,5 millió embert hoznak életveszélyes állapotba világszerte. A kialakító kórokozók közül kiemelt fontossággal bírnak a Candida nemzetség opportunista humánpatogén fajai. Ezek évente 400000-700000 új invazív kórképet okoznak, melyek mortalitása 46-75\%. Bár a csoport klinikailag legjelentősebb faja a C. albicans, növekvő incidenciával jelennek meg a nonalbicans fajok (pl. C. parapsilosis, C. glabrata, C. tropicalis, C krusei) okozta infekciók. A C. parapsilosis a kandidémiás betegekből egyik leggyakrabban izolált gombafaj. Biofilmképzése miatt a parenterális táplálásban részesülő, vagy más orvosilag behelyezett eszközzel kezelt páciensek fokozottan ki vannak téve az általa okozott fertőzéseknek. Továbbá az újszülötteket érintő kandidiázisok 1/3-át ez a faj eredményezi.

Mivel az invazív gombás fertőzések elsősorban legyengült immunitású egyénekben fejlődnek ki, sürgető a gombaellenes immunválasz vizsgálata. Részletes megismerése ugyanis megalapozza a hagyományos gyógyszeres kezeléseket kiegészítő antifungális immunterápiákat. Mára számos elemét azonosították a Candida-ellenes védelemnek. Az ismeretek többsége azonban a C. albicansszal kapcsolatos kutatásokból származik és keveset tudunk az immunrendszer és a non-albicans fajok kölcsönhatásairól. Mivel a kiváltott immunválasz akár az azonos nemzetségbe sorolt patogén gombák esetén is eltérő lehet, szükség van faji szintü feltárásukra.

A C. albicans ellenes immunitás egyik központi eleme a Syk és a CARD9 fehérjék által mediált szignalizáció. Ez az útvonal egyes gomba eredetű PAMP-okat felismerő PRR-ek jelátvitelét közvetíti, amely különböző effektor funkciókat aktivál. Az utóbbi években a $C$. tropicalis és a $C$. glabrata kapcsán is bizonyították a Syk vagy a CARD9 részvételét az immunológiai folyamatokban. A C. parapsilosis fertőzések esetén azonban alig ismert ezen komponensek jelentősége.

Ezért célul tüztük ki a Syk és CARD9 szerepének vizsgálatát $C$. parapsilosis fertőzés során. Elöször összehasonlítottuk a C. parapsilosisszal koinkubált Syk $^{-/-}$és CARD9-- egér makrofágok (BMDM-ek és több esetben PM-ek) válaszreakcióit a kontroll Vt(Syk) és Vt(CARD9) sejtekével. Később invazív kandidiázis modellben vizsgáltuk, hogy $\mathrm{Syk}^{-/-}$és CARD9 ${ }^{-/-}$csontvelői kiméra egerek érzékenyebb fenotípust mutatnak-e $C$. parapsilosis fertőzés során, mint a kontroll kimérák. Referenciaként a legtöbb kísérletet egy C. albicans törzs felhasználásával is elvégeztük. 
Eredményeink az alábbiak szerint foglalhatók össze (Függelék 3. táblázat):

\section{A C. parapsilosisszal fertőzött BMDM-ekben az NF-кB sejtmagi transzlokációja Syk- és CARD9-függő módon valósul meg}

Elöször C. parapsilosis törzsekkel stimulált BMDM-ekben vizsgáltuk az NF-kB p65 alegységének sejtmagba történő transzlokációját, melyet immunfestést követő képalkotó áramlási citometriával kiviteleztünk. Azt tapasztaltuk, hogy a fertőzött Syk ${ }^{-/}$és a CARD9sejtekben kevésbé hatékonyan ment végbe a p65 nukleáris transzlokációja, mint a Vt(Syk) és Vt(CARD9) makrofágokban. A pozitív kontrollként alkalmazott LPS-sel kezelt Syk $^{-/-}$és a CARD9 $^{-/-}$sejtekben azonban nem csökkent a transzlokáció mértéke a Vt(Syk) és Vt(CARD9)

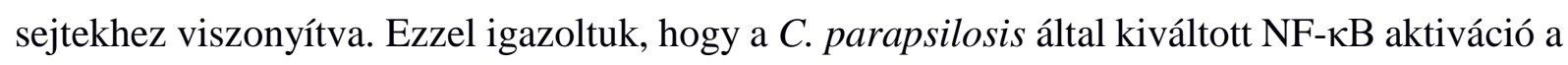
Syk/CARD9 útvonal szabályozása alatt áll BMDM-ekben.

\section{A C. parapsilosis által kiváltott citokinválasz a Syk és CARD9 által regulált folyamat egér makrofágokban}

Először a Proteome Profiler Mouse Cytokine Array Panel A, majd ELISA segítségével vizsgáltuk a BMDM-ek C. parapsilosis törzsekkel történő stimulációjakor kialakuló citokintermelését. Összehasonlításképpen az SC5314 C. albicans törzset is bevontunk a kísérletbe. Eredményeink azt mutatták, hogy a Syk ${ }^{-/-}$és a CARD9-/- sejtek TNF $\alpha$ termelése minden alkalmazott Candida törzs esetén alacsonyabb volt a $\mathrm{Vt}($ Syk) és a $\mathrm{Vt}(\mathrm{CARD} 9)$ makrofágokénál. Míg a $C$. parapsilosszal koinkubált Syk ${ }^{-/-}$BMDM-ek kemokin (KC, MIP-1 $\alpha$ és MIP-2) termelése ép volt, addig a $C$. albicansszal fertőzötteké elmaradt a Vt(Syk) sejtekétől. A CARD9-- BMDM-ek kemokin termelése azonban nemcsak a $C$. albicansszal, hanem a $C$. parapsilosisszal történő kezelés esetén is sérült volt. A PM-ek esetében mind a Syk ${ }^{-{ }^{-}}$, mind a $\mathrm{CARD}^{-/-}$sejtekben a $C$. parapsilosis és a $C$. albicans által indukált TNF $\alpha$ - és kemokintermelés defektusát figyeltük meg. Eredményeink összességében arra utalnak, hogy az egér makrofágok C. parapsilosis fertőzésre adott citokinválasza a Syk és a CARD9 befolyása alatt áll. Megerősítettük továbbá ezen jelátviteli út szerepét a $C$. albicans által kiváltott citokintermelésben. Emellett fajspecifikus eltéréseket is azonosítottunk.

3. A $C$. parapsilosis és a $C$. albicans egér makrofágok általi bekebelezése Syk-függő, de CARD9-független folyamat

Képalkotó áramlási citometriával vizsgáltuk Alexa Fluor ${ }^{\circledR} 488$-cal/GFP-vel jelölt $C$. parapsilosis és C. albicans sejtek makrofágok általi fagocitózisát. A Syk ${ }^{-/-}$BMDM-ek és PM- 
ek kevésbé hatékonyan fagocitálták mindkét Candida faj sejtjeit, mint a Vt(Syk) sejtek. A CARD9 ${ }^{-/-}$BMDM-ek és PM-ek azonban a Vt(CARD9) makrofágokhoz hasonló mértékben internalizálták mind a $C$. parapsilosist mind a $C$. albicanst. A makrofágok Candida sejteket fagocitáló képessége tehát Syk-függőnek, de CARD9-függetlennek bizonyult.

\section{A C. parapsilosist tartalmazó fagoszómák savasodása Syk-függő, de CARD9-független úton megy végbe egér makrofágokban}

Ebben a kísérletben Alexa Fluor ${ }^{\circledR}$ 488-cal/GFP-vel, továbbá egyidejüleg a pHrodo ${ }^{\mathrm{TM}}$ Red pH-szenzitív fluorofórral jelöltünk $C$. parapsilosis és $C$. albicans sejteket. Az utóbbi festék a savasodott fagoszómákban intenzíven fluoreszkál. A makrofágokat ezekkel az élesztő sejtekkel koinkubáltuk, majd képalkotó áramlási citométerrel vizsgáltuk a pHrodo ${ }^{\mathrm{TM}} \mathrm{Red}^{+}$ makrofágok arányát az Alexa Fluor ${ }^{\circledR} 488^{+} / \mathrm{GFP}^{+}$makrofágok arányának százalékában. Ez az érték a C. parapsilosis törzsekkel fertőzött $\mathrm{Syk}^{-/-} \mathrm{BMDM-ek}$ és PM-ek esetében alacsonyabb volt a $\mathrm{Vt}(\mathrm{Syk})$ sejtekénél. A $C$. albicansszal kezelt $\mathrm{Syk}^{-/-}$makrofágok hasonló eredményeket mutattak. A CARD9 hiánya azonban nem volt hatással erre az értékre. Ezért azt a következtetést vontuk le, hogy a $C$. parapsilosis tartalmú fagoszómák savasodása egy Syk által szabályozott folyamat, amely nem függ a CARD9-től. Megerősítettük továbbá a C. albicans tartalmú fagoszómák savasodásának Syk-függését.

\section{A C. parapsilosis BMDM-ek általi eliminációja Syk-függő, de CARD9-független}

A továbbiakban élő csíraszám meghatározás segítségével vizsgáltuk a különböző genotípusú makrofágok $C$. parapsilosist elimináló képességét. Míg a Syk ${ }^{-/-}$BMDM-ek kevésbé hatékonyan eliminálták a $C$. parapsilosist, mint a Vt(Syk) sejtek, addig a CARD9 jelenléte nem volt hatással erre a folyamatra. A Syk ${ }^{-/}$és a CARD9 ${ }^{-/-}$PM-ek esetén nem mutattunk ki defektust az eliminációs aktivitásban.

\section{A Syk ${ }^{-/-}$és a CARD9-/- csontvelői kiméra egerek érzékeny fenotípussal jellemezhetők invazív $C$. parapsilosis és $C$. albicans fertőzés során}

Miután in vitro megalapoztuk, hogy a Syk/CARD9 jelátvitel részt vesz a $C$. parapsilosis immunológiai felismerérében, vizsgálni kívántuk, hogy egér modellszervezetben hozzájárul-e az ezen élesztő által kiváltott invazív fertőzéssel szembeni ellenállóképességhez. Ezért $C$. parapsilosisszal intravénás úton injektált állatok szerveiből (lép, vese, máj és agy) és véréből a fertőzést követő 2.,5.,7., és 30. napon élőcsíraszámot határoztunk meg. Mivel a C. albicansszal beoltott Syk $^{-/-}$és CARD9-/- csontvelői kimérák a későbbi időpontokat nem érték meg, ezek és 
Vt kontrolljaik szöveteiben csak a kezelés utáni 2. napon vizsgáltuk a gombakolonizációt. A $\mathrm{Syk}^{-/-}$és CARD9 ${ }^{-/-}$csontvelői kimérák szerveiben legalább egy nagyságrenddel nagyobb (vese, agy) C. albicans általi kolonizációt észleltünk, mint Vt kimérák szerveiben. Hisztológiai vizsgálattal megerősítettuik a $C$. albicans elburjánzását a Syk $^{-/}$és a CARD9 ${ }^{-/-}$kimérák veséiben, ahol nekrotikus és gyulladásra utaló területeket is azonosítottunk. Ezen vesék makroszkopikusan is patológiás megjelenést mutattak. A C. parapsilosisszal fertőzött Syk $^{-/-}$ illetve CARD9-/- kimérákból minden vizsgálati időpontban szignifikánsan nagyobb mértékü gomba általi kolonizációt mutattunk ki, mint a Vt kimérákból, azonban ezen különbség volumene csak a fertőzést követő 30. napon érte el a több ( 2-3) nagyságrendet. Ezen időpontban szövettani módszerekkel is kimutatható volt a $C$. parapsilosis sejtek elszaporodása a mutáns állatok veséiben. Összességében megerősítettük a Syk és CARD9 alapvető funkcióját a $C$. albicans elleni rezisztenciában, és megállapítottuk, hogy a $C$. parapsilosisszal szemen mutatott ellenállóképesség komponensei is.

Eredményeink hozzájárulnak a $C$. parapsilosis fertőzések immunológiai hátterének megismeréséhez. Kimutattuk, hogy a Syk és CARD9 fehérjék részt vesznek az ezen gomba elleni immunológiai védekezésben. Megerősítettük továbbá, hogy ezek a fehérjék nélkülözhetetlen elemei a $C$. albicansszal szembeni immunitásnak. Tudomásunk szerint először alkalmaztunk csontvelői Syk $^{-/-}$illetve CARD9-/- kimérákat mind a $C$. parapsilosis, mind a $C$. albicans által kiváltott immunválaszok tanulmányozására. Továbbá egyes eredményeink arra utalhatnak, hogy lehetnek eltérések a $C$. parapsilosis és a $C$. albicans által kiváltott válaszok Syk és CARD9 általi szabályozásában. Szakirodalmi ismeretek alapján eredményeink a Dectin-2, a Dectin-3, a Mincle és a CR3 receptorok $C$. parapsilosisszal összefüggő, valamint a Syk/CARD9 jelátvitel potenciális Candida-ellenes immunterápiás célpontként történő vizsgálata felé mutatnak. 


\section{Summary}

Invasive fungal disease is a global concern threatening the lives of annually $\sim 1.5$ million people. The opportunistic human pathogens within the genus Candida are a major cause. These yeasts lead to $400,000-700,000$ new invasive infections annually with a mortality of 46-75\%. Although $C$. albicans remains the most clinically relevant species, the incidence of non-albicans species (e.g. C. parapsilosis, C. glabrata, C. tropicalis, C. krusei) is on the rise. C. parapsilosis is one of the most frequent fungi isolated from candidemia. Due to its biofilm formation, patients receiving parenteral nutrition or are treated with other prosthetic devices are at increased risk of developing disease. Furthermore, 1/3 of all candidiases affecting neonates are caused by this species.

Invasive fungal infections manifest predominantly in those with impaired immunity. Thus, the study of antifungal immunity is relevant as it is the foundation of immune therapies complementing treatment with antifungal drugs. Much of anti-Candida immunity has been explored to date. However, most scientific interest has focused on C. albicans while little is known about the interaction of the mammalian immune system with non-albicans species. As immune responses triggered by species within even the same genus may differ, it is important to identify these processes in a species-specific manner.

Signaling through Syk and CARD9 is a crucial component of immunity against $C$. albicans. This pathway mediates signals from PRRs binding fungal PAMPs and activates effector mechanisms. The involvement of either Syk or CARD9 in the immune recognition of C. tropicalis and C. glabrata has also been established recently. However, the relevance of these proteins in relation to $C$. parapsilosis remains largely unidentified.

Therefore, the aim of this thesis was to examine the role of Syk and CARD9 in the context of $C$. parapsilosis infections. First, we compared the responses of $C$. parapsilosis challenged $\mathrm{Syk}^{-/-}$or CARD9 ${ }^{-/-}$murine macrophages (BMDMs and on multiple occasions PMs) with those of control $\mathrm{Wt}(\mathrm{Syk})$ and $\mathrm{Wt}(\mathrm{CARD} 9)$ cells. Then we investigated the susceptibility of $\mathrm{Syk}^{-/-}$or $\mathrm{CARD}^{-/-}$bone marrow chimeric mice to C. parapsilosis invasive infection. Most experiments were also performed using a $C$. albicans reference strain. 
Our results are summarized below:

1. Nuclear translocation of NF-кB p65 upon infection with $C$. parapsilosis is dependent on Syk and CARD9

Firstly, we implemented immune staining and subsequent imaging flow cytometry to reveal the nuclear translocation of NF-кB p65 in BMDMs stimulated with $C$. parapsilosis strains. We detected decreased translocation in $\mathrm{Syk}^{-{ }^{-}}$and CARD9 ${ }^{-/-}$macrophages compared to $\mathrm{Wt}(\mathrm{Syk})$ and $\mathrm{Wt}(\mathrm{CARD} 9)$ cells. However, the absence of Syk or CARD9 did not hinder the translocation in BMDMs treated with LPS as positive control. Thus, NF-kB activation in $C$. parapsilosis infected BMDMs is regulated by the Syk/CARD9 pathway.

\section{Syk and CARD9 regulate cytokine production of $C$. parapsilosis challenged murine macrophages}

We investigated the cytokine expression of $C$. parapsilosis stimulated BMDMs by the Proteome Profiler Mouse Cytokine Array Panel A and by ELISA. For comparison, we also included the $C$. albicans strain in this experiment. Regardless of Candida strains or species, TNF $\alpha$ synthesis proved to be lower in $\mathrm{Syk}^{-/-}$and CARD9 ${ }^{-/-}$macrophages than in $\mathrm{Wt}(\mathrm{Syk})$ and Wt(CARD9) cells. While chemokine production (KC, MIP-1 $\alpha$ and MIP-2) of C. parapsilosis treated $\mathrm{Syk}^{-/-}$BMDMs was intact, $C$. albicans infected cells of this genotype yielded less chemokines than Wt(Syk) BMDMs. However, CARD9-/- BMDMs were characterized by compromised chemokine production irrespective of Candida species. We then studied the cytokine production of PMs. In this case, $\mathrm{Syk}^{-/-}$and CARD9 ${ }^{-/-}$cells failed to produce both TNF $\alpha$ and chemokines as sufficiently as $\mathrm{Wt}(\mathrm{Syk})$ and $\mathrm{Wt}(\mathrm{CARD} 9)$ PMs. All in all, these results suggest that the cytokine response of murine macrophages to $C$. parapsilosis is dependent on Syk and CARD9. We also confirmed the importance of this signaling pathway in the cytokine production triggered by $C$. albicans. Additionally, we observed some species-specific differences.

\section{Phagocytosis of $C$. parapsilosis and $C$. albicans by murine macrophages is Syk- dependent but CARD9-independent}

Using imaging flow cytometry, we monitored the phagocytosis of Alexa Fluor ${ }^{\circledR}$ 488/GFP labelled C. parapsilosis and C. albicans cells by macrophages. Syk $^{-1-}$ BMDMs and PMs internalized the yeast cells of both species less effectively than their $\mathrm{Wt}(\mathrm{Syk})$ counterparts. 
On the other hand, CARD9 $9^{-/-}$macrophages ingested both species normally. The phagocytic capacity of murine macrophages was therefore Syk-dependent but CARD9-independent.

\section{Syk but not CARD9 affects the acidification of $C$. parapsilosis containing phagosomes in murine macrophages}

In this experiment, we implemented dual staining of $C$. parapsilosis and C. albicans cells with Alexa Fluor ${ }^{\circledR}$ 488/GFP plus pHrodo ${ }^{\text {TM }}$ Red, a stain emitting bright fluorescence within acidified phagosomes. Macrophages were coincubated with these yeast cells and the proportion of $\mathrm{pHrodo}^{\mathrm{TM}} \mathrm{Red}^{+}$macrophages as percentage of the proportion of Alexa $488^{+} / \mathrm{GFP}^{+}$ macrophages was assessed. This value was lower for C. parapsilosis or C. albicans infected $\mathrm{Syk}^{-/-}$BMDMs and PMs than for Wt(Syk) cells. However, the absence of CARD9 had no effect on this feature. Therefore, we concluded that the acidification of phagosomes containing $C$. parapsilosis cells is controlled by Syk but is not affected by CARD9. Furthermore, we have confirmed that this process is also Syk-dependent in the case of $C$. albicans.

\section{Killing of $C$. parapsilosis by BMDMs depends on Syk but not CARD9}

We then studied the elimination of $C$. parapsilosis by macrophages by CFU determination after coincubation. While Syk $^{-/-}$BMDMs killed C. parapsilosis less efficiently than $\mathrm{Wt}(\mathrm{Syk})$ cells, CARD9 did not affect this process. In the case of PMs, however, the killing ability was not defective in either $\mathrm{Syk}^{-/-}$or $\mathrm{CARD9} 9^{-/-}$cells.

\section{Syk $^{-/-}$and CARD9-/- bone marrow chimeric mice are susceptible to invasive $C$. parapsilosis and $C$. albicans infections}

Having established the in vitro participation of Syk/CARD9 signaling in the immunological recognition of $C$. parapsilosis, we sought to determine if it also contributes to resistance to invasive infection caused by this species in a mouse model. Therefore, we retrieved CFUs from selected organs (spleen, kidneys, liver, brain) and the blood of animals intravenously injected with C. parapsilosis on days 2, 5, 7 and 30 post-infection. As C. albicans infected $\mathrm{Syk}^{-/-}$and CARD9 ${ }^{-/-}$chimeras did not survive until the later time points, these and their Wt controls were assessed for fungal burden on day 2 post-infection. Colonization by $C$. albicans in organs in $\mathrm{Syk}^{-/-}$and $\mathrm{CARD9}^{-/-}$chimeras was at least 1 order of magnitude higher (brains, kidneys) than in those of Wt chimeras. Excessive growth of this yeast in the kidneys of $\mathrm{Syk}^{-/-}$and CARD9 ${ }^{-/-}$chimeras was confirmed by histological observations and we also detected necrotic areas and signs of inflammation. The gross morphology of these kidneys appeared 
pathological. The fungal burden in C. parapsilosis infected $\mathrm{Syk}^{-/-}$or CARD9 ${ }^{-/-}$chimeras surpassed that of respective Wt ones. The extent of this difference was multiple orders of magnitude on day 30 post-infection. At this time point, expansive growth of $C$. parapsilosis could be visualized in the kidneys of the mutant mice. To conclude, we confirmed the profound role of Syk and CARD9 in the resistance against $C$. albicans and proved that they are also involved in the systemic resistance against $C$. parapsilosis.

This thesis contributes to our knowledge on the immunological background of $C$. parapsilosis infections. We have demonstrated that Syk and CARD9 take part in the immunological defense against $C$. parapsilosis. We have also confirmed that they are indispensable elements of anti-C. albicans immunity. To our knowledge, this was the first example to utilize $\mathrm{Syk}^{-/-}$and CARD9-/- bone marrow chimeras to examine immune responses triggered by $C$. albicans or $C$. parapsilosis. Moreover, some of our results suggest that Syk and CARD9 might regulate responses to these species differently. Combined with literature data, our findings point towards the potential of future research on Dectin-2, Dectin-3, Mincle and CR3 in relation to $C$. parapsilosis and on the Syk/CARD9 pathway as a target for anti-Candida immune therapy. 


\section{Irodalomjegyzék}

Almeida, F., Wolf, J. M., da Silva, T. A., DeLeon-Rodriguez, C. M., Rezende, C. P., Pessoni, A. M., Fernandes, F. F., Silva-Rocha, R. S., Martinez, R., Rodrigues, M. L., Roque-Barreira, M. C. és Casadevall, A. (2017): Galectin-3 impacts Cryptococcus neoformans infection through direct antifungal effects. Nature Communications, 8:1968. doi:10.1038/s41467-017-02126-7

ÁNTSZ (2004): Az ÁNTSZ hálózat mikológiai laboratóriumai 2004. évi munkájának értékelése. In: Az Állami Népegészségügyi és Tisztiorvosi Szolgálat, valamint az egyetemek és kórházak 2004. évi járványügyi-klinikai-mikrobiológiai és DDD munkájának értékelése. IV. fejezet:1-14.

ÁNTSZ (2005): Az ÁNTSZ hálózat mikológiai laboratóriumai 2005.-évi munkájának értékelése. Jelentés.

ÁNTSZ (2006): Az ÁNTSZ hálózat mikológiai laboratóriumai 2006.-évi munkájának értékelése. Jelentés.

ÁNTSZ (2008): ÁNTSZ regionális hálózat mikológiai laboratóriumai 2008.-évi munkájának értékelése. Jelentés.

ÁNTSZ (2009): ÁNTSZ regionális hálózat mikológiai laboratóriumai 2009.-évi munkájának értékelése. Jelentés.

ÁNTSZ (2011): A Népegészségügyi Szakigazgatási Szervek mikológiai laboratóriumai 2011.-évi munkájának értékelése. Jelentés.

ÁNTSZ (2012): A Népegészségügyi Szakigazgatási Szervek mikológiai laboratóriumai 2012.-évi munkájának értékelése. Jelentés.

ÁNTSZ (2014): A Népegészségügyi Szakigazgatási Szervek mikológiai laboratóriumai 2014.-évi munkájának értékelése. Jelentés.

Arendrup, M. C. (2010): Epidemiology of invasive candidiasis. Current Opinion in Critical Care, 16(5):445-452. doi:10.1097/mcc.0b013e32833e84d2

Arendrup, M. C., Bruun, B., Christensen, J. J., Fuursted, K., Johansen, H. K., Kjældgaard, P., Knudsen, J. D., Kristensen, L., Møller, J., Nielsen, L., Rosenvinge, F. S., Røder, B., Schønheyder, H. C., Thomsen, M. K. és Truberg, K. (2011): National Surveillance of Fungemia in Denmark (2004 to 2009). Journal of Clinical Microbiology, 49(1):325-334. doi:10.1128/jcm.01811-10

Armstrong-James, D. és Harrison, T. S. (2012): Immunotherapy for fungal infections. Current Opinion in Microbiology, 15(4):434-439. doi:10.1016/j.mib.2012.06.001

Arsić Arsenijević, V., Otašević, S., Janić, D., Minić, P., Matijašević, J., Medić, D., Savić, I., Delić, S., Laban, N. S.,Vasiljević, Z. és Hadnadjev, M. (2017): Candida bloodstream infections in Serbia: First multicentre report of a national prospective observational survey in intensive care units. Mycoses, 61(2):70-78. doi:10.1111/myc.12700

Asadzadeh, M., Ahmad, S., Hagen, F., Meis, J. F., Al-Sweih, N. és Khan, Z. (2015): Simple, Low-Cost Detection of Candida parapsilosis Complex Isolates and Molecular Fingerprinting of Candida orthopsilosis Strains in Kuwait by ITS Region Sequencing and Amplified Fragment Length Polymorphism Analysis. PLOS ONE, 10(11):e0142880. doi:10.1371/journal.pone.0142880

Ashford, B. (1928): Certain conditions of the gastrointestinal tract in Puerto Rico and their relation to tropical sprue. The American Journal of Tropical Medicine and Hygiene, 8:507-538.

Ásmundsdóttir, L. R., Erlendsdóttir, H., Haraldsson, G., Guo, H., Xu, J. és Gottfredsson, M. (2008): Molecular Epidemiology of Candidemia: Evidence of Clusters of Smoldering Nosocomial Infections. Clinical Infectious Diseases, 47(2):e17-e24. doi:10.1086/589298 
Bahri, R., Curt, S., Saidane-Mosbahi, D. és Rouabhia, M. (2010): Normal Human Gingival Epithelial Cells Sense $C$. parapsilosis by Toll-Like Receptors and Module Its Pathogenesis through Antimicrobial Peptides and Proinflammatory Cytokines. Mediators of Inflammation, 2010:940383. doi:10.1155/2010/940383

Bajtai, Zs. és Sármay, G. (2006): Mononukleáris sejtek izolálása. In: Erdei, A. (szerk.): Immunológiai módszerek. Medicina, Budapest, 161-203.

Barton, R. (2018): Serology of fungal disease. In: Kibbler, C. C., Barton, R., Gow, N. A. R., Howell, S., MacCallum, D. M. és Manuel, R. J. (szerk.): Oxford textbook of medical mycology. Oxford University Press, New York, 307-312. doi:10.1093/med/9780198755388.003.0042

Berta, B. (2014): Candida parapsilosis sensu lato fajkomplex interakciója egér csontvelőből származó makrofágokkal. BA/BSc szakdolgozat, Szegedi Tudományegyetem.

Beszedics, Gy., Vágvölgyi, Cs., Kocsubé, S. és Papp, T. (2008): PCR-alapú diagnosztikai eljárás klinikailag fontos Candida fajok kimutatására. Szabadalom: M.Sz.H. P0800725.

Bi, L., Gojestani, S., Wu, W., Hsu, Y.-M. S., Zhu, J., Ariizumi, K. és Lin, X. (2010): CARD9 Mediates Dectin-2-induced IKBa Kinase Ubiquitination Leading to Activation of NF-kB in Response to Stimulation by the Hyphal Form of Candida albicans. Journal of Biological Chemistry, 285(34):25969-25977. doi:10.1074/jbc.m110.131300

Bisgaard, L. S., Mogensen, C. K., Rosendahl, A., Cucak, H., Nielsen, L. B., Rasmussen, S. E. és Pedersen, T. X. (2016): Bone marrow-derived and peritoneal macrophages have different inflammatory response to oxLDL and M1/M2 marker expression - implications for atherosclerosis research. Scientific Reports, 6:35234. doi:10.1038/srep35234

Bongomin, F., Gago, S., Oladele, R. és Denning, D. (2017): Global and Multi-National Prevalence of Fungal Diseases-Estimate Precision. Journal of Fungi, 3(4):57. doi:10.3390/jof3040057

Bourgeois, C., Majer, O., Frohner, I. és Kuchler, K. (2009): In Vitro Systems for Studying the Interaction of Fungal Pathogens with Primary Cells from the Mammalian Innate Immune System. Methods in Molecular Biology, 470:125-139. doi:10.1007/978-1-59745-204-5_11

Bourgeois, C., Majer, O., Frohner, I. E., Lesiak-Markowicz, I., Hildering, K-S., Glaser, W., Stockinger, S., Decker, T., Akira, S., Müller, M. és Kuchler, K. (2011): Conventional Dendritic Cells Mount a Type I IFN Response against Candida spp. Requiring Novel Phagosomal TLR7-Mediated IFN-Signaling. The Journal of Immunology, 186(5):3104-3112. doi:10.4049/jimmunol.1002599

Brown, A. J. P., Brown, G. D., Netea, M. G. és Gow, N. A. R. (2014): Metabolism impacts upon Candida immunogenicity and pathogenicity at multiple levels. Trends in Microbiology, 22(11):614-622. doi:10.1016/j.tim.2014.07.001

Brown, G. D. (2011): Innate Antifungal Immunity: The Key Role of Phagocytes. Annual Review of Immunology, 29(1): 1-21. doi:10.1146/annurev-immunol-030409-101229

Brown, G. D., Denning, D. W., Gow, N. A. R., Levitz, S. M., Netea, M. G. és White, T. C. (2012): Hidden Killers: Human Fungal Infections. Science Translational Medicine, 4(165):165rv13-165rv13. doi:10.1126/scitranslmed.3004404

Brown, G. D. és Gordon, S. (2005). Immune recognition of fungal $\beta$-glucans. Cellular Microbiology, 7(4):471-479. doi:10.1111/j.1462-5822.2005.00505.x

Butler, G., Rasmussen, D. M., Lin, F., M., Santos, S. A. M., Sakthikumar, S., Munro, C. A., Rheinbay, E., Grabherr, M., Forche, A., Reedy, J. L., Agrafioti, I., Arnaud, M. B., Bates, S., Brown, A. J. P., Brunke, S., Costanzo, M. C., Fitzpatric, D. A., de Groot, P. W. J., Harris, D., Hoyer, L. L., Hube, B., Klis, F. M., Kodira, C., Lennard, N., Logue, M. E., Martin, R., Neiman, A. M., Nikolaou, E., Quail, M. A., Quinn, J., Santos, M. C., Schmitzberger F. F., Sherlock, G., Shah, P., Silverstein, K. A. T., Skrzypek, M. S., Soll, D., Staggs, R., Stansfied, I., Stumpf, M. P. H., Sudbery, P. E., Srikantha, T., Zeng, Q., Berman, J., Berriman, M., Heitman, J., Gow, N. A. R., Lorenz, M. C., Birren, B. W., Kellis, M. és Cuomo, C. A. (2009): Evolution 
of pathogenicity and sexual reproduction in eight Candida genomes. Nature, 4;459(7247):657-62. doi: 10.1038/nature08064

Byrd, A. L., Belkaid, Y. és Segre, J. A. (2018): The human skin microbiome. Natue Reviews Microbiology, 16(3):143-155. doi:10.1038/nrmicro.2017.157

Carvalho, A., Duarte-Oliveira, C., Gonçalves, S. M., Campos, A., Lacerda, J. F. és Cunha, C. (2017): Fungal Vaccines and Immunotherapeutics: Current Concepts and Future Challenges. Current Fungal Infection Reports, 11(1):16-24. doi:10.1007/s12281-017-0272-y

Carvalho, A., De Luca, A., Bozza, S., Cunha, C., D’Angelo, C., Moretti, S., Perruccio, K., lannitti, R. G., Fallarino, F., Pierini, A., Latgé, J-P., Velardi, A., Aversa, F. és Romani, L. (2011): TLR3 essentially promotes protective class I-restricted memory CD8+ T-cell responses to Aspergillus fumigatus in hematopoietic transplanted patients. Blood, 119(4):967-977. doi:10.1182/blood-2011-06-362582

Casadevall, A. és Pirofski, L. (2001). Adjunctive Immune Therapy for Fungal Infections. Clinical Infectious Diseases, 33(7):1048-1056. doi:10.1086/322710

Chakraborty, T., Thuer, E., Heijink, M., Tóth, R., Bodai, L., Vágvölgyi, Cs., Gierad, M., Gabaldón, T. és Gácser, A. (2018): Eicosanoid biosynthesis influences the virulence of Candida parapsilosis. Virulence, 9(1):1019-1035. doi:10.1080/21505594.2018.1475797

Chan, G. F., Gan, H. M., Ling, H. L. és Rashid, N. A. A. (2012): Genome Sequence of Pichia kudriavzevii M12, a Potential Producer of Bioethanol and Phytase. Eukaryotic Cell, 11(10): 1300-1301. doi:10.1128/ec.00229-12

Chaudhary, A., Fresquez, T. M. és Naranjo, M. J. (2007): Tyrosine kinase Syk associates with tolllike receptor 4 and regulates signaling in human monocytic cells. Immunology and Cell Biology, 85(3):249-256. doi:10.1038/sj.icb7100030

Chen, S. M., Shen, H., Zhang, T., Huang, X., Liu, X. Q., Guo, S. Y., Zhao, J. J., Wang, C. F., Yan, L., Xu, G. T., Jiang, Y. Y. és An, M. M. (2017): Dectin-1 plays an important role in host defense against systemic Candida glabrata infection. Virulence, 8(8):1643-1656. doi:10.1080/21505594.2017.1346756

Cheng, A. M., Rowley, B., Pao, W., Hayday, A., Bolen, J. B. és Pawson, T. (1995): Syk tyrosine kinase required for mouse viability and B-cell development. Nature, 378(6554):303-306. doi:10.1038/378303a0

Cheng, S-C., Joosten, L. A. B., Kullberg, B-J. és Netea, M. G. (2012): Interplay between Candida albicans and the Mammalian Innate Host Defense. Infection and Immunity, 80(4):1304-1313. doi:10.1128/iai.06146-11

Cohen, N. R., Tatituri, R. V. V., Rivera, A., Watts, G. F. M., Kim, E. Y., Chiba, A., Fuchs, B. B., Mylonakis, E., Besra, G. S., Levitz, S. M., Brigl, M. és Brenner, M. B. (2011): Innate Recognition of Cell Wall $\beta$-Glucans Drives Invariant Natural Killer T Cell Responses against Fungi. Cell Host \& Microbe, 10(5):437-450. doi:10.1016/j.chom.2011.09.011

Colonna, M. (2007): All roads lead to CARD9. Nature Immunology, 8(6):554-555. doi:10.1038/ni0607-554

Cooper, C. R. (2011): Yeasts Pathogenic to Humans. In:, C. P. Kurtzman, C. P.,Fell, J. W. és Boekhout, T. (szerk.): The Yeasts: A Taxonomic Study, Elsevier, Amsterdam, 9-19. doi:10.1016/b978-0-444-521491.00002-1

Csonka, K. (2016): A Candida parapsilosis in vivo fertőzés jellemzése: sejtfal N-mannoziláció szerepe a virulenciában. Doktori értekezés. Szegedi Tudományegyetem.

Dagher, Z., Xu, S., Negoro, P. E., Khan, N. S., Feldman, M. B., Reedy, J. L., Tam, J. M., Sykes, D. B. és Mansour, M. K. (2018): Fluorescent Tracking of Yeast Division Clarifies the Essential Role of Spleen Tyrosine Kinase in the Intracellular Control of Candida glabrata in Macrophages. Frontiers in Immunology, 9:1058. doi:10.3389/fimmu.2018.01058 
Dambuza, I. M. és Brown, G. D. (2015): C-type lectins in immunity: recent developments. Current Opinion in Immunology, 32:21-27. doi:10.1016/j.coi.2014.12.002

Dambuza, I., Levitz, S., Netea, M. G. és Brown, G. (2017): Fungal Recognition and Host Defense Mechanisms. In Heitman, J., Howlett, B., Crous, P., Stukenbrock, E., James, T. és Gow, N. (szerk.): The Fungal Kingdom. ASM Press, Washington, DC, 887-902. doi:10.1128/microbiolspec.FUNK-0050-2016

Dambuza, I. M., Wagener, J., Brown, D. G. és Gow., N. A. R. (2018): Immunology of fungal disease. In: In: Kibbler, C. C., Barton, R., Gow, N. A. R., Howell, S., MacCallum, D. M. és Manuel, R. J. (szerk.): Oxford textbook of medical mycology. Oxford University Press, New York, 62-70. doi:10.1093/med/9780198755388.003.0009

Daniel, H-M., Lachance, M-A. és Kurtzman, C. P. (2014): On the reclassification of species assigned to Candida and other anamorphic ascomycetous yeast genera based on phylogenetic circumscription. Antonie van Leeuwenhoek, 106(1):67-84. doi:10.1007/s10482-014-0170-z

De Filippo, K., Henderson, R. B., Laschinger, M. és Hogg, N. (2008): Neutrophil Chemokines KC and Macrophage-Inflammatory Protein-2 Are Newly Synthesized by Tissue Macrophages Using Distinct TLR Signaling Pathways. The Journal of Immunology, 180(6):4308-4315. doi:10.4049/jimmunol.180.6.4308

De Sousa, M. da G. T., Belda, W., Spina, R., Lota, P. R., Valente, N. S., Brown, G. D., Criado, P. R. és Benard, G. (2014): Topical Application of Imiquimod as a Treatment for Chromoblastomycosis. Clinical Infectious Diseases, 58(12):1734-1737. doi:10.1093/cid/ciu168

Deng, Z., Ma, S., Zhou, H., Zang, A., Fang, Y., Li, T., Shi, H., Liu, M., Du, M., Taylor, P. R., Zhu, H. H., Chen, J., Meng, G., Li, F., Chen, C., Zhang, Y., Jia, X-M., Lin, X., Zhang, X., Pearlman, E., Li, X., Feng, G-S. és Xiao, H. (2015): Tyrosine phosphatase SHP-2 mediates C-type lectin receptor-induced activation of the kinase Syk and anti-fungal TH17 responses. Nature Immunology, 16(6):642-652. doi:10.1038/ni.3155

Dennehy, K. M., Ferwerda, G. , Faro-Trindade, I., Pyż, E., Willment, J. A., Taylor, P. R., Kerrigan, A., Tsoni, S. V., Gordon, S., Meyer-Wentrup, F., Adema, G. J., Kullberg, B., Schweighoffer, E., Tybulewicz, V., Mora-Montes, H. M., Gow, N. A., Williams, D. L., Netea, M. G. és Brown, G. D. (2008): Syk kinase is required for collaborative cytokine production induced through Dectin-1 and Toll-like receptors. European Journal of Immunology, 38(2):500-506. doi:10.1002/eji.200737741

Dismukes, W.E., Pappas, P. G. és Sobel, J. D. (szerk.) (2003): Clinical Mycology. Oxford University Press, New York.

Dockrell, D. H., Mcgrath, E. E., Whyte, M. K. B. és Sabroe, A. I. (2007): Chapter 3, The Neutrophil. In: Brown., G. D. és Netea, M. G. (szerk.): Immunology of fungal infections. Springer, Dordrecht, 51-74.

Dóczi, I., Dósa, E., Hajdú, E. és Nagy, E. (2002): Aetiology and antifungal susceptibility of yeast bloodstream infections in a Hungarian university hospital between 1996 and 2000. Journal of Medical Microbiology, 51:677-681. doi:10.1099/0022-1317-51-8-677

Drewniak, A., Gazendam, R. P., Tool, A. T. J., van Houdt, M., Jansen, M. H., van Hamme, J. L., van Leeuwen, E. M. M., Roos, D., Scalais, E., de Beaufort, C., Janssen, H., van den Berg, T. K. és Kuijpers, T. W. (2013): Invasive fungal infection and impaired neutrophil killing in human CARD9 deficiency. Blood, 121(13):2385-2392. doi:10.1182/blood-2012-08-450551

Drummond, R. A., Collar, A. L., Swamydas, M., Rodriguez, C. A., Lim, J. K., Mendez, L. M., Fink, D. L., Hsu, A. P., Zhai, B., Karauzum, H., Mikelis, C. M., Rose, S. R., Ferre, E. M. N., Yockey, L., Lemberg, K., Kuehn, H. S., Rosenzweig, S. D., Lin, X., Chittiboina, P., Datta, S. K., Belhorn, T. H., Weimer, E. T., Hernandez, M. L., Hohl, T. M., Kuhns, D. B. és Lionakis, M. S. (2015): CARD9-Dependent Neutrophil Recruitment Protects against Fungal Invasion of the Central Nervous System. PLOS Pathogens, 11(12):e1005293. doi:10.1371/journal.ppat.1005293

Drummond, R. A., Franco, L. M. és Lionakis, M. S. (2018): Human CARD9: A Critical Molecule of Fungal Immune Surveillance. Frontiers in Immunology, 9:1836. doi:10.3389/fimmu.2018.01836 
Drummond, R. A., Gaffen, S. L., Hise, A. G. és Brown, G. D. (2014): Innate Defense against Fungal Pathogens. Cold Spring Harbor Perspectives in Medicine, 5(6):a019620-a019620. doi:10.1101/cshperspect.a019620

Drummond, R. A., Saijo, S., Iwakura, Y. és Brown, G. D. (2011): The role of Syk/CARD9 coupled Ctype lectins in antifungal immunity. European Journal of Immunology, 41(2):276-281. doi:10.1002/eji.201041252

Duan, Z., Chen, X., Du, L., Liu, C., Zeng, R., Chen, Q. és Li, M. (2017): Inflammation Induced by Candida parapsilosis in THP-1 Cells and Human Peripheral Blood Mononuclear Cells (PBMCs). Mycopathologia, 182(11-12):1015-1023. doi:10.1007/s11046-017-0187-8

Dujon, B. (2010): Yeast evolutionary genomics. Nature Reviews Genetics, 11(7):512-524. doi:10.1038/nrg2811

Dunn, J. L., Buck, J. D. és Spotte, S. (1982): Candidiasis in captive cetaceans. Journal of The American Veterinary Medical Association, 181:1316-1321.

Ericsson, J., Chryssanthou, E., Klingspor, L., Johansson, A. G., Ljungman, P., Svensson, E. és Sjölin, J. (2012): Candidaemia in Sweden: a nationwide prospective observational survey. Clinical Microbiology and Infection, 19(4):E218-E221. doi:10.1111/1469-0691.12111

El-Khoury, M., Ligot, R., Mahoney, S., Stack, C. M., Perrone, G. G. és Morton, C. O. (2017: The in vitro effects of interferon-gamma, alone or in combination with amphotericin $\mathrm{B}$, tested against the pathogenic fungi Candida albicans and Aspergillus fumigatus. BMC Research Notes, 10:364. doi:10.1186/s13104-017-2696-4

Fitzpatrick, D. A., Logue, M. E., Stajich, J. E. és Butler, G. (2006): A fungal phylogeny based on 42 complete genomes derived from supertree and combined gene analysis. BMC Evolutionary Biology, 6(1):99. doi:10.1186/1471-2148-6-99

Galluzzi, L., Chan, T. A., Kroemer, G., Wolchok, J. D. és López-Soto, A. (2018): The hallmarks of successful anticancer immunotherapy. Science Translational Medicine, 10(459):eaat7807. doi:10.1126/scitranslmed.aat7807

Gantner, B. N., Simmons, R. M., Canavera, S. J., Akira, S. és Underhill, D. M. (2003): Collaborative Induction of Inflammatory Responses by Dectin-1 and Toll-like Receptor 2. The Journal of Experimental Medicine, 197(9):1107-1117. doi:10.1084/jem.20021787

Gantner, B. N., Simmons, R. M. és Underhill, D. M. (2005): Dectin-1 mediates macrophage recognition of Candida albicans yeast but not filaments. The EMBO Journal, 24(6):1277-1286. doi:10.1038/sj.emboj.7600594

Garlanda, C., Hirsch, E., Bozza, S., Salustri, A., De Acetis, M., Nota, R., Maccagnok, A., Riva, F., Bottazzi, B., Peri, G., Doni, A.,Vago, L., Botto, M., Santisq, R. D., Carminatiq, P., Siracusak, G., Altruda, F., Vecchi, A., Romani, L. és Mantovani, A. (2002): Non-redundant role of the long pentraxin PTX3 in anti-fungal innate immune response. Nature, 420(6912):182-186. doi:10.1038/nature01195

Gazendam, R. P., van de Geer, A., Roos, D., van den Berg, T. K. és Kuijpers, T. W. (2016): How neutrophils kill fungi. Immunological Reviews, 273(1):299-311. doi:10.1111/imr.12454

Gazendam, R. P., van Hamme, J. L., Tool, A. T. J., van Houdt, M., Verkuijlen, P. J. J. H., Herbst, M., Liese, J. G., van de Veerdonk, F. L., Roos, D., van den Berg, T. K. és Kuijpers, T. W. (2014): Two independent killing mechanisms of Candida albicans by human neutrophils: evidence from innate immunity defects. Blood, 124(4):590-597. doi:10.1182/blood-2014-01-551473

Gácser, A. (2015): Adhesins in Candida parapsilosis: Understudied players in virulence. Virulence, 7(2):65-67. doi:10.1080/21505594.2015.1135288 
Gácser, A., Salomon, S. és Schafer, W. (2005): Direct transformation of a clinical isolate of Candida parapsilosis using a dominant selection marker. FEMS Microbiology Letters, 245(1):117-121. doi:10.1016/j.femsle.2005.02.035

Gácser, A., Trofa, D., Schäfer, W. és Nosanchuk, J. D. (2007): Targeted gene deletion in Candida parapsilosis demonstrates the role of secreted lipase in virulence. The Journal of Clinical Investigation, 117(10):3049-3058. doi: 10.1172/JCl32294

Ghosn, E. E. B., Cassado, A. A., Govoni, G. R., Fukuhara, T., Yang, Y., Monack, D. M., Bortoluci, K. R., Almeida, S. R., Herzenberg, L. A. és Herzenberg, L. A. (2010): Two physically, functionally, and developmentally distinct peritoneal macrophage subsets. Proceedings of the National Academy of Sciences, 107(6):2568-2573. doi:10.1073/pnas.0915000107

Gillum, A. M., Tsay, E. Y. és Kirsch, D. R. (1984): Isolation of the Candida albicans gene for orotidine5'-phosphate decarboxylase by complementation of S. cerevisiae ura3 and E. coli pyrF mutations. Molecular Genetics and Genomics, 198(1):179-182. doi:10.1007/bf00328721

Glocker, E-O., Hennigs, A., Nabavi, M., Schäffer, A. A., Woellner, C., Salzer, U., Pfeifer, D., Veelken, H., Warnatz, K., Tahami, F., Jamal, S., Manguiat, A., Rezaei, N., Amirzargar, A. A., Plebani, A., Hannesschläger, N., Gross, O., Ruland, J. és Grimbacher, B. (2009): A Homozygous CARD9 Mutation in a Family with Susceptibility to Fungal Infections. New England Journal of Medicine, 361(18):1727-1735. doi:10.1056/nejmoa0810719

Goodridge, H. S., Shimada, T., Wolf, A. J., Hsu, Y.-M. S., Becker, C. A., Lin, X. és Underhill, D. M. (2009): Differential Use of CARD9 by Dectin-1 in Macrophages and Dendritic Cells. The Journal of Immunology, 182(2):1146-1154. doi:10.4049/jimmunol.182.2.1146

Goto, M., Katayama, K-I., Shirakawa, F. és Tanaka, I. (1999): Involvement of NF-kB p50/p65 heterodimer in activation of the human pro-interleukin-1 $\beta$ gene at two subregions of the upstream enhancer element. Cytokine, 11(1):16-28. doi:10.1006/cyto.1998.0390

Gow, N. A. és Netea, M. G. (2016): Medical mycology and fungal immunology: new research perspectives addressing a major world health challenge. Philosophical Transactions of the Royal Society B: Biological Sciences, 371:20150462. doi:10.1098/rstb.2015.0462

Gow, N. A. R., Netea, M. G., Munro, C. A., Ferwerda, G., Bates, S., Mora-Montes, H. M., Walker, L., Jansen, T., Jacobs, L., Tsoni, V., Brown, G. D., Odds, F. C., Van der Meer, J. W. M., Brown, A. J. P. és Kullberg, B. J. (2007): Immune Recognition of Candida albicans $\beta$-glucan by Dectin-1. The Journal of Infectious Diseases, 196(10):1565-1571. doi:10.1086/523110

Gow, N., Latge, J. és Munro, C. (2017): The Fungal Cell Wall: Structure, Biosynthesis, and Function. In Heitman, J., Howlett, B., Crous, P., Stukenbrock, E., James, T. és Gow, N. (szerk.): The Fungal Kingdom. ASM Press, Washington, DC, 267-292. doi:10.1128/microbiolspec.FUNK-0035-2016

Goyal, S., Castrillón-Betancur, J. C., Klaile, E. és Slevogt, H. (2018): The Interaction of Human Pathogenic Fungi With C-Type Lectin Receptors. Frontiers in Immunology, 9:1261. doi:10.3389/fimmu.2018.01261

Gringhuis, S. I., den Dunnen, J., Litjens, M., van der Vlist, M., Wevers, B., Bruijns, S. C. M. és Geijtenbeek, T. B. H. (2009): Dectin-1 directs T helper cell differentiation by controlling noncanonical NF-KB activation through Raf-1 and Syk. Nature Immunology, 10(2):203-213. doi:10.1038/ni.1692

Gringhuis, S. I., Kaptein, T. M., Wevers, B. A., Theelen, B., van der Vlist, M., Boekhout, T. és Geijtenbeek, T. B. H. (2012): Dectin-1 is an extracellular pathogen sensor for the induction and processing of IL-1 $\beta$ via a noncanonical caspase-8 inflammasome. Nature Immunology, 13(3):246-254. doi:10.1038/ni.2222

Gross, O., Gewies, A., Finger, K., Schäfer, M., Sparwasser, T., Peschel, C., Förster, I. és Ruland, J. (2006): Card9 controls a non-TLR signalling pathway for innate anti-fungal immunity. Nature, 442(7103):651-656. doi:10.1038/nature04926 
Gross, O., Poeck, H., Bscheider, M., Dostert, C., Hannesschläger, N., Endres, S., Hartmann, G., Tardivel, A., Schweighoffer. E., Tybulewicz, V., Mocsai, A., Tschopp, J. és Ruland, J. (2009): Syk kinase signalling couples to the Nlrp3 inflammasome for anti-fungal host defence. Nature, 459(7245):433436. doi:10.1038/nature07965

Grózer, Zs., Tóth, A., Tóth, R., Kecskeméti, A., Vágvölgyi, C., Nosanchuk, J. D., Szekeres, A. és Gácser, A. (2015): Candida parapsilosis produces prostaglandins from exogenous arachidonic acid and OLE2 is not required for their synthesis. Virulence, 6(1):85-92. doi:10.4161/21505594.2014.988097

Guarner, J. és Brandt, M. E. (2011): Histopathologic Diagnosis of Fungal Infections in the $21^{\text {st }}$ Century. Clinical Microbiology Reviews, 24(2):247-280. doi:10.1128/cmr.00053-10

Halmy, K. (1997): Microspóriás fertőzések Hajdú-Bihar megyében. Orvosi Hetilap, 138(21):13291332.

Hara, H. és Saito, T. (2009): CARD9 versus CARMA1 in innate and adaptive immunity. Trends in Immunology, 30(5):234-242. doi:10.1016/j.it.2009.03.002

Hara, H., Ishihara, C., Takeuchi, A., Imanishi, T., Xue, L., Morris, S. W., Inui, M., Takai, T., Shibuya, A., Saijo, S., Iwakura, Y., Ohno, N., Koseki, H., Yoshida, H., Penninger J. M. és Saito, T. (2007): The adaptor protein CARD9 is essential for the activation of myeloid cells through ITAM-associated and Toll-like receptors. Nature Immunology, 8(6):619-629. doi:10.1038/ni1466

Heinsbroek, S. E. M. és Gordon, S. (2007): Chapter 1, Macrophages. In: Brown., G. D. és Netea, M. G. (szerk.): Immunology of fungal infections. Springer, Dordrecht, 3-25.

Herre, J., Marshall, A. S., Caron, E., Edwards, A. D., Williams, D. L., Schweighoffer, E., Tybulewicz, V., Sousa, C. R., Gordon, S. és Brown, G. D. (2004): Dectin-1 uses novel mechanisms for yeast phagocytosis in macrophages. Blood, 104(13):4038-4045. doi:10.1182/blood-2004-03-1140

Heyl, K. A., Klassert, T. E., Heinrich, A., Muller, M. M., Klaile, E., Dienemann, H., Grünewald, C., Bals, R., Singer B. B. és Slevogt, H. (2014): Dectin-1 Is Expressed in Human Lung and Mediates the Proinflammatory Immune Response to Nontypeable Haemophilus influenzae. mBio, 5(5): e01492-14. doi:10.1128/mbio.01492-14

Hof, H. (2009): Mycoses in the elderly. European Journal of Clinical Microbiology and Infectious Diseases, 29(1):5-13. doi:10.1007/s10096-009-0822-5

Holland, L. M., Schröder, M. S., Turner, S. A., Taff, H., Andes, D., Grózer, Zs., Gácser, A., Ames, L., Haynes, K., Higgins, D. G. és Butler, G. (2014): Comparative Phenotypic Analysis of the Major Fungal Pathogens Candida parapsilosis and Candida albicans. PLoS Pathogens, 10(9):e1004365. doi:10.1371/journal.ppat.1004365

Horváth, P., Nosanchuk, J. D., Hamari, Z., Vágvölgyi, Cs. és Gácser, A. (2012): The Identification of Gene Duplication and the Role of Secreted Aspartyl Proteinase 1 in Candida parapsilosis Virulence. The Journal of Infectious Diseases, 205(6):923-933. doi:10.1093/infdis/jir873

Höfs, S., Mogavero, S. és Hube, B. (2016): Interaction of Candida albicans with host cells: virulence factors, host defense, escape strategies, and the microbiota. Journal of Microbiology, 54(3):149-169. doi:10.1007/s12275-016-5514-0

Hsu, Y-M. S., Zhang, Y., You, Y., Wang, D., Li, H., Duramad, O., Qin, X-F., Dong, C. és Lin, X. (2006): The adaptor protein CARD9 is required for innate immune responses to intracellular pathogens. Nature Immunology, 8(2):198-205. doi:10.1038/ni1426

Hu, X-P., Wang, R-Y., Wang, X., Cao, Y-H., Chen, Y-Q., Zhao, H-Z., Wu, J-Q., Weng, X-H., Gao, X-H., Sun, R-H. és Zhu, L-P. (2015): Dectin-2 polymorphism associated with pulmonary cryptococcosis in HIVuninfected Chinese patients. Medical Mycology, 53(8):810-816. doi:10.1093/mmy/myv043

Ifrim, D. C., Bain, J. M., Reid, D. M., Oosting, M., Verschueren, I., Gow, N. A. R., van Krieken, J. H., Brown, G. D., Kullberg, B-J., Joosten, L. A. B., van der Meer, J. W. M., Koentgen, F., Erwig, L. P., Quintin, 
J. és Netea, M. G. (2013): Role of Dectin-2 for Host Defense against Systemic Infection with Candida glabrata. Infection and Immunity, 82(3):1064-1073. doi:10.1128/iai.01189-13

Irinyi, L., Serena, C., Garcia-Hermoso, D., Arabatzis, M., Desnos-Ollivier, M., Vu, D., Cardinali, G., Arthur, I., Normand, A-C., Giraldo, A., Cassia da Cunha, K., Sandoval-Denis, M., Hendrickx, M., Nishikaku, A. S., de Azevedo Melo, A. S., Merseguel, K. B., Khan, A., Rocha, J. A. P., Sampaio, P., da Silva Briones, M. R., e Ferreira, R. C., de Medeiros Muniz, M., Castañón-Olivares, L. R., Estrada-Barcenas, D., Cassagne, C., Mary, C., Duan,S. Y., Kong, F., Sun, A. Y., Zeng, X., Zhao, Z., Gantois, N., Botterel, F., Robbertse, B., Schoch, C., Gams, W., Ellis, D., Halliday, C., Chen, S., Sorrell, T. C., Piarroux, R., Colombo, A. L., Pais, C., de Hoog, S., Zancopé-Oliveira, R. M., Taylor, M. L., Toriello, C., de Almeida Soares, C. M., Delhaes, L., Stubbe, D., Dromer, F., Ranque, S., Guarro, J., Cano-Lira, J. F., Robert, V., Velegraki, A. és Meyer, W. (2015): International Society of Human and Animal Mycology (ISHAM)-ITS reference DNA barcoding database-the quality controlled standard tool for routine identification of human and animal pathogenic fungi. Medical Mycology, 53(4):313-337. doi:10.1093/mmy/myv008

Jakus, Z., Simon, E., Balázs, B. és Mócsai, A. (2010): Genetic deficiency of Syk protects mice from autoantibody-induced arthritis. Arthritis \& Rheumatism, 62(7):1899-1910. doi:10.1002/art.27438

Jeffery-Smith, A., Taori, S. K., Schelenz, S., Jeffery, K., Johnson, E. M., Borman, A., Candida auris Incident Management Team, Manuel, R. és Brown, C. S. (2017): Candida auris: a Review of the Literature. Clinical Microbiology Reviews, 31(1): e00029-17. doi:10.1128/cmr.00029-17

Jia, X-M., Tang, B., Zhu, L-L., Liu, Y-H., Zhao, X-Q., Gorjestani, Hsu, Y-M. S., Yang, L., Guan, J-H., GuoTong Xu, G-T. és Lin, X. (2014): CARD9 mediates Dectin-1-induced ERK activation by linking Ras-GRF1 to H-Ras for antifungal immunity. The Journal of Experimental Medicine, 211(11):2307-2321. doi:10.1084/jem.20132349

Jones, T., Federspiel, N. A., Chibana, H., Dungan, J., Kalman, S., Magee, B. B., Newport, G., Thorstenson, Y. R., Agabian, N., Magee, P. T., Davis, R. W. és Scherer, S. (2004): The diploid genome sequence of Candida albicans. Proceedings of the National Academy of Sciences of the United States of America, 101(19):7329-7334. doi:10.1073/pnas.0401648101

Kakeya, H., Yamada, K., Kaneko, Y., Yanagihara, K., Tateda, K., Maesaki, S., Takesue, Y., Tomono, K., Kadota, J-i., Kaku, M., Miyazaki, Y., Kamei, K., Shibuya, K., Niki, Y., Yoshida, M. és Sei, Y. (2018): National Trends in the Distribution of Candida Species Causing Candidemia in Japan from 2003 to 2014. Medical Mycology Journal, 59(1):E19-E22. doi:10.3314/mmj.17-00014

Kasper, L., Seider, K., Gerwien, F., Allert, S., Brunke, S., Schwarzmüller, T., Ames, L., Zubiria-Barrera, C., Mansour, M. K., Becken, U., Barz, D., Vyas, J. M., Reiling, N., Haas, A., Haynes, K., Kuchler, K. és Hube, B. (2014): Identification of Candida glabrata Genes Involved in pH Modulation and Modification of the Phagosomal Environment in Macrophages. PLoS ONE, 9(5):e96015. doi:10.1371/journal.pone.0096015

Katragkou, A., Chatzimoschou, A., Simitsopoulou, M., Dalakiouridou, M., Diza-Mataftsi, E., Tsantali, C. és Roilides, E. (2008): Differential Activities of Newer Antifungal Agents against Candida albicans and Candida parapsilosis Biofilms. Antimicrobial Agents and Chemotherapy, 52(1):357-360. doi:10.1128/aac.00856-07

Kawakita, S. és Van Uden, N. (1965): Occurrence and Population Densities of Yeast Species in the Digestive Tracts of Gulls and Terns. Journal of General Microbiology, 39(1):125-129. doi:10.1099/00221287-39-1-125

Kempf, V. A. J., Mändle, T., Schumacher, U., Schäfer, A. és Autenrieth, I. B. (2005): Rapid detection and identification of pathogens in blood cultures by fluorescence in situ hybridization and flow cytometry. International Journal of Medical Microbiology, 295(1):47-55. doi:10.1016/j.ijmm.2004.12.006 
Kerrigan, A. M. és Brown, G. D. (2010): Syk-coupled C-type lectin receptors that mediate cellular activation via single tyrosine based activation motifs. Immunological Reviews, 234(1):335-352. doi:10.1111/j.0105-2896.2009.00882.x

Ketelut-Carneiro, N., Silva, G. K., Rocha, F. A., Milanezi, C. M., Cavalcanti-Neto, F. F., Zamboni, D. S. és Silva, J. S. (2015): IL-18 Triggered by the NIrp3 Inflammasome Induces Host Innate Resistance in a Pulmonary Model of Fungal Infection. The Journal of Immunology, 194(9):4507-4517. doi:10.4049/jimmunol.1402321

Kim, S-K., Bissati, K. E. és Mamoun, C. B. (2006): Amino acids mediate colony and cell differentiation in the fungal pathogen Candida parapsilosis. Microbiology, 152(10):2885-2894. doi:10.1099/mic.0.29180-0

Kirk, P. M, Cannon, P. F., Minter, D. W. és Stalpers, J. A. (szerk.) (2008): Dictionary of the Fungi, 10. kiadás. CAB International, Wallingford.

Kozik, A., Karkowska-Kuleta, J., Zajac, D., Bochenska, O., Kedracka-Krok, S., Jankowska, U. és Rapala-Kozik, M. (2015): Fibronectin-, vitronectin- and laminin-binding proteins at the cell walls of Candida parapsilosis and Candida tropicalis pathogenic yeasts. BMC Microbiology, 15:197. doi:10.1186/s12866-015-0531-4

Köhler, J. R., Casadevall, A. és Perfect, J. (2014): The Spectrum of Fungi That Infects Humans. Cold Spring Harbor Perspectives in Medicine, 5(1):a019273-a019273. doi:10.1101/cshperspect.a019273

Köhler, J. R., Hube, B., Puccia, R., Casadevall, A. és Perfect, J. (2017): Fungi that Infect Humans. In Heitman, J., Howlett, B., Crous, P., Stukenbrock, E., James, T. és Gow, N. (szerk.): The Fungal Kingdom. ASM Press, Washington, DC, 813-843. doi:10.1128/microbiolspec.FUNK-0014-2016

KÖJÁL 1983 (1985): Mikológiai laboratóriumok. In: A közegészségügyi-járványtani állomások járványügyi osztálya 1983. évi munkájának értékeléséről az 1983. évi jelentések felhasználásával. Az Országos Közegészségügyi Intézet Módszertani Levelei, 14:295-306.

KÖJÁL 1984 (1985): Mikológiai laboratóriumok. In: A közegészségügyi-járványtani állomások járványügyi osztálya 1984. évi munkájának értékeléséről az 1984. évi jelentések felhasználásával. Az Országos Közegészségügyi Intézet Módszertani Levelei, 15:235-245.

Kuhn, D. M., Mukherjee, P. K., Clark, T. A., Pujol, C., Chandra, J., Hajjeh, A., Warnock, D. W., Soll, D. R. és Ghannoum, M. A. (2004): Candida parapsilosis characterization in an outbreak setting. Emerging Infectious Diseases, 10(6):1074-1081. doi:10.3201/eid1006.030873

Kullberg, B. J. (2007): Chapter 20, Cytokine Treatment Of Fungal Infections. In: Brown., G. D. és Netea, M. G. (szerk.): Immunology of fungal infections. Springer, Dordrecht, 445-463.

Kurtzman C. P. és Fell J.W. (2006): Yeast Systematics and Phylogeny - Implications of Molecular Identification Methods for Studies in Ecology. In: Péter G. és Rosa C. (szerk.): Biodiversity and Ecophysiology of Yeasts. The Yeast Handbook. Springer, Berlin, Heidelberg, 11-30. doi:10.1007/3-54030985-3_2

Laffey, S. F. és Butler, G. (2005): Phenotype switching affects biofilm formation by Candida parapsilosis. Microbiology, 151(4):1073-81. doi:10.1099/mic.0.27739-0

Lang, R., Schoenen, H. és Desel, C. (2011): Targeting Syk-Card9-activating C-type lectin receptors by vaccine adjuvants: Findings, implications and open questions. Immunobiology, 216(11):1184-1191. doi:10.1016/j.imbio.2011.06.005

Langeron, M. és Talice, R. V. (1932): Nouvelles méthodes d'étude et essai de classification des champignons levuriformes. Annales de Parasitologie Humaine Comparée, 10:1-80. doi:10.1051/parasite/1932101001

Lanternier, F., Mahdaviani, S. A., Barbati, E., Chaussade, H., Koumar, Y., Levy, R., Denis, B., Brunel, A-S., Martin, S., Loop, M., Peeters, J., de Selys, A., Vanclaire, J., Vermylen, C., Nassogne, M-C., Chatzis, 
O., Liu, L., Migaud, M., Pedergnana, V., Desoubeaux, G., Jouvion, G., Chretien, F., Darazam, I. A., Schaffer, A. A., Netea, M. G., De Bruycker, J. J., Bernard, L., Reynes, J., Amazrine, N., Abel, L, Van der Linden, D., Harrison, T., Picard, C., Lortholary, O., Mansouri, D., Casanova, J-L. és Puel, A. (2015): Inherited CARD9 deficiency in otherwise healthy children and adults with Candida species-induced meningoencephalitis, colitis, or both. Journal of Allergy and Clinical Immunology, 135(6):1558-1568.e2. doi:10.1016/j.jaci.2014.12.1930

Larone, D. H. (1987): Medically important fungi: a guide to identification. 2. kiadás. Elsevier, Wasington, DC.

Lee, D. H. és Kim, H. W. (2014): Innate Immunity Induced by Fungal $\beta$-Glucans via Dectin-1 Signaling Pathway. International Journal of Medicinal Mushrooms, 16(1):1-16. doi:10.1615/IntJMedMushr.v16.i1.10

LeibundGut-Landmann, S., Groß, O., Robinson, M. J., Osorio, F., Slack, E. C., Tsoni, S. V., Schweighoffer, E., Tybulewicz, V., Brown, G. D., Ruland, J. és e Sousa, C. R. (2007): Syk- and CARD9dependent coupling of innate immunity to the induction of T helper cells that produce interleukin 17. Nature Immunology, 8(6): 630-638. doi:10.1038/ni1460

Li, X., Cullere, X., Nishi, H., Saggu, G., Durand, E., Mansour, M. K., Tam, J. M., Song, X., Lin, X.,Vyas, J. M. és Mayadas, T. (2016): PKC- $\delta$ activation in neutrophils promotes fungal clearance. Journal of Leukocyte Biology, 100(3):581-588. doi:10.1189/jlb.4a0915-405r

Lin, D. M., Wu L-C., Rinaldi, M. G. és Lehmann, P. F. (1995): Three distinct genotypes within Candida parapsilosis from clinical sources. Journal of Clinical Microbiology, 33:1815-1821.

Lin, Y-C., Huang, D-Y., Wang, J-S., Lin, Y-L., Hsieh, S-L., Huang, K-C. és Lin, W-W. (2015): Syk is involved in NLRP3 inflammasome-mediated caspase-1 activation through adaptor ASC phosphorylation and enhanced oligomerization. Journal of Leukocyte Biology, 97(5):825-835. doi:10.1189/jlb.3hi0814-371rr

Linden, J. R., Kunkel, D., Laforce-Nesbitt, S. S. és Bliss, J. M. (2013): The role of galectin-3 in phagocytosis of Candida albicans and Candida parapsilosis by human neutrophils. Cellular Microbiology, 15(7):1127-1142. doi:10.1111/cmi.12103

Lionakis, M. S. és Netea, M. G. (2013): Candida and Host Determinants of Susceptibility to Invasive Candidiasis. PLoS Pathogens, 9(1):e1003079. doi:10.1371/journal.ppat.1003079

Lionakis, M. S., Iliev, I. D. és Hohl, T. M. (2017): Immunity against fungi. JCl Insight, 2(11):e93156. doi:10.1172/jci.insight.93156

Logue, M. E., Wong, S., Wolfe, K. H. és Butler, G. (2005): A genome sequence survey shows that the pathogenic yeast Candida parapsilosis has a defective MTLa1 allele at its mating type locus. Eukaryotic Cell, 4(6):1009-1017. doi:10.1128/ec.4.6.1009-1017.2005

Ma, T. K-W, McAdoo, S. P. és Tam, F. W-K. (2016): Spleen Tyrosine Kinase: A Crucial Player and Potential Therapeutic Target in Renal Disease. Nephron, 133(4):261-269. doi:10.1159/000446879

Mahanty, S., Greenfield, R. A., Joyce, W. A. és Kincade P. W. (1988): Inoculation candidiasis in a murine model of severe combined immunodeficiency syndrome. Infection and Immunity, 56(12):31623166.

Majeed, M., Caveggion, E., Lowell, C. A. és Berton, G. (2001): Role of Src kinases and Syk in Fcy receptor-mediated phagocytosis and phagosome-lysosome fusion. Journal of Leukocyte Biology, 70:801-811. doi:10.1189/jlb.70.5.801

Majoros, L., Kardos, G., Pócsi, I. és Szabó, B. (2002): Distribution and susceptibility of Candida species isolated in the Medical University of Debrecen. Acta Microbiologica et Immunologica Hungarica, 49(2-3):351-361. doi:10.1556/amicr.49.2002.2-3.25 
Mansour, M. K., Tam, J. M., Khan, N. S., Seward, M., Davids, P. J., Puranam, S., Sokolovska, A., Sykes, D. B., Dagher, Z., Becker, C., Tanne, A., Reedy, J. L., Stuart, L. M. és Vyas, J. M. (2013): Dectin-1 Activation Controls Maturation of $\beta-1,3-$ Glucan-containing Phagosomes. Journal of Biological Chemistry, 288(22):16043-16054. doi:10.1074/jbc.m113.473223

Markham, A. (2018): Fostamatinib: First Global Approval. Drugs, 78(9):959-963. doi:10.1007/s40265-018-0927-1

Marples, M. J. és Somerville, D. A. (1968): The oral and cutaneous distribution of Candida albicans and other yeasts in Rarotonga, Cook Islands. Transactions of the Royal Society of Tropical Medicine and Hygiene, 62(2):256-262. doi:10.1016/0035-9203(68)90166-1

Matthews, R. C., Rigg, G., Hodgetts, S., Carter, T., Chapman, C., Gregory, C., Illidge, C. és Burnie, J. (2003): Preclinical Assessment of the Efficacy of Mycograb, a Human Recombinant Antibody against Fungal HSP90. Antimicrobial Agents and Chemotherapy, 47(7):2208-2216. doi:10.1128/aac.47.7.22082216.2003

Mayer, F. L., Wilson, D. és Hube, B. (2013): Candida albicans pathogenicity mechanisms. Virulence, 4(2):119-128. doi:10.4161/viru.22913

McManus, B. A. és Coleman, D. C. (2014): Molecular epidemiology, phylogeny and evolution of Candida albicans. Infection, Genetics and Evolution, 21:166-178. doi:10.1016/j.meegid.2013.11.008

Meyers, S. P., Ahearn, D. G. és Roth, F. J. (1967): Mycological Investigations of the Black Sea. Bulletin of Marine Science, 17(3):576-596.

Moalli, F., Doni, A., Deban, L., Zelante, T., Zagarella, S., Bottazzi, B., Romani, L., Mantovani, A. és Garlanda, C. (2010): Role of complement and Fc receptors in the protective activity of the long pentraxin PTX3 against Aspergillus fumigatus. Blood, 116(24):5170-5180. doi:10.1182/blood-2009-12258376

Moris, D. V., Melhem, M. S. C., Martins, M. A. és Mendes, R. P. (2008): Oral Candida spp. colonization in human immunodeficiency virus infected individuals. Journal of Venomous Animals and Toxins including Tropical Diseases, 14(2):224-257. doi:10.1590/s1678-91992008000200004

Moyes, D. L., Runglall, M., Murciano, C., Shen, C., Nayar, D., Thavaraj, S., Kohli, A., Islam, A., MoraMontes, H., Stephen J., Challacombe, S. J. és Naglik, J. R. (2010): A Biphasic Innate Immune MAPK Response Discriminates between the Yeast and Hyphal Forms of Candida albicans in Epithelial Cells. Cell Host \& Microbe, 8(3):225-235. doi:10.1016/j.chom.2010.08.002

Moyes, D. L., Wilson, D., Richardson, J. P., Mogavero, S., Tang, S. X., Wernecke, J., Höfs, S., Gratacap, R. L., Robbins, J., Runglall, M., Murciano, C., Blagojevic, M., Thavaraj, S., Förster, T. M., Hebecker, B., Kasper, L., Vizcay, G., Iancu, S. I, Kichik, N., Häder, A., Kurzai, O., Luo, T., Krüger, T., Kniemeyer, O., Cota, E., Bader, O., Wheeler, R. T., Gutsmann, T., Hube, B. és Naglik, J. R. (2016): Candidalysin is a fungal peptide toxin critical for mucosal infection. Nature, 532(7597):64-68. doi:10.1038/nature17625

Mócsai, A., Ruland, J. és Tybulewicz, V. L. J. (2010): The SYK tyrosine kinase: a crucial player in diverse biological functions. Nature Reviews Immunology, 10(6):387-402. doi:10.1038/nri2765

Mukherjee, J., Pirofski, L. A., Scharff, M. D. és Casadevall, A. (1993): Antibody-mediated protection in mice with lethal intracerebral Cryptococcus neoformans infection. Proceedings of the National Academy of Sciences, 90(8):3636-3640. doi:10.1073/pnas.90.8.3636

Nagy, E., Ábrók, M., Bartha, N., Bereczki, L., Juhász, E., Kardos, G., Kristóf, K., Miszti, C. és Urbán, E. (2014): Mátrix-asszisztált lézer deszorpciós, ionizációs, repülési idő mérésén alapuló tömegspektrometria speciális alkalmazása a klinikai mikrobiológiai diagnosztika területén. Orvosi Hetilap, 155(38):1495-1503. doi:10.1556/OH.2014.29985 
Nagy, I., Filkor, K., Németh, T., Hamari, Z., Vágvölgyi, C. és Gácser, A. (2011): In vitro interactions of Candida parapsilosis wild type and lipase deficient mutants with human monocyte derived dendritic cells. BMC Microbiology, 11(1):122. doi:10.1186/1471-2180-11-122

Navarathna, D. H., Roberts, D. D., Munasinghe, J. és Lizak, M. J. (2016): Imaging Candida Infections in the Host. In: Calderone, R. és Cihlar, R. (szerk.): Candida Species: Methods and Protocols, Methods in Molecular Biology. Springer Science+Business Media, New York, 69-78. doi:10.1007/978-1-49393052-4_6

Netea, M. G., Brown, G. D., Kullberg, B. J. és Gow, N. A. R. (2008): An integrated model of the recognition of Candida albicans by the innate immune system. Nature Reviews Microbiology, 6(1):6778. doi:10.1038/nrmicro1815

Netea, M. G., Joosten, L. A. B., van der Meer, J. W. M., Kullberg, B-J. és van de Veerdonk, F. L. (2015): Immune defence against Candida fungal infections. Nature Reviews Immunology, 15(10):630642. doi:10.1038/nri3897

Netea, M. G., Van der Graaf, C. A. A., Vonk, A. G., Verschueren, I., Van der Meer, J. W. M. és Kullberg, B. J. (2002): The Role of Toll-like Receptor (TLR) 2 and TLR4 in the Host Defense against Disseminated Candidiasis. The Journal of Infectious Diseases, 185(10):1483-1489. doi:10.1086/340511

Neumann, A. K. és Jacobson, K. (2010): A Novel Pseudopodial Component of the Dendritic Cell Anti-Fungal Response: The Fungipod. PLoS Pathogens, 6(2):e1000760. doi:10.1371/journal.ppat.1000760

Németh, T., Futosi, K., Sitaru, C., Ruland, J. és Mócsai, A. (2016): Neutrophil-specific deletion of the CARD9 gene expression regulator suppresses autoantibody-induced inflammation in vivo. Nature Communications, 7:11004. doi:10.1038/ncomms11004

Németh, T., Tóth, A., Hamari, Z., Falus, A., Éder, K., Vágvölgyi, Cs., Guimaraes, A. J., Nosanchuk, J. D. és Gácser, A. (2014): Transcriptome profile of the murine macrophage cell response to Candida parapsilosis. Fungal Genetics and Biology, 65:48-56. doi:10.1016/j.fgb.2014.01.006

Németh, T., Tóth, A., Szenzenstein, J., Horváth, P., Nosanchuk, J. D., Grózer, Zs., Tóth, R., Papp, Cs., Hamari, Zs., Vágvölgyi, Cs. és Gácser, A. (2013): Characterization of Virulence Properties in the $C$. parapsilosis Sensu Lato Species. PLoS ONE, 8(7):e68704. doi:10.1371/journal.pone.0068704

Nguyen, L. N., Gácser, A. és Nosanchuk, J. D. (2011): The Stearoyl-Coenzyme A Desaturase 1 Is Essential for Virulence and Membrane Stress in Candida parapsilosis through Unsaturated Fatty Acid Production. Infection and Immunity, 79(1):136-145. doi:10.1128/iai.00753-10

Nguyen, L. N., Trofa, D. és Nosanchuk, J. D. (2009): Fatty Acid Synthase Impacts the Pathobiology of Candida parapsilosis In Vitro and during Mammalian Infection. PLoS ONE, 4(12):e8421. doi:10.1371/journal.pone.0008421

Nosanchuk, J. D., Steenbergen, J. N., Shi, L., Deepe, G. S. Jr. és Casadevall, A. (2003): Antibodies to a cell surface histone-like protein protect against Histoplasma capsulatum. Journal of Clinical Investigation, 112(8):1164-1175. doi:10.1172/JCl19361

Nucci, M., Queiroz-Telles, F., Alvarado-Matute, T., Tiraboschi, I. N., Cortes, J., Zurita, J., GuzmanBlanco, M., Santolaya, M. E., Thompson, L., Sifuentes-Osornio, J., Echevarria, J. I. és Colombo, A . L. (2013): Epidemiology of candidemia in Latin America: a laboratory-based survey. PLoS One, 8:e59373. doi:10.1371/journal.pone.0059373

Núñez-Beltrán, A., López-Romero, E. és Cuéllar-Cruz, M. (2017): Identification of proteins involved in the adhesion of Candida species to different medical devices. Microbial Pathogenesis, 107:293-303. doi:10.1016/j.micpath.2017.04.009

Odds, F. C. (1988): Candida and Candidosis, 2. kiadás. London, Bailliere Tindall. 
Oeser, C., Lamagni, T., Heath, P. T., Sharland, M. és Ladhani, S. (2013): The epidemiology of neonatal and pediatric candidemia in England and Wales, 2000-2009. Pediatric Infectious Disease Journal, 32(1):23-26. doi:10.1097/INF.0b013e318275612e

Ohmura, Y., Matsunaga, K., Motokawa, I., Sakurai, K. és Ando, T. (2001): Protective effects of a protein-bound polysaccharide, PSK, on Candida albicans infection in mice via tumor necrosis factor- $\alpha$ induction. International Immunopharmacology, 1(9-10):1797-1811. doi:10.1016/s15675769(01)00104-7

Ohmura, Y., Matsunaga, K., Motokawa, I., Sakurai, K. és Ando, T. (2003): Protective Effects of a Protein-Bound Polysaccharide, PSK, Against Candida albicans Infection in Syngeneic Tumor-Bearing Mice via Th1 Cell Functions. Cancer Biotherapy and Radiopharmaceuticals, 18(5):769-780. doi:10.1089/108497803770418319

Ono, S. J., Nakamura, T., Miyazaki, D., Ohbayashi, M., Dawson, M. és Toda, M. (2003): Chemokines: Roles in leukocyte development, trafficking, and effector function. Journal of Allergy and Clinical Immunology, 111(6):1185-1199. doi:10.1067/mai.2003.1594

Pammi, M., Holland, L., Butler, G., Gácser, A. és Bliss, J. M. (2013): Candida parapsilosis is a Significant Neonatal Pathogen. The Pediatric Infectious Disease Journal, 32(5):e206-e216. doi:10.1097/inf.0b013e3182863a1c

Papp, Cs., Kocsis, K., Tóth, R., Bodai, L., Willis, J. R., Ksiezopolska, E., Lozoya-Pérez, N.E., Vágvölgyi, Cs., Mora Montes, H., Gabaldón, T., Nosanchuk, J.D. és Gácser, A. (2018): Echinocandin-Induced Microevolution of Candida parapsilosis Influences Virulence and Abiotic Stress Tolerance. mSphere, 3(6):e00547-18. doi:10.1128/msphere.00547-18

Pappas, P. G., Rex, J. H., Sobel, J. D., Filler, S. G., Dismukes, W. E., Walsh, T. J. és Edwards, J. E. (2004): Guidelines for Treatment of Candidiasis. Clinical Infectious Diseases, 38(2):161-189. doi:10.1086/380796

Patin, E. C., Jones, A. V., Thompson, A., Clement, M., Liao, C.-T., Griffiths, J. S., Wallace, L. E., Bryant, C. E., Lang, R., Rosenstiel, P., Humphreys, I. R., Taylor, P. R., Jones, G. W. és Orr, S. J. (2016): IL-27 Induced by Select Candida spp. via TLR7/NOD2 Signaling and IFN- $\beta$ Production Inhibits Fungal Clearance. The Journal of Immunology, 197(1):208-221. doi:10.4049/jimmunol.1501204

Perlin, D. S. (2015): Mechanisms of echinocandin antifungal drug resistance. Annals of the New York Academy of Sciences, 1354(1):1-11. doi:10.1111/nyas.12831

Pfaller, M. A., Diekema, D. J., Gibbs, D. L., Newell, V. A., Ellis, D., Tullio, V., Rodloff, A., Fu, W., Ling, T. A. és a Global Antifungal Surveillance Group (2010): Results from the ARTEMIS DISK Global Antifungal Surveillance Study, 1997 to 2007: a 10.5-Year Analysis of Susceptibilities of Candida Species to Fluconazole and Voriconazole as Determined by CLSI Standardized Disk Diffusion. Journal of Clinical Microbiology, 48(4):1366-1377. doi:10.1128/jcm.02117-09

Pfaller, M. A., Moet, G. J., Messer, S. A., Jones, R. N. és Castanheira, M. (2011): Candida Bloodstream Infections: Comparison of Species Distributions and Antifungal Resistance Patterns in Community-Onset and Nosocomial Isolates in the SENTRY Antimicrobial Surveillance Program, 20082009. Antimicrobial Agents and Chemotherapy, 55(2):561-566. doi:10.1128/aac.01079-10

Poeck, H. és Ruland, J. (2010): SYK kinase signaling and the NLRP3 inflammasome in antifungal immunity. Journal of Molecular Medicine, 88(8):745-752. doi:10.1007/s00109-010-0631-4

Poikonen, E., Lyytikäinen, O., Anttila, V.-J., Koivula, I., Lumio, J., Kotilainen, P., Syrjälä, H. és Ruutu, P. (2010): Secular trend in candidemia and the use of fluconazole in Finland, 2004-2007. BMC Infectious Diseases, 10:312. doi:10.1186/1471-2334-10-312

Pryszcz, L. P., Németh, T., Gácser, A. és Gabaldon, T. (2013): Unexpected genomic variability in clinical and environmental strains of the pathogenic yeast Candida parapsilosis. Genome Biology and Evolution, 5(12):2382-2392. doi:10.1093/gbe/evt185 
Pulcrano, G., Iula, D. V., Vollaro, A., Tucci, A., Cerullo, M., Esposito, M., Rossano, F. és Catania, M. R. (2013): Rapid and reliable MALDI-TOF mass spectrometry identification of Candida non-albicans isolates from bloodstream infections. Journal of Microbiological Methods, 94(3):262-266. doi:10.1016/j.mimet.2013.07.001

Quindós, G. (2014): Epidemiology of candidaemia and invasive candidiasis. A changing face. Revista Iberoamericana de Micología, 31(1):42-48. doi:10.1016/j.riam.2013.10.001

Rafat, Z., Hashemi, S. J., Ahamdikia, K., Ghazvini, R. D. és Bazvandi, F. (2018): Study of Skin and Nail Candida Species as a Normal Flora Based on Age Groups in Healthy Persons in Tehran-Iran (2016): Journal of Medical Mycology, 27(4):501-505. doi:10.1016/j.mycmed.2017.08.007

Ravikumar, S., Win, M. S. és Chai, L. Y. A. (2015): Optimizing Outcomes in Immunocompromised Hosts: Understanding the Role of Immunotherapy in Invasive Fungal Diseases. Frontiers in Microbiology, 6:1322. doi:10.3389/fmicb.2015.01322

Richardson, M. D., Gray, C. A. és Shankland, G. S. (1991): Opsonic effect of C-reactive protein on phagocytosis and intracellular killing of virulent and attenuated strains of Candida albicans by human neutrophils. FEMS Microbiology Letters, 76(6):341-344. doi:10.1111/j.1574-6968.1991.tb04259.x

Richardson, M. és Lass-Flörl, C. (2008): Changing epidemiology of systemic fungal infections. Clinical Microbiology and Infection, 14:5-24. doi:10.1111/j.1469-0691.2008.01978.x

Robinson, M. J., Osorio, F., Rosas, M., Freitas, R. P., Schweighoffer, E., Groß, O., Verbeek, J. S., Ruland, J., Tybulewicz, V., Brown, G. D., Moita, L. F., Taylor, P. R. és e Sousa, C. R. (2009): Dectin-2 is a Syk-coupled pattern recognition receptor crucial for Th17 responses to fungal infection. The Journal of Experimental Medicine, 206(9):2037-2051. doi:10.1084/jem.20082818

Roeder, A., Kirschning, C. J., Schaller, M., Weindl, G., Wagner, H., Korting, H. és Rupec, R. A. (2004): Induction of Nuclear Factor-KB and c-Jun/Activator Protein-1 via Toll-Like Receptor 2 in Macrophages by Antimycotic-Treated Candida albicans. The Journal of Infectious Diseases, 190(7):1318-1326. doi:10.1086/423854

Roemer, T. és Krysan, D. J. (2014): Antifungal Drug Development: Challenges, Unmet Clinical Needs, and New Approaches. Cold Spring Harbor Perspectives in Medicine, 4(5):a019703-a019703. doi:10.1101/cshperspect.a019703

Rogers, N. C., Slack, E. C., Edwards, A. D., Nolte, M. A., Schulz, O., Schweighoffer, E., Williams, D. L., Gordon, S., Tybulewicz, V. L., Brown, G. D. és e Sousa, C. R. (2005): Syk-Dependent Cytokine Induction by Dectin-1 Reveals a Novel Pattern Recognition Pathway for C Type Lectins. Immunity, 22(4):507-517. doi:10.1016/j.immuni.2005.03.004

Romani, L. (2007): Chapter 2, Dentritic Cells. In: Brown., G. D. és Netea, M. G. (szerk.): Immunology of fungal infections. Springer, Dordrecht, 27-49.

Romani, L. (2011): Immunity to fungal infections. Nature Reviews Immunology, 11(4):275-288. doi:10.1038/nri2939

Roth, S., Bergmann, H., Jaeger, M., Yeroslaviz, A., Neumann, K., Koenig, P-A., da Costa, C. P., Vanes, L., Kumar, V., Johnson, M., Menacho-Márquez, M., Habermann, B., Tybulewicz, V. L., Netea, M., Bustelo, X. R. és Ruland, J. (2016): Vav Proteins Are Key Regulators of Card9 Signaling for Innate Antifungal Immunity. Cell Reports, 17(10):2572-2583. doi:10.1016/j.celrep.2016.11.018

Ruland, J. (2008): CARD9 Signaling in the Innate Immune Response. Annals of the New York Academy of Sciences, 1143(1):35-44. doi:10.1196/annals.1443.024

Sai, S., Holland, L. M., McGee, C. F., Lynch, D. B. és Butler, G. (2011): Evolution of Mating within the Candida parapsilosis Species Group. Eukaryotic Cell, 10(4):578-587. doi:10.1128/ec.00276-10

Salazar, F. és Brown, G. D. (2018): Antifungal Innate Immunity: A Perspective from the Last 10 Years. Journal of Innate Immunity, 10:373-397. doi:10.1159/000488539 
Sato, M., Sano, H., Iwaki, D., Kudo, K., Konishi, M., Takahashi, H., Takahashi, T., Imaizumi, H., Asai, Y. és Kuroki, Y. (2003): Direct Binding of Toll-Like Receptor 2 to Zymosan, and Zymosan-Induced NF-KB Activation and TNF- $\alpha$ Secretion Are Down-Regulated by Lung Collectin Surfactant Protein A. The Journal of Immunology, 171(1):417425. doi:10.4049/jimmunol.171.1.417

Segal, B. H., Kwon-Chung, J., Walsh, T. J., Klein, B. S., Battiwalla, M., Almyroudis, N. G., Holland, S. M. és Romani, L. (2006): Immunotherapy for Fungal Infections. Clinical Infectious Diseases, 42(4):507515. doi:10.1086/499811

Seider, K., Brunke, S., Schild, L., Jablonowski, N., Wilson, D., Majer, O., Barz, D., Haas, A., Kuchler, K., Schaller, M. és Hube, B. (2011): The Facultative Intracellular Pathogen Candida glabrata Subverts Macrophage Cytokine Production and Phagolysosome Maturation. The Journal of Immunology, 187(6):3072-3086. doi:10.4049/jimmunol.1003730

Shibata, N., Ikuta, K., Imai, T., Satoh, Y., Satoh, R., Suzuki, A., Kojima, C., Kobayashi, H., Hisamichi, K. és Suzuki, S. (1995): Existence of Branched Side Chains in the Cell Wall Mannan of Pathogenic Yeast, Candida albicans. Structure-Antigenicity Relationship Between the Cell Wall Mannans of Candida albicans and Candida parapsilosis. Journal of Biological Chemistry, 270(3):1113-1122. doi:10.1074/jbc.270.3.1113

Silva, S., Negri, M., Henriques, M., Oliveira, R., Williams, D. W. és Azeredo, J. (2012): Candida glabrata, Candida parapsilosis and Candida tropicalis: biology, epidemiology, pathogenicity and antifungal resistance. FEMS Microbiology Reviews, 36(2):288-305. doi:10.1111/j.15746976.2011.00278.x

Sinkó, J., Csomor, J., Nikolova, R., Lueff, S., Kriván, G., Reményi, P., Bátai, Á. és Masszi, T. (2008): Invasive fungal disease in allogeneic hematopoietic stem cell transplant recipients: an autopsy-driven survey. Transplant Infectious Disease, 10(2):106-109. doi:10.1111/j.1399-3062.2007.00264.x

Sinkó, J., Sulyok, M. és Denning, D. W. (2015): Burden of serious fungal diseases in Hungary. Mycoses, 58:29-33. doi:10.1111/myc.12385

Skeldon, A. és Saleh, M. (2011): The Inflammasomes: Molecular Effectors of Host Resistance Against Bacterial, Viral, Parasitic, and Fungal Infections. Frontiers in Microbiology, 2:15. doi:10.3389/fmicb.2011.00015

Spatafora, J., Aime, M., Grigoriev, I., Martin, F., Stajich, J. és Blackwell, M. (2017): The Fungal Tree of Life: From Molecular Systematics to Genome-Scale Phylogenies. In Heitman, J., Howlett, B., Crous, P., Stukenbrock, E., James, T. és Gow, N. (szerk.): The Fungal Kingdom. ASM Press, Washington, DC, 334. doi:10.1128/microbiolspec.FUNK-0053-2016

Stefándel, I. (1984): Szolnok megye humán bőrpatogén gombái 12 év vizsgálata alapján. Mikológiai Közlemények, Clusiana, 19(1):27-43.

Steinshamn, S., Bemelmans, M.H., van Tits, L. J., Bergh, K., Buurman, W. A. és Waage, A. (1996): TNF receptors in murine Candida albicans infection: evidence for an important role of TNF receptor p55 in antifungal defense. The Journal of Immunology, 157(5):2155-2159.

Strasser, D., Neumann, K., Bergmann, H., Marakalala, M. J., Guler, R., Rojowska, A., Hopfner, K-P., Brombacher, F., Urlaub, H., Baier, G., Brown, G. D., Leitges, M. és Ruland, J. (2012): Syk Kinase-Coupled C-type Lectin Receptors Engage Protein Kinase C- $\delta$ to Elicit Card9 Adaptor-Mediated Innate Immunity. Immunity, 36(1):32-42. doi:10.1016/j.immuni.2011.11.015

Swidergall, M., Solis, N. V., Lionakis, M. S. és Filler, S. G. (2017): EphA2 is an epithelial cell pattern recognition receptor for fungal $\beta$-glucans. Nature Microbiology, 3(1):53-61. doi:10.1038/s41564-0170059-5

Szodoray, L. (szerk.) (1957): Orvosi Mykológia. Akadémiai Kiadó, Budapest.

Tang, J., Lin, G., Langdon, W. Y., Tao, L. és Zhang, J. (2018): Regulation of C-Type Lectin ReceptorMediated Antifungal Immunity. Frontiers in Immunology, 9:123. doi:10.3389/fimmu.2018.00123 
Tavanti, A., Davidson, A. D., Gow, N. A., Maiden, M. C. és Odds, F. C. (2005): Candida orthopsilosis and Candida metapsilosis spp. nov. to replace Candida parapsilosis groups II and III. Journal of Clinical Microbiology, 43:284-292. doi:10.1128/JCM.43.1.284-292.2005

Taylor, J. W. (2014): Evolutionary Perspectives on Human Fungal Pathogens. Cold Spring Harbor Perspectives in Medicine, 5(9):a019588. doi:10.1101/cshperspect.a019588

Taylor, P. R., Tsoni, S. V., Willment, J. A., Dennehy, K. M., Rosas, M., Findon, H., Haynes, K., Steele, C., Botto, M., Gordon, S. és Brown, G. D. (2006): Dectin-1 is required for $\beta$-glucan recognition and control of fungal infection. Nature Immunology, 8(1):31-38. doi:10.1038/ni1408

Thompson, A., Griffiths, J. S., Walker, L., da Fonseca, D. M., Lee, K. K., Taylor, P. R., Gow, N. A. R. és Orr, S. J. (2019): Dependence on Dectin-1 Varies With Multiple Candida Species. Frontiers in Microbiology, 10:1800. doi:10.3389/fmicb.2019.01800

Tóth, A., Csonka, K., Jacobs, C., Vágvölgyi, C., Nosanchuk, J. D., Netea, M. G. és Gácser, A. (2013): Candida albicans and Candida parapsilosis Induce Different T-Cell Responses in Human Peripheral Blood Mononuclear Cells. The Journal of Infectious Diseases, 208(4):690-698. doi:10.1093/infdis/jit188

Tóth, A., Zajta, E., Csonka, K., Vágvölgyi, Cs., Netea, M. G. és Gácser, A. (2017): Specific pathways mediating inflammasome activation by Candida parapsilosis. Scientific Reports, 7:43129. doi: 10.1038/srep43129

Tóth, R., Alonso, M. F., Bain, J. M., Vágvölgyi, Cs., Erwig, L. P. és Gácser, A. (2015): Different Candida parapsilosis clinical isolates and lipase deficient strain trigger an altered cellular immune response. Frontiers in Microbiology, 6:1102. doi: 10.3389/fmicb.2015.01102

Tóth, R., Cabral, V., Thuer, E., Bohner, F., Németh, T., Papp, C., Nimrichter, L., Molnár, G., Vágvölgyi, Cs., Gabaldón, T., Nosanchuk J. D. és Gácser, A. (2018): Investigation of Candida parapsilosis virulence regulatory factors during host-pathogen interaction. Scientific Reports, 8:1346. doi:10.1038/s41598018-19453-4

Tóth, R., Nosek, J., Mora-Montes, H. M., Gabaldon, T., Bliss, J. M., Nosanchuk, J. D., Turner, S. A., Butler, G., Vágvölgyi, Cs. és Gácser, A. (2019): Candida parapsilosis: from Genes to the Bedside. Clinical Microbiology Reviews, 32(2):e00111-18. doi: 10.1128/CMR.00111-18

Tóth, R., Tóth, A., Vágvölgyi, Cs. és Gácser, A. (2017b): Candida parapsilosis secreted lipase as an important virulence factor. Current Protein and Peptid Science, 18(10):1043-1049. doi10.2174/1389203717666160813163054

Treviño-Rangel, R. de J., González, G. M., Martínez-Castilla, A. M., García-Juárez, J., Robledo-Leal, E. R., González, J. G. és Rosas-Taraco, A. G. (2015): Candida parapsilosis complex induces local inflammatory cytokines in immunocompetent mice. Medical Mycology, 53(6):612-621. doi:10.1093/mmy/myv021

Trofa, D., Gácser, A. és Nosanchuk, J. D. (2008): Candida parapsilosis, an Emerging Fungal Pathogen. Clinical Microbiology Reviews, 21(4):606625. doi:10.1128/cmr.00013-08

Tsoni, S. V., Kerrigan, A. M., Marakalala, M. J., Srinivasan, N., Duffield, M., Taylor, P. R., Botto, M., Steele, C. és Brown, G. D. (2009): Complement C3 Plays an Essential Role in the Control of Opportunistic Fungal Infections. Infection and Immunity, 77(9):3679-3685. doi:10.1128/iai.00233-09

Turner, M., Joseph Mee, P., Costello, P. S., Williams, O., Price, A. A., Duddy, L. P., Furlong, M. T., Geahlen, R. L. és Tybulewicz, V. L. J. (1995): Perinatal lethality and blocked B-cell development in mice lacking the tyrosine kinase Syk. Nature, 378(6554):298-302. doi:10.1038/378298a0

Turner, S. A. és Butler, G. (2014): The Candida Pathogenic Species Complex. Cold Spring Harbor Perspectives in Medicine, 4(9):a019778-a019778. doi:10.1101/cshperspect.a019778 
Underhill, D. M., Rossnagle, E., Lowell, C. A. és Simmons, R. M. (2005): Dectin-1 activates Syk tyrosine kinase in a dynamic subset of macrophages for reactive oxygen production. Blood, 106(7):2543-2550. doi:10.1182/blood-2005-03-1239

Van Asbeck, E. C., Hoepelman, A. I., Scharringa, J., Herpers, B. L. és Verhoef, J. (2008): Mannose binding lectin plays a crucial role in innate immunity against yeast by enhanced complement activation and enhanced uptake of polymorphonuclear cells. BMC Microbiology, 8(1):229. doi:10.1186/14712180-8-229

Vanaja, S. K., Rathinam, V. A. K. és Fitzgerald, K. A. (2015): Mechanisms of inflammasome activation: recent advances and novel insights. Trends in Cell Biology, 25(5):308-315. doi:10.1016/j.tcb.2014.12.009

Van Uden, N. és Carmo-Sousa, L. D. (1962): On the intestinal yeast flora of free living hippopotami (Hippopotamus amphibius), wart hogs (Phacochoerus aethiopicus) and bush pigs (Potamochoerus choeropotamus). Antonie van Leeuwenhoek, 28(1):73-77. doi:10.1007/bf02538723

Verma, A., Wuthrich, M., Deepe, G. és Klein, B. (2014): Adaptive Immunity to Fungi. Cold Spring Harbor Perspectives in Medicine, 5(3):a019612-a019612. doi:10.1101/cshperspect.a019612

Villamón, E., Gozalbo, D., Roig, P., O’Connor, J. E., Fradelizi, D. és Gil, M. L. (2004): Toll-like receptor2 is essential in murine defenses against Candida albicans infections. Microbes and Infection, 6(1):1-7. doi:10.1016/j.micinf.2003.09.020

Wagener, J., Malireddi, R. K. S., Lenardon, M. D., Köberle, M., Vautier, S., MacCallum, D. M., Biedermann, T., Schaller, M., Netea, M. G.,Kanneganti, T-D., Brown, G. D., Brown, A. J. P. és Gow, N. A. R. (2014): Fungal Chitin Dampens Inflammation through IL-10 Induction Mediated by NOD2 and TLR9 Activation. PLoS Pathogens, 10(4):e1004050. doi:10.1371/journal.ppat.1004050

Wang, C., Yu, X., Cao, Q., Wang, Y., Zheng, G., Tan, T. K., Zhao, H., Zhao, Y., Wang, Y. és Harris, D. C. (2013): Characterization of murine macrophages from bone marrow, spleen and peritoneum. BMC Immunology, 14(1):6. doi:10.1186/1471-2172-14-6

Wang, L., Duke, L., Zhang, P. S., Arlinghaus, R. B., Symmans, W. F., Sahin, A., Mendez, R. és Dai, J. L. (2003): Alternative splicing disrupts a nuclear localization signal in spleen tyrosine kinase that is required for invasion suppression in breast cancer. Cancer Research, 63:4724-4730.

Wang, Q., Shen, L., Ye, T., Cao, D., Chen, R., Pei, X., Xie, T., Li, Y., Gong, W. és Yin, X. (2012): Bioresource technology overexpression and characterization of a novel (S)-specific extended shortchain dehydrogenase/reductase from Candida parapsilosis. Bioresource Technology, 123:690-694. doi:10.1016/j.biortech.2012.07.060

Wang, T., Pan, D., Zhou, Z., You, Y., Jiang, C., Zhao, X. és Lin, X. (2016): Dectin-3 Deficiency Promotes Colitis Development due to Impaired Antifungal Innate Immune Responses in the Gut. PLOS Pathogens, 12(6):e1005662. doi:10.1371/journal.ppat.1005662

Wang, W., Deng, Z., Wu, H., Zhao, Z., Li, T., Zhu, W., Wang, X., Tang, L., Wang, C., Cui, S-Z., Xiao, H. és Chen, J. (2019): A small secreted protein triggers a TLR2/4-dependent inflammatory response during invasive Candida albicans infection. Nature Communications, 10:1015. doi:10.1038/s41467-01908950-3

Wells, C. A., Salvage-Jones, J. A., Li, X., Hitchens, K., Butcher, S., Murray, R. Z., Beckhouse, A. G., Lo, Y-L-S., Manzanero, S., Cobbold, C., Schroder, K., Ma, B., Orr, S., Stewart, L., Lebus, D., Sobieszczuk, P., Hume, D. A., Stow, J., Blanchard, H. és Ashman, R. B. (2008): The Macrophage-Inducible C-Type Lectin, Mincle, Is an Essential Component of the Innate Immune Response to Candida albicans. The Journal of Immunology, 180(11):7404-7413. doi:10.4049/jimmunol.180.11.7404

Whibley, N., Jaycox, J. R., Reid, D., Garg, A. V., Taylor, J. A., Clancy, C. J., Nguyen, M. H., Biswas, P. S., McGeachy, M. J., Brown, G. D. és Gaffen, S. L. (2015): Delinking CARD9 and IL-17: CARD9 Protects 
against Candida tropicalis Infection through a TNF- $\alpha$-Dependent, IL-17-Independent Mechanism. The Journal of Immunology, 195(8):3781-3792. doi:10.4049/jimmunol.1500870

Whitney, P. G., Bär, E., Osorio, F., Rogers, N. C., Schraml, B. U., Deddouche, S., LeibundGutLandmann, S. és e Sousa, C. R. (2014): Syk Signaling in Dendritic Cells Orchestrates Innate Resistance to Systemic Fungal Infection. PLoS Pathogens, 10(7):e1004276. doi:10.1371/journal.ppat.1004276

Willinger, B., Hillowoth, C., Selitsch, B. és Manafi, M. (2001): Performance of Candida ID, a New Chromogenic Medium for Presumptive Identification of Candida Species, in Comparison to CHROMagar Candida. Journal of Clinical Microbiology, 39(10):3793-3795. doi:10.1128/jcm.39.10.3793-3795.2001

Willinger, B. és Manafi, M. (1999): Evaluation of CHROMagar Candida for rapid screening of clinical specimens for Candida species. Mycoses, 42(1-2):61-65. doi:10.1046/j.1439-0507.1999.00406.x

Wiseman, J. C. D. és Mody, C. H. (2007): Chapter 5, Other Cells: The Role of Non-Neutrophilic Granulocytes, NK And NKT Cells In Fungal Immunology. In: Brown., G. D. és Netea, M. G. (szerk.): Immunology of fungal infections. Springer, Dordrecht, 99-130.

Xue, Z-H., Feng, C., Liu, W-L. és Tan, S-M. (2013): A Role of Kindlin-3 in Integrin $\alpha M \beta 2$ Outside-In Signaling and the Syk-Vav1-Rac1/Cdc42 Signaling Axis. PLoS ONE, 8(2):e56911. doi:10.1371/journal.pone.0056911

Yapar, N. (2014): Epidemiology and risk factors for invasive candidiasis. Therapeutics and Clinical Risk Management, 10:95-105. doi:10.2147/tcrm.s40160

Zajd, C. M., Ziemba, A. M., Miralles, G. M., Nguyen, T., Feustel, P. J., Dunn, S. M., Gilbert, R. J. és Lennartz, M. R. (2020). Bone Marrow-Derived and Elicited Peritoneal Macrophages Are Not Created Equal: The Questions Asked Dictate the Cell Type Used. Frontiers in Immunology, 11:269. doi:10.3389/fimmu.2020.00269

Zala, J. (1997): Mikológiai Osztály. In: Pápay, D.: A „Johan Béla" Országos Közegészségügyi Intézet Múködése az 1996. évben. OKI, Budapest, 185-189.

Zala, J. (1998): Mikológiai Osztály. In: Pápay, D.: A „Johan Béla" Országos Közegészségügyi Intézet 70 éves Múködése, 1927-1997. OKI, Budapest, 327-331.

Zala, J. (1999): Mikológiai Osztály. In: Straub, I.: A „Johan Béla" Országos Epidemiológiai Központ Múködése az 1998. évben. OKK, Budapest, 86-92.

Zala, J. (2000): Mikológiai Osztály. In: Straub, I.: A „Johan Béla" Országos Epidemiológiai Központ Működése az 1999. évben. OKK, Budapest, 96-102.

Zala, J. (2001): Mikológiai Osztály. In: Straub, I.: A „Johan Béla" Országos Epidemiológiai Központ Múködése a 2000. évben. OKK, Budapest, 101-107.

Zala, J. (2002): Mikológiai Osztály. In: Melles, M.: A „Johan Béla" Országos Epidemiológiai Központ Múködése a 2001. évben. OKK, Budapest, 110-116.

Zala, J. (2003): Mikológiai Osztály. In: Melles, M.: A „Johan Béla" Országos Epidemiológiai Központ Múködése a 2002. évben. Pharma Press, Budapest, 111-117.

Zala, J. (2004): Mikológiai Osztály. In: Melles, M.: A „Johan Béla" Országos Epidemiológiai Központ Múködése a 2003. évben. Pharma Press, Budapest, 151-156.

Zala, J. (2005): Mikológiai Osztály. In: Melles, M.: A „Johan Béla" Országos Epidemiológiai Központ Múködése a 2004. évben. Dursusz, Budapest, 171-176.

Zala, J. (2006): Mikológiai Osztály. In: Melles, M.: A „Johan Béla" Országos Epidemiológiai Központ Múködése a 2005. évben. Dursusz, Budapest, 159-165.

Zala, J. (2007): Mikológiai Osztály. In: Melles, M.: Az Országos Epidemiológiai Központ Múködése a 2006. évben. Szerif, Budapest, 153-157. 
Zala, J. (2008): Mikológiai Osztály. In: Melles, M.: Az Országos Epidemiológiai Központ Múködése a 2007. évben. Dursusz, Budapest, 185-188.

Zala, J. (2009): Mikológiai Osztály. In: Melles, M.: Az Országos Epidemiológiai Központ Múködése a 2008. évben. Dursusz, Budapest, 159-163.

Zala, J. (2010): Mikológiai Osztály. In: Melles, M.: Az Országos Epidemiológiai Központ Múködése a 2008. évben. Dursusz, Budapest, 146-150.

Zala, J. (2012): Mikológiai Osztály. In: Melles, M.: Az Országos Epidemiológiai Központ Múködése a 2011. évben. Dursusz, Budapest, 154-157.

Zalatnai, A., Zala, J. és Sándor, G. (1998): Coccidioidomycosis in Hungary. Pathology and Oncology Research, 4(2):147-151. doi:10.1007/bf02904709

Zhang, X., Goncalves, R. és Mosser, D. M. (2008): The isolation and characterization of murine macrophages. Current Protocols in Immunology, Unit 14.1. doi:10.1002/0471142735.im1401s83

Zhao, Y., Tian, P., Han, F., Zheng, J., Xia, X., Xue, W., Ding, X. és Ding, C. (2017): Comparison of the characteristics of macrophages derived from murine spleen, peritoneal cavity, and bone marrow. Journal of Zhejiang University-SCIENCE B (Biomedicine \& Biotechnology), 18(12):1055-1063. doi:10.1631/jzus.b1700003

Zhernakova, A., Festen, E. M., Franke, L., Trynka, G., van Diemen, C. C., Monsuur, A. J., Bevova, M., Nijmeijer, R. M., van 't Slot, R., Heijmans, R., Boezen, H. M., van Heel, D. A., van Bodegraven, A. A., Stokkers, P. C. F., Wijmenga,C., Crusius, J. B. A. és Weersma, R. K. (2008): Genetic Analysis of Innate Immunity in Crohn's Disease and Ulcerative Colitis Identifies Two Susceptibility Loci Harboring CARD9 and IL18RAP. The American Journal of Human Genetics, 82(5):1202-1210. doi:10.1016/j.ajhg.2008.03.016

Zhou, Y., Ye, H., Martin-Subero, J. I., Hamoudi, R., Lu, Y-J., Wang, R., Siebert, R., Shipley, J., Isaacson, P. G., Dogan, A. és Du, M-Q. (2006): Distinct comparative genomic hybridisation profiles in gastric mucosa-associated lymphoid tissue lymphomas with and without $t(11 ; 18)(q 21 ; q 21)$. British Journal of Haematology, 133(1):35-42. doi:10.1111/j.1365-2141.2006.05969.x

Zhu, L-L, Zhao, X-Q, Jiang, C., You, Y., Chen, X-P., Jiang, Y-Y., Jia, X-M. és Lin, X. (2013): C-Type Lectin Receptors Dectin-3 and Dectin-2 Form a Heterodimeric Pattern-Recognition Receptor for Host Defense against Fungal Infection. Immunity, 39(2):324-334. doi:10.1016/j.immuni.2013.05.017 


\section{Köszönetnyilvánítás}

Legelső helyen szüleimnek, családomnak és élettársamnak köszönöm meg a feltétlen érzelmi, erkölcsi és anyagi támogatást, amely egyáltalán lehetővé tette, hogy eljussak a doktori képzésig és Szegeden éljek több mint 4 évig. Ti vagytok számomra a biztos alap.

A szakmából legelőször Prof. Dr. Vágvölgyi Csabának, a Szegedi Tudományegyetem Természettudományi és Informatikai Kar Mikrobiológiai Tanszék vezetőjének mondok köszönetet, amiért hozzájárulásával lehetővé tette, hogy a tanszéken végezzem a doktori iskolát.

Különösen hálás vagyok témavezetőmnek, Prof. Dr. Gácser Attilának. Ö nemcsak szakmai tudásával, hanem bíztatásával és példájával is támogatott. Köszönöm a részvételi lehetőséget a sok konferencián, hogy közelről megismerhettem szakterületünk nemzetközi tudományos közösségét, továbbá annak a munkaközegnek az elősegítését, ahol a munkatársak egymást felfelé húzzák. Köszönöm a belém helyezett bizalmat. Ö és a Tanszékvezető Úr ugyanis annak ellenére járultak hozzá felvételemhez a PhD képzésre, hogy tudatában voltak annak, hogy egy másik megcélzott képzési programért potenciálisan abbahagytam volna a szegedit. Ezért különösen hálás vagyok. Témavezetőm továbbá gyakran olyan főnöknek bizonyult, aki dicsérettel is motivál és akit nemcsak tisztelni, de szeretni is lehet.

Köszönettel tartozom az általa vezetett kutatócsoport tagjainak is: Dr. Tóth Adélnak, Dr. Csonka Katalinnak, Dr. Tóth Renátának, Dr. Papp Csabának, Dr. Németh Tibornak, Dr. Grózer Zsuzsannának, Szenzenstein Juditnak, Dr. Tanmoy Chakraborty-nak, Dr. Dhirendra K. Singh-nek, Bernátsky Reginának, Kocsis Katicának, Drabbant Gergőnek, Balla Benediktának, Bohner Flórának, Takács Tamásnak, Vadovics Máténak, Pál Sárának, Veres Évának, Halmos Emesének, Csikós Máténak, Horváth Mártonnak és Tasi Zsoltnak amiért olyan munkakörnyezetet teremtettek számomra, ahova öröm volt bejárni dolgozni. Néhányuknak kiemelten hálás vagyok. Dr. Tóth Adél volt az, akitől a Candida gombákkal és az emlős sejtkultúrákkal történő munka alapjait tanulhattam meg és akivel együtt dolgozhattam az NLRP3 inflammaszómával kapcsolatos munkában. Ö volt számomra a jó PhD hallgató példája. Adél, azt hiszem, jobb tanárt nem is kívánhattam volna a doktori képzésem elejére! Dr. Csonka Katalintól az egerekkel kapcsolatos kísérleti módszereket tanultam meg és mindig számíthattam segítségére, jóindulatára, éles és építő kritikájára. Köszönöm, Katika, a sok fáradtságot, de leginkább a megtisztelő barátságodat! Dr. Németh Tibor igazi ezermester, aki szintén készséges volt a segítségnyújtásban, és tőle kaptam a GFP-CLIB214 törzset használatra. Tibi, sok motivációt merítettem belöled! Dr. Tóth Renátának köszönöm a szakmai tippeket és 
beszélgetéseket és a kedvességet. Dr. Papp Csaba szakmai (pl. mikroszkópia) segítségére is mindig számíthattam. Csabi, neked külön köszönöm a jókedvet! Halmos Emesének és Csikós Máténak nagyon köszönöm a munkájukat. Gratulálok nektek a TDK-val kapcsolatos sikereitekhez!

A tanszék többi kollégájának is hálás vagyok. Én azt tapasztaltam, hogy olyan hellyé teszik a tanszéket, ahol az embert nem nézik ki, ha egy-egy butaságot kérdez vagy segítséget kér, hanem jószándékúan segítségére vannak. Külön köszönöm a támogatást Dr. Ámon Juditnak, Dr. Bokor Eszternek és Dr. Tóth Eszternek.

Prof. Dr. Mócsai Attila bocsátotta rendelkezésemre az összes csontvelői kiméra egeret, melyek létrehozásáért Dr. Németh Tamás, Csepregia Janka Annamária, Orosz Anita és Szénási Nikolett felelt, mindannyiaknak hálásan köszönöm a sok munkát! Prof. Dr. Tiszlavicz Lászlónak és Daru Krisztiánmak a szövettani munkában nyújtott segítségüket köszönöm! A tanszéken kívüli további kollégák közül köszönöm Dr. Marton Annamáriának az egér kísérletek során nyújtott segítséget. Dr. Kiricsi Mónika, Dr. Kovács Dávid, Igaz Nóra és Dr. Virágh Máté nagy segítségemre voltak a western blot technikával kapcsolatban, ezt köszönöm feléjük.

Házi bírálóimnak, Dr. Homa Mónikának és Dr. Honti Viktornak köszönöm, hogy értékes szakmai és formai vonatkozású bírálataikkal segítették a dolgozat végleges verziójának kialakítását, és felhívták a figyelmemet a magyar nyelv ellen elkövetett merényleteimre.

Korábbi témavezetőimnek, Dr. Jakucs Erzsébetnek, Prof. Dr. Kovács M. Gábornak és Prof. Dr. Elaine Bignellnek hálás vagyok amiért példájukkal a PhD képzés felé tereltek.

Végül barátaimnak köszönöm meg, hogy szegedi éveim során nem hanyagoltak el. Az ELTE-s biológus barátaim közül emellett többen igen nagy szakmai motivációt is jelentettek számomra ahhoz, hogy befejezzem a doktori disszertációmat. Máté, te mindig is úttörő voltál a társaságban, együtt örülök veled a nagyszerü sikereidnek! Marci, gratulálok a sikeres $\mathrm{PhD}$ fokozatszerzéshez, az itthoniak közül te vagy az első, aki ezt elérte. Kinga, Dani, csak így tovább a szakmában, nem semmi, amit máris elértetek! Knapp Dani, köszönöm a sok belém fektetett energiát évekkel korábban, amikor gombákkal való laboratóriumi munkára az elsők között tanítottál. Töretlenül felnézek rád! Torda, neked nem csak a gombák iránti szeretetben való osztozást, a sikereidböl és kemény munkádból származó szakmai ösztönzést köszönöm, hanem hogy egy ideig lakótársak voltunk $\mathrm{PhD}$ képzésünk alatt, ami tovább erősítette barátságunkat.

Munkámat a GINOP-2.3.2-15-2016-00015, az NKFIH K123952 projektek és az Emberi Erőforrás Támogatáskezelő által meghirdetett, „Nemzet Fiatal Tehetségeiért Ösztöndíj” támogatta. 


\section{Függelék}

Függelék 1. táblázat. Gomba eredetü PAMP-ok felismerésében részt vevő PRR-ek. Feketével vannak szedve azon receptorok, melyekről kimutatták, hogy Candida spp. felismerésében is szerepet játszanak. A negyedik oszlopban olyan kórképeket soroltunk fel, melyekre az adott receptor egyes polimorfizmusai hajlamosító tényezőt jelentenek. CMC: krónikus mukokután kandidiázis; ?: nem ismert pontosan vagy nem tudunk ilyenről. Richardson és mtsai. (1991), Brown és Gordon (2005), Netea és mtsai. (2008), Romani (2011), Brown (2011), Bourgeois és mtsai. (2011), Drummond (2014), Verma és mtsai. (2014), Lee és Kim (2014), Hu és mtsai. (2015), Netea és mtsai. (2015), Lionakis és mtsai. (2017), Swidergall és mtsai. (2017), Dambuza és mtsai. (2017, 2018), Goyal és mtsai. (2018), Salazar és Brown (2018), illetve Wang és mtsai. (2019) alapján.

\begin{tabular}{|c|c|c|c|}
\hline Receptor (PRR) & Ligandum (PAMP) & Lokalizáció & $\begin{array}{c}\text { Polimorfizmusa } \\
\text { hajlamosító tényező }\end{array}$ \\
\hline \multicolumn{4}{|c|}{ I. C-típusú lektinek } \\
\hline Dectin-1 & $\beta$-1,3-glükán & plazmamembrán & $\begin{array}{l}\text { CMC, invazív } \\
\text { aszpergillózis }\end{array}$ \\
\hline Dectin-2 & $\begin{array}{l}\text { a-mannán, O-kapcsolt } \\
\text { mannán }\end{array}$ & plazmamembrán & $\begin{array}{c}\text { pulmonális } \\
\text { kriptokokkózis }\end{array}$ \\
\hline Dectin-3 & $\alpha$-mannán & plazmamembrán & ? \\
\hline Mincle & $\begin{array}{c}\alpha \text {-mannán, } \\
\text { gliceroglikolipidek }\end{array}$ & plazmamembrán & $?$ \\
\hline DC-SIGN & $\begin{array}{l}\text { N-kapcsolt mannán, } \\
\text { galaktomannán }\end{array}$ & plazmamembrán & $\begin{array}{c}\text { invazív pulmonális } \\
\text { aszpergillózis, gombás } \\
\text { keratitisz } \\
\end{array}$ \\
\hline Mannóz receptor & $\begin{array}{l}\text { N-kapcsolt mannán, } \\
\text { N-acetil-glükózamin }\end{array}$ & plazmamembrán & $?$ \\
\hline Mannóz kötő lektin & N-kapcsolt mannán & extracelluláris & $\begin{array}{c}\text { kandidiázis, } \\
\text { aszpergillózis }\end{array}$ \\
\hline CD23 & $\begin{array}{l}\beta \text {-glükán, } \\
\alpha \text {-mannán }\end{array}$ & plazmamembrán & $?$ \\
\hline MelLec & DHN-melanin & plazmamembrán & $\begin{array}{c}\text { őssejt } \\
\text { transzplantáltakban } \\
\text { invazív aszpergillózis }\end{array}$ \\
\hline Langerin & $\beta$-glükán & plazmamembrán & $\begin{array}{c}? \\
\end{array}$ \\
\hline SP-A és SP-D & $\begin{array}{l}\text { } \beta \text {-glükán, } \\
\text { glükuronoxilomannán }\end{array}$ & extracelluláris & $?$ \\
\hline \multicolumn{4}{|c|}{$\begin{array}{c}\text { II. S-típusú lektinek } \\
\end{array}$} \\
\hline Galektin-3 & $\beta$-1,2-mannán & $\begin{array}{c}\text { plazmamembrán, } \\
\text { extracelluláris }\end{array}$ & $?$ \\
\hline \multicolumn{4}{|c|}{$\begin{array}{c}\text { III. Toll-szerü receptorok } \\
\end{array}$} \\
\hline TLR1 & $\begin{array}{l}\text { TLR2-vel dimerként: } \\
\text { glükuronoxilomannán }\end{array}$ & plazmamembrán & $\begin{array}{c}\text { invazív aszpergillózis, } \\
\text { kandidémia } \\
\end{array}$ \\
\hline TLR2 & $\begin{array}{c}\alpha-1,4-\text { glükán, } \\
\text { glikolipidek, Sel1fehérje }\end{array}$ & plazmamembrán & $?$ \\
\hline TLR3 & dupla szálú RNS & endoszóma membrán & kután kandidiázis \\
\hline TLR4 & $\begin{array}{l}\text { O-kapcsolt mannán, } \\
\text { ramnomannán, } \\
\text { Sel1fehérje }\end{array}$ & plazmamembrán & $\begin{array}{c}\text { pulmonális } \\
\text { aszpergillózis, } \\
\text { kandidémia } \\
\end{array}$ \\
\hline TLR6 & $\begin{array}{l}\text { TLR2-vel dimerként: } \\
\text { foszfolipomannán, } \\
\text { glükuronoxilomannán }\end{array}$ & plazmamembrán & $\begin{array}{c}\text { össejt } \\
\text { transzplantáltakban } \\
\text { invazív aszpergillózis }\end{array}$ \\
\hline TLR7 & egyszálú RNS? & endoszóma membrán & $?$ \\
\hline TLR9 & $\begin{array}{l}\text { kitin egységek, } \\
\text { metilálatlan DNS }\end{array}$ & endoszóma membrán & $\begin{array}{c}\text { allergiás } \\
\text { bronchopulmonális } \\
\text { aszpergillózis }\end{array}$ \\
\hline
\end{tabular}




\begin{tabular}{|c|c|c|c|}
\hline \multicolumn{4}{|c|}{ IV. Pentraxinok } \\
\hline Pentraxin-3 & galaktomannán & extracelluláris & $\begin{array}{c}\text { őssejt } \\
\text { transzplantáltakban } \\
\text { invazív aszpergillózis }\end{array}$ \\
\hline C-reaktív protein & foszfokolin & extracelluláris & $?$ \\
\hline \multicolumn{4}{|c|}{ V.Scavanger receptorok } \\
\hline CD5 & $\beta$-glükán & plazmamembrán & $?$ \\
\hline CD36 & $\beta$-glükán & plazmamembrán & $?$ \\
\hline SCARF-1 & $\beta$-glükán, mannán & plazmamembrán & $?$ \\
\hline MARCO & ? & plazmamembrán & $?$ \\
\hline \multicolumn{4}{|c|}{ VI. NOD-szerü receptorok } \\
\hline NOD2 & kitin & citoplazma & ? \\
\hline NLRP3 & $?$ & citoplazma & $\begin{array}{l}\text { visszatérö vulvovaginális } \\
\text { kandidiázis } \\
\end{array}$ \\
\hline NLRP10 & $?$ & citoplazma & $\begin{array}{c}? \\
\end{array}$ \\
\hline NLRC4 & $?$ & citoplazma & $?$ \\
\hline \multicolumn{4}{|c|}{ VII. Integrinek } \\
\hline CR3 & $\begin{array}{c}\beta \text {-glükán, } \\
\text { glükuronoxilomannán }\end{array}$ & plazmamembrán & $?$ \\
\hline VLA-5 & ciklofilin $\mathrm{A}$ & plazmamembrán & $?$ \\
\hline \multicolumn{4}{|c|}{ VIII. RIG-I-szerü receptorok } \\
\hline MDA-5 & $?$ & citoplazma & disszeminált kandidiázis \\
\hline \multicolumn{4}{|c|}{ IX. Receptor tirozin kinázok } \\
\hline EphA2 & $\beta$-glükán & plazmamembrán & orális kandidiázis \\
\hline \multicolumn{4}{|c|}{ X.Fikolinok } \\
\hline Fikolin-2 & $\begin{array}{c}\beta-1,3 \text {-glükán, } \\
\text { N-acetil-glükózamin }\end{array}$ & extracelluláris & $?$ \\
\hline \multicolumn{4}{|c|}{$\begin{array}{c}\text { XI. Glikoszfingolipidek } \\
\end{array}$} \\
\hline Laktozilceramid & $\beta$-glükán & plazmamembrán & $?$ \\
\hline
\end{tabular}




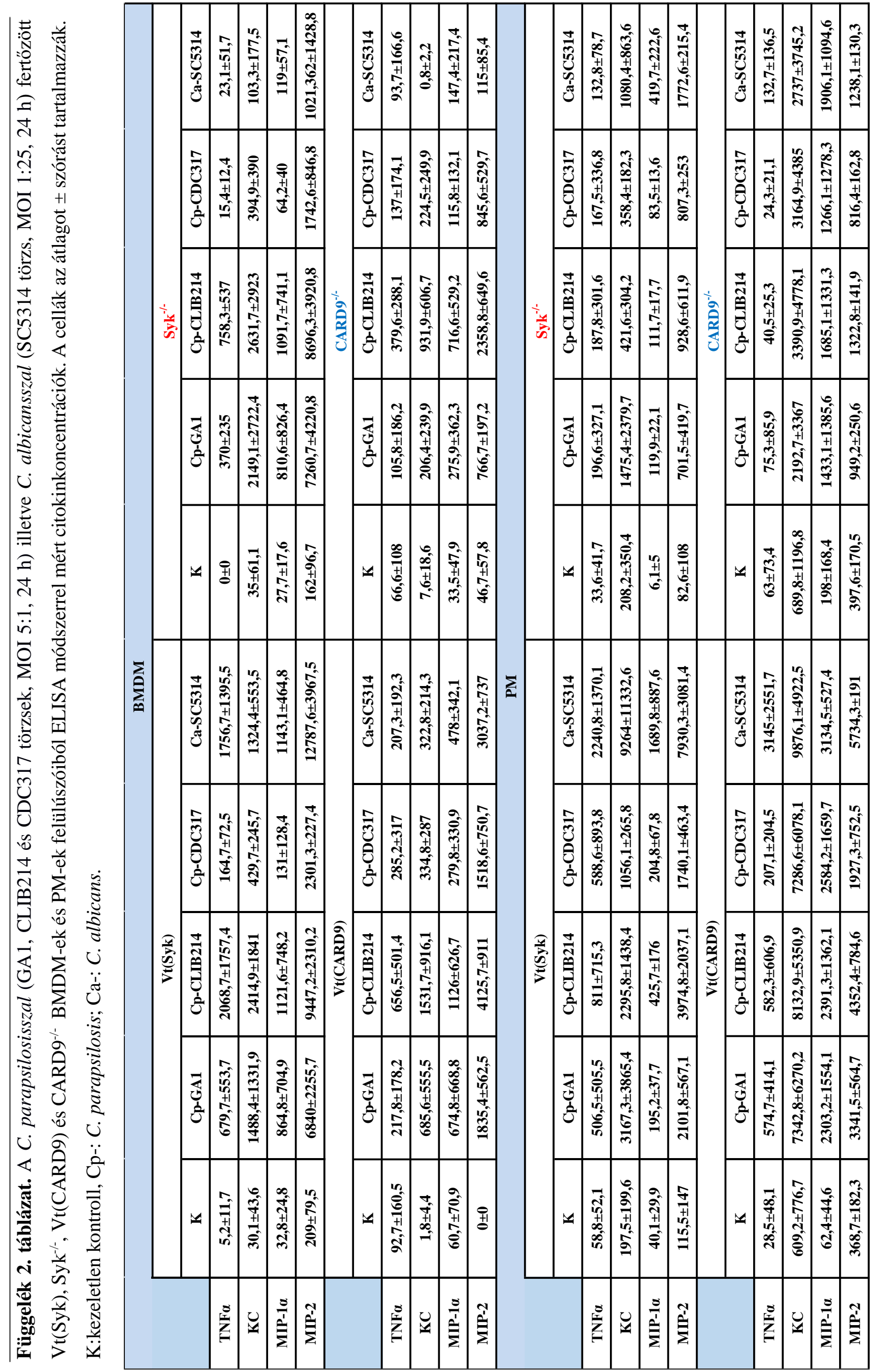


Függelék 3. táblázat. A dolgozatban bemutatott eredmények táblázatos összefoglalása vázlatosan.

\begin{tabular}{|c|c|}
\hline Kísérlet & Eredmény \\
\hline NF-кB p65 transzlokáció & C. parapsilosis: BMDM: Syk- és CARD9-függő \\
\hline Citokinteremelés & $\begin{array}{l}\text { C. parapsilosis: } \\
\text {-BMDM: TNF } \alpha \text { Syk- és CARD9 függő, kemokintermelés Syk-független, } \\
\text { de CARD9-függő } \\
\text {-PM: TNF } \alpha \text { - és kemokintermelés is Syk- és CARD9-függő } \\
\text { C. albicans: } \\
\text {-BMDM: TNF } \alpha \text { - és kemokintermelés is Syk- és CARD9-függő } \\
\text {-PM: TNF } \alpha \text { - és kemokintermelés is Syk- és CARD9-függő }\end{array}$ \\
\hline Fagocitózis & $\begin{array}{l}\text { C. parapsilosis: } \\
\text {-BMDM: Syk-függö, de CARD9-független } \\
\text {-PM: Syk-függö, de CARD9-független } \\
\text { C. albicans: } \\
\text {-BMDM: Syk-függö, de CARD9-független } \\
\text {-PM: Syk-függö, de CARD9-független }\end{array}$ \\
\hline Fagoszóma savasodás & $\begin{array}{l}\text { C. parapsilosis: } \\
\text {-BMDM: Syk-függő, de CARD9-független } \\
\text {-PM: Syk-függö, de CARD9-független } \\
\text { C. albicans: } \\
\text {-BMDM: Syk-függő, de CARD9-független } \\
\text {-PM: Syk-függö, de CARD9-független }\end{array}$ \\
\hline Elimináció & $\begin{array}{l}\text { C. parapsilosis: } \\
\text {-BMDM: Syk-függő, de CARD9-független } \\
\text {-PM: Syk- és CARD9-független }\end{array}$ \\
\hline In vivo rezisztencia & $\begin{array}{l}\text { C. parapsilosis: Syk- és CARD9-függő, kiemelten a késői (30. nap) } \\
\text { idpőpontban } \\
\text { C. albicans: Syk- és CARD9-függő, már korai időpontban (2. nap) } \\
\text { hangsúlyos szerep }\end{array}$ \\
\hline
\end{tabular}




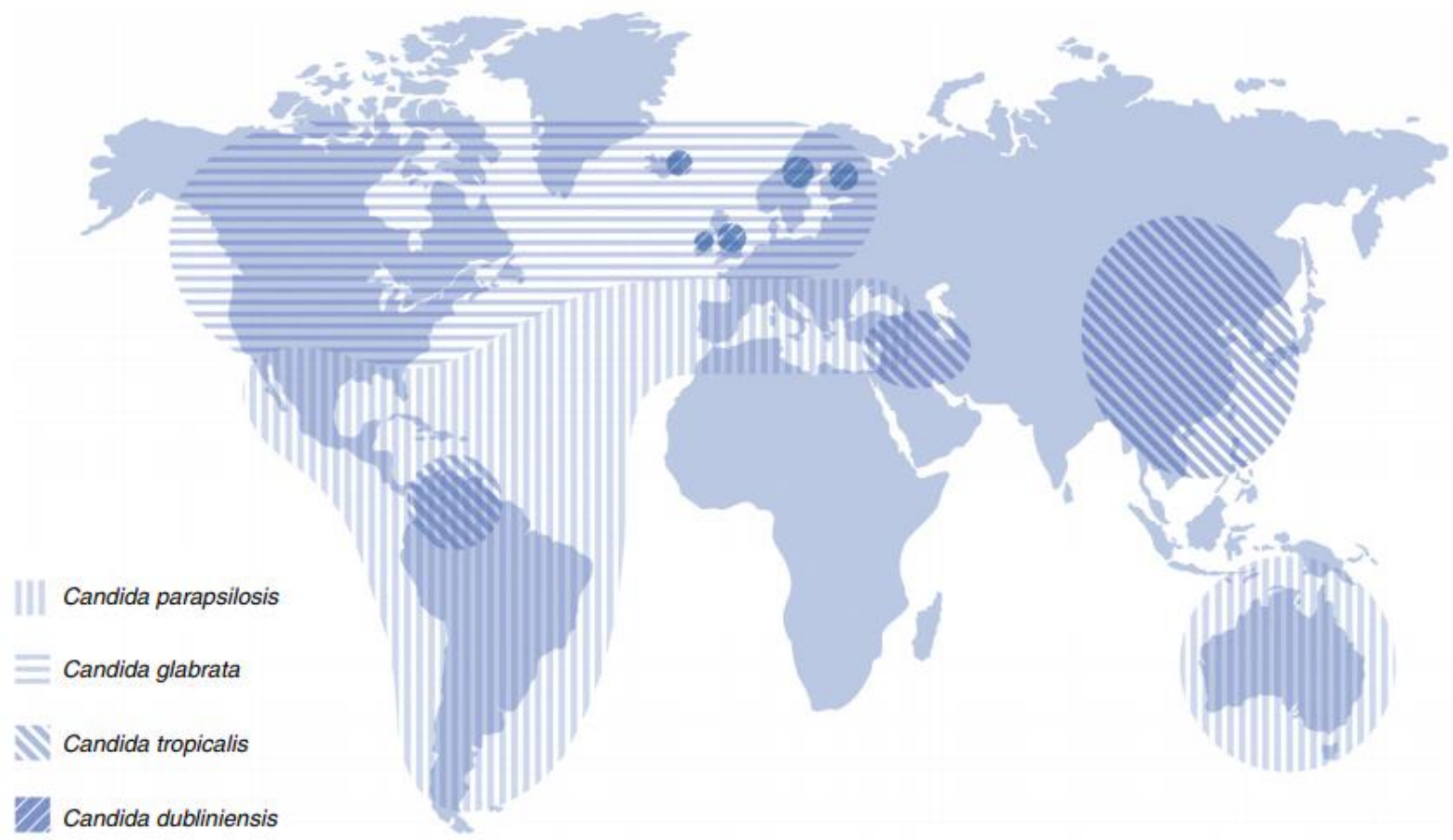

Függelék 1. ábra. Kandidémiából izolált ismertebb non-albicans fajok földrajzi eloszlása. Az ábra azt mutatja be, hogy egy adott térségben melyik fajt tenyésztették ki leggyakrabban (Quindós 2014).

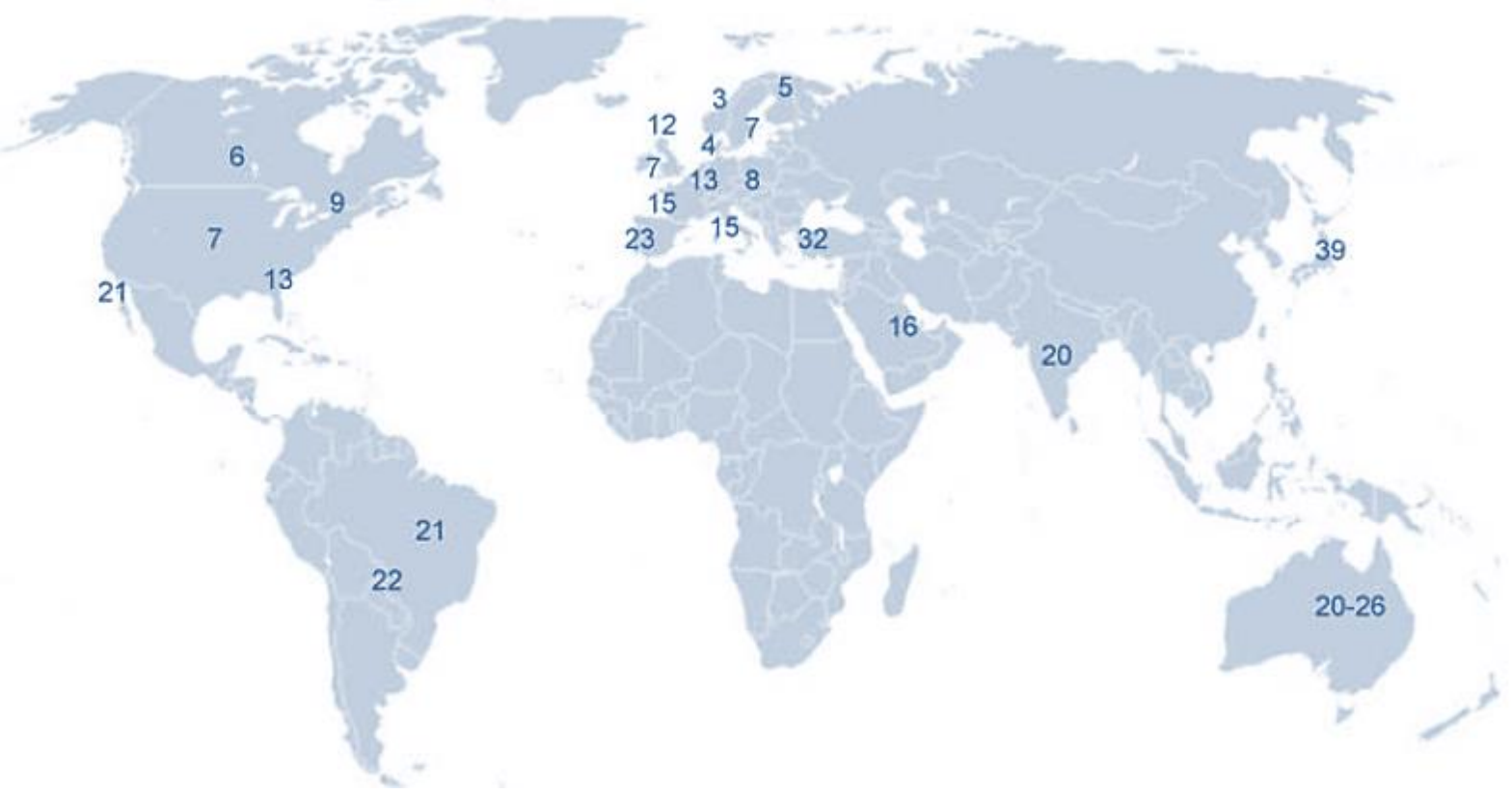

Függelék 2. ábra. A C. parapsilosis kandidémiából történő izolálásának regionális relatív gyakoriságai az összes feldolgozott kandidémiás eset százalékában (Arendrup 2010). 